UNIVERSIDADE DE SÃO PAULO

FACULDADE DE ECONOMIA, ADMINISTRAÇÃO E CONTABILIDADE DEPARTAMENTO DE CONTABILIDADE E ATUÁRIA

PROGRAMA DE PÓS-GRADUAÇÃO EM CONTROLADORIA E CONTABILIDADE

\title{
MUDANÇAS REGULATÓRIAS NO MICROCRÉDITO E DESEMPENHO FINANCEIRO E SOCIAL DE COOPERATIVAS DE CRÉDITO NO BRASIL
}

Ana Lúcia Carvalho Santos

Orientador: Prof. Dr. Gerlando Augusto Sampaio Franco de Lima

Coorientador: Prof. Dr. Lucas Ayres Barreira de Campos Barros 
Dr. Marco Antonio Zago

Reitor da Universidade de São Paulo

Dr. Adalberto Américo Fischmann

Diretor da Faculdade de Economia, Administração e Contabilidade

Dr. Gerlando Augusto Sampaio Franco de Lima

Chefe do Departamento de Contabilidade e Atuária

Dr. Andson Braga de Aguiar

Coordenador do Programa de Pós-Graduação em Controladoria e Contabilidade 


\title{
ANA LÚCIA CARVALHO SANTOS
}

\section{MUDANÇAS REGULATÓRIAS NO MICROCRÉDITO E DESEMPENHO FINANCEIRO E SOCIAL DE COOPERATIVAS DE CRÉDITO NO BRASIL}

Tese apresentada ao Programa de PósGraduação em Controladoria e Contabilidade do Departamento de Contabilidade e Atuária da Faculdade de Economia, Administração e Contabilidade da Universidade de São Paulo, como requisito parcial para a obtenção do título de Doutor em Ciências.

Orientador: Prof. Dr. Gerlando Augusto Sampaio Franco de Lima

Coorientador: Prof. Dr. Lucas Ayres Barreira de Campos Barros

\author{
Versão Corrigida
}

(versão original disponível na Faculdade de Economia, Administração e Contabilidade)

SÃO PAULO

2016 
Autorizo a reprodução e divulgação total ou parcial deste trabalho, por qualquer meio convencional ou eletrônico, para fins de estudo e pesquisa, desde que citada a fonte.

FICHA CATALOGRÁFICA

Elaborada pela Seção de Processamento Técnico do SBD/FEA/USP

Santos, Ana Lúcia Carvalho

Mudanças regulatórias no microcrédito e desempenho financeiro e social de cooperativas de crédito no Brasil / Ana Lúcia Carvalho Santos. - São Paulo, 2016.

$189 \mathrm{p}$.

Tese (Doutorado) - Universidade de São Paulo, 2016.

Orientador: Gerlando Augusto Sampaio Franco de Lima.

Co-orientador: Lucas Ayres Barreira de Campos Barros.

1. Microfinanças 2. Contabilidade bancária 3. Políticas públicas 4. Cooperativas de crédito 5 . Indicadores de desempenho I. Universidade de São Paulo. Faculdade de Economia, Administração e Contabilidade. II. Título.

CDD - 332.742 
À minha mãe, Ana Macário; à minha filha, Ana Júlia.

Por elas e para elas. A todos aqueles que acreditam na transformação social, dedico. 



\section{AGRADECIMENTOS}

Agradeço a Deus, em primeiro lugar, por sempre conduzir minha vida de acordo com os Seus planos.

Aos meus orientadores e amigos, Prof. Dr. Gerlando Augusto Sampaio Franco de Lima e Prof. Dr. Lucas Ayres Barreira de Campos Barros por acreditarem em mim, por terem aceitado o desafio do tema e pela disponibilidade para ajudar. Sem as relevantes e oportunas críticas e sugestões de ambos, este trabalho não teria sido possível.

Ao Prof. Dr. Lauro Gonzalez e Prof. Dr. Bruno Salotti pelas valiosas contribuições no exame de qualificação. Ao Prof. Lauro, sou grata também pelas substanciais discussões e por intermediar o contato com o Ministério do Trabalho e Emprego (MTE) na difícil busca pelos dados.

Ao Prof. Dr. Gilberto Martins e Prof. Dr. Edgard Cornacchione pela motivação constantes e pelas contribuições em Seminário de Tese e Discussões Metodológicas. Ao Prof. Dr. Luiz Paulo Fávero, com quem tive a oportunidade de realizar a monitoria didática, quando então pude aprimorar minha prática docente.

Aos demais professores da Faculdade de Economia, Administração e Contabilidade (FEA)USP, em especial o professor Nelson Carvalho pelas contribuições relevantes e por intermediar o contato com o Sr. Sergio Darcy da Silva Alves, ex-diretor de Normas do Banco Central do Brasil (BCB). A este último, agradeço pelas importantes conversas e pela disponibilização de material para a pesquisa.

Ao Departamento de Estudos e Pesquisas (DEPEP) do BCB em São Paulo, especialmente ao Dr. Sérgio Mikio Koyama, chefe do DEPEP e a Dra. Raquel de Freitas Oliveira, pesquisadora do DEPEP, por viabilizarem o acesso à base de dados. A Tony Takeda, analista técnico do DEPEP, pela extração dos dados e pela grande ajuda na tabulação e realização dos testes estatísticos da pesquisa.

Ao MTE, principalmente a Sra. Lucilene Estevam Santana, Coordenadora- Geral de Emprego e Renda e o Sr. Antonio de Pádua Melo, Analista de Políticas Sociais, pela disponibilização dos dados.

Àqueles que auxiliaram nos contatos e/ou na realização das entrevistas principalmente José Nélio Corsini, do Centro de Apoio aos Pequenos Empreendedores (CEAPE)-Bahia, Jerônimo Ramos, da Santander Microcrédito e Marcia Fonseca, da Agência de Desenvolvimento do Estado da Bahia S.A. (Desenbahia).

A José Renato Sena Oliveira, a quem aprendi a chamar de amigo, pela leitura e correções do texto, pela formatação do trabalho e pelo apoio incondicional e incentivo durante todo o curso, sobretudo quando da realização do doutorado sanduíche na Universidade de Illinois, Estados Unidos, meus singelos agradecimentos.

À minha filha, Ana Júlia, por compreender que ficou "órfã" tanto tempo por uma boa causa, pelo apoio e amor ilimitados, por ser a razão de tudo, muito obrigada! À minha mãe, Ana Macário, por ser três vezes mãe de minha filha, por ser meu porto seguro, pelo apoio, carinho e aconchego de sempre. À Ana Mery, irmã e amiga, pela ajuda na coleta de dados e pelo apoio "logístico" com as demandas maternas que eu não conseguia atender. Sem vocês, eu não teria conseguido!

Às minhas irmãs Ana Maria e Ana Régia, meu pai, José, e meu irmão, Antonio (Jojó), meus sobrinhos Beatriz, Guilherme e Hiury, meu cunhado Joilson (meu motorista particular), pelo 
incentivo e torcida constantes. À minha família paulista, tias e primos, principalmente Tia Laide, pela acolhida. Às tias e primos de Vitória da Conquista, especialmente tia Maria e tia Luci, também sou grata.

À Iracema Raimunda Brito Neves Aragão, pela convivência nos "APs" e por compartilhar muitos momentos bons e outros não tão bons assim. A Robson Braga, pela amizade, preocupação e disponibilidade em ajudar. Aos demais "dinterianos" Márcia Figueredo D’Souza (Marcinha), Sandra Maria Cerqueira da Silva Mattos, Raimundo Nonato Lima Filho, Edmilson Patrocínio de Sousa e Emílio Maltez Alves Filho, pela convivência, troca de ideias e pelo aprendizado proporcionado.

Aos demais colegas do doutorado, em especial Eduardo Flores e Josué Braga, sempre presentes quando precisei, Mamadou Dieng, Bruna Camargos (Bruninha), Eduardo Alves, Cláudia Cruz, Claudio Zaro, Talles Brugni, André Carlos, Patrícia Romualdo, Carlos Kull, Diane Reina, Gisele Sterzeck, Raquel Sarquis, Verônica Santana, pelas enriquecedoras conversas e discussões na sala 15 e nos corredores.

Às companheiras do Laboratório de Finanças, Bianca Checon e Ludmila Melo, por todo apoio e ajuda. À Ludmila, agradeço também pela intermediação no MTE e à Universidade de Brasília (UnB), na busca pelos dados. Ao Prof. Dr. Danilo Marinho, da UnB, pelo envio das informações sobre o Programa Nacional de Microcrédito Produtivo Orientado (PNMPO).

Aos funcionários e colaboradores do Programa de Pós-graduação em Controladoria e Contabilidade (PPGCC), em especial Marcia Bento, Belinda Ludovici, Juliana Rodrigues e Gislaine Ferreira, além dos amigos Rodolfo Ferrari e Evandro Figueiredo, pela prontidão em nos atender e por tornar nossa vida na USP e em São Paulo bem mais fácil e agradável.

À Universidade Estadual de Feira de Santana, especialmente ao Prof. Dr. Rosembergue Valverde e a nossa querida Vilânia Silva, que não mediram esforços para que o Dinter fosse sucesso, meus sinceros agradecimentos.

Ao Prof. Dr. Werner Baer (in memoriam), por ter me recebido como Visiting scholar no The Lemann Institute for Brazilian Studies da University of Illinois at Urbana-Champaign (UIUC), em Urbana-Champaign, Estados Unidos viabilizando, assim, o desejado doutorado sanduíche. Sua receptividade e disposição em ajudar foram fundamentais para o enriquecimento da minha vivência enquanto pesquisadora e docente. Agradeço ainda a Profa. Dra. Mary Paula Arends-Kuenning, Diretora do Department of Agricultural and Consumer Economics e a Profa. Dra. Angela Christine Lyons (Angie), Diretora do Center for Economic and Financial Education no Department of Agricultural and Consumer Economics pelas ricas discussões acerca do tema da pesquisa. Não posso esquecer de Elis Artz e Gloria Ribble, Coordenadora e Gerente do Lemann Institute respectivamente, sempre solícitas e dispostas a ajudar. Com Elis e Angie construímos uma amizade que pretendo levar adiante.

À amiga que ganhei em São Paulo, Val Bercon, pelo apoio, pelas correções do texto e por me mostrar que existe amor em Sampa. À amiga Miriam Maretti, que mesmo distante fisicamente sempre esteve do meu lado me apoiando e incentivando.

Enfim, minha gratidão a todas e todos que direta e indiretamente contribuíram com a construção deste trabalho, os quais por puro esquecimento, possa ter omitido. 
"Sonho que se sonha só é só um sonho que se sonha só mas, sonho que se sonha junto é realidade" Raul Seixas, compositor baiano 



\section{RESUMO}

Santos, A. L. C. (2016). Mudanças regulatórias no microcrédito e desempenho financeiro e social de cooperativas de crédito no Brasil. Tese de Doutorado, Faculdade de Economia, Administração e Contabilidade, Universidade de São Paulo, São Paulo.

Este estudo analisa as mudanças regulatórias no microcrédito e os seus efeitos no desempenho financeiro e social de cooperativas de crédito no Brasil. Temas como microfinanças e microcrédito são amplamente explorados nas últimas décadas tanto internacionalmente como no Brasil assim como o cooperativismo de crédito e o seu respectivo desempenho têm fomentado relevantes estudos. O microcrédito no Brasil é concebido no contexto das políticas públicas, notadamente os programas Programa Nacional de Microcrédito Produtivo Orientado (PNMPO) e o CRESCER programa nacional de microcrédito, os quais são considerados como uma política pública social implementada via mercado financeiro. As mudanças regulatórias ocorridas no microcrédito em 2011 impactaram todas as instituições ofertantes de microcrédito de maneiras e magnitudes diferentes. A avaliação de desempenho de instituições de microcrédito, mais especificamente das cooperativas de crédito, explorada nesta tese, baseia-se em indicadores de desempenho financeiro e social. A estratégia metodológica adotada é o experimento "natural" ou "quasi" experimento com suporte da técnica estatística diferenças em diferenças. A população corresponde a 1.429 cooperativas observadas durante 14 semestres. O período estudado é 2008 a 2014. Os dados são coletados em duas fontes: no Banco Central do Brasil, que disponibiliza dados inéditos do Plano Contábil das Instituições do Sistema Financeiro Nacional (COSIF) e do Sistema de Informações de Crédito (SCR), e no Ministério do Trabalho e Emprego (MTE), via coordenação do PNMPO, além de entrevistas realizadas com agentes qualificados nas instituições concedentes de microcrédito. Os resultados indicam que a oferta de microcrédito produtivo e orientado cresceu substancialmente sobretudo pelos bancos públicos, que tinham metas a serem cumpridas até o final de 2013. Assim, o programa CRESCER cumpriu o objetivo da massificação do microcrédito, entretanto, a despeito do crescimento considerável da oferta, esta ainda é pouco representativa em relação ao total de crédito ofertado pelas instituições em geral. Quanto às cooperativas de crédito os resultados das regressões, que se referem ao efeito da intervenção, revelam que as mudanças regulatórias não exerceram grande influência nos indicadores de desempenho financeiro e social das cooperativas que concedem esse tipo de crédito, principalmente nos indicadores financeiros. Nos indicadores sociais, os resultados apontam que as mudanças foram mais eficazes para estimular a amplitude do que a profundidade do alcance. Por fim, cabe salientar que as inferências devem ser feitas com cautela, visto que o pressuposto de tendências paralelas não está garantido e o tratamento não é totalmente exógeno. Os achados desta pesquisa podem ser úteis para todos os que se interessam por microfinanças, microcrédito e cooperativismo de crédito desde os gestores das instituições até os policy makers, acadêmicos, pesquisadores e também os beneficiários do microcrédito.

Palavras-chave: Microfinanças. Contabilidade bancária. Políticas públicas. Cooperativas de crédito. Indicadores de desempenho. 


\begin{abstract}
Santos, A. L. C. (2016). Regulatory changes on microcredit and financial and social performances of Brazilian credit unions. 181p. PhD dissertation. School of Economics, Business and Accounting. University of São Paulo, São Paulo.
\end{abstract}

This study investigates regulatory changes on microcredit and its impacts on financial and social performances of Brazilian credit unions. Subjects such as microfinance and microcredit are being largely explored on the last decades internationally as well as in Brazil, and relevant studies are being promoted on credit union and its respective performance too. Microcredit in Brazil is conceived on a public policy context, mainly when considering National Program of Productive and Oriented Microcredit (PNMPO, initials in Portuguese) and National Program of Microcredit CRESCER, which are considered as public policies implemented through financial market. The regulatory chances which have happened on microcredit at 2011 have influenced all microcredit institutions, but not in the same way or magnitude. The performance evaluation of microcredit institutions (more specifically, the credit unions) which is explored on this dissertation is based on financial and social performance indexes. The strategy adopted to analyze it is "natural" experiment, or "quasi" experiment, using difference-in-differences as statistical technique. The study population totalizes 1,429 Credit Unions per semester. The period of analysis is from 2008 to 2014. The data was gathered in two main sources: on Central Bank of Brazil (which has made available inedited data about the Accounting Plan for Institutions on National Financial System - COSIF, initials in Portuguese - and System of Credit Information - SCR, initials in Portuguese) and on Ministry of Job and Employment - MTE, initials in Portuguese (through PNMPO coordination), and also by interviews made with qualified agents on microcredit institutions. The results indicate that productive and oriented microcredit supply has increased substantially on public banks, which had goals to be achieved until the end of 2013. Therefore, CRESCER program has accomplished credit massification; however, even with this significant increase on supply, it is still scarcely representative when considering all credit offered by general institutions. About credit unions, regressions results about intervention impact has shown that regulatory chances have not exerted a big influence on financial and social performance indexes of cooperatives that offer this kind of credit, mostly on financial indexes. About social indexes, results have indicated that changes were more effective to stimulate breadth rather than depth of outreach. To conclude, it is important to say that all inferences must be made with caution, whereas parallel tendency is not guaranteed and the treatment is not completely exogenous. Findings of this research may be useful to all of those who are interested on microfinance, microcredit and credit union, since those institutions managers until policy makers, academics, social scientists and microcredit beneficiaries.

Key words: Microfinance. Banking accounting. Public policies. Credit unions. Performance indexes. 


\section{LISTA DE FIGURAS}

Figura 1: Diferenças conceituais entre microfinanças, microcrédito e microcrédito produtivo e orientado.

Figura 2: Quadro Principais características organizacionais das Instituições de Microfinanças (IMFs) brasileiras.

Figura 3: Quadro Síntese dos Estudos sobre Regulação de Microfinanças e Microcrédito....55

Figura 4: Quadro Síntese de Decretos, Resoluções e Leis. .....................................................60

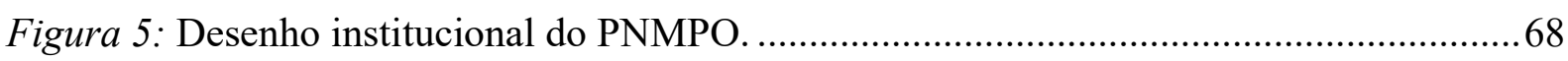

Figura 6: PNMPO - Resultados consolidados anuais em número de operações (em unidades) $-2005-2014$.

Figura 7: PNMPO - Resultados consolidados Carteira Ativa por Constituição Jurídica - Valor

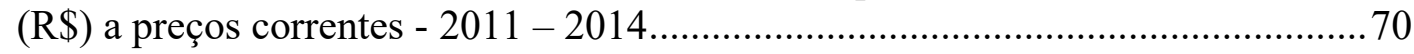

Figura 8: Quadro Características do PNMPO/CRESCER .................................................. 75

Figura 9: Programa CRESCER - Valor contratado por ano* (R\$) a preços correntes - 2012 -

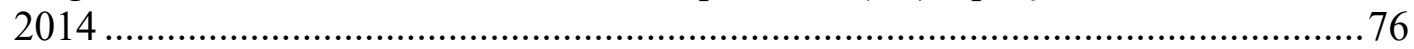

Figura 10: Programa CRESCER - Número de operações por ano* (R\$) a preços correntes $2012-2014$

Figura 11: PNMPO - Execução pelos Bancos Públicos Federais - Recursos emprestados (em $\mathrm{R} \$$ a preços correntes) $-2012-2014$.

Figura 12: PNMPO - Execução pelos Bancos Públicos Federais - Número de contratos realizados $-2012-2014$.

Figura 13: PNMPO - Execução pelos Bancos Públicos Federais - Número de clientes atendidos $-2012-2014$.

Figura 14: PNMPO - Execução pelas OSCIPs - Recursos emprestados (em R $\$$ a preços correntes) $-2012-2014$.

Figura 15: Quadro Síntese dos Estudos sobre Desempenho de Instituições de Microfinanças.

Figura 16: Estrutura conceitual e operacional da relação entre as variáveis do estudo. 105

Figura 17: Participação relativa por linhas de crédito dos recursos direcionados, em \% dez/2007 a de/2014

Figura 18: Participação das submodalidades de crédito no total de operações - Cooperativas de Crédito (\%)

Figura 19: Quantidade de instituições financeiras que ofertam microcrédito por segmento. 113

Figura 20: Microcrédito - Valor da carteira total em \% por instituição financeira.

Figura 21: Saldo dos contratos ativos, Quantidade de contratos ativos e Número de clientes ativos - 2008 a 2014 (dados trimestrais)

Figura 22: Saldo dos contratos realizados, Quantidade de contratos realizados e Número de contratos realizados por cliente - 2008 a 2014 (dados trimestrais). 
Figura 23: Valor da Carteira Ativa por tipo de Instituição (em R \$ milhões) - dados trimestrais- 2008 a 2014.

Figura 24: Valor da Carteira Ativa por tipo de Instituição (em R \$ milhões) - dados trimestrais-2008 a 2014, exceto bancos públicos

Figura 25: Evolução média do indicador Margem de intermediação financeira (MARG_FIN).

Figura 26: Diferença média de crescimento no indicador financeiro margem de intermediação financeira (MARG_FIN) entre os grupos de controle e de tratamento - intervalo de confiança a $95 \%$.

Figura 27: Valor total dos contratos ativos (em R\$ bilhões) - 2008 a 2014 (dados trimestrais)

Figura 28: Quantidade de contratos ativos (em milhões) - 2008 a 2014 (dados trimestrais) 181

Figura 29: Quantidade de clientes ativos (em R \$ milhões) - 2008 a 2014 (dados trimestrais)

Figura 30: Valor total dos contratos realizados (em R \$ bilhões) - 2008 a 2014 (dados trimestrais)

Figura 31: Quantidade de contratos realizados (em milhões) - 2008 a 2014 (dados trimestrais)

Figura 32: Quantidade de contratos realizados por clientes (em R\$ milhões) - 2008 a 2014 (dados trimestrais)

Figura 33: Valor dos contratos ativos bancos públicos - 2008 a 2014 (dados trimestrais) - em $\mathrm{R} \$$ milhões

Figura 34: Valor da Carteira Ativa - Cooperativas de Crédito (em R\$ milhões) - dados trimestrais

Figura 35: Valor da Carteira Ativa - OSCIPs (em R\$ milhões) - dados trimestrais- 2008 a 2014 


\section{LISTA DE TABELAS}

Tabela 1: Evolução do quantitativo de instituições habilitadas pelo MTE a operar no âmbito do PNMPO - 2005-2015.

Tabela 2: Variáveis de mensuração de desempenho financeiro e social 106

Tabela 3: Evolução do quantitativo de instituições financeiras autorizadas ${ }^{3}$ pelo BCB, por segmento - 2008 a 2014

Tabela 4: Participação percentual dos diversos segmentos do SFN nos ativos totais do sistema - 2010 a 2014

Tabela 5: Evolução do Patrimônio Líquido, Ativos, Depósitos e Operações de Crédito ${ }^{1}$ das Cooperativas de Crédito - 2010 a 2014 - em $R \$$ bilhões

Tabela 6: Evolução do quantitativo de instituições habilitadas pelo MTE a operar no âmbito do PNMPO (2005-2015)

Tabela 7: Evolução do número de cooperativas habilitadas no MTE

Tabela 8: Modalidades de crédito ofertadas pelas cooperativas por grupo (de tratamento e de controle) 136

Tabela 9: Evolução do microcrédito - dez/2008 - dez/2014......

Tabela 10: Estatística descritiva das variáveis

Tabela 11: Estatística descritiva das variáveis antes e após as mudanças regulatórias no microcrédito (201112) - Grupo de Tratamento (Cooperativas que fazem microcrédito)

Tabela 12: Estatística descritiva das variáveis antes e após as mudanças regulatórias no microcrédito (201112) - Grupo de Controle (Cooperativas que não fazem microcrédito)

Tabela 13: Regressões sem controles - Indicadores Financeiros

Tabela 14: Regressões controlando pela carteira ativa total (LCAT) - Indicadores Financeiros.

Tabela 15: Regressões controlando pela interação entre a carteira ativa total (LCAT) e as dummies de tempo - Indicadores Financeiros ..................................................... 150

Tabela 16: Regressões sem controles - Indicadores sociais

Tabela 17: Regressões controlando pela carteira ativa total (LCAT) - Indicadores sociais 153

Tabela 18: Regressões controlando pela interação entre a carteira ativa total (LCAT) e as dummies de tempo - Indicadores sociais ..... 



\section{LISTA DE ABREVIATURAS E SIGLAS}

AGI Agentes de Intermediação

ASCOOB Associação das Cooperativas de Apoio à Economia Familiar

BCB Banco Central do Brasil

BB Banco do Brasil

BID Banco Interamericano de Desenvolvimento

BIRD Banco Internacional para Reconstrução e Desenvolvimento

BNDES Banco Nacional de Desenvolvimento Econômico e Social

CEAPE Centro de Apoio aos Pequenos Empreendimentos

CEBDS Conselho Empresarial Brasileiro para o Desenvolvimento Sustentável

CEF Caixa Econômica Federal

CFC Conselho Federal de Contabilidade

CFSP Consortium on Financial Systems and Poverty

CGAP Consultative Group to Assist the Poor

CMN Conselho Monetário Nacional

CPC Comitê de Pronunciamentos Técnicos

CODEFAT Conselho Deliberativo do FAT

COSIF Plano Contábil das Instituições do Sistema Financeiro Nacional

CRESCER Programa Nacional de Microcrédito

CRESOL Sistema de Cooperativas de Crédito Rural Solidário

DEPEP Departamento de Estudos e Pesquisas

CVM Comissão de Valores Mobiliários

DEA Data Envelopment Analysis

DESUC Departamento de Supervisão de Cooperativas e de Instituições Não Bancárias

DGRV Deutsche Genossenschafts- und Raiffeisenverband e.V.

DIM Depósitos Interfinanceiros Vinculados a Operações de Microfinanças

FAT Fundo de Amparo ao Trabalhador

FHC Fernando Henrique Cardoso

IAF Inter American Foundation

IASB International Accounting Standards Board

IBGE Instituto Brasileiro de Geografia e Estatística

ICSID International Centre for Settlement of Investment Disputes

IDA International Development Association

IF Instituição Financeira 


\begin{tabular}{|c|c|}
\hline IFC & International Finance Corporation \\
\hline IFNB & Instituições Financeiras não Bancárias \\
\hline IFO & Instituições Financeiras Operadoras \\
\hline IMC & Instituições de Microcrédito \\
\hline IMF & Instituições de Microfinanças \\
\hline IMPO & Instituições de Microcrédito Produtivo Orientado \\
\hline INEC & Instituto Nordeste Cidadania \\
\hline IPCA & Índice de Preços ao Consumidor Amplo \\
\hline ISM & Indicador de Desempenho Social de Instituições de Microfinanças \\
\hline MDS & Ministério do Desenvolvimento Social \\
\hline MIGA & Multilateral Investment Guarantee Agency \\
\hline MIX & Microfinance Information eXchange \\
\hline MPO & Microcrédito Produtivo e Orientado \\
\hline MQO & Mínimos Quadrados Ordinário \\
\hline MTE & Ministério do Trabalho e Emprego \\
\hline NCUA & National Credit Union Administration \\
\hline NEI & Nova Economia Institucional \\
\hline OLS & Ordinary Least Squares \\
\hline ONG & Organizações Não Governamentais \\
\hline ONU & Organização das Nações Unidas \\
\hline OSCIP & Organizações da Sociedade Civil de Interesse Público \\
\hline PCPP & Programa de Crédito Produtivo e Popular \\
\hline PDI & Programa de Desenvolvimento Institucional \\
\hline PIB & Produto Interno Bruto \\
\hline PNMPO & Programa Nacional de Microcrédito Produtivo Orientado \\
\hline PROGER & Programa de Geração de Emprego e Renda \\
\hline PRONAF & Programa Nacional de Fortalecimento da Agricultura Familiar \\
\hline $\mathrm{SCC}$ & Sistema de Crédito Cooperativo \\
\hline SCMEPP & Sociedades de Crédito ao Microempreendedor e a Empresas de Pequeno Porte \\
\hline SCM & Sociedades de Crédito ao Microempreendedor \\
\hline SCR & Sistema de Informações de Crédito \\
\hline SFN & Sistema Financeiro Nacional \\
\hline SINE & Sistema Nacional de Emprego \\
\hline SPE & Secretaria de Política Econômica \\
\hline SPTF & Social Performance Task Force \\
\hline
\end{tabular}


SUSEP Superintendência de Seguros Privados

TAC Taxa de Abertura de Crédito

UNICEF Fundo das Nações Unidas para a Infância

UNO União Nordeste de Assistência a Pequenas Organizações

WOCCU World Council of Credit Unions 



\section{SUMÁRIO}

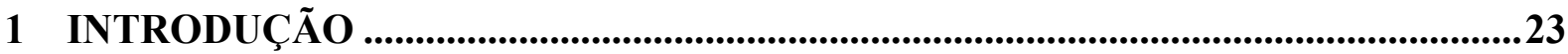

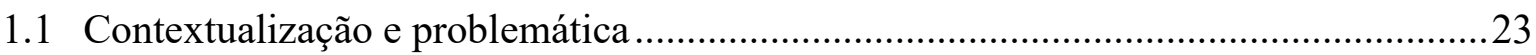

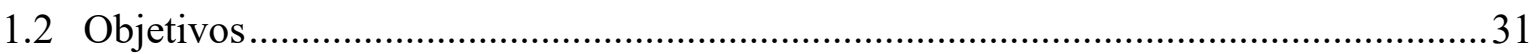

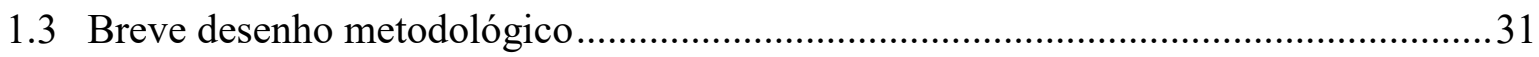

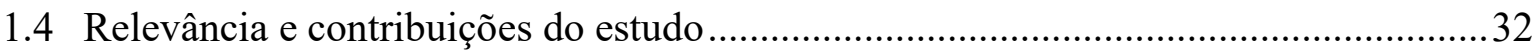

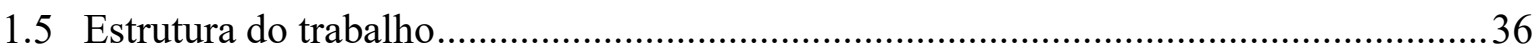

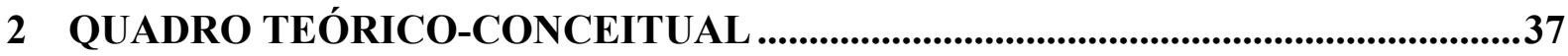

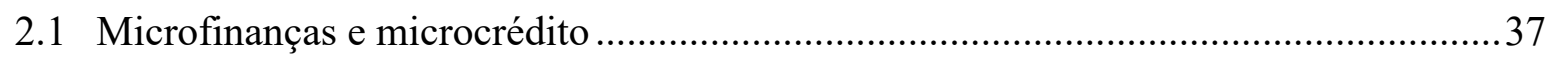

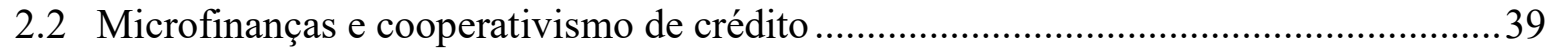

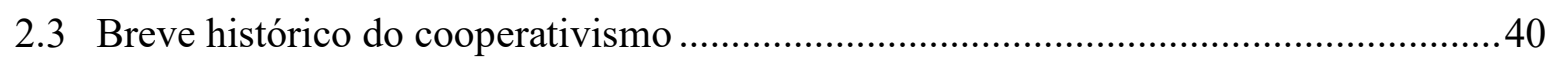

2.4 Cooperativas de crédito: definição e classificação ......................................................4 41

2.5 Cooperativismo de crédito solidário ........................................................................43

2.6 A Nova Economia Institucional e as Instituições de Microfinanças ............................44

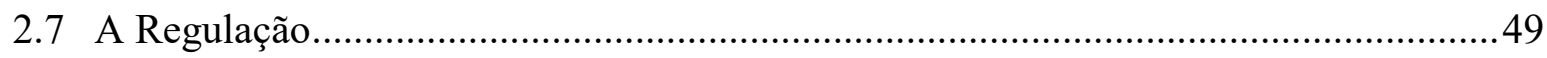

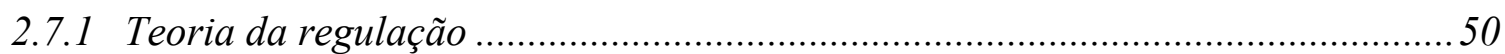

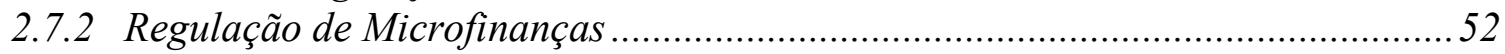

2.7.3 Regulação das Microfinanças e do Microcrédito no Brasil.....................................56

2.8 Microfinanças e microcrédito no contexto das políticas de financiamento do

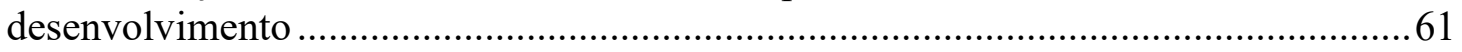

2.8.1 As Politicas de microfinanças e de microcrédito no Brasil ...................................63 63

2.8.2 O Programa Nacional de Microcrédito Produtivo Orientado (PNMPO) e o CRESCER - Programa Nacional de Microcrédito ........................................................ 67

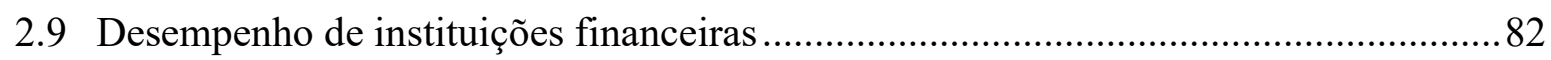

2.10 Desempenho de Instituições Microfinanceiras (IMFs) .................................................. 84

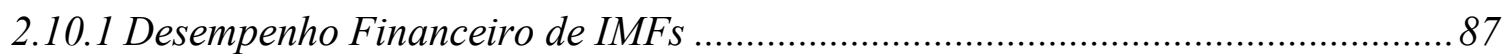

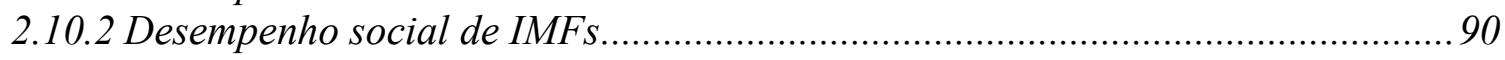

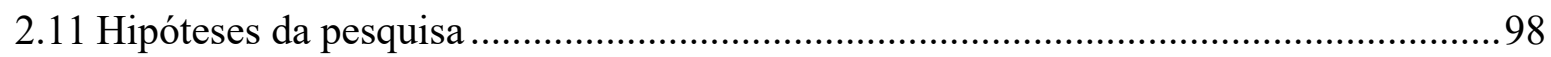

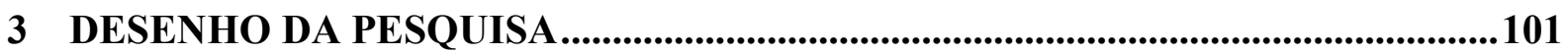

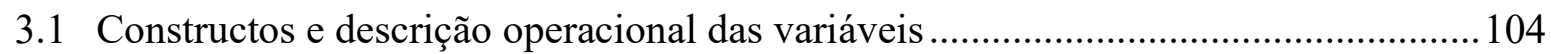

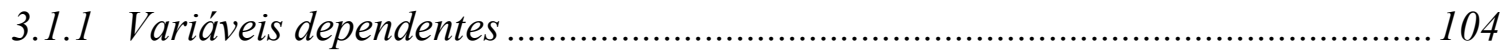

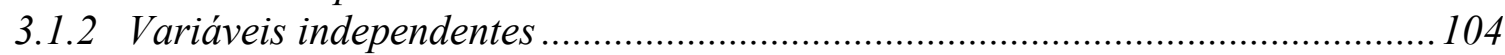

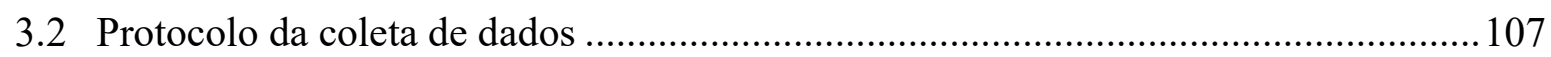

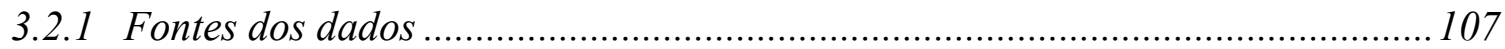

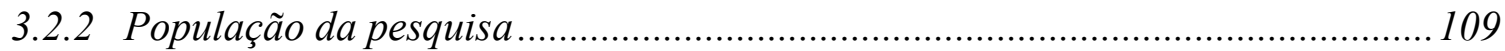

3.2.3 Observações a respeito das diferenças metodológicas e conceituais das bases de

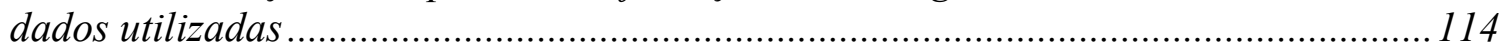

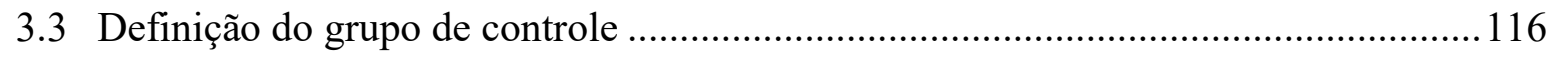

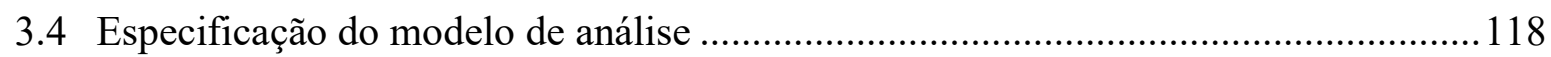

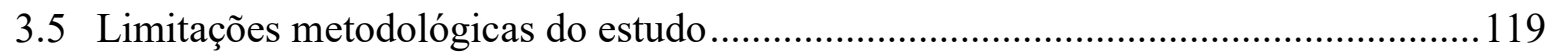

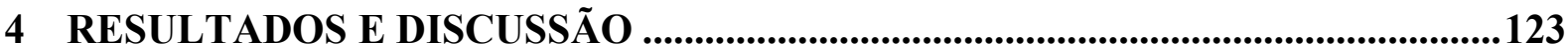




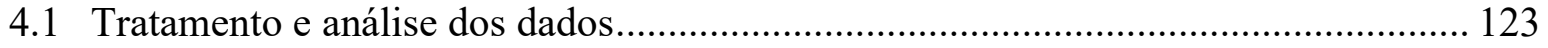

4.2 Caracterização da população (grupo de tratamento x grupo de controle)................... 133

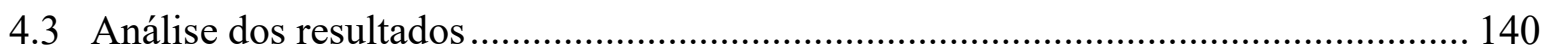

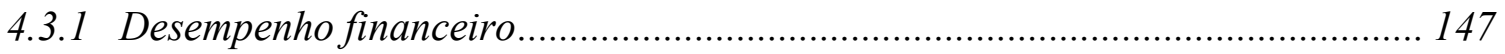

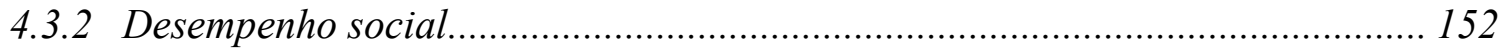

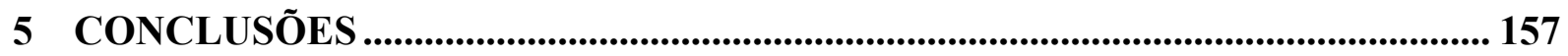

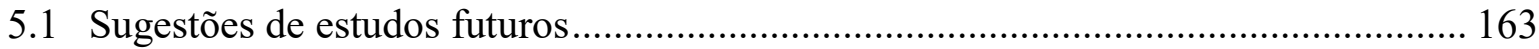

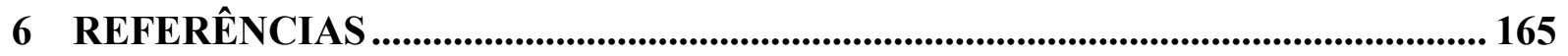

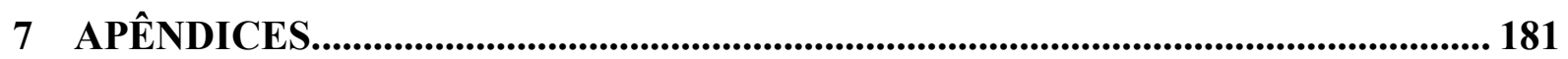

7.1 APÊNDICE A: Valor total dos contratos ativos (em R\$ bilhões) - 2008 a 2014 (dados trimestrais).

7.2 APÊNDICE B: Quantidade de contratos ativos (em milhões) - 2008 a 2014 (dados

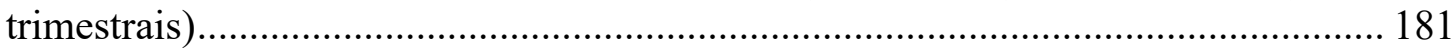

7.3 APÊNDICE C: Quantidade de clientes ativos (em R\$ milhões) - 2008 a 2014 (dados trimestrais).

7.4 APÊNDICE D: Valor total dos contratos realizados (em R\$ bilhões) - 2008 a 2014

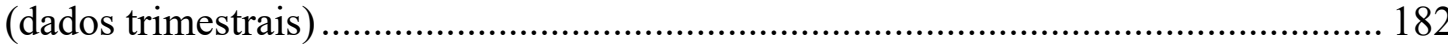

7.5 APÊNDICE E: Quantidade de contratos realizados (em milhões) - 2008 a 2014 (dados

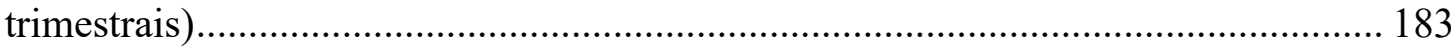

7.6 APÊNDICE F: Quantidade de contratos realizados por clientes (em R \$ milhões) 2008 a 2014 (dados trimestrais) ............................................................................... 183

7.7 APÊNDICE G: Valor dos contratos ativos - Bancos públicos - 2008 a 2014 (dados trimestrais) - em R \$ milhões .............................................................................. 184

7.8 APÊNDICE H: Valor da Carteira Ativa - Cooperativas de Crédito (em R\$ milhões) -

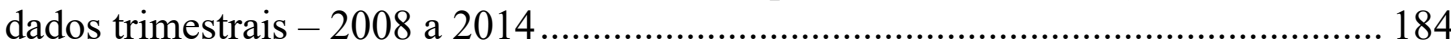

7.9 APÊNDICE I: Valor da Carteira Ativa - OSCIPs (em R \$ milhões) - dados trimestrais-

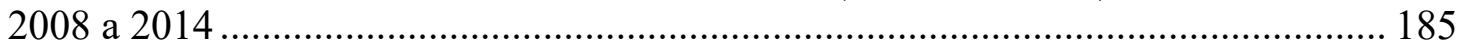

7.10 APÊNDICE J: Termo de Consentimento Livre e Esclarecido (TCLE) ..................... 187

7. 11 APÊNDICE K: Roteiro de Entrevista ................................................................ 188 


\section{INTRODUÇÃO}

\subsection{Contextualização e problemática}

Em seu discurso quando do recebimento do Nobel da Paz em 2006, Yunus (2010) conta que a ideia de conceder empréstimos aos pobres surgiu quando ele conheceu uma mulher de 21 anos, a qual em 1974 sustentava sozinha seus três filhos na aldeia de Jobra em Bangladesh. Para isso, ela produzia tamboretes de bambu com recursos emprestados de um agiota sob a condição de vender toda a sua produção exclusivamente ao financiador a preços fixados por ele. O uso do termo microcrédito é atribuído a este autor que o compreende como um instrumento de combate à pobreza e se refere ao crédito direcionado às populações pobres ou muito pobres, caracterizadas pela falta de acesso ao mercado de crédito convencional.

Embora o microcrédito já fosse ofertado pelas cooperativas de crédito desde o século XIX, a concepção moderna de microcrédito é atribuída à experiência do Grameen Bank, criado por Yunus (2010) em Bangladesh, em 1976. O microcrédito está inserido em um conceito ainda mais atual e abrangente que é a abordagem das microfinanças. Microfinanças, por sua vez, são todos os serviços financeiros como empréstimos, poupança, seguros, cartões de crédito e outros, destinados à população de baixa renda, e o microcrédito se constitui como o principal serviço das microfinanças (Barone \& Sader, 2008).

Temas como microfinanças e microcrédito têm sido explorados por diversas áreas de conhecimento, notadamente, as ciências sociais aplicadas em que se insere a Contabilidade. Do mesmo modo, o cooperativismo de crédito e sua participação na indústria de microfinanças têm fomentado alguns debates e estudos (Gaboury \& Quirion, 2006; Railienè \& Sinevičienè, 2015; Rock, Otero \& Saltzman, 1998; Ward \& McKillop, 2005). Labie \& Périlleux (2008) ao falarem do significativo crescimento das microfinanças em todo o mundo chamam a atenção para a participação das cooperativas de crédito, especialmente em países da África, Ásia e América Latina. Para os autores, a relevância destas instituições para as microfinanças é cada vez mais reconhecida por acadêmicos e pelos demais atores da indústria de microfinanças.

A contabilidade financeira objetiva viabilizar aos usuários externos a avaliação da situação econômica e financeira da entidade. Assim, a avaliação do desempenho de instituições de microcrédito, mais especificamente das cooperativas de crédito, explorada nesta tese, está contemplada pelo escopo dessa área de conhecimento. Em verdade, o estudo desenvolvido se insere mais especificamente no âmbito da Contabilidade bancária, cujo 
processo de divulgação contábil é realizado por meio do Plano Contábil das Instituições do Sistema Financeiro (COSIF) tendo em vista que os indicadores contábeis utilizados nesta pesquisa são produzidos a partir desta base.

As discussões acerca de microfinanças e microcrédito ganharam notoriedade mundial com a criação do Grameen Bank. No Brasil, a União Nordeste de Assistência a Pequenas Organizações (UNO), foi quem iniciou as primeiras experiências de microcrédito no país, em 1973. Assim, é principalmente a partir da década de 1990, que as ações, políticas e programas direcionados às microfinanças e ao microcrédito se intensificam no Brasil, e essas políticas e programas têm enfatizado o microcrédito produtivo (Barone \& Sader, 2008). Para estes autores, microcrédito produtivo é aquele direcionado aos micro e pequenos empreendimentos formais e informais e, em princípio, não se destina a financiar o consumo. Dentre as ações destinadas ao fomento deste tipo de crédito no Brasil, destaca-se o Programa Nacional de Microcrédito Produtivo Orientado (PNMPO), criado em 2005 e revisado em 2011, considerado uma das mais importantes iniciativas relacionadas à regulamentação do microcrédito no Brasil. Em agosto de 2011, o PNMPO foi reestruturado sendo então criado o CRESCER - Programa Nacional de Microcrédito, ambos objeto de estudo da presente pesquisa.

Com o crescimento das experiências e inciativas voltadas para as microfinanças e o microcrédito, crescem sobremaneira os estudos relacionados ao tema. No Brasil, os estudos sobre microfinanças e microcrédito têm várias dimensões: (a) avaliação de programas específicos, a exemplo do Crediamigo, do Banco do Nordeste do Brasil (Braga, 2011; Neri \& Medrado, 2010); (b) sustentabilidade das Instituições de Microcrédito (Faxine, 2005; Lesmam \& Carmona, 2008). O presente estudo insere-se nesta última abordagem, uma vez que trata da análise dos efeitos de mudanças regulatórias no desempenho de cooperativas de crédito.

Em geral a sustentabilidade é considerada em dois níveis: um operacional e outro financeiro. A sustentabilidade operacional refere-se à capacidade das instituições de gerar receita suficiente para cobrir os custos operacionais (não necessariamente o custo total do capital) e a sustentabilidade financeira é definida como a capacidade da instituição se autos sustentar sem depender de subsídios (Morduch, 1999). Os estudos relacionados à sustentabilidade de instituições de microfinanças tratam, principalmente, de um possível trade-off entre a sustentabilidade das instituições e o alcance aos pobres ou entre os desempenhos financeiro e social (Araújo, 2012; Bédécarrats et al., 2011; Borba, 2012; Foose \& Greenberg, 2008; Frank, 2008; Gonzalez, 2010; Gonzalez, 2010a; Kai, 2009; Kumar Kar, 2011; Sinha, 2006; Sinha \& Brar, 2005; Tulchin, 2004). 
Instituições de Microcrédito (IMCs), por excelência, são organizações que possuem múltiplos objetivos: sustentabilidade financeira, impacto econômico e social sobre os clientes e na comunidade e até mesmo a proteção ao meio ambiente. As cooperativas de crédito estão entre elas. Estudos mais recentes (Bédécarrats, Bastiaensen \& Doligez, 2013; Bédécarrats, Baur \& Lapenu, 2011; Borba, 2012; Hermes \& Meesters, 2011; Kumar Kar, 2011; Mersland \& Urgeghe, 2011; Servin, Lensink, \& Van den Berg, 2012) têm debatido um provável tradeoff entre os objetivos e, consequentemente, o desempenho financeiro e social deste tipo de instituição. No segmento de microfinanças, diversas organizações, a exemplo da Microfinance Information Exchange ( $\left.\mathrm{MIX}^{1}\right)$, Consultative Group to Assist the Poor ( $\left.\mathrm{CGAP}^{2}\right)$ e Comité d'Echanges de Réflexion et d'Information sur les Systèmes d'Epargne-crédit $\left(\right.$ CERISE $\left.^{3}\right)$ vêm compartilhando experiências e desenvolvendo estudos em torno da elaboração de métricas para a mensuração do desempenho de IMCs. A questão do desempenho social é mais complexa e possui indicadores ainda não consolidados. Os mais desenvolvidos e utilizados são os sintetizados e divulgados na plataforma MIX e que serviram de referência para este estudo.

Quanto à regulação, existem diversas concepções e significados para o termo. Em Economia, por exemplo, trata-se da intervenção do Estado ou de outras autoridades legítimas na elaboração e coordenação de ações e políticas. Na Contabilidade, Laughlin (2007) faz uma distinção entre regulação da contabilidade (accounting regulation) e regulação contábil (regulation of accounting). A regulação da contabilidade é realizada por entes normativos externos como Comissão de Valores Mobiliários (CVM), Conselho Federal de Contabilidade (CFC), Comitê de Pronunciamentos Contábeis (CPC), International Accounting Standards Board (IASB), Banco Central do Brasil (BCB), dentre outros, e a regulação contábil é interna à contabilidade, ou seja, é a reação dos contabilistas e das firmas à regulação da contabilidade. $\mathrm{Na}$ abordagem da sociologia política, a regulação confere ao Estado o papel de definir, coordenar e executar as políticas e ações públicas, porém este partilha esse papel com outros atores sociais como as empresas e a sociedade civil organizada. Em outras palavras, a concepção contemporânea de política pública refere-se à intervenção do Estado na economia com participação social. As análises realizadas neste estudo baseiam-se nesta última abordagem, por considerar-se que a política pública é a instrumentalização da regulação dado

\footnotetext{
${ }^{1}$ Organização sem fins lucrativos, fundada pelo $C G A P$ e ligada ao Banco Mundial.

${ }^{2}$ Grupo Consultivo de Ajuda à População Pobre também vinculada ao Banco Mundial.

${ }^{3}$ Associação sem fins lucrativos que promove as finanças éticas e responsáveis e negócios sociais, criada em 1998 e com sede em Paris. Trabalha de maneira colaborativa com estudos e pesquisas além de capacitar e acompanhar a realização de auditorias sociais. Para mais informações, consulte http://www.cerisemicrofinance.org.
} 
que o objetivo de qualquer política pública, seja econômica ou social, é incentivar ou desincentivar algum segmento específico da sociedade.

De maneira geral, a regulação surge das externalidades que ocorrem no mercado, tanto as positivas (sistema de pagamentos, multiplicador monetário) como as negativas (riscos). As externalidades negativas mais discutidas no mercado financeiro, especificamente no mercado de crédito, são o risco sistêmico e o risco moral. O risco sistêmico ocorre quando problemas em uma instituição impactam as demais, pondo em risco todo o sistema financeiro. Já o risco moral é um conceito mais complexo e decorre das imperfeições do mercado de crédito, mais especificamente da assimetria informacional (Stiglitz, 1989; Stiglitz \& Weiss, 1981).

Para os economistas neoclássicos que consideram os pressupostos do mercado perfeito, no mercado de crédito, tal qual nos demais, seria possível haver equilíbrio entre oferta e demanda e a taxa de juros teria no mercado financeiro o mesmo papel que o preço tem no mercado produtivo (de bens e serviços): seria a responsável por esse equilíbrio. Em outras palavras, no caso de haver um excesso de demanda por crédito, por exemplo, no curto prazo, a taxa de juros subiria até o ponto em que o equilíbrio entre a oferta e a demanda se igualaria, ou seja, o equilíbrio se restabeleceria. No caso de excesso de oferta, ocorreria o inverso. Acontece que o mercado, de maneira generalizada, possui falhas (imperfeições) e no mercado de crédito especificamente, essas imperfeições podem levar à seleção adversa e ao risco moral.

As imperfeições do mercado financeiro foram analisadas por Stiglitz (1989), o qual explicou que, em decorrência das informações imperfeitas, as instituições financeiras são fortemente tentadas a racionar o crédito, mesmo havendo uma alta demanda. Sendo assim, de acordo com o modelo de Stiglitz (1989), a taxa de juros de equilíbrio é a que maximiza o retorno esperado do emprestador, a despeito do excesso de demanda por crédito. A hipótese básica desse modelo é que a imperfeição das informações no mercado de crédito não permite que as instituições ofertantes diferenciem os bons dos maus pagadores e, assim sendo, não teriam como selecionar os bons projetos a serem financiados. As instituições então tomariam a taxa de juros como um indicador dos bons e dos maus tomadores: os bons não estariam dispostos a pagar uma alta taxa de juros pelo risco de a inadimplência ser também alta e o contrário também ocorreria. Portanto, para o autor, taxa de juros e qualidade dos emprestadores são inversamente proporcionais: quanto mais elevadas as taxas de juros, menor a qualidade média dos tomadores de empréstimos. Esse fenômeno ficou conhecido na literatura da economia da informação como seleção adversa. A seleção adversa, segundo Akerlof (1970), decorre da associação entre informação assimétrica e queda da qualidade 
média dos bens e serviços comercializados no mercado de bens e serviços. O modelo de Akerlof (1970) demonstra de que forma o problema de seleção adversa devido à assimetria informacional pode levar à ineficiência dos mercados em geral.

No mercado de crédito a seleção adversa se refere ao desconhecimento do emprestador a respeito de tudo o que envolve o tomador e o contrato antes de sua realização e o risco moral corresponde à falta de informação do emprestador sobre as futuras ações do tomador após a concessão do empréstimo. Conforme Stiglitz e Weiss (1981), a assimetria de informações pode distorcer os preços praticados no mercado de crédito, no caso a taxa de juros, fazendo com que o equilíbrio não seja alcançado quando a oferta e a demanda por crédito se igualarem. Isto ocorre porque, se a instituição ofertante do crédito aumentar a taxa de juros quando a demanda por credito for maior que a oferta, essa taxa de juros elevada não necessariamente irá atrair os tomadores mais adimplentes, pelo contrário, a probabilidade desse tipo de tomador tornar-se inadimplente é maior. Em relação ao risco moral, para os autores, o tomador nem sempre desenvolve o comportamento esperado pelo emprestador. Em outras palavras, o tomador pode não administrar bem os recursos e culminar na incapacidade de honrar o que foi estabelecido em contrato, seja em relação ao pagamento, seja à pontualidade. Enquanto a seleção adversa ocorre ex-ante a um contrato ou um financiamento, o risco moral se dá ex-post (Stiglitz e Weiss, 1981).

Uma das consequências dessas falhas no mercado de crédito (seleção adversa e risco moral) é que as instituições financeiras aumentam as garantias exigidas, tornando os pobres e os pequenos empreendedores inabilitados para o crédito ofertado pelas instituições tradicionais por não disporem de garantias reais (ativos regularizados, renda comprovada etc.). Neste contexto, o empréstimo em grupo é apontado como uma forma de mitigar o problema da falta ou insuficiência do colateral dos pobres e dos micro e pequenos empreendimentos (Aghion \& Morduch, 2005; Conning, 1996; Morduch, 1999; Stiglitz, 1993). Morduch (1999) considera o empréstimo em grupo como uma das principais inovações do microcrédito.

O empréstimo em grupo, também denominado empréstimo de responsabilidade solidária, baseia-se no "colateral social” ou aval aval solidário. Basicamente, o aval solidário consiste no empréstimo em grupo de três ou mais membros no qual um avaliza o outro, criando assim uma corresponsabilidade dentro do grupo, pois o não pagamento do empréstimo por qualquer um dos membros compromete o grupo como um todo. Esse mecanismo não apenas substitui as garantias reais como também o monitoramento do empréstimo, já que os próprios tomadores se encarregam disso no lugar da instituição. 
Conning (1996) analisou o colateral social como uma ferramenta capaz de reduzir a possibilidade de risco moral dos empréstimos. Para o autor, o aval solidário fornece incentivos aos grupos de mutuários para que estes se auto monitorem.

Outra contribuição importante para o debate acerca dos empréstimos em grupo foi dada por Stiglitz (1993). Ele argumenta que empréstimos em grupo com responsabilidade solidária pode permitir que os mutuários obtenham empréstimos maiores do que obteriam por meio de empréstimos individuais.

Entretanto, Kaboski \& Townsend (2005) ao avaliarem o impacto de características institucionais em aldeias rurais na Tailândia concluíram que os os empréstimos em grupo, especialmente os grupos de mulheres são bem sucedidos quanto à intermediação do crédito junto aos seus membros embora, surpreendentemente não tenham identificado impacto da responsabilidade solidária.

No caso específico deste estudo, considera-se que as falhas do mercado de crédito (risco moral, assimetria informacional) podem também ser corrigidas através da regulação. A regulação, aqui, é abordada enquanto ação ou intervenção do Estado na condução das políticas públicas. Políticas públicas, por sua vez, são compreendidas como ações, normas e diretrizes implementadas pelo Estado, diretamente ou por meio de instituições com competência para tal, voltadas para segmentos específicos da sociedade e com a participação desta durante todo o processo (elaboração, implementação e avaliação).

No que concerne à política e regulação de microfinanças, existe uma lacuna nos estudos tanto internacionais como nacionais. No Brasil, os estudos estão concentrados na área do Direito a exemplo do estudo de Deangelo (2005), que analisou as ambiguidades da regulação brasileira de microfinanças e afirmou que, por meio do Programa Nacional de Microcrédito Produtivo Orientado (PNMPO), o microcrédito foi instrumentalizado como uma política social no âmbito do sistema financeiro.

Considerado um marco regulatório no Brasil, o PNMPO foi criado em 2005, assumindo o papel de regulador entre as instituições de microcrédito produtivo orientado e as instituições financeiras tradicionais (Barone \& Sader, 2008).

As ações, políticas e programas de microfinanças e de microcrédito são consideradas políticas regulatórias (públicas) sociais por visar corrigir as externalidades do mercado de crédito já discutidas. Miguel (2012) aborda o microcrédito como um programa governamental que representa um projeto de caráter social implantado via mercado financeiro e afirma que na esfera institucional, o PNMPO foi concebido como um modelo inovador de política 
pública por ter, em sua estrutura, uma rede composta por organizações autônomas que ingressam no programa por opção.

As principais mudanças sofridas pelo PNMPO na reformulação realizada em 2011 estão relacionadas à redução das taxas de juros e de abertura de crédito, além da criação de subsídios para financiar os bancos que decidissem aderir ao Programa. Outra mudança importante foi a criação de metas para os bancos públicos (Banco do Brasil, Banco do Nordeste, Banco da Amazônia e Caixa Econômica Federal) no intuito de fomentar o microcrédito produtivo orientado. Essas mudanças impactaram diretamente os bancos públicos e indiretamente as demais instituições, incluindo as cooperativas de crédito, objeto de análise deste estudo.

O microcrédito e as microfinanças possuem múltiplas dimensões e abordagens: (a) é uma estratégia de combate à pobreza e à exclusão social por meio da geração de ocupação e renda; (b) representa oportunidades de diversificação de produtos e serviços que garantam ganhos financeiros para as instituições financeiras tradicionais, dentre outras. Neste estudo, discute-se o tema numa perspectiva institucional e político-regulatória, uma vez que se preocupa em analisar o impacto das mudanças regulatórias de uma política pública específica (um programa brasileiro de microcrédito) no desempenho de instituições indiretamente afetadas por essas mudanças, as cooperativas de crédito.

Internacionalmente, os estudos de impacto da regulação no desempenho das instituições de microfinanças predominantemente tratam da discussão do fato de as IMFs serem ou não reguladas (Hartarska, Nadolnyak, \& Shen, 2012). No Brasil, também são raros os estudos que discutem o impacto das políticas de microcrédito no desempenho das instituições concedentes.

Tanto nacional quanto internacionalmente, os estudos nesse campo de conhecimento ou discutem o trade-off entre desempenho financeiro e desempenho social (Araújo, 2012; Bédécarrats et al., 2011; Borba, 2012; Foose \& Greenberg, 2008; Frank, 2008; Gonzalez, 2010; Gonzalez, 2010a; Kai, 2009; Kumar Kar, 2011; Sinha, 2006; Sinha \& Brar, 2005; Tulchin, 2004) ou tratam da regulação numa perspectiva normativa sendo, basicamente, guias de boas práticas (Berenbach \& Churchill, 1997; Christen \& Rosenberg, 2000; Deangelo, 2005; Jansson \& Wenner, 1997; Lauer \& Staschen, 2013; Ledgerwood, 1999; Macchiavello, 2012; Martins, Winograd, \& Salles, 2002; Meagher, 2002; Staschen, 1999; Van Greuning, Gallardo, \& Randhawa, 1998). Há outros que analisam o impacto de programas públicos de microcrédito no tomador final, isto é, na perspectiva da demanda por microcrédito (Braga, 2011; Neri \& Medrado, 2010). 
Assim, este estudo justifica-se por investigar os efeitos de mudanças regulatórias no âmbito das instituições concedentes, ou seja, apresenta um olhar sobre a oferta de microcrédito no Brasil.

No que tange aos estudos sobre o PNMPO, o estudo de Zancanella, Oliveira, Cunha, e Lima (2010) avalia o processo de implementação do programa em Minas Gerais, na percepção dos dirigentes das instituições habilitadas. O presente estudo traz uma perspectiva diferente na medida em que analisa o impacto das mudanças regulatórias ocorridas no programa no desempenho de um dos tipos de instituição que opera o Microcrédito Produtivo Orientado (MPO) no Brasil, a saber, as cooperativas de crédito.

Em junho de 2015, o Ministério do Trabalho e Emprego (MTE) publicou uma avaliação do PNMPO realizada por pesquisadores da Universidade de Brasília (UnB) (Belloni et al., 2015). Esse estudo trouxe algumas informações importantes acerca do programa e também das instituições concedentes, incluindo as cooperativas de crédito, objeto de análise desta pesquisa. A pesquisa foi feita nas instituições habilitadas com a participação de atores do governo, de bancos oficiais, entidades de microcrédito, agentes de microcrédito e também dos tomadores de empréstimos, por meio de pesquisa qualitativa e quantitativa. $\mathrm{O}$ mapeamento das instituições de microcrédito habilitadas no MTE foi realizado com 368 instituições que estavam cadastradas nesse órgão em fevereiro de 2014.

As principais mudanças regulatórias ocorridas em 2011, apontadas pelo referido estudo são:

(a) A Resolução do BCB no 4.000/2011 (Banco Central do Brasil [BCB], 2011), a qual estabeleceu que os bancos múltiplos com carteira comercial, os bancos comerciais e a Caixa Econômica Federal deveriam manter aplicados, em operações de crédito destinadas à população de baixa renda e a microempreendedores, valor correspondente a, no mínimo, 2\% dos saldos dos depósitos à vista captados pela instituição sendo que a partir de julho de 2013, no mínimo $80 \%$ (oitenta por cento) do saldo destas aplicações deveriam ser destinados para operações de microcrédito produtivo orientado;

(b) A criação do programa CRESCER, no âmbito do PNMPO, por meio da Medida Provisória $\mathrm{n}^{\mathrm{o}}$ 543, de 2011 (Brasil, 2011).

São, exatamente, os efeitos dessas mudanças que esta tese se propôs analisar.

No que se refere ao cooperativismo de crédito, a despeito da sua relevância para o sistema financeiro e mercado de crédito no Brasil, existem poucos estudos a respeito deste setor especialmente relacionados à oferta de microcrédito. O segmento de cooperativas de 
crédito é tão importante e ao mesmo tempo possui tantas especificidades, que o Banco Central do Brasil (BCB) criou um departamento específico para supervisioná-las, o Departamento de Supervisão das Cooperativas e de Instituições não Bancárias (Desuc). A escassez de estudos sobre cooperativismo decorre, sobretudo, da insuficiência de dados, sendo a principal fonte de informações a esse respeito o Banco Central do Brasil.

Portanto, um estudo dessa natureza justifica-se pelas razões apontadas.

\subsection{Objetivos}

Sendo assim, o presente estudo tem como objetivo geral analisar os efeitos de mudanças regulatórias no microcrédito no desempenho financeiro e social das cooperativas de crédito no Brasil. Como objetivos específicos, o estudo se propõe a:

○ Compreender o contexto geral do microcrédito no Brasil;

○ Entender, na percepção das instituições envolvidas, como se dá na prática a oferta de microcrédito;

- Examinar os efeitos de mudanças regulatórias no microcrédito em um tipo específico de instituição concedente: as cooperativas de crédito.

\subsection{Breve desenho metodológico}

A fim de alcançar o objetivo aqui proposto, a estratégia metodológica adotada foi o denominado experimento "natural" ou "quasi" experimento com dados não observacionais (não controlado pelo pesquisador) e com o suporte da técnica estatística diferenças em diferenças (conhecido na literatura internacional como diff-in-diff). Um experimento é um estudo em que são observados os efeitos de uma intervenção que é deliberadamente introduzida (Shadish, Cook \& Campbell, 2002). Já o experimento "natural”, para os autores, é um "quasi" experimento, uma vez que o tratamento não pode ser manipulado.

Nas ciências sociais aplicadas, essa metodologia vem sendo amplamente utilizada principalmente em estudos de avaliação de programas e políticas. $\mathrm{Na}$ Contabilidade, diversos estudos sobre tomada de decisões e análise de efeitos do IFRS (International Financial Reporting Standards) também têm utilizado o quasi experimento cada vez mais.

No segmento de microfinanças e microcrédito, diversos estudos têm utilizado a combinação de experimento natural com estimativas por diferenças em diferenças (Cozarenco \& Szafarz, 2014; Ledgerwood, 1999). 
As estimativas por diferenças em diferenças são realizadas, no presente estudo, por meio de indicadores contábeis de todas as cooperativas de crédito existentes no Brasil, as quais totalizavam, em dezembro de 2014, 1.098 (Banco Central do Brasil [BCB], 2015a). O período estudado foi de 2008 a 2014. O ano do evento (mudanças regulatórias ocorridas no microcrédito) é 2011. Assim, compararam-se as cooperativas que concedem ou concederam microcrédito em algum momento durante o período estudado (grupo de tratamento) com as que nunca o fizeram (grupo de controle). Comparou-se também o comportamento dos indicadores contábeis (financeiros e sociais) antes e após o evento.

A base de dados disponibilizada pelo BCB possibilitou a realização de estimações dos efeitos das mudanças regulatórias por diferenças em diferenças. A referida base é composta por dados extraídos do Sistema de Informações de Crédito (SCR) e do Plano Contábil das Instituições Financeiras (COSIF). O estudo utiliza ainda dados da coordenação do PNMPO, junto ao MTE, além de entrevistas realizadas com agentes qualificados nas instituições concedentes de microcrédito para a contextualização e refinamento das análises realizadas.

\subsection{Relevância e contribuições do estudo}

A principal pretensão deste estudo é capturar (ou chegar o mais próximo possível disso) o efeito das mudanças regulatórias do microcrédito no desempenho financeiro e social de cooperativas de crédito.

Por meio da literatura consultada, observou-se que estudos que abordam a oferta de microcrédito especificamente em cooperativas de crédito ainda são escassos no mundo, sendo no Brasil ainda mais raros. Lima (2004), por exemplo, analisou os efeitos da regulação do setor de microfinanças brasileiro, porém no caso específico das Sociedades de Crédito ao Microempreendedor (SCMs).

Os estudos no Brasil e internacionais que investigam os efeitos da regulação no desempenho de Instituições de Microfinanças (IMFs) têm crescido sobremaneira (Cull, Demirgüç-Kunt, \& Morduch, 2008; Morduch, 1999). No entanto, a maioria dos trabalhos consultados (Christen \& Rosenberg, 2000; Jansson \& Wenner, 1997; Lauer \& Staschen, 2013; Loubière, Devaney, \& Rhyne, 2004; Macchiavello, 2012; Martins et al., 2002; Meagher, 2002; Rosales, 2000; Staschen, 1999; Van Greuning et al., 1998) abordam a regulação de forma geral, discutindo se a IMF deve ou não ser regulada ou, ainda, apresentam a questão das "boas práticas" de regulação, numa perspectiva normativa. Founanou e Ratsimalahelo (2012) estudaram a regulação ideal de uma sociedade de crédito cooperativa 
que tem informações privadas sobre a qualidade intrínseca da sua carteira de crédito, porém, no âmbito de uma única instituição.

Sendo assim, este trabalho diferencia-se dos já realizados, na medida em que analisa os efeitos de mudanças regulatórias no desempenho financeiro e social de um tipo de instituição de microcrédito ainda pouco estudado (cooperativas de crédito) ao tempo em que também avalia programas específicos de microcrédito, PNMPO e CRESCER, cujos estudos a respeito ainda são incipientes.

Dentre os estudos sobre o PNMPO, um dos mais importantes identificado é o de Zancanella et. al. (2010), que avaliou a implementação do programa na percepção dos dirigentes das instituições habilitadas, por meio de entrevistas, e o recém-publicado relatório de avaliação do PNMPO (Belloni et al., 2015). Entretanto, estes estudos possuem abordagem predominantemente qualitativa e não apresentam o nível de detalhamento do presente estudo.

O levantamento e a análise exploratória de dados do Ministério do Trabalho e Emprego (MTE), principal gestor do PNMPO, trouxeram elementos para a escolha do tipo de IMF mais adequado à natureza do estudo aqui proposto. A pouca representatividade do microcrédito diante do total de operações dos grandes bancos revelou não ser relevante a análise do objeto na perspectiva dessas instituições. Quanto às Organizações da Sociedade Civil de Interesse Público (OSCIPs), não foi possível obter informações específicas, tendo em vista que não são reguladas pelo BCB e não há um órgão ou entidade que detenha uma base de dados consolidada desse segmento que permitisse um estudo acurado das suas operações. Em relação às $\mathrm{SCMs}$, a quantidade de instituições é muito pequena e, a partir dos Relatórios do PNMPO, observou-se uma redução significativa da participação destas instituições na oferta de microcrédito no Brasil. As agências de fomento, salvo raras exceções, operam como agentes intermediários e não atendem diretamente ao tomador final, portanto, estão fora do escopo do estudo, que se concentra em aspectos das concessões diretamente ao cliente final.

Dadas estas restrições aos tipos de IMCs mencionados, optou-se por um estudo mais aprofundado nas cooperativas de crédito. De acordo com Labie \& Périlleux (2008) a despeito do enorme desenvolvimento experimentado pelo segmento de microfinanças nos últimos anos, um tipo de instituição não gerou tanta atenção, a saber, as cooperativas de crédito. Para os autores, isso pode ter ocorrido em função de problemas inerentes à governança deste tipo de instituição. Assim, este estudo também tem a pretensão de contribuir para o preenchimento dessa lacuna.

Adicionalmente, uma análise como esta acerca das cooperativas de crédito justifica-se na medida em que, a despeito da representatividade deste segmento em termos de quantidade 
de instituições ${ }^{4}$, em relação à oferta de microcrédito, se mostra menos relevante frente a outros tipos de IMFs. Esta é outra importante questão abordada no presente estudo.

Além disso, o estudo se apresenta inovador, tanto por não ter se identificado na literatura estudos anteriores que abordem o PNMPO na perspectiva da regulação e da mensuração dos indicadores do double bottom line ${ }^{5}$, como também pelo ineditismo de uso da base de dados do regulador (o Banco Central do Brasil) ao nível analítico das operações (microdados) das cooperativas de crédito no país. Portanto, trata-se de uma base de dados inédita no mundo, de caráter restrito e de difícil acesso. Cabe ressaltar que, embora na área de microfinanças e microcrédito a utilização destes dados do COSIF por instituição possa ser considerado um ineditismo, estudos em outras áreas como análises de spread bancário, de indicadores de estabilidade financeira etc já fazem uso desses dados desde 2002 (Vide Afanasieff, Lhacer e Nakane, 2002; Dantas, Medeiros e Capelleto, 2012).

Os dados do MTE foram importantes para a contextualização da oferta de microcrédito no Brasil e melhor entendimento do programa estudado, qual seja, o PNMPO. As informações das entrevistas ajudaram na compreensão de como ocorre a oferta do microcrédito no contexto do programa nas instituições envolvidas, que é um elemento relevante para discussão dos resultados dos testes estatísticos realizados com os dados do BCB. Ademais, os dados e informações levantados no MTE e entrevistas realizadas, ainda que não se caracterizem como a principal fonte de dados do estudo, trouxeram informações inéditas sobre o PNMPO/CRESCER, pois trata-se de um programa relativamente novo e, desse modo, as pesquisas acerca deles encontra-se ainda em estágio inicial.

A inovação deste estudo também se deve ao uso da estratégia metodológica, a saber, um experimento natural com suporte da técnica de diferenças em diferenças. No Brasil, pesquisas sobre microfinanças e microcrédito que utilizam estratégia experimental ainda são pouco exploradas, especialmente nos estudos da área de Contabilidade. O mais relevante estudo identificado é o de Neri e Medrado (2010) da área de Economia, que investigou o impacto do programa Crediamigo, do Banco do Nordeste, no acesso ao crédito no Nordeste. No entanto, o escopo do trabalho é muito restrito: um programa e uma região.

\footnotetext{
${ }^{4}$ Conforme dados do World Concilia of Credit Unions (WOCCU), em dezembro de 2014, existiam 57.000 cooperativas de crédito espalhadas por 105 países dos 6 continentes, as quais atendiam a 217 milhões de pessoas (www.woccu.org).

${ }_{5}^{5}$ Double bottom line, grosso modo, diz respeito à busca do equilíbrio entre objetivos financeiros e sociais. Na literatura sobre mico finanças significa buscar igualmente a sustentabilidade financeira e o alcance social da IMF.
} 
Nesta perspectiva, o presente estudo avançou ao promover uma investigação em nível nacional a uma população de mais de mil instituições e ao utilizar uma série temporal semestral de sete anos, totalizando catorze períodos de tempo caracterizando, assim, um painel desbalanceado. Ademais, o objetivo do presente estudo diferencia-se ao olhar para os efeitos do programa sobre as instituições financeiras e não sobre os tomadores de recursos.

Embora se reconheça a pouca abrangência do presente estudo ao contemplar somente o universo das cooperativas de crédito, o estudo traz elementos novos que podem contribuir com as reflexões e discussões do mercado de microcrédito em geral pois, como visto, as cooperativas são o tipo de instituição que mais se assemelha ao que se convencionou considerar instituição de microfinanças, ou seja, organizações que buscam, ao mesmo tempo, objetivos econômicos e sociais.

Nesse sentido, considera-se que o presente estudo pode interessar a, no mínimo, três segmentos da sociedade: às instituições que concedem microcrédito, aos policy makers e à academia. Para as instituições, a pesquisa pode contribuir no âmbito do aprimoramento dos registros contábeis, assim como no uso de indicadores de avaliação de desempenho. Para os policy makers, traz informações novas e interessantes na perspectiva das instituições envolvidas que podem ser úteis quando da avaliação e aperfeiçoamento das políticas e programas de microcrédito no Brasil, principalmente do PNMPO e do CRESCER. Para a academia, o estudo apresenta uma questão de pesquisa não trivial nos estudos em Contabilidade e Finanças, um tema emergente e instigante, além de utilizar uma estratégia metodológica inovadora, a saber, um quasi experimento com auxílio da técnica diferenças em diferenças. Consequentemente, este estudo propicia a redução do hiato entre a academia e o setor produtivo da economia, otimizando a utilidade social da pesquisa.

Por fim, esta pesquisa, também, contribui para o debate (proposição e avaliação) e para a construção de políticas públicas voltadas para a regulação de instituições de microcrédito (perspectiva macroeconômica), ao propor melhorias nos programas PNMPO e CRESCER, assim como acrescenta novos elementos à definição e uso de indicadores de desempenho econômico-financeiro e de performance social em instituições de microcrédito, especificamente, em cooperativas de crédito (perspectiva microeconômica).

Em síntese, o estudo justifica-se por trazer as inovações e contribuições descritas e por fomentar uma nova agenda de pesquisa, uma vez que o assunto aqui discutido é vasto e ainda pouco explorado. 


\subsection{Estrutura do trabalho}

O trabalho está organizado da seguinte forma: além desta Introdução, apresenta mais quatro capítulos. No Capítulo II encontra-se a fundamentação teórico-conceitual da pesquisa, além da revisão de literatura. O Capítulo III descreve o desenho da pesquisa, define as variáveis de estudo e retrata os procedimentos metodológicos adotados. O Capítulo IV compreende a análise e discussão dos dados. O Capítulo $\mathrm{V}$ descreve os resultados evidenciando as conclusões do estudo, além de mostrar suas limitações. Este último capítulo apresenta ainda sugestões para pesquisas futuras. 


\section{QUADRO TEÓRICO-CONCEITUAL}

Neste capítulo, discute-se o corpo teórico deste estudo de forma mais aprofundada, o qual baseia-se em conceitos e definições acerca de microfinanças, microcrédito e cooperativismo de crédito, além das contribuições teóricas da Teoria da Regulação e Teoria (Neo)Institucional.

\subsection{Microfinanças e microcrédito}

Embora o microcrédito tenha surgido no século XIX com as cooperativas de crédito, as experiências contemporâneas de microfinanças surgiram em meados da década de 1970, a partir de movimentos paralelos na América Latina e na Ásia (Aghion \& Morduch, 2005).

Microfinanças consiste na oferta de serviços financeiros em geral: poupança, seguro, além do crédito em todas as suas modalidades (consumo, habitacional etc.) para a população de baixa e renda e para microempreendedores. O microcrédito é um dos produtos das microfinanças e se refere a todas as modalidades de crédito ofertado para esse mesmo público (pobres e pequenos empreendedores). Já o microcrédito produtivo e orientado, de acordo com Soares e Melo Sobrinho (2008), é aquele destinado exclusivamente a atividades produtivas, com exclusão do crédito de consumo. A Figura 1 resume as diferenças conceituais entre microfinanças, microcrédito e microcrédito produtivo e orientado, conforme os referidos autores.
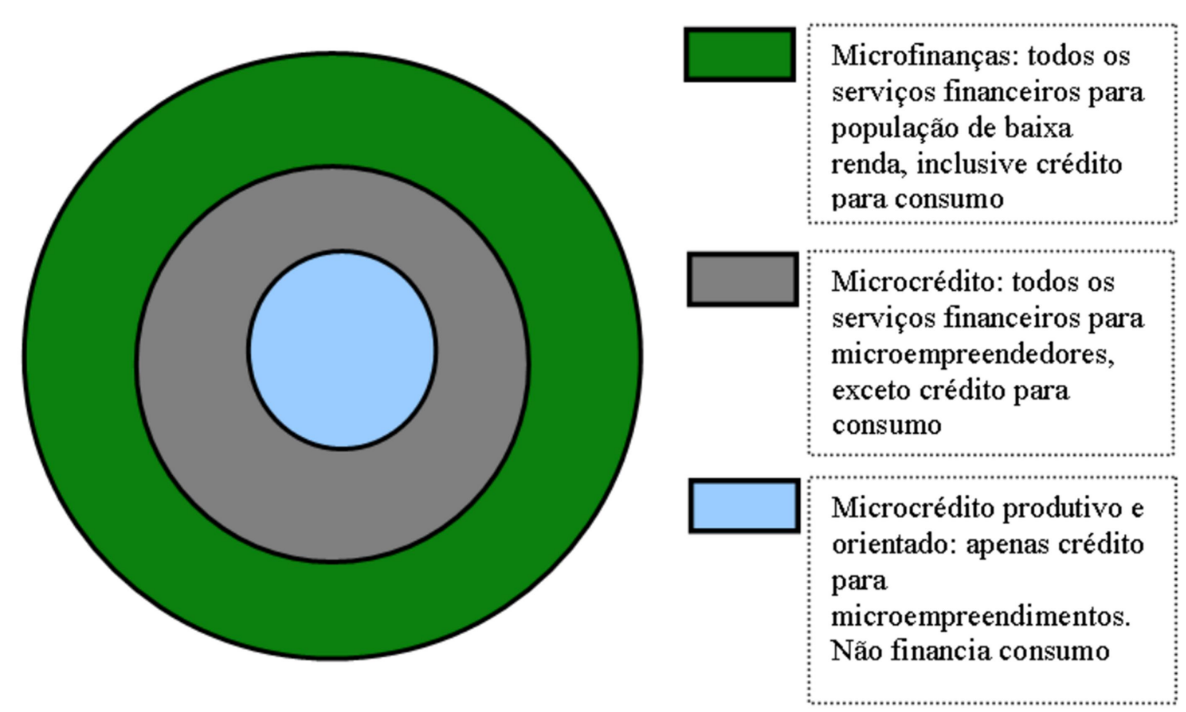

Figura 1: Diferenças conceituais entre microfinanças, microcrédito e microcrédito produtivo e orientado. Fonte: Soares e Melo Sobrinho (2008, p. 25). 
O microcrédito, especialmente o produtivo e orientado, segue uma metodologia própria, criada e disseminada com base na experiência do Grameen Bank. A principal metodologia do microcrédito é o aval solidário, que se baseia na confiança mútua e nos laços de proximidade entre os beneficiários dos recursos. $\mathrm{O}$ aval solidário ou colateral social consiste no empréstimo em grupo no qual os membros são corresponsáveis pela adimplência. Essa metodologia foi criada, sobretudo, para substituir as garantias reais, difíceis de serem obtidas nas camadas mais desassistidas socialmente.

Embora os empréstimos em grupo tenham tido uma rápida expansão a partir do início dos anos 1970, por meio do trabalho da ONU no Brasil e do Grameen Bank em Bangladesh, esse conceito remonta ao século XIX (Bastelaer (2000). O autor atribui a origem dessa tecnologia às cooperativas de crédito criadas por Raiffeisen na Alemanha em meados do século XIX, as quais ficaram conhecidas como "bancos do povo" especialmente por praticarem os empréstimos em grupo cujos critérios eram: residência em pequenas comunidades rurais, garantia pelos membros e corresponsabilidade dos colegas pelos empréstimos (Bastelaer (2000).

O empréstimo com base na responsabilidade solidária pode mitigar o problema do risco moral (Aghion \& Morduch, 2005), uma vez que leva os membros do grupo ao acompanhamento dos empréstimos de cada um, mecanismo denominado por Stiglitz (1993) de monitoramento dos pares. O modelo teórico de Stiglitz (1993) mostra como o monitoramento dos pares pode ajudar a mitigar o risco moral. Esse automonitoramento do grupo pode ainda reduzir os custos de monitoramento das instituições que emprestam, pois este custo é transferido para o grupo. Conning (1996) considera os custos de monitoramento dentro do grupo e admite a possibilidade de um trade-off uma vez que o colateral social reduz a inadimplência, mas, segundo o autor, gera um custo de monitoramento pelos pares.

Outra discussão a respeito dos empréstimos de responsabilidade solidária trata da relevância dos laços sociais entre os membros do grupo. Embora grande parte da literatura ateste que fortes laços sociais facilitam tanto o monitoramento pelos pares como a punição em caso de inadimplência, Ahlin \& Townsend (2007) constataram que esses laços sociais também podem gerar conflitos de interesses entre os membros e, às vezes, pode tornar mais difícil a pressão dos membros pelo pagamento dos empréstimos. Labie \& Périlleux (2008) realizaram um estudo sobre empréstimos em grupo em cooperativas de crédito e concluíram que esses mecanismos - colateral social e monitoramento dos pares - parecem desempenhar um papel chave uma vez que os membros da cooperativa reembolsam seus empréstimos, não 
somente devido à pressão social, mas também porque o dinheiro que está pagando é o seu próprio e dos membros do grupo. Os autores constaram que a maioria das experiências mal sucedidas com empréstimos em grupo nas cooperativas de crédito por eles analisadas são devido a deficiências na implementação desta metodologia.

Outros estudos consideram esses laços sociais, também denominado capital social ${ }^{6}$, relevantes para o sucesso dos empréstimos em grupo. Cassar, Crowley \& Wydick (2007), por exemplo, através de um experimento realizado na África, discutiram a contribuição do capital social para o desempenho dos empréstimos em grupo, os quais por sua vez, na opinião dos autores, contribuem para a redução da inadimplência. $\mathrm{O}$ estudo apresenta evidências de que os laços de confiança pessoal entre os membros do grupo e a reciprocidade são determinantes para o reembolso do empréstimo.

Outra característica das microfinanças diz respeito aos empréstimos progressivos ou incentivos dinâmicos que consiste na concessão de empréstimos crescentes condicional ao repagamento dos anteriores (Neri \& Medrado, 2010). Em caso de inadimplência, os empréstimos não são renovados. Essa possibilidade de não renovação funciona como um incentivo à adimplência.

\subsection{Microfinanças e cooperativismo de crédito}

O cooperativismo, enquanto movimento ou doutrina tem sua fundamentação teórica no pensamento dos denominados socialistas utópicos: Robert Owen, Willian King, Buchez, dentre outros e, numa perspectiva teórica, utiliza o instrumental econômico-administrativo (Pinho, 2004). Assim, as teorias que fundamentam as cooperativas são as mesmas que se aplicam a qualquer organização, obviamente respeitando as especificidades inerentes às sociedades cooperativas. Dentre as teorias organizacionais, as mais aplicadas às cooperativas são a Teoria Econômica da Cooperação, desenvolvida na Universidade de Münster, na Alemanha (Pinho, 1982) e a Teoria da Agência. A primeira tornou possível a realização de estudos mais detalhados dos instrumentos de controle das cooperativas com foco na produtividade e na efetividade fazendo uso de modernas técnicas organizacionais (Pinho, 2001). A Teoria da Agência considera a organização como um conjunto de contratos, na qual

\footnotetext{
${ }^{6}$ O conceito de capital social foi disseminado por Putnam (1997) que, baseando-se no modelo utilitarista de Coleman (1988), desenvolveu instrumentos empíricos a fim de investigar de que forma o capital social pode ajudar a resolver os problemas da ação coletiva, no sentido de se obter cooperação social e de como essa cooperação social pode se refletir no desempenho das instituições. Assim, para Putnam (1997), capital social é um conjunto de características da organização social (confiança, normas e sistemas) que tornam possíveis ações coordenadas.
} 
uma das partes (principal) autoriza que a outra (agente) tome decisões em seu nome e, assim, gera conflito de interesses decorrentes da separação entre a propriedade e o controle do capital. Esse conflito gera assimetria de informação entre o agente e o principal. A teoria pressupõe ainda que o agente é contratado pelo principal a fim de garantir a maximização dos lucros dos acionistas no longo prazo, mas o agente também busca maximizar suas utilidades pessoais e, muitas vezes, tomam decisões em sentido contrário aos objetivos dos acionistas (Jensen \& Meckling, 1976). A busca pela maximização do lucro e da utilidade de ambos (agente e principal) baseia-se no pressuposto da racionalidade limitada das teorias do consumidor e da firma.

Tratando-se especificamente de cooperativas de crédito, estas diferenciam-se das demais instituições financeiras quanto à tomada de decisões, conforme Railienė \& Sinevičienè (2015). Sendo assim, enquanto a instituição financeira típica busca aumentar o valor para os acionistas, de acordo com a Teoria da Agência, as cooperativas de crédito, por possuírem simultaneamente objetivos econômicos e sociais viabilizam o retorno para os membros por meio da oferta de serviços financeiros em condições mais favoráveis. Desse modo, ainda de acordo com Railienè \& Sinevičienè (2015), não há conflitos de interesses entre os depositantes e tomadores de empréstimos tendo em vista que o acionista e o cliente são a mesma pessoa.

\subsection{Breve histórico do cooperativismo}

O primeiro registro de uma cooperativa data do século XIX, mais especificamente em 1844, na cidade inglesa de Rochdale, quando 28 tecelões fundaram uma cooperativa de consumo (Pinheiro, 2008). Antes disso, porém, já existiam experiências financeiras voltadas aos pobres, as quais segundo Búrigo (2006), tiveram início na Europa durante o século XVIII e culminaram mais tarde no cooperativismo de crédito. Segundo este último autor, o cooperativismo de crédito foi criado por Raiffeisen em 1848, na Alemanha, que além de experimentar várias formas de cooperativas (de consumo e de crédito), teria estudado outras experiências de cooperativas bem-sucedidas, além de publicar um livro, em 1866, onde foram inseridos alguns princípios do cooperativismo, os quais estariam presentes nas cooperativas de crédito modernas.

As primeiras experiências cooperativistas foram influenciadas, segundo Bialoskorski Neto (1998), por duas correntes teóricas conhecidas como socialistas utópicos e socialistas científicos, os quais defendiam uma estrutura econômica e social que sobrepusessem o 
homem ao capital. Desde então, o cooperativismo de crédito cresceu, principalmente na Europa, onde esse movimento é mais forte até hoje.

A partir de então, surgem outros tipos de cooperativas. Luigi Luzzatti criou a primeira cooperativa de crédito na Itália, sem nenhum tipo de vínculo associativo, ou seja, não necessariamente os cooperados precisavam pertencer a um mesmo ofício ou morar em uma mesma região (conhecido como tipo luzzatti). No Canadá, Alfonse Desjardins implementou um outro tipo de cooperativa que exigia algum tipo de vínculo entre os sócios (Pinheiro, 2008). Esse tipo é conhecido no Brasil como cooperativa de crédito mútuo.

A primeira Cooperativa criada no Brasil surge em Ouro Preto, Minas Gerais, em 1889 (Pinheiro, 2008). Já as primeiras cooperativas de crédito surgiram em 1902, no Rio Grande do Sul. No entanto, as cooperativas de crédito vieram a se consolidar a partir da década de 1990 com o surgimento dos sistemas de crédito cooperativo, especialmente o Sicredi e o Sicoob, que hoje possuem cada um seus próprios bancos cooperativos.

Nos anos 2000, mais especificamente em 2003, a Resolução do BCB nº 3.106 (Banco Central do Brasil [BCB], 2003) criou regras novas para a constituição e funcionamento das cooperativas e permitiu o retorno das cooperativas de livre admissão.

Desde então, as modalidades (tipos) de cooperativas de crédito em funcionamento no Brasil são: (a) cooperativas de crédito mútuo; (b) cooperativas de crédito rural; (c) cooperativas de crédito mútuo de atividade profissional (áreas afins, complementares ou correlatas); (d) cooperativas de crédito mútuo de empreendedores (pequenos empresários, microempresários ou microempreendedores que possuam negócios de natureza industrial, comercial ou de prestação de serviço de pequeno porte); (e) cooperativas de crédito de empresários (empresas vinculadas a sindicatos e associações patronais); (f) cooperativas de livre admissão; (g) cooperativas luzzatti (o BCB reconhece somente as que já existiam anteriormente, proibindo a constituição de novas cooperativas com essa denominação; (h) cooperativas "mistas". Com base na legislação - principalmente a Resolução do BCB n⿳0 3.106/03 (BCB, 2003), as cooperativas de crédito brasileiras estão autorizadas a: (a) captar depósitos de associados; (b) obter empréstimos ou repasses de organizações financeiras nacionais ou internacionais; (c) receber recursos oficiais e, em caráter eventual, receber doações (Búrigo, 2006).

\subsection{Cooperativas de crédito: definição e classificação}


As cooperativas de crédito são relevantes atores na indústria de microfinanças no mundo e se organizam em diferentes modelos a exemplo do sistema Desjardins no Canadá, Rabobank na Holanda, Credit Agricole na França, Mondragon na Espanha, National Credit Union Administration (NCUA) nos Estados Unidos e Deutsche Genossenschafts- und Raiffeisenverband e.V. (DGRV) na Alemanha (Huppi \& Feder, 1990).

A relevância desse segmento é ressaltada por Gaboury e Quirion (2006) ao afirmarem que as cooperativas de crédito são organizadas em estreita proximidade com as comunidades que servem e, normalmente, estão localizadas em áreas rurais ou em comunidades que são ignorados por outros tipos de instituições financeiras. Ward \& McKillop (2005) consideram que as características específicas das cooperativas de crédito contribui para reduzir a assimetria de informação permitindo-lhes fornecer empréstimos de maneira e em locais em que outras instituições financeiras não podem tornando-as, assim, um potencial instrumento na luta contra a exclusão financeira.

Nesse sentido, considerando o seu duplo objetivo de proporcionar menores taxas de empréstimos e maiores taxas de remuneração dos depósitos para os membros (Gaboury \& Quirion, 2006), as cooperativas de crédito são definidas como instituições financeiras formadas por pessoas que se unem voluntariamente de forma associativa, com forma e natureza jurídica próprias, de natureza civil, sem fins lucrativos, constituída para prestar serviços a seus associados (Banco Central do Brasil [BCB], 2005). As cooperativas de crédito são classificadas como singulares, ou cooperativas de $1^{\underline{0}}$ grau - aquelas destinadas a prestar serviços diretamente aos associados -; centrais e federações ou cooperativas de $2^{\underline{0}}$ grau constituídas por cooperativas singulares - e; confederações ou cooperativas de $3^{\underline{0}}$ grau constituídas por centrais e federações de cooperativas (Pinheiro, 2008).

As cooperativas de crédito se assemelham a Organizações Não Governamentais (ONGs) e Organizações da Sociedade Civil de Interesse Público (OSCIPs) por não visarem ao lucro e ao mesmo tempo possuem similaridades com os bancos convencionais por serem, além dos bancos, o único tipo de Instituição Financeira (IF) legalmente autorizado pelo BCB a captar depósitos (poupança) perante o público. Sendo assim, apresentam um formato institucional adequado para a oferta de serviços financeiros a populações pobres, pois não possuem fins lucrativos ao mesmo tempo em que desempenham a função de intermediário financeiro. Outro aspecto que diferencia as cooperativas de crédito de outros tipos de instituições financeiras é o fato de constituírem uma estrutura local que combina atividades de cunho financeiro e social, além de apresentarem características organizacionais baseadas na 
mutualidade e na autogestão, que facilitam a seleção e o monitoramento do crédito, além de reduzir os custos operacionais (Schroder, 2005).

O Sistema de Crédito Cooperativo (SCC) no Brasil vem aumentando substancialmente sua participação no sistema financeiro nacional. De acordo com o Banco Central do Brasil (BCB, 2012a), o SCC tem se destacado em duas importantes modalidades de crédito: empréstimos sem consignação e microcrédito. Em estados como Mato Grosso e Rio Grande do Sul, a oferta de microcrédito pelo SCC é superior a $90 \%$, corroborando a relevância econômica e social desse segmento.

Como o objetivo precípuo do microcrédito e das microfinanças é alcançar os mais pobres, as cooperativas têm um papel importante quanto a isso na medida em que espalhamse por todo o território nacional chegando, inclusive, a municípios mais distantes e menos favorecidos economicamente.

\subsection{Cooperativismo de crédito solidário}

Denominado por Pinho (2004) como a vertente solidária, e pelo BCB de segmento horizontalizado (Alves \& Soares, 2004), surge dentro do movimento cooperativista com base em movimentos sociais e numa lógica de atuação em rede, voltando seu atendimento aos segmentos de baixa renda, o que se convencionou chamar de cooperativismo solidário.

O cooperativismo solidário combina temporalmente com a difusão das microfinanças, no cenário internacional e nacional (Búrigo, 2006). O autor ressalta que estas experiências surgiram no Brasil na primeira metade da década de 1990, simultaneamente no oeste catarinense e sudoeste paranaense (o Sistema de Cooperativas de Crédito Rural Solidário CRESOL) e no semiárido baiano (a Associação das Cooperativas de Apoio à Economia Familiar - ASCOOB), tendo estas cooperativas atuado preponderantemente no meio rural. O Sistema CRESOL hoje é o mais desenvolvido e está dividido em central (órgão que presta serviços e representa políticas das cooperativas filiadas), bases regionais (prestadoras de serviços técnicos e contábeis às cooperativas do grupo) e cooperativas singulares (Bittencourt, 2001). O cooperativismo de crédito com interação solidária, de acordo com este autor, apresenta peculiaridades, pois comtempla fatores como: (a) gestão política democrática, participativa e solidária; (b) gestão profissional com filosofia de viabilidade econômica, financeira e de qualidade dos serviços ao tempo em que também considera as peculiaridades da organização cooperativa. 
Nesta perspectiva, as cooperativas de crédito solidárias juntamente com bancos do povo, fundos rotativos dentre outras organizações e programas dessa natureza, formam o movimento denominado finanças solidárias. Esse movimento questiona o papel das grandes cooperativas quanto à capacidade de atender às camadas sociais menos favorecidas e tenta resgatar os princípios elaborados pelos precursores do cooperativismo nos séculos XVIII e XIX.

Mesmo as cooperativas de crédito solidárias tendo originado de movimentos sociais, ainda encontram dificuldades para avançar em segmentos mais empobrecidos - os "mais pobres dos pobres" ou os extremamente pobres ${ }^{7}$-, público-alvo das ações de microcrédito (Búrigo, 2006). Alcançar “os mais pobres dos pobres" tem sido o desafio de todos os tipos de instituições de microfinanças no mundo inteiro.

No Brasil, as cooperativas que mais têm atuado no microcrédito são as do segmento solidário ou horizontalizado.

\subsection{A Nova Economia Institucional e as Instituições de Microfinanças}

A Nova Economia Institucional (NEI) baseia-se em um dos pressupostos da economia neoclássica, qual seja, a escolha racional. Essa escola do pensamento econômico destaca o papel das instituições no sistema econômico assegurando que o desempenho das economias depende da eficiência das instituições que as compõem (North, 1990).

Alguns estudos acerca do funcionamento dos mercados de crédito têm se utilizado dessa abordagem para a explicação das imperfeições de mercado, como a assimetria informacional, que levam ao aumento dos custos de transação. Para efeito deste trabalho, essa abordagem é utilizada para uma melhor compreensão das instituições e seu papel no mercado de microcrédito brasileiro. Assim, o conceito de instituição adotado nesta pesquisa está fundamentado nos trabalhos de North (1990) e Williamson (1985). A escolha deste enfoque teórico foi motivada pela crescente literatura internacional que estuda as instituições sob a ótica da abordagem (Neo)Institucionalista e, em particular, as IMFs cujo desempenho não obedece apenas a critérios de eficiência econômico-financeiros.

A agenda da inclusão financeira deriva da abordagem teórica da Nova Economia Institucional - NEI - (Johnson, 2013). Essa abordagem defende a intervenção nos mercados, e essa intervenção baseia-se na análise de como esses mercados podem funcionar de forma

\footnotetext{
${ }^{7} \mathrm{O}$ conceito de pobreza e extrema pobreza varia muito entre os autores. O Banco Mundial considera pobre o indivíduo que vive com 1 a 2 dólares norte-americanos por dia, e extremamente pobre o que vive com menos de 1 dólar/dia.
} 
mais eficaz, ajustando as regras e regulamentos e facilitando o fornecimento de informações e serviços que podem reduzir os custos de transação para os participantes do mercado. $\mathrm{O}$ reconhecimento de que as instituições formais e informais afetam os mercados, e a ênfase na regulamentação, são aspectos destacados por este enfoque. Outro tópico importante refere-se à sustentabilidade das instituições no longo prazo.

Sendo assim, uma das principais contribuições do (Neo)Institucionalismo refere-se ao papel das instituições no desenvolvimento econômico e à explicação do processo pelo qual as instituições surgem ou se modificam. Para efeito deste trabalho, esse referencial permite uma melhor compreensão do ambiente institucional no qual as IMFs estão inseridas, ambiente este que, conforme Williamson (1985), é formado por um conjunto de instituições, as quais são constituídas por leis, normas, costumes e direitos de propriedade que, por sua vez, constituem os parâmetros para a interação humana.

O ambiente institucional é modificado pelas instituições, que também sofrem influências do ambiente, ou seja, existe uma relação simbiótica entre instituições e ambiente. As instituições, por um lado, são moldadas pelo ambiente institucional; e por outro, elas definem as transformações do ambiente. É a partir de pequenas mudanças (incrementais) que a estrutura institucional vai alterando e modificando aos poucos o conjunto de regras formais e informais (instituições).

No que se refere ao ambiente institucional das microfinanças, possui lógica própria, instituições diferenciadas, formas diversificadas e flexíveis de garantias e controles de crédito - a exemplo do aval solidário -, além de tecnologias de produtos financeiros mais adequados à realidade dos clientes de baixa renda.

Instituições microfinanceiras são definidas por Morduch (1999) como Instituições Financeiras (IFs) especializadas, unidas sob a bandeira de microfinanças, que compartilham o compromisso de trabalhar para a inclusão financeira. Ledgerwood (1999) refere-se a estas como prestadores de serviços financeiros aos pobres, especialmente crédito e poupança.

As Instituições de Microfinanças (IMFs), orginalmente, surgem com um caráter eminentemente social e são consideradas instituições socialmente orientadas por excelência. Com o crescimento e a diversificação da indústria de microfinanças no mundo e, em particular na América Latina, há cada vez mais IMFs orientadas comercialmente. Contudo estas últimas, apesar de seu caráter eminentemente comercial, mantêm (ou tentam manter) o caráter social que lhes justifica a razão de existência.

A maioria das IMFs vê microfinanças como uma forma rentável de redução da pobreza, e de acordo com a forma com que cada uma oferece os serviços financeiros, podem 
ser classificadas como minimalistas: - ofertam produtos e serviços apenas financeiros; ou integradas - quando oferecem serviços não financeiros como um meio de melhorar a capacidade de seus clientes para estes utilizarem serviços financeiros: capacitação, educação financeira etc. (Ledgerwood, 1999). Complementa a autora que as IMFs de modo geral, principalmente as que operam o microcrédito, possuem como objetivos: (a) a redução da pobreza; (b) o fortalecimento de grupos minoritários, como o de mulheres pobres; (c) a criação de empregos; (d) a ajuda aos pequenos empreendedores para que fortaleçam o próprio negócio ou mesmo diversifiquem as próprias atividades; e (e) o estímulo ao desenvolvimento de novos pequenos negócios.

As IMFs, em geral, são organizadas de acordo com a sua orientação em relação ao resultado das operações, se buscam ou não a obtenção de lucros. Dentro dessa classificação lucrativas ou não lucrativas - ainda há uma diversificação de tipos de IMFs que vão desde ONGs com e sem fins lucrativos a bancos comerciais especializados em microfinanças. A Figura 2 mostra as principais características de cada tipo de IMF no Brasil. 


\begin{tabular}{|c|c|c|c|c|}
\hline Tipos de IMF & Forma societária & \begin{tabular}{|c|} 
Origem dos recursos \\
\end{tabular} & Ambiente regulatório & Orientação \\
\hline ONGs & Associação civil & $\begin{array}{l}\text { o Doações } \\
\text { O Investidores individuais e institucionais } \\
\text { ○ Repasses de programas públicos } \\
\text { o Fundos rotativos }\end{array}$ & Não reguladas & Não lucrativas \\
\hline Bancos privados & $\begin{array}{l}\text { Sociedade anônima de capital } \\
\text { aberto }\end{array}$ & $\begin{array}{l}\text { o Recursos próprios } \\
\text { o Repasses de programas públicos } \\
\text { o Investidores individuais e institucionais }\end{array}$ & Reguladas pelo Banco Central & Lucrativos \\
\hline Bancos públicos & Estatais e de Sociedade mista & $\begin{array}{l}\text { o Recursos próprios } \\
\text { o Recursos públicos (fundos constitucionais, orçamentos } \\
\text { estaduais e municipais, Fundo de Amparo ao Trabalhador - } \\
\text { FAT, FGTS etc.) }\end{array}$ & Regulados pelo Banco Central & Lucrativos \\
\hline Bancos comunitários & $\begin{array}{lr}\begin{array}{l}\text { Associação civil } \quad \text { (ONGs, } \\
\text { OSCIPs, } \\
\text { comunitárias etc.) }\end{array} & \text { Associações }\end{array}$ & $\begin{array}{l}\text { o Doações } \\
\text { o Fundos rotativos } \\
\text { o Investidores individuais e institucionais } \\
\text { o BNDES }\end{array}$ & Não regulados & $\begin{array}{l}\text { Não priorizam o } \\
\text { lucro, mas quando } \\
\text { ocorre é socializado }\end{array}$ \\
\hline Bancos de desenvolvimento & $\begin{array}{l}\text { Sociedade anônima, com } \\
\text { controle acionário do Estado } \\
\text { onde está sediado }\end{array}$ & $\begin{array}{l}\text { o Recursos próprios } \\
\text { o Recursos públicos (fundos constitucionais, Fundo de } \\
\text { Amparo ao Trabalhador - FAT, FGTS etc.) } \\
\text { o Agências multilaterais (Banco Mundial, Banco } \\
\text { Interamericano de Desenvolvimento - BID etc.) }\end{array}$ & Regulados pelo Banco Central & Lucrativos \\
\hline OSCIPs & $\begin{array}{l}\text { Associação civil de direito } \\
\text { público }\end{array}$ & $\begin{array}{l}\text { O Doações } \\
\text { ○ Repasses de programas públicos }\end{array}$ & $\begin{array}{l}\text { Reguladas pelo Ministério da } \\
\text { Justiça }\end{array}$ & Não lucrativas \\
\hline $\begin{array}{l}\text { Sociedades de Crédito ao } \\
\text { Microempreendedor } \\
\text { (SCMs) }\end{array}$ & $\begin{array}{l}\text { Sociedade anônima de capital } \\
\text { aberto ou fechado }\end{array}$ & $\begin{array}{l}\text { o Recursos próprios } \\
\text { o Investidores individuais e institucionais }\end{array}$ & Reguladas pelo Banco Central & Lucrativas \\
\hline Agências de Fomento & $\begin{array}{l}\text { Sociedades Anônimas de } \\
\text { capital fechado }\end{array}$ & $\begin{array}{l}\text { o Recursos próprios } \\
\text { o Recursos provenientes de fundos e programas oficiais } \\
\text { o Orçamentos federal, estaduais e municipais } \\
\text { o Organismos e instituições financeiras nacionais e } \\
\text { internacionais de desenvolvimento (BNDES, Banco } \\
\text { Mundial etc.) } \\
\text { o Captação de depósitos interfinanceiros vinculados a } \\
\text { operações de microfinanças (DIM) }\end{array}$ & $\begin{array}{l}\text { Supervisionadas pelo Banco } \\
\text { Central e controladas pelos } \\
\text { entes federativos onde têm sede }\end{array}$ & Lucrativas \\
\hline Cooperativas de crédito & $\begin{array}{l}\text { Associação civil (Sociedade } \\
\text { cooperativa) }\end{array}$ & $\begin{array}{l}\text { o Recursos próprios (depósitos de poupança dos proprietários/ } \\
\text { membros) } \\
\text { o Repasses de programas públicos } \\
\text { o Investidores individuais e institucionais }\end{array}$ & $\begin{array}{l}\text { Reguladas pelo Banco Central e } \\
\text { supervisionadas } \\
\text { cooperativas centrais }\end{array}$ & $\begin{array}{l}\text { Não priorizam o } \\
\text { lucro, mas quando } \\
\text { ocorre é distribuído } \\
\text { entre os sócios }\end{array}$ \\
\hline
\end{tabular}

Figura 2: Quadro Principais características organizacionais das Instituições de Microfinanças (IMFs) brasileiras.

Fonte: Elaboração própria com base em Martins, Winograd \& Salles (2002); Rock, Otero \& Saltzman (1998); BCB; MIX. 
Em nível mundial, durante muitos anos, o paradigma comercial priorizou a sustentabilidade financeira como a melhor forma de otimizar a eficiência. Na América Latina, cada vez mais há uma polarização em torno destas características: de um lado, há uma lógica meramente mercantil e, de outro, um grupo de instituições submetidas às políticas públicas Bédécarrats et al. (2013). Na opinião dos autores, o Brasil é uma exceção por adotar abordagem alternativa. O Brasil não adotou o denominado "modelo clássico" de microcrédito baseado no aval solidário, mas um modelo híbrido. Algumas experiências, a exemplo do Programa Crediamigo do Banco do Nordeste optaram por esta tecnologia, porém outras organizações operam o microcrédito comercialmente como é o caso dos bancos privados e SCMs.

De fato, no Brasil, os tipos de instituições concedentes de microcrédito vão desde as puramente comerciais, caso das SCMs, às eminentemente solidárias: ONGs, OSCIPs, Bancos do Povo. Em relação às cooperativas de crédito no Brasil, apesar de nenhum tipo priorizar o lucro, existem as de crédito solidário que se diferenciam das demais tanto no que se refere ao tipo de microcrédito ofertado, o produtivo e orientado, quanto ao público-alvo: microempreendedores (formais e informais).

Com efeito, as IMFs possuem originalmente um duplo objetivo ou uma "dupla missão" à qual se somam os objetivos social e econômico. Por um lado, a missão social consiste em ofertar produtos e serviços financeiros à maior parcela possível da população de baixa renda. De outro lado, a missão econômico-financeira relaciona-se à autossustentabilidade, que consiste na capacidade de a instituição manter-se sem o auxílio de doações ou subsídios. Esses dois objetivos, para alguns autores, são mutuamente excludentes; para outros, não o são.

Embora as primeiras IMFs tenham sido as ONGs e bancos especializados, a exemplo do Grameen Bank (Soares \& Melo Sobrinho, 2008), atualmente o ambiente institucional das microfinanças é bastante diversificado, sobretudo no Brasil, onde há dois tipos básicos de IMFs, quais sejam, as de "primeiro piso" - que atuam diretamente com o cliente final -, e as de "segundo piso" - que fornecem funding para as IMFs de "primeiro piso" por meio de empréstimos e repasses além de capacitação e apoio técnico ${ }^{8}$.

Tratando especificamente das cooperativas de crédito, estas são o tipo de instituição que mais se aproxima da concepção de IMF, por constituírem uma sociedade de pessoas e não

\footnotetext{
${ }^{8}$ No Brasil, algumas agências de fomento, a exemplo da Desenbahia, são instituições de $1^{\circ}$ e e $2^{\underline{o}}$ pisos, ou seja, atuam tanto como repassadoras e financiadoras de outras instituições a exemplo das OSCIPs e das cooperativas de crédito (ações de $1^{\circ}$ piso) como também concedem empréstimos diretamente para o cliente (ações de $2^{\underline{o}}$ piso).
} 
de capital - não têm o lucro como prioridade. De acordo com Carvalho, Diaz, Bialoskorski Neto e Kalatzis (2015), uma característica importante das cooperativas de crédito é que elas, ao mesmo tempo, buscam eficiência operacional e social. Ademais, conforme Banco Central do Brasil (BCB, 2013), no Brasil as principais instituições a ofertar microcrédito foram as cooperativas de crédito e as ONGs.

Segundo Ojong (2014), as cooperativas de crédito constituem um canal autossustentável capaz de alcançar os segmentos de baixa renda. $\mathrm{O}$ autor afirma ainda que a crise financeira de 2008 demonstrou o poder das cooperativas em geral. Fato que comprova isso foi as Nações Unidas declararem 2012 como o Ano Internacional das Cooperativas.

Nos últimos anos, o cooperativismo de crédito tem crescido não somente em números de cooperativas e de cooperados, mas também o interesse acadêmico e o número de estudos relacionados a esse segmento. Hartarska et al. (2012), por exemplo, estudaram a eficiência de cooperativas microfinanceiras. Analisaram 216 cooperativas de 41 países que reportaram para a base MIX Market, no período de 2003 a 2010 e constataram que as cooperativas de microfinanciamento têm retornos crescentes de escala, o que significa que a grande maioria pode reduzir custo, se eles se tornam maiores. Mersland e Strøm (2008) também estudaram o desempenho de cooperativas microfinanceiras e afirmaram que o desempenho das cooperativas de microfinanciamento estava entre os menos estudados e justificaram a importância de estudos a respeito deste segmento ressaltando que as cooperativas de crédito são as organizações mais antigas no setor de microfinanças.

No Brasil, o reconhecimento da importância das cooperativas de crédito para as microfinanças foi feito pela própria legislação, a exemplo da Lei do PNMPO - Lei 11.110/05 (Brasil, 2005), que as incluiu como instituições operadoras de microcrédito produtivo orientado.

\subsection{A Regulação}

A regulação econômica surge das críticas ao pensamento econômico neoclássico que preconiza que o mercado é autorregulável, e, portanto, qualquer regulação é totalmente desnecessária. Para os economistas neoclássicos, a máxima intervenção permitida é a de supervisão dos agentes econômicos; e a regulação é admitida apenas para dirimir ou eliminar as ineficiências geradas pelas falhas de mercado. Nesse setor, um forte argumento próregulação, além das imperfeições de mercado, diz respeito aos riscos (sistêmico, moral e risco de crédito). 
Nesse sentido, a regulação do mercado financeiro, além de proteger o sistema como um todo evitando, por exemplo, a falência de instituições (risco sistêmico), busca oferecer maior proteção aos agentes econômicos (credores e devedores) de ações oportunistas (risco moral).

Uma regulação bem planejada pode contribuir para a redução de eventos que possam comprometer a estabilidade do sistema financeiro (Stiglitz, 1993). Para o autor, os argumentos que defendem a liberalização do mercado financeiro são de caráter ideológico, sem fundamentação teórica, dadas as imperfeições desse mercado.

\subsubsection{Teoria da regulação}

A teoria da regulação surge na economia, inicialmente, sendo adaptada para outras áreas do conhecimento incluindo a Contabilidade. Segundo Biggar (2011), a partir do final dos anos 1950, até o início dos anos 1970, economistas da Universidade de Chicago produziram uma série de artigos criticando todas as formas de regulação econômica, sendo o primeiro trabalho mais importante o de Stigler (1971). Ainda de acordo com Biggar (2011), a visão mais comum na época era de que a intervenção do governo se orientava, mormente, para a correção de certas falhas de mercado.

A ideia de que a regulamentação não era uma força exógena, dirigida para o bem público sendo considerada endógena ao sistema econômico e potencialmente dirigida aos interesses econômicos de grupos, foi apresentada por Stigler (1971). O autor acrescenta que a existência de falhas de mercado é suficiente para gerar uma demanda por regulação.

O pressuposto de que a regulação decorre de supostas falhas de mercado e surge porque as transações econômicas geram externalidades tanto positivas quanto negativas, assim como estão sujeitas à assimetria informacional também é defendido por Stiglitz e Walsh (2003).

A teoria da regulação divide-se em teoria do interesse público e teoria do interesse privado. Esta última, discutida por Posner (1974), é conhecida também como teoria de captura, a qual assegura que a regulação serve aos interesses de grupos. Segundo Den Hertog (2010), a teoria do interesse privado surge após a teoria do interesse público cair em descrédito tanto empírica como teoricamente.

Essa divisão da teoria da regulação é debatida também por Scott (2012), o qual ressalta o seguinte: a teoria do interesse público admite que a regulação deve maximizar o bem-estar social, e a teoria da regulação dos grupos de interesse (teoria do interesse privado) 
salienta que os indivíduos formam coalizões para protegerem e promoverem os próprios interesses. De acordo com a teoria do interesse público, a regulação seria uma resposta à demanda do público para as falhas de mercado. Essa teoria maximizaria o bem-estar social na medida em que o regulador, por suposto, representa os melhores interesses da sociedade. Nesta perspectiva, a regulação gera um trade-off entre os custos e benefícios sociais, sendo esta teoria um ideal de como a regulação deve ser realizada. A despeito disso, a teoria do interesse público também apresenta problemas tais como a necessidade de o regulador decidir sobre a quantidade certa de regulação, além da motivação do regulador. Não obstante, as duas teorias (do interesse público e do interesse privado) estão interligadas (Scott, 2012).

De maneira geral, a regulação pode ser vista como um processo de emissão de normas. Nesta perspectiva, Pohlmann e Alves (2012) consideram que a regulação envolve a legitimidade do emissor das normas, a qualidade das normas, a aceitação ou eficácia das normas, os efeitos das normas, a utilidade das normas e a pertinência ou necessidade delas.

Referindo-se especificamente à regulação do sistema financeiro, esta considera dois importantes tipos, a saber: o prudencial e o não prudencial. A regulação prudencial decorre do risco sistêmico, denominado por Kumar (2004) de regulação protetora. Esse tipo de regulação diz respeito à proteção dos depositantes e exige supervisão do Estado ou de uma instituição reguladora e/ou supervisora. Saliente-se que o não prudencial é proveniente do risco de crédito e do risco moral, definido por Kumar (2004) como regulação capacitadora ou preventiva, e refere-se à divulgação, controle, proteção ao consumidor, desempenho financeiro etc.

A regulação é prudencial quando objetiva especificamente a proteção do sistema financeiro na totalidade deste, assim como busca proteger os pequenos depósitos de pequenas instituições (Consultative Group to Assist the Poorest [CGAP], 2002). Destarte, a regulação prudencial envolve governo e é muito mais complexa, difícil e dispendiosa do que a regulação não prudencial.

Regulação e supervisão, por vezes, são tomadas como sinônimos. Vogel, Gomez e Fitzgerald (1999) diferenciam esses conceitos definindo supervisão como o controle externo que visa determinar e fazer cumprir em conformidade com a regulamentação.

Isto posto, a regulação refere-se às regras que regem o comportamento das instituições financeiras, enquanto a supervisão é a fiscalização que busca assegurar que as instituições financeiras cumpram com essas regras. 


\subsubsection{Regulação de Microfinanças}

A regulação de instituições de microfinanças assemelha-se à regulação das demais instituições financeiras, com algumas especificidades em função das características das IMFs já discutidas.

Em relação às ferramentas utilizadas na regulação de IMFs também não diferem muito das tradicionalmente utilizadas em outras instituições financeiras. Jansson e Wenner (1997) afirmam que boa parte dos instrumentos utilizados para regular as instituições financeiras tradicionais é aplicada às instituições de microfinanças, e os instrumentos que mais podem influenciar a atividade das IMFs são: (a) controles prudenciais, (b) controles protecionistas e (c) controles estruturais. Os controles prudenciais, ainda segundo os autores, são a adequação do capital, o estabelecimento de provisões para devedores duvidosos e a documentação; já os controles protecionistas limitam-se à Lei da Usura ${ }^{9}$; e os controles estruturais são as barreiras à entrada dos grupos solidários como alternativa à ausência de garantias.

No caso da regulamentação e supervisão de microfinanças, existe um consenso no debate internacional em relação a alguns aspectos: um deles é que as IMFs que oferecem apenas crédito, “... em geral não necessitam estar sujeitas à regulamentação de prudência, devido aos recursos limitados de uma autoridade bancária para regulamentar e supervisionar uma instituição na qual o interesse público não está em jogo" (Kumar, 2004, p. 172).

Alguns autores, a exemplo de Vogel et al. (1999) defendem que regulação e supervisão prudencial devem ser aplicadas apenas às instituições de microfinanças que captam depósitos, por oferecerem maior risco ao público que deposita seus recursos. Assim, as que não recebem depósitos não deveriam ser regulamentadas, com exceção das leis gerais que tratam de fraude.

A maioria das IMFs enfrenta alguma forma de regulação não prudencial que inclui, por exemplo, regras que regem a formação destas, a defesa do consumidor (no caso o tomador do empréstimo), prevenções à fraude, a criação de sistemas de informação de crédito, operações de seguros, limites de taxa de juros, limites de propriedade estrangeira, além de questões fiscais e contábeis (Cull et al., 2008). Já a Regulação prudencial, segundo esses autores, é menos comum e é imposta quando as preocupações com o sistema (risco sistêmico) ou com a proteção de pequenos depositantes passam a ser um problema.

\footnotetext{
9 Denominação informal referente ao Decreto n⿳⺈ 22.626, de 7 de abril de 1933, que limitou a taxa de juros contratuais a $12 \%$ ao ano e proibiu o cálculo de juros sobre juros. Essa regulamentação não se aplica às instituições integrantes do Sistema Financeiro Nacional.
} 
Regulação, para Christen, Lyman e Rosenberg (2003), refere-se a um conjunto de regras vinculativas que regem a conduta de pessoas físicas e jurídicas, sejam elas adotadas por um órgão legislativo (leis) ou um órgão executivo (regulamentos). Complementam os autores que o governo não é a única instituição reguladora possível, pois existe também a autorregulação.

Já regulamento, conforme Lauer e Staschen (2013), é um termo usado para se referir a diferentes tipos de forma legal, decretos e pronunciamentos por parte do governo, e isto inclui a legislação primária (isto é, leis aprovadas pelo Legislativo), o direito derivado (isto é, circulares, regulamentos ou orientações emitidas ou adotadas pelo regulador), decretos e outros similares. Os autores definem supervisão como um termo mais frequentemente usado para se referir à supervisão prudencial dos bancos e outras instituições de captação de depósitos, embora se possa também incluir a supervisão de instituições que não captam depósitos, sendo o principal objetivo da supervisão bancária (ou prudencial) promover a segurança e a solidez dos bancos e do sistema bancário.

Em relação aos objetivos da regulação, ainda de acordo com Lauer e Staschen (2013), são ou diretamente destinados a remover estas falhas de mercado (por exemplo, exigências de divulgação que podem mitigar os problemas de assimetria de informação), ou destinam-se a aliviar as consequências negativas de falhas de mercado (por exemplo, proteção do cliente). Esses teóricos afirmam ainda que os principais tipos de regulação em microfinanças são a regulação prudencial - segurança e solidez de IMFs - e a não prudencial.

Quanto aos estudos já realizados sobre regulação de microfinanças, há os que tratam da necessidade ou não de regular, e também outros que analisam os efeitos da regulação. Existem, ainda, os que estudaram a relação entre regulação e desempenho de IMFs (Cull et al., 2008; Hartarska, 2005; Hartarska \& Nadolnyak, 2007), de modo que todos eles debruçaram-se sobre essas pesquisas.

Hartarska (2005) estudou os efeitos da regulação nas IMFs na Europa Central e Oriental e também nos Novos Estados Independentes e concluiu que instituições de microfinanças têm menor retorno dos ativos em relação a outras instituições. A autora encontrou evidências estatísticas de que sistemas bancários de regulação e de classificação não têm um impacto significativo sobre o desempenho de IMFs. Desse modo, ela encontrou também fraca evidência de que a amplitude do alcance pode estar relacionada à regulação. No entanto, a autora chama a atenção para o fato de que os resultados devem ser tomados com cautela, pois o número de observações é baixo para as estimativas de dados em painel realizadas na pesquisa. 
Hartarska e Nadolnyak (2007) estudaram o impacto da regulamentação sobre a autossuficiência operacional e o alcance de 114 IMFs de 62 países. Incluem-se no modelo variáveis de controle macroeconômicas e institucionais, bem como características específicas de cada banco, o que trouxe evidências empíricas de que a regulamentação das IMFs não lhe afeta diretamente o sucesso econômico, quer seja em termos de autossuficiência operacional, quer seja de alcance.

Utilizando dados $M I X$, os quais foram cruzados com informações de outros sites, Cull et al., 2008) investigaram o impacto da regulação prudencial sobre a rentabilidade e a autossustentabilidade financeira das instituições de microfinanças. A análise dos referidos autores baseou-se em informações de 346 IMFs em 67 países em desenvolvimento. Os resultados sugerem que as IMFs, submetidas à mais rigorosa supervisão regular, não são menos rentáveis em relação às demais, a despeito dos custos mais altos de supervisão.

Outro estudo relacionado é o de Pati (2012), o qual - usando dados de 40 IMFs para os anos de 2005-2006 e 2009-2010, a fim de analisar o efeito da regulação sobre a autossuficiência operacional e a rentabilidade das instituições, contrariamente à expectativa encontrou que a regulação não impactou a sustentabilidade nem a rentabilidade.

No Brasil, Silva (2012) fez uma análise qualitativa (da legislação e regulamentação) e quantitativa do quadro jurídico das microfinanças. Os achados sugeriram resultados mistos em termos de impacto do quadro jurídico e regulamentar então em vigor. Por um lado, a autorização de novos tipos de entidades e o estabelecimento de programas de microcrédito específicos tiveram um impacto positivo, por outro, as estritas regras têm limitado o crescimento da maioria das instituições de microfinanciamento, e o segmento desenvolveu uma forte dependência do financiamento público.

A Figura 3 apresenta um resumo dos principais estudos analisados sobre regulação de microfinanças. 


\begin{tabular}{|c|c|c|c|}
\hline Autores & Metodologia & \begin{tabular}{|l} 
Fonte de dados \\
\end{tabular} & $\begin{array}{lc}\text { Conclusões } \\
\end{array}$ \\
\hline Bogan (2012) & $\begin{array}{l}\text { Regressão com dados em } \\
\text { painel, efeitos fixos }\end{array}$ & $\begin{array}{l}\text { MIX Market, } 185 \text { IMFs da África, Ásia, } \\
\text { Europa Oriental, América Latina, } \\
\text { Oriente Médio e Sul da Ásia para os } \\
\text { anos de } 2003 \text { e } 2006 .\end{array}$ & $\begin{array}{l}\text { Encontrou evidências (relação causal) de que a utilização de subvenções, a longo } \\
\text { prazo, diminui a autossuficiência operacional de IMFs. }\end{array}$ \\
\hline $\begin{array}{l}\text { Cozarenco e Szafarz } \\
(2014)\end{array}$ & $\begin{array}{l}\text { Experimento natural, } \\
\text { utilizando um modelo } \\
\text { probit de diferenças em } \\
\text { diferenças }\end{array}$ & $\begin{array}{l}\text { A amostra é composta de } 1.097 \\
\text { contratos de crédito. O período de } 2008 \\
\text { a } 2012 \text { (o evento ocorreu em 2009) foi } \\
\text { dividido em dois subperíodos, cada um } \\
\text { caracterizado por um estatuto } \\
\text { regulamentar específico. }\end{array}$ & $\begin{array}{l}\text { Analisaram a conversão de uma ONG francesa de microcrédito não regulamentada } \\
\text { em uma IMF regulada (ocorrido em 2009), mais especificamente, o impacto dos } \\
\text { tetos de empréstimos na "fuga da missão". Os resultados mostraram que a } \\
\text { imposição de limites de empréstimo para as IMFs pode ter consequências } \\
\text { inesperadas e socialmente prejudiciais e desencadeia a "fuga da missão". }\end{array}$ \\
\hline Silva (2012) & $\begin{array}{l}\text { Análise qualitativa (da } \\
\text { legislação e } \\
\text { regulamentação) e } \\
\text { quantitativa }\end{array}$ & $\begin{array}{l}\text { Banco Mundial, Banco Central do Brasil } \\
\text { (BCB) e Instituto de Pesquisa } \\
\text { Econômica Aplicada (IPEA). }\end{array}$ & $\begin{array}{l}\text { Os achados sugerem resultados mistos em termos de impacto do quadro jurídico e } \\
\text { regulamentar em vigor em microfinanças no Brasil. Por um lado, a autorização de } \\
\text { novos tipos de entidades e o estabelecimento de programas de microcrédito } \\
\text { específicos tiveram um impacto positivo, por outro, as estritas regras têm limitado o } \\
\text { crescimento da maioria das instituições de microfinanciamento, e o segmento } \\
\text { desenvolveu uma forte dependência do financiamento público. }\end{array}$ \\
\hline $\begin{array}{l}\text { Trujillo, Rodriguez- } \\
\text { Lopez e Muriel-Patino } \\
(2014)\end{array}$ & Correlação de Spearman & $\begin{array}{l}\text { Dados fornecidos por autoridades } \\
\text { financeiras nos casos de carteira de } \\
\text { microcrédito ou instituições prestadoras } \\
\text { de microfinanciamento no setor } \\
\text { regulado. }\end{array}$ & $\begin{array}{l}\text { Correlações encontradas entre as variáveis quantitativas e qualitativas são } \\
\text { compatíveis com a ideia de que a fixação de um marco regulatório específico para } \\
\text { microfinanças é importante para o desenvolvimento da indústria, especialmente a } \\
\text { implementação de critérios de "proteção" "geral". Encontraram correlação positiva } \\
\text { e significativa em relação a alcance, rentabilidade, eficiência e qualidade da carteira } \\
\text { das instituições de microfinanças. Os resultados não são apropriados para afirmar a } \\
\text { superioridade de um determinado conjunto de categorias de regulação ou de um } \\
\text { determinado projeto de regulamentação de país, nem mesmo para excluir algumas } \\
\text { categorias de regulação (como promoção ou regras específicas). Apenas destacam a } \\
\text { importância da proteção e das regras gerais para o desempenho institucional e o } \\
\text { desenvolvimento da indústria. }\end{array}$ \\
\hline
\end{tabular}

Figura 3: Quadro Síntese dos Estudos sobre Regulação de Microfinanças e Microcrédito.

Fonte: Elaboração própria. 


\subsubsection{Regulação das Microfinanças e do Microcrédito no Brasil}

As primeiras experiências de concessão de microcrédito no Brasil são caracterizadas pela ausência da participação do Estado, seja na regulamentação da atividade, seja na inclusão dos pobres ao sistema formal de crédito (Braga, 2011). Conforme a autora, é somente na segunda metade dos anos 1990 que surgem algumas experiências pontuais de regulamentação com os programas de microcrédito que passam a vigorar como tema prioritário na esfera do Governo Federal, uma vez que o apoio ao setor surge como uma estratégia para reduzir a taxa de desemprego e a exclusão social.

Assim, o ponto de partida para a atuação do Estado no setor de microfinanças é a disponibilização de recursos financeiros para as ONGs atuantes na área de microcrédito, voltando-se posteriormente para a construção de um ambiente institucional relacionado às microfinanças por meio da criação de instituições específicas, a exemplo das Sociedades de Microcrédito (SCMs), bem como da disponibilização de recursos, a exemplo do uso do Fundo de Amparo ao Trabalhador (FAT) para o microcrédito produtivo.

Desde então as ações para concessão de crédito a pequenos empreendimentos se intensificaram. Entre algumas iniciativas estatais, destacam-se o Programa de Geração de Emprego e Renda (PROGER) - instituído em 1994 - e o Programa de Crédito Produtivo Popular (PCPP) - instituído em 1996, em sintonia com o Conselho do programa Comunidade Solidária $^{10}$-, ambos financiados com recursos do FAT (Braga, 2011).

A partir de 2002, as principais medidas para o segmento de microcrédito no Brasil podem ser assim resumidas (www.mte.gov.br):

○ Lei $n^{0}$ 9.790/90 (Brasil, 1999), mais conhecida como Lei das OSCIPs, permitiu a atividade de microcrédito a estas organizações;

○ Lei $\mathrm{n}^{\mathrm{o}}$ 10.735, de 11 de setembro de 2003 (Brasil, 2003) - estimulou a bancarização para a população de baixa renda e instituiu a obrigatoriedade de direcionamento de $2 \%$ dos depósitos à vista ao microcrédito, sob pena de serem recolhidos compulsoriamente ao BCB. Para Barone e Sader (2008), essa lei estabeleceu uma forte regulamentação sobre os valores de crédito e seus respectivos prazos, além de fixar as taxas de juros e regulamentar a profissão dos agentes de crédito. Essa lei também conferiu ao Conselho Monetário Nacional

\footnotetext{
${ }^{10}$ Programa criado em 1995 pelo governo federal brasileiro encerrado em dezembro de 2002, quando foi então substituído pelo Programa Fome Zero. O programa Fome Zero foi criado em 2003, em substituição ao Programa Comunidade Solidária, com o objetivo de combater a fome e a miséria.
} 
$(\mathrm{CMN})$ a competência para regulamentar as aplicações dos bancos comerciais, dos bancos múltiplos com carteira comercial, da Caixa Econômica Federal (CEF) e das cooperativas de crédito em operações de microfinanças destinadas à população de baixa renda, com recursos oriundos dos depósitos à vista;

- Lei $\mathrm{n}^{\mathrm{o}}$ 11.110, de 25 de abril de 2005 (Brasil, 2005) - institui o Programa Nacional de Microcrédito Produtivo Orientado - PNMPO;

○ Lei $\mathrm{n}^{\mathrm{o}}$ 12.666/2012 (Brasil, 2012), regulamentou o CRESCER, Programa Nacional de Microcrédito.

A despeito do avanço na regulamentação do microcrédito no Brasil, Braga (2011) considera que ainda não é possível um direcionamento adequado de recursos públicos para o microcrédito, tampouco são incentivados investimentos do setor privado, o que contribui para o pequeno desenvolvimento do segmento. A Figura 4 sintetiza os Decretos, Leis e Resoluções discutidos nesta seção. 


\begin{tabular}{|c|c|c|}
\hline Decreto/Lei/Resolução & Nome/Título & O que regulamentou \\
\hline $\begin{array}{l}\text { Lei } \mathrm{n}^{\mathrm{o}} 5.764 \text {, de } 16 \text { de dezembro } \\
\text { de } 1971 \text { (Brasil, 1971) }\end{array}$ & Lei do Cooperativismo. & \\
\hline $\begin{array}{l}\text { Lei } \mathrm{n}^{\mathrm{o}} 7.998, \text { de } 1990 \text { (Brasil, } \\
\text { 1990). }\end{array}$ & $\begin{array}{l}\text { Criou o Fundo de Amparo ao Trabalhador (FAT) e seu Conselho } \\
\text { Deliberativo (Codefat). }\end{array}$ & \\
\hline $\begin{array}{l}\text { Lei }{ }^{0} \text { 8.019, de } 11 \text { de abril de } \\
1990 \text { (Brasil,1990a) }\end{array}$ & $\begin{array}{l}\text { Altera a legislação do Fundo de Amparo ao Trabalhador (FAT), e } \\
\text { dá outras providências }\end{array}$ & \\
\hline $\begin{array}{l}\text { Lei } \mathrm{n}^{\mathrm{o}} 9.790, \text { de } 23 \text { de março de } \\
1999 \text { (Brasil, 1999) }\end{array}$ & $\begin{array}{l}\text { Dispõe sobre a qualificação de pessoas jurídicas de direito privado, } \\
\text { sem fins lucrativos, como Organizações da Sociedade Civil de } \\
\text { Interesse Público (OSCIPs), institui e disciplina o Termo de } \\
\text { Parceria, e dá outras providências. }\end{array}$ & Criou a figura jurídica da OSCIP. \\
\hline $\begin{array}{l}\text { Decreto } \mathrm{n}^{\mathrm{o}} 3.100, \text { de } 1999 \\
\text { (Brasil, 1999a) }\end{array}$ & $\begin{array}{l}\text { Qualificação das OSCIPs como organizações particulares de } \\
\text { direito privado e interesse público, sem fins lucrativos e } \\
\text { fiscalizadas pelo Poder Público, mediante vínculo jurídico } \\
\text { instituído por meio de termo de parceria. }\end{array}$ & Regulamentou a Lei n⿳0 9.790/99 - Lei do terceiro Setor (Brasil, 1999). \\
\hline $\begin{array}{l}\text { Resolução do } \mathrm{BCB} \mathrm{n}^{\mathbf{0}} 2.627 \text {, de } \\
1999 \text { (Banco Central do Brasil } \\
\text { [BCB], 1999) }\end{array}$ & & Regulamentou as SCMs. \\
\hline $\begin{array}{l}\text { Lei } \mathrm{n}^{\mathrm{o}} \text { 10.194, de 2001(Brasil, } \\
\text { 2001) }\end{array}$ & $\begin{array}{l}\text { Criou as SCMs sujeitas à fiscalização do BCB e as definiu como } \\
\text { instituições financeiras não bancárias, cujo objeto social é a } \\
\text { concessão de financiamentos a pessoas físicas e a microempresas. }\end{array}$ & \\
\hline $\begin{array}{l}\text { Resolução do } \mathrm{BCB}^{\mathrm{o}} 3.058 \text {, de } \\
20 \text { de dezembro de } 2002 \text { (Banco } \\
\text { Central do Brasil }[\mathrm{BCB}], 2002)\end{array}$ & & $\begin{array}{l}\text { Autorizou a criação de cooperativas de pequenos empresários, } \\
\text { microempresários e microempreendedores, proprietários de negócios de } \\
\text { natureza industrial, comercial ou de prestação de serviços, compreendendo } \\
\text { também as atividades da área rural. }\end{array}$ \\
\hline $\begin{array}{l}\text { Lei } \mathrm{n}^{\mathrm{o}} 10.735 \text {, de } 11 \text { de } \\
\text { setembro de } 2003 \text { (Brasil, 2003) }\end{array}$ & & $\begin{array}{l}\text { Determinou que as instituições financeiras (bancos comerciais, bancos } \\
\text { múltiplos com carteira comercial, Caixa Econômica Federal, cooperativas de } \\
\text { crédito de pequenos empresários, microempresários ou microempreendedores } \\
\text { e de livre admissão de associados) deveriam aplicar em operações de crédito } \\
\text { destinadas à população de baixa renda e a microempreendedores parcela dos } \\
\text { recursos oriundos dos depósitos à vista por eles captados (Art. } 1^{\underline{o}} \text { ). }\end{array}$ \\
\hline $\begin{array}{l}\text { Resolução do } \mathrm{BCB}^{\mathrm{0}} \text { 3.106/03 } \\
(\mathrm{BCB}, 2003)\end{array}$ & & $\begin{array}{l}\text { Permitiu a criação de cooperativas de crédito de livre admissão (tipo Luzzatti) } \\
\text { e a transformação das cooperativas de crédito existentes nesta nova } \\
\text { modalidade. }\end{array}$ \\
\hline $\begin{array}{l}\text { Resolução do } \mathrm{BCB} \mathrm{n}^{\mathrm{o}} 3.109 \text {, de } \\
24 \text { de julho de } 2003 \text { (Banco }\end{array}$ & & $\begin{array}{l}\text { Determinou que dois por cento dos saldos dos depósitos à vista das } \\
\text { instituições financeiras deveriam ser aplicados em operações de microcrédito }\end{array}$ \\
\hline
\end{tabular}




\begin{tabular}{|c|c|c|}
\hline Decreto/Lei/Resolução & Nome/Título & O que regulamentou \\
\hline Central do Brasil [BCB], 2003a) & & $\begin{array}{l}\text { - atendidas as condições referentes ao perfil do tomador, com limitação das } \\
\text { taxas de juros e da TAC (Taxa de Abertura de Crédito) efetivas a dois por } \\
\text { cento ao mês. }\end{array}$ \\
\hline $\begin{array}{l}\text { Lei } n^{0} 11.110, \text { de } 25 \text { de abril de } \\
2005 \text { (Brasil, 2005) }\end{array}$ & 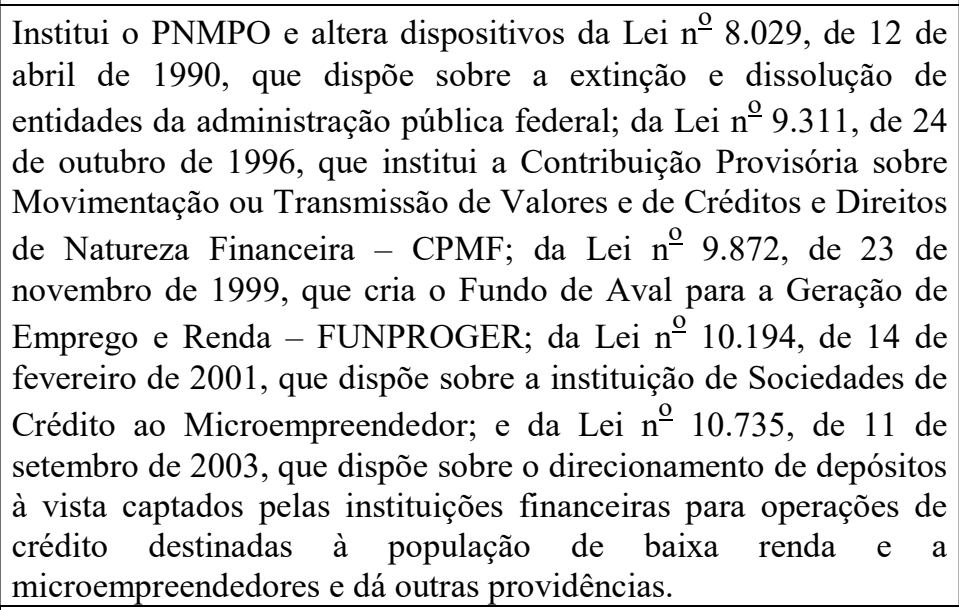 & \\
\hline $\begin{array}{l}\text { Resolução do BCB n⿳0 } 3.442, \\
28 / 02 / 2007^{11}\end{array}$ & $\begin{array}{l}\text { Dispõe sobre a constituição e o funcionamento de cooperativas de } \\
\text { crédito. }\end{array}$ & $\begin{array}{l}\text { Às cooperativas foi permitido: } \\
\text { captar, somente de associados, depósitos sem emissão de certificado; } \\
\text { obter empréstimos ou repasses de instituições financeiras nacionais ou } \\
\text { estrangeiras e de fundos oficiais; } \\
\text { ○ conceder créditos e prestar garantias, somente a associados; } \\
\text { aplicar recursos no mercado financeiro, inclusive em depósitos à vista, } \\
\text { depósitos a prazo e depósitos interfinanceiros, observadas eventuais } \\
\text { restrições legais e regulamentares específicas de cada aplicação; } \\
\text { proceder à contratação de serviços com o objetivo de viabilizar a } \\
\text { compensação de cheques e as transferências de recursos no sistema } \\
\text { financeiro; } \\
\text { prestar os seguintes serviços, visando atendimento a associados e a não } \\
\text { associados: cobrança, custódia e recebimentos e pagamentos por conta de } \\
\text { terceiros, entidades públicas ou privadas; distribuição de cotas de fundos } \\
\text { de investimento administrados por instituições autorizadas, observada, } \\
\text { inclusive, a regulamentação aplicável editada pela CVM; correspondentes } \\
\text { no país. }\end{array}$ \\
\hline
\end{tabular}

${ }^{11}$ Esta Resolução foi revogada pela Resolução do BCB nº 3.859, de 27/5/2010. 


\begin{tabular}{|c|c|c|}
\hline Decreto/Lei/Resolução & \begin{tabular}{|c|} 
Nome/Título \\
\end{tabular} & O que regulamentou \\
\hline $\begin{array}{l}\text { Decreto } \mathrm{n}^{\mathrm{o}} 6.607, \text { de } 21 \text { de } \\
\text { outubro de } 2008 \text { (Brasil, 2008) }\end{array}$ & $\begin{array}{l}\text { Dá nova redação ao art. } 3^{\underline{0}} \text { do Decreto } \mathrm{n}^{0} \text { 5.288, de } 29 \text { de } \\
\text { novembro de } 2004 \text {, que dispõe sobre o PNMPO. }\end{array}$ & O limite de faturamento anual foi elevado para 120 mil reais \\
\hline $\begin{array}{l}\text { Resolução do } \mathrm{BCB} \mathrm{n}^{\mathrm{o}} 3.859 \text {, de } \\
\text { 27/05/2010 (Banco Central do } \\
\text { Brasil [BCB], 2010) }\end{array}$ & $\begin{array}{l}\text { Altera e consolida as normas relativas à constituição e ao } \\
\text { funcionamento de cooperativas de crédito. }\end{array}$ & \\
\hline $\begin{array}{l}\text { Resolução do } \mathrm{BCB}^{\mathrm{o}} 4.000, \text { de } \\
25 \text { de agosto de } 2011 \text { (BCB, } \\
\text { 2011) }\end{array}$ & $\begin{array}{l}\text { Altera e consolida as normas que dispõem sobre a realização de } \\
\text { operações de microcrédito destinadas à população de baixa renda e } \\
\text { a microempreendedores. }\end{array}$ & $\begin{array}{l}\text { Determinou que } 80 \% \text { da exigibilidade destinada ao microcrédito fosse } \\
\text { destinada para o microcrédito produtivo orientado, com o limite de quinze mil } \\
\text { reais para o crédito concedido nessa modalidade. }\end{array}$ \\
\hline $\begin{array}{l}\text { Resolução do } \mathrm{BCB} \mathrm{n}^{\mathrm{O}} 4.152, \text { de } \\
2012 \text { (Banco Central do Brasil } \\
[\mathrm{BCB}], 2012)\end{array}$ & & $\begin{array}{l}\text { Definição mais clara de microcrédito, porém ainda abrangente, com foco } \\
\text { no valor e na metodologia de avaliação dos riscos da operação quanto à } \\
\text { inadimplência. } \\
\text { Limitou o endividamento total ao tomador de microcrédito em geral a } \\
\text { três vezes o valor do PIB per capita. }\end{array}$ \\
\hline $\begin{array}{l}\text { Lei } \mathrm{n}^{\mathrm{o}} \text { 12.666/2012 (Brasil, } \\
\text { 2012) }\end{array}$ & Criou o CRESCER - Programa Nacional de Microcrédito & $\begin{array}{l}\text { Criou subvenção econômica limitado inicialmente em } 500 \text { milhões de reais } \\
\text { por ano; Limitou a taxa de juros para o MPO, inicialmente em } 8 \% \text { a.a. para o } \\
\text { tomador final. }\end{array}$ \\
\hline $\begin{array}{l}\text { Lei } \mathrm{n}^{\underline{\mathrm{o}}} 12.613 \text {, de } 18 \text { de abril de } \\
2012 \text { (Brasil, 2012a) }\end{array}$ & $\begin{array}{l}\text { Altera a Lei } \mathrm{n}^{\mathrm{o}} 10.735 / 2003 \text {, que dispõe sobre o direcionamento de } \\
\text { depósitos à vista captados pelas instituições financeiras para } \\
\text { operações de crédito destinadas à população de baixa renda e a } \\
\text { microempreendedores, e dá outras providências. }\end{array}$ & \\
\hline $\begin{array}{l}\text { Resolução do } \mathrm{BCB}^{\mathrm{o}} 4.153 \text {, de } \\
30 \text { de outubro de } 2012(\mathrm{BCB}, \\
2012 \mathrm{a})\end{array}$ & $\begin{array}{l}\text { Altera a Resolução } \mathrm{n}^{\mathbf{0}} 4.000 / 2011 \text {, que dispõe sobre a realização } \\
\text { de operações de microcrédito destinadas à população de baixa } \\
\text { renda e a microempreendedores. }\end{array}$ & $\begin{array}{l}\text { Limitou o endividamento em operações de microcrédito produtivo orientado } \\
\text { ao teto de quarenta mil reais. }\end{array}$ \\
\hline $\begin{array}{l}\text { Resolução do } \mathrm{BCB}^{\underline{0}} 4.242 \text {, de } \\
28 \text { de junho de } 2013 \text { (BCB, } \\
\text { 2013) }\end{array}$ & & $\begin{array}{l}\text { Altera a Resolução } \mathrm{n}^{\underline{0}} 4.000 / 2011 \text {, que dispõe sobre o direcionamento de } \\
\text { depósitos à vista captados pelas instituições financeiras para operações de } \\
\text { crédito destinadas à população de baixa renda e a microempreendedores. }\end{array}$ \\
\hline $\begin{array}{l}\text { Portaria } \mathrm{n}^{\mathbf{0}} 411 \text {, do Ministério } \\
\text { da Fazenda, de } 10 \text { de julho de } \\
2013 \text { (Brasil, 2013) }\end{array}$ & & Reduziu a taxa de juros do CRESCER para $5 \%$ a.a. \\
\hline $\begin{array}{l}\text { Portaria } \mathrm{n}^{0} \text { 83, de } 21 \text { de março } \\
\text { de } 2014 \text { (Brasil, 2014) }\end{array}$ & & $\begin{array}{l}\text { Estabelece as condições para pagamento de equalização do Programa Crescer } \\
\text { no âmbito do PNMPO para o exercício de } 2014 \text {. }\end{array}$ \\
\hline
\end{tabular}

Figura 4: Quadro Síntese de Decretos, Resoluções e Leis.

Fonte: Elaboração própria com base nos respectivos Decretos, Resoluções e Leis. 


\subsection{Microfinanças e microcrédito no contexto das políticas de financiamento do desenvolvimento}

O desenvolvimento econômico ou a ausência dele passou a ser questão prioritária no contexto do pós-guerra quando grande parte dos países encontravam-se subdesenvolvidos. Assim, tanto os debates teóricos quanto as ações programáticas voltaram-se para o desenvolvimento de políticas de fomento ao desenvolvimento.

Nesse sentido, com o objetivo de ajuda à reconstrução dos países devastados pela Segunda Guerra Mundial foram criadas em 1944, algumas instituições multilaterais como o Banco Internacional para Reconstrução e Desenvolvimento (BIRD) - hoje parte do grupo do Banco Mundial ${ }^{12}$-, o Fundo Monetário Internacional (FMI), dentre outras. Após a reconstrução da Europa por volta de 1950, o objetivo destas organizações passou a ser apoiar e assistir os países subdesenvolvidos (Baer \& Lichtensztejn, 1987).

O financiamento do desenvolvimento ocorre, segundo Schmidit (2010), em três fases distintas: a primeira fase, que vai de 1950 até a primeira metade de 1970; a segunda fase, da segunda metade de 1970 até 1980 e a terceira, inicia-se nos anos 1990.

Durante a primeira fase, o financiamento do desenvolvimento consistia principalmente em transferências de capital em larga escala por meio de grandes linhas de financiamento para os bancos de desenvolvimento estatais em países subdesenvolvidos na expectativa de que o crescimento de grandes empresas e melhorias de infraestrutura melhoraria a situação da população em geral (Schmidt, 2010). Para o autor, essa estratégia não funcionou bem na maioria dos casos, pelo contrário, só alimentou um desenvolvimento dualista que fez amplos segmentos da população mais pobres.

Na segunda fase, ainda conforme Schmidt (2010), embora as transferências de capital tenham continuado, desta vez os fundos destinavam-se diretamente para os grupos-alvo: pobres e micro e pequenas empresas. Todavia, não havia tecnologia ou "canais" para fazer o recurso chegar até esse público. Segundo o autor, os bancos privados não pareciam ser veículos adequados porque faltava-lhes o conhecimento de como emprestar a microempreendedores e, além disso, as taxas de juros praticadas pelos países-alvo eram muito

\footnotetext{
12 Além do BIRD, compõem o World Bank Group mais quatro organizações: a International Development Association (IDA), que oferece empréstimos sem juros aos países mais pobres - juntos, o BIRD e a IDA formam o Banco Mundial; a International Finance Corporativo (IFC), que trabalha exclusivamente com os setores privados das economias; a Multilateral Investment Guarantee Agency (MIGA), que faz seguros contra riscos políticos (garantias) aos investidores e credores e o International Centre for Settlement of Investment Disputes (ICSID), que oferece mecanismos internacionais de conciliação e arbitragem de disputas sobre investimentos (www.worldbank.org).
} 
altas, o que inviabilizava qualquer banco de ofertar empréstimos muito pequenos. É quando as atenções se voltam para as ONGs, por constituírem-se em instituições não lucrativas e, assim, foram consideradas adequadas para esse propósito. Ocorre que a canalização de microempréstimos através de ONGs também não funcionou, principalmente porque estas organizações possuíam altos custos e baixo nível de profissionalismo, o que inviabilizou a sustentabilidade financeira (Schmidt, 2010). A partir de mais esse fracasso, tem início a terceira fase das políticas de financiamento do desenvolvimento.

A terceira fase é marcada pela estratégia encontrada na época para resolver o problema da falta de sustentabilidade das ONGs, qual seja, a "modernização" ou comercialização das ONGs (Schmidt, 2010) que consistia na transformação de ONGs em organizações lucrativas ou comercialmente orientadas. Durante os anos 1990, houve um aumento na criação de IMFs de orientação comercial notadamente na Ásia e na América Latina. Os exemplos mais importantes das microfinanças comerciais apontados por Schmidt (2010) são o Banco Sol na Bolívia e o Banco Compartamos, no México. Nos anos 1990 surgem ainda uma série de inovações nas tecnologias de microcrédito e na estrutura organizacional das IMFs, sendo que a mais importante delas foi a desenvolvida e aplicada pelo Grameen Bank, qual seja, o empréstimo em grupo.

O modelo adotado pelo Grameen baseia-se na crença de que o microcrédito pode substituir soluções ineficientes de governo e coincide com a redefinição estratégica das políticas de microcrédito do Banco Mundial. A ideia de fomentar um desenvolvimento com inclusão financeira dos pobres, por sua vez, é influenciada teoricamente, segundo Hume \& Mosley (1996), pelo pensamento da Universidade de Ohio, nos Estados Unidos. As principais contribuições da Escola de Ohio diz respeito às crenças na eficiência do mercado, em oposição às instituições financeiras criadas pelo Estado.

No Brasil, nesse mesmo contexto de mudança de agenda nas políticas de financiamento do desenvolvimento promovidas pelos organismos multilaterais que passaram a ter uma preocupação maior com a pobreza a partir dos anos 1970, surgem as primeiras experiências de microcrédito: a União Nordestina de Assistência a Pequenas Organizações (UNO) e o Programa Crediamigo, do Banco do Nordeste ambos apoiados pelo World Bank Group (Miguel, 2012). Nessa perspectiva, a indústria de microfinanças se desenvolveu consoante as políticas das agências multilaterais para o financiamento do desenvolvimento econômico. O programa Crediamigo, segundo Neri \& Medrado (2010), começou a operar em abril de 1998, com o objetivo de oferecer crédito rápido e com pouca burocracia a microempreendedores. Utiliza a metodologia do aval solidário e desenvolve um 
acompanhamento do empréstimo por um agente de crédito que atende os clientes no próprio local do empreendimento. Ainda segundo os autores, o programa cresceu a taxas superiores às de iniciativas semelhantes e em 2010, já era o maior programa de microcrédito produtivo do Brasil e o segundo maior da América Latina ofertando sozinho mais do que todos os outros programas juntos. O Crediamigo, embora desenvolvido e implementado por um banco estatal de desenvolvimento, o Banco do Nordeste, é administrado por uma OSCIP, a Instituto Nordeste Cidadania (INEC). Com o sucesso do Crediamigo, o Brasil se torna um modelo alternativo ao clássico: um modelo híbrido que mescla operações lucrativas e não lucrativas e onde operam diversos tipos de instituições financeiras e não financeiras juntamente com programas de governo em seus diversos níveis.

\subsubsection{As Políticas de microfinanças e de microcrédito no Brasil}

Historicamente, no Brasil, a participação do Estado no segmento de microcrédito e microfinanças tem se dado de múltiplas formas, a depender do tipo de governo e da sua orientação programática, ora intervindo de forma indireta, regulando o setor; ora por meio de participação mais ativa criando e implementando programas públicos ou ainda fornecendo funding para as organizações públicas, privadas e não governamentais (ONGs). Daí a necessidade de discutir o microcrédito tanto na perspectiva da regulação quanto na abordagem das políticas púbicas. Política pública, na contemporaneidade, pode ser compreendida como aquela que não apenas busca atender às demandas de grupos da sociedade, tanto em nível micro quanto em nível macroeconômico, mas sobretudo é a política que tem a participação da sociedade civil organizada nos seus três estágios: planejamento, execução e avaliação. Se essa política for decorrente de uma reivindicação da sociedade, é considerada como uma política genuinamente pública.

A Nova Economia Institucional (NEI) tem contribuído para o debate acerca das políticas públicas. Simon (1955), um dos expoentes da teoria institucional, introduziu o conceito de racionalidade limitada dos decisores públicos (policy makers) e asseverou que essa racionalidade limitada dos policy makers decorre da assimetria informacional e do auto interesse dos decisores, dentre outros fatores. Para Souza (2006), essa racionalidade limitada pode ser corrigida pela criação de estruturas (conjunto de regras e incentivos) que modelam o comportamento dos atores em direção a resultados desejados, impedindo, assim, a busca de maximização de interesses próprios. A autora acrescenta que outras abordagens da teoria neoinstitucionalista (como o institucionalismo histórico e o estruturalista) também contribuem 
para o debate sobre o papel das instituições na tomada de decisões dos policy makers. Para essas ramificações do neoinstitucionalismo, as decisões e ações de políticas públicas são mobilizadas não apenas pelo auto interesse, mas também por processos institucionais de socialização, considerando inclusive, novas ideias e processos gerados pela história de cada país. Essas visões são fundamentais para a compreensão das políticas públicas, em especial porque a teoria neoinstitucionalista ressalta que não são apenas os indivíduos ou grupos que têm força para influenciar políticas públicas, mas também as regras formais e informais que regem as instituições.

Em relação a avaliação de políticas públicas, não existe consenso quanto à sua definição pois, segundo Ala-Harja e Helgason (2000), trata-se de um conceito que admite múltiplas definições, algumas delas contraditórias. Os autores complementam que esse fato se explica justamente porque a área de politicas publicas transita por uma variedade de disciplinas, instituições e executores, abrangendo diversas questões, necessidades e pessoas.

A avaliação de política pública pode ser categorizada em avaliação de metas, avaliação de processos e avaliação de impacto, e sua operacionalização pode ser realizada pelo uso de indicadores (Costa \& Castanhar, 2003).

A avaliação de metas tem como propósito mensurar o grau de êxito que um programa alcança. A avaliação de processo tem como objetivo detectar problemas na elaboração dos procedimentos, além de acompanhar e avaliar a execução dos procedimentos de implantação dos programas ou políticas, identificando obstáculos à sua implementação e gerando dados para sua reprogramação. Já a avaliação de impacto focaliza os efeitos ou impactos produzidos sobre a sociedade, ou seja, avalia-se a sua efetividade social (Carvalho, 2003).

Quanto aos estágios da avaliação, pode ser classificada em ex-ante (anterior ao programa ou política), intermediária e ex-post (posterior). O primeiro tipo é, em geral, considerado como análise ou avaliação de politicas. Segundo Trevisan e Van Bellen (2008), a avaliação intermediária ou formativa é realizada durante o processo de implementação de um programa ou política visando melhorar a gestão do mesmo; a avaliação ex-post ou somativa, objetiva analisar impactos e processos investigando a eficácia e atribuindo juízo de valor ao programa/política.

No que toca à avaliação de impacto, Barros e Lima (2012) sustentam que o seu principal objetivo é verificar se, de fato, um determinado programa ou política está alcançando ou atingiu metas definidas. Os autores compreendem impacto como as diferenças entre a situação dos participantes de um determinado projeto ou situação após terem participado e a situação em que estariam, caso não o tivessem acessado. Dito de outra forma, 
é a comparação entre duas situações: uma real (posterior ao projeto ou evento) e outra hipotética (a situação em que estariam os participantes caso não tivessem tido a oportunidade de participar do programa/política). Complementam os autores que tão ou mais importante do que conhecer se há/houve algum impacto é saber a magnitude do impacto, como também conhecer quais as dimensões em que o programa tem impacto.

As avaliações de impacto são consideradas ainda como parte de uma agenda mais ampla de formulação de políticas baseadas em evidências, e com base nos Objetivos de Desenvolvimento do Milênio $^{13}$, as políticas públicas deixaram de ter foco não apenas em resultados, mas também na melhoria das políticas, ações e decisões políticas (Verter, Martinez, Premand, Rawlings \& Vermeersch, 2011). Nessa perspectiva, avaliações de impacto podem fornecer fortes evidências sobre o desempenho assim como se um determinado programa alcançou os objetivos traçados. Os autores afirmam ainda que avaliações de impacto são um tipo específico de avaliação que visa responder a perguntas de causa e efeito.

Por conseguinte, avaliação de impacto possui um elevado grau de complexidade, e no que tange às políticas de microcrédito no Brasil, a dificuldade é ainda maior em razão da pouca disponibilidade e baixa qualidade dos dados existentes. Assim, a proposta deste trabalho não é avaliar o impacto dos programas de microcrédito em questão, a saber, o PNMPO e o CRESCER, mas analisar os efeitos das mudanças regulatórias recentemente neles implementadas sobre o desempenho financeiro e social de cooperativas de crédito.

Referindo-se à avaliação de impacto de ações de microcrédito, Cacciamali, Chahad e Tatei (2008) a classificam como: Avaliação de impacto (Tipo I) e Análise de desempenho (Tipo II). A primeira visa captar os efeitos diretos do microcrédito sobre as variáveis em análise por meio da comparação de dados de um grupo de tomadores de empréstimo com outro grupo que não tomou empréstimo. A segunda é considerada pelos autores como um procedimento mais simples, uma vez que este procedimento compara o desempenho póscrédito de uma série de indicadores dos tomadores de empréstimo.

\footnotetext{
${ }^{13}$ Os Objetivos de Desenvolvimento do Milênio (ODM) é uma agenda global definida em 2000, pelos principais líderes mundiais tendo como o primeiro dos oitos objetivos erradicar a pobreza extrema e a fome. Em 2012, durante a Rio+20 - Conferência das Nações Unidas sobre Desenvolvimento Sustentável, realizada no Rio de Janeiro - esses objetivos foram substituídos por metas para o desenvolvimento sustentável e, a partir de 2015, surgiram os ODS (Objetivos de Desenvolvimento Sustentável) - conjunto de metas (17 objetivos) para redução da pobreza, promoção social e proteção ao meio ambiente a serem alcançadas até 2030. Para saber mais acesse http://www.objetivosdomilenio.org.
} 
A presente pesquisa efetua uma análise de desempenho de ações de microcrédito, porém não no âmbito do tomador e sim, na perspectiva do ofertante, a saber, as cooperativas de crédito que operam em todo o território brasileiro.

A política de microcrédito no Brasil é considerada por Miguel (2012), pelas suas características, como uma política pública que representa um projeto de caráter social instrumentalizada via mercado financeiro.

De maneira geral, as políticas públicas podem ser divididas em dois tipos: as compensatórias, também chamadas de políticas passivas - destinadas à proteção dos trabalhadores desempregados ou em faixas salariais mais baixas por meio de assistência financeira temporária -, e as políticas de investimento e acesso ao crédito, ou políticas ativas - visando ao aumento da capacidade produtiva da economia por meios da geração e manutenção de postos de trabalho (Bernardoni, Souza \& Peixe, 2008).

Como exemplos de políticas compensatórias, podem-se citar: seguro-desemprego, abono salarial, redução da jornada de trabalho, além de outros; e, como exemplos de políticas ativas, tem-se: formação profissional, apoio aos microempreendedores, incentivos à criação de empregos etc.

O PNMPO, embora seja um programa, pode ser considerado uma política ativa, tendo em vista que contempla diretrizes de financiamento de capital de giro e investimento, além de ações de capacitação (tanto dos tomadores quanto dos agentes de crédito) e de educação financeira. A diferença básica entre política e programa consiste na abrangência e duração dessas ações. Os programas são mais específicos, mais delimitados, e normalmente têm duração menor do que as políticas. Estas, por sua vez, são mais abrangentes e duradouras, sobretudo se forem políticas de Estado (ultrapassarem a gestão de um governo) em vez de políticas de governo.

As políticas públicas de microcrédito no Brasil, segundo Soares e Melo Sobrinho (2008), foram discutidas e elaboradas partindo-se de dois modelos: (a) o modelo desenvolvimentista, o qual defende que os programas de microcrédito devem ser orientados para o combate estrutural da pobreza. Neste modelo, as IMCs devem atuar como um agente de desenvolvimento social, fornecendo não apenas crédito, mas também capacitação técnica e gerencial; (b) o modelo minimalista, que prioriza a sustentabilidade das IMCs.

Com a criação da Lei das OSCIPs - Lei nº 9.790/99 (Brasil, 1999), as ONGs que se qualificaram como OSCIPs passaram a ter acesso a recursos públicos por meio da assinatura de termo de parceria. Em 2001, a Lei $\mathrm{n}^{\mathrm{o}}$ 10.194/01 (Brasil, 2001) criou as SCMs, organizações privadas, específicas de microcrédito e sujeitas à fiscalização do $\mathrm{BCB}$, sendo- 
lhes vedada a captação de recursos junto ao público (depósitos e poupança). Isto posto, a criação do PNMPO deu-se no âmbito do modelo desenvolvimentista.

\subsubsection{O Programa Nacional de Microcrédito Produtivo Orientado (PNMPO) e o CRESCER - Programa Nacional de Microcrédito}

Considerada a mais recente alteração institucional no setor de microfinanças brasileiro, o PNMPO é classificado pelo MTE como um programa de geração de emprego e renda. O referido programa foi criado no contexto da intensificação das ações de políticas de emprego no Brasil a partir dos anos 1960 a 1970 e é considerado tanto uma política econômica (objetiva gerar emprego e renda) como uma política social (tem como públicoalvo as camadas mais pobres da sociedade: desempregados, subempregados, trabalhadores por conta própria, microempreendedores individuais e microempresas).

De acordo com a Lei do PNMPO - Lei 11.110/2005 (Brasil, 2005), os objetivos do programa são: (a) incentivar a geração de trabalho e renda entre os microempreendedores populares; (b) disponibilizar recursos para o microcrédito produtivo orientado e; (c) oferecer apoio técnico às instituições de microcrédito produtivo orientado, com vistas ao fortalecimento institucional destas para a prestação de serviços aos empreendedores populares.

A coordenação do PNMPO é feita conjuntamente pelo MTE, Ministério do Desenvolvimento Scial (MDS) e Ministério da Fazenda. O MTE é responsável pela habilitação das organizações de microcrédito e pela coleta e disponibilização de informações sobre o microcrédito. O funding do programa é proveniente do Fundo de Amparo ao Trabalhador (FAT) e do uso compulsório de $2 \%$ dos depósitos à vista captados por bancos comerciais e cooperativas de crédito singulares no âmbito no sistema financeiro nacional Art. $1^{\circ}$. da Lei 10.735, de 11 de setembro de 2003 - (Brasil, 2003), alterado pela Lei 11.110, de 2005.

Para o MTE, microcrédito produtivo orientado é a concessão de crédito destinado a atividades produtivas de pequeno porte desenvolvidas por pessoas físicas e jurídicas, formais e informais, com renda bruta anual de até 120 mil. A lei prevê o acompanhamento da operação por um agente de crédito devidamente capacitado para essa função.

A concepção inicial do PNMPO, conforme Pereira (2007), baseou-se no trabalho até então realizado pela sociedade civil, inicialmente por meio de ONGs, Bancos do Povo e OSCIPs, e depois se incorporaram as Cooperativas de Crédito, as SCMs e outras, as quais 
apresentaram proposta ao governo. Esta proposta posteriormente se transformou em medida provisória, e mais adiante, em lei. $\mathrm{O}$ autor acrescenta ainda que a legislação do microcrédito produtivo orientado, criada a partir de 2004, estabeleceu um marco regulatório mínimo e, por consequência, criou um sistema para o microcrédito produtivo orientado.

Ainda conforme a Lei 11.110/2005 (Brasil, 2005), as Instituições Financeiras Operadoras (IFO) do programa são:

- Com os recursos do FAT: Banco do Brasil (BB), Caixa Econômica Federal (CEF), Banco do Nordeste, Banco da Amazônia, Banco Nacional de Desenvolvimento Econômico e Social (BNDES) - instituições financeiras oficiais de que trata a Lei $\mathrm{n}^{\mathrm{o}}$ 8.019, de 11 de abril de 1990 (Brasil, 1990a);

- Com a parcela dos recursos de depósitos à vista: os bancos comerciais, os bancos múltiplos com carteira comercial e a CEF (www.portalmte.gov.br).

As Instituições de Microcrédito Produtivo Orientado (IMPO) que podem participar do PNMPO são: cooperativas de crédito singulares, agências de fomento, Sociedades de Crédito ao Microempreendedor (SCMs) e Organizações da Sociedade Civil de Interesse Público (OSCIPs). Os Agentes de Intermediação (AGIs) ou instituições que atuam na intermediação dos recursos financeiros são os bancos de desenvolvimento, as agências de fomento, os bancos cooperativos e as cooperativas centrais de crédito. As Instituições Financeiras Operadoras (IFOs) incluem os bancos comerciais públicos e os privados. Na Figura 5, podese visualizar melhor esse desenho institucional.

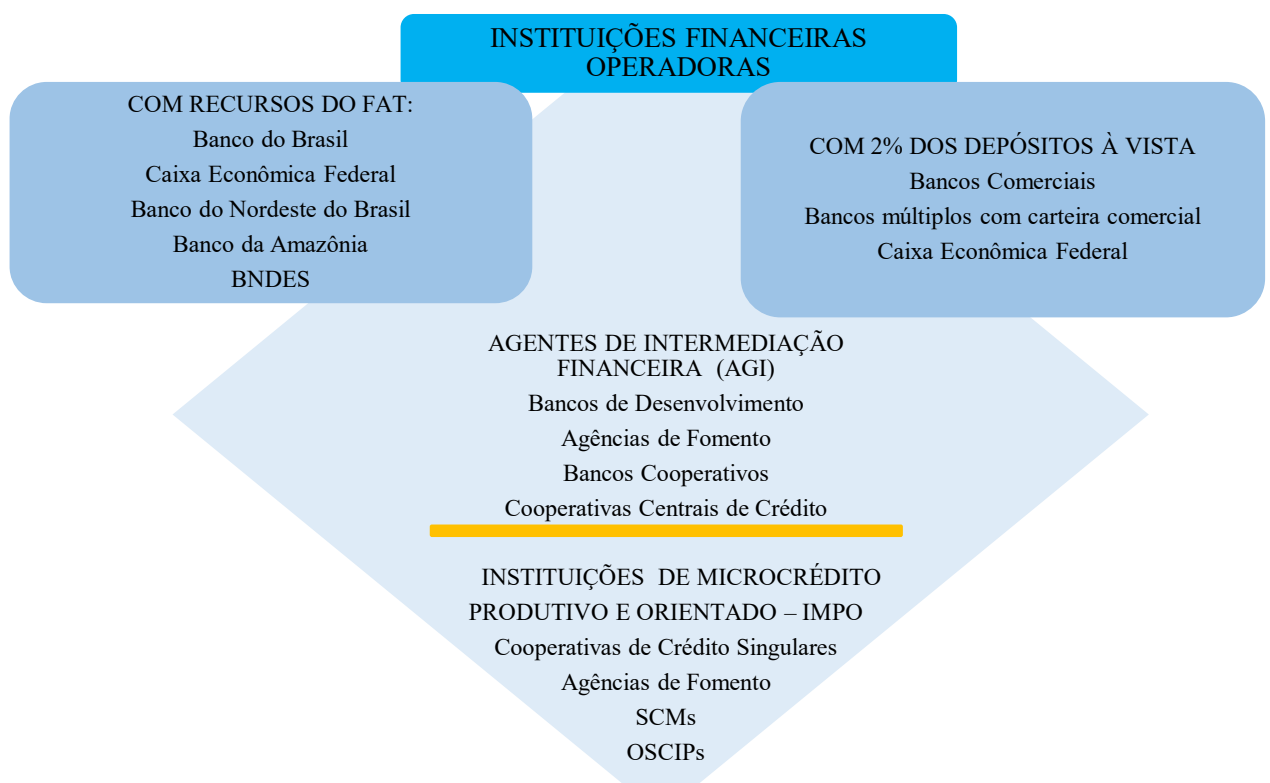

Figura 5: Desenho institucional do PNMPO.

Fonte: Elaboração própria com base na Lei 11.110/2005. 
O Conselho Monetário Nacional $(\mathrm{CMN})$ é o principal órgão regulador no âmbito do PNMPO na medida em que se estabelece a regulamentação da Lei $n^{0}$ 11.110/2005 (Brasil, 2005) no que se refere às condições para utilização de parcela dos recursos dos depósitos à vista destinados ao microcrédito.

A partir de 2005, o MTE passou a divulgar trimestralmente dados referentes à oferta de microcrédito produtivo orientado - foco do programa -, e já é possível se notar um crescimento exponencial tanto na quantidade de instituições habilitadas quanto no volume de recursos disponibilizados, conforme Tabela 1 e Figuras 6 e 7.

Tabela 1: Evolução do quantitativo de instituições habilitadas pelo MTE a operar no âmbito do PNMPO - 2005 2015

\begin{tabular}{|c|c|c|c|c|c|c|c|c|c|c|c|}
\hline IMF & 2005 & 2006 & 2007 & 2008 & 2009 & 2010 & 2011 & 2012 & 2013 & $2014^{1}$ & $2015^{2}$ \\
\hline OSCIPs & 40 & 90 & 103 & 124 & 129 & 135 & 144 & 144 & $\mathrm{NI}$ & 160 & 164 \\
\hline SCMs & 10 & 16 & 16 & 16 & 19 & 22 & 25 & 25 & NI & 25 & \\
\hline IFOs & 0 & 3 & 3 & 3 & & 5 & 8 & 8 & NI & 12 & \\
\hline Cooperativas de crédito & 0 & 100 & 120 & 125 & 127 & 147 & 168 & 168 & NI & 290 & 29 \\
\hline Agências de Fomento (AF) & 2 & 4 & 5 & 5 & 7 & 8 & 10 & 10 & NI & 10 & \\
\hline Cooperativas Centrais de Crédito & 0 & 2 & 4 & 4 & & 4 & 4 & 4 & NI & 7 & \\
\hline Bancos Cooperativos & 0 & 1 & 1 & 1 & 1 & 1 & 1 & 1 & NI & 1 & \\
\hline Bancos de desenvolvimento & & & & & & 2 & 2 & 2 & NI & 4 & \\
\hline Sociedades operadoras de MPO & & & & & & & & & NI & 2 & \\
\hline Total & 52 & 216 & 252 & 278 & 283 & 324 & 362 & 362 & NI & 511 & 52 \\
\hline
\end{tabular}

Fonte: Elaboração própria, a partir dos Relatórios PNMPO.

${ }^{1}$ Data de Referência: 09/12/2014

${ }^{2}$ Data de Referência: 08/06/2015

A Tabela 1 mostra que, em dez anos, o total de instituições habilitadas junto ao MTE, saltou de 52 para 522. 


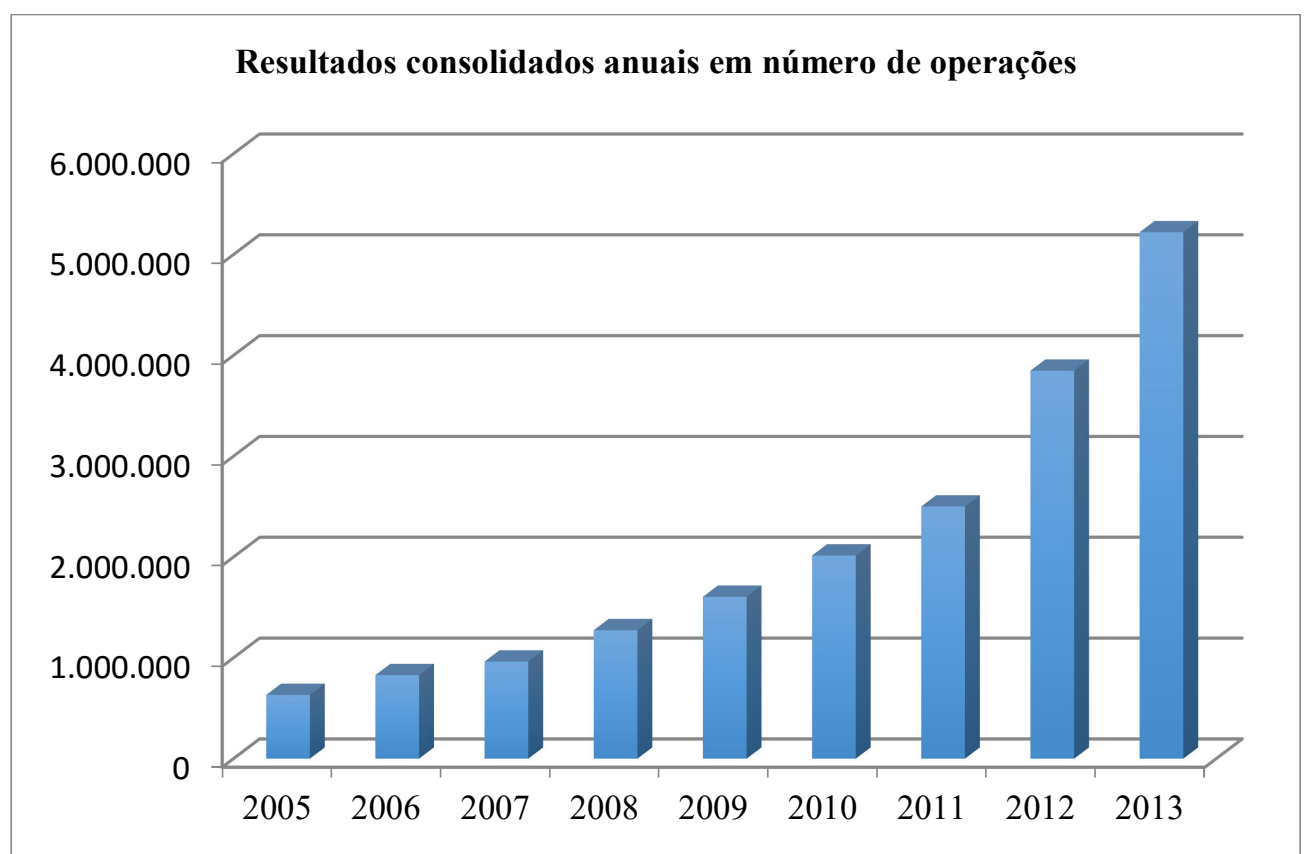

Figura 6: PNMPO - Resultados consolidados anuais em número de operações (em unidades) - 2005 - 2014 Fonte: Elaboração própria com base nos dados dos Relatórios PNMPO.

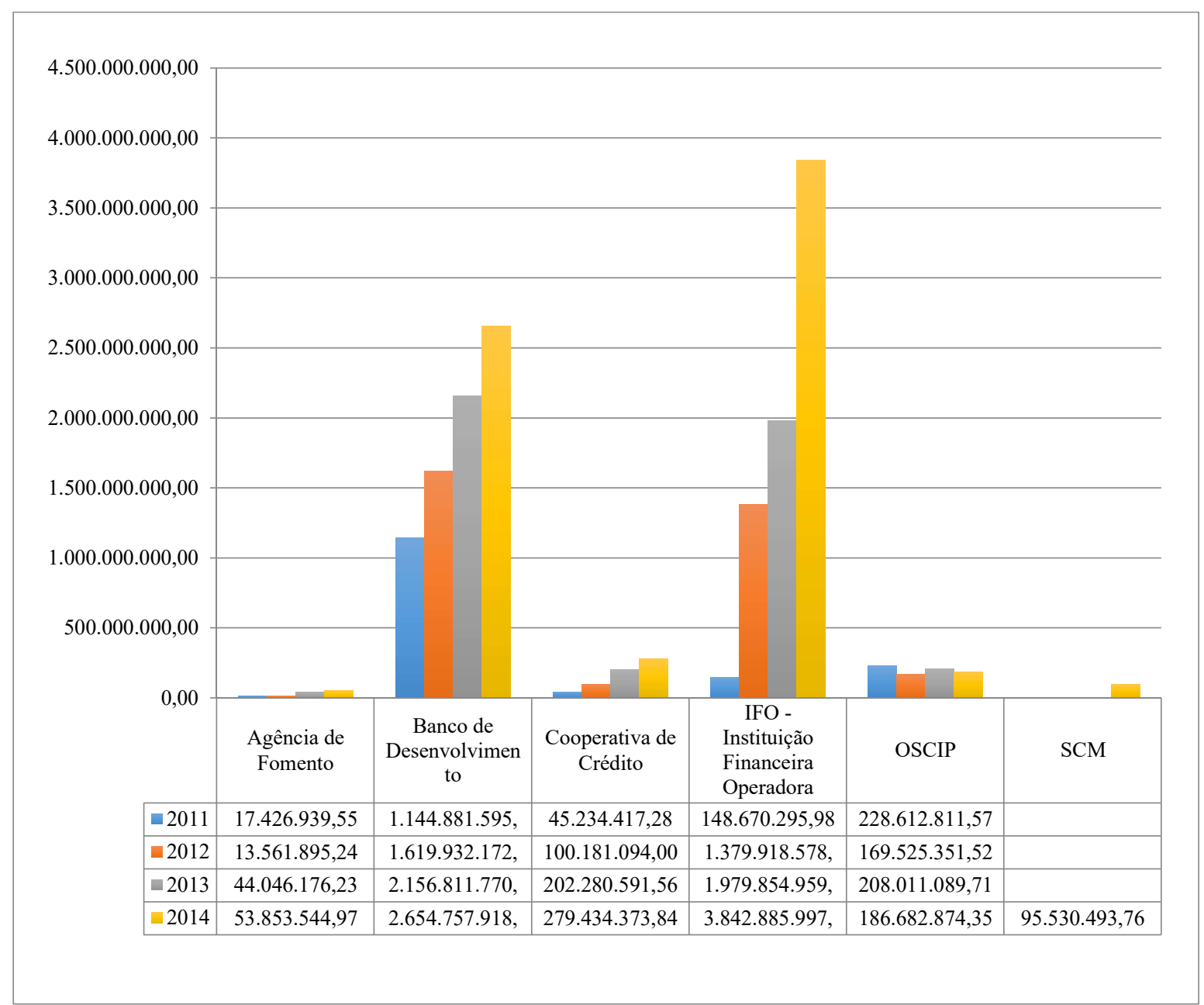

Figura 7: PNMPO - Resultados consolidados Carteira Ativa por Constituição Jurídica - Valor (R\$) a preços correntes - 2011 - 2014 Fonte: Elaboração própria com base nos dados dos Relatórios PNMPO. 
No que concerne aos estudos sobre o PNMPO, Sampaio (2014) analisou o quadro normativo do PNMPO enquanto instrumento de desenvolvimento e de superação da pobreza. Utilizando a Análise Jurídica da Política Econômica e metodologia quali-quanti, entrevistou 273 beneficiários do MPO em cinco regiões brasileiras. Os resultados mostraram que o microcrédito produtivo orientado tem efeitos limitados na superação da pobreza, sendo constatada a sua contribuição para o aumento da renda familiar - limitada empiricamente a 3 mil reais - nos segmentos de baixa renda e de extrema pobreza. $\mathrm{O}$ estudo apresentou ainda sugestões de melhorias no quadro normativo do programa. Para o autor, o PNMPO foi criado após o reconhecimento por parte do governo de que as medidas anteriores a ele de estímulo às microfinanças, a saber, a destinação dos $2 \%$ dos depósitos à vista na forma estabelecida pela Lei 10.735/03 (Brasil, 2003), não estava atendendo às demandas por microcrédito produtivo.

Silva (2012) investigou o impacto do marco legal das microfinanças no Brasil na melhoria deste segmento, em termos de sucesso das iniciativas de microfinanças. Os achados da pesquisa indicaram que: por um lado, a autorização de novos tipos de entidades e do estabelecimento de programas de microcrédito específicas teve um impacto positivo e, por outro, as regras consideradas restritas têm limitado o crescimento da maioria das instituições de microfinanciamento tendo o segmento, de acordo com a pesquisa, desenvolvido uma forte dependência do financiamento público.

Em 2011, o PNMPO passou por algumas mudanças resultando na criação do CRESCER - Programa Nacional de Microcrédito. O CRESCER, considerado uma expansão do PNMPO, foi lançado por meio da Medida Provisória $n^{0}$ 543, de 2011 (Brasil, 2011), posteriormente convertida em lei, como parte das ações de inclusão produtiva urbana da Secretaria de Política Econômica (SPE) do Ministério da Fazenda visando promover a emancipação dos beneficiários dos programas Brasil sem miséria. De acordo com a SPE (2012), o programa tem como objetivo geral elevar o padrão de vida e a geração de empregos no âmbito do programa Brasil sem miséria e especificamente: (a) dar oportunidade de novos negócios; (b) estimular o empreendedorismo e; (c) estimular a bancarização.

Para efeito do programa, o conceito de MPO foi definido como crédito para o empreendedor com renda bruta anual de até R\$ 120 mil (mesma faixa estabelecida pelo PNMPO). Os beneficiários podem ser pessoas físicas, Empreendedores Individuais (EI) ou microempresa. O valor das operações é de até R\$ 15 mil, sendo o prazo médio de 6 meses, e o direcionamento pode ser para capital de giro ou investimento. A metodologia adotada pelo Programa CRESCER é: (a) relacionamento direto com os empreendedores no local da 
atividade econômica; (b) atendimento por pessoas treinadas (agentes de crédito); (c) contato permanente para acompanhamento e orientação; (d) avaliação da atividade e da capacidade de endividamento do tomador.

Quanto às garantias, estabeleceram-se três modalidades: o aval solidário, para as operações de menor valor, e nas de maior valor e destinadas a investimentos, os bens adquiridos poderiam ser utilizados como garantia ou ainda o aval de terceiros.

Os bancos públicos federais foram fortemente recomendados a converterem a carteira de microcrédito de consumo para o MPO, com redução de juros de $60 \%$ a.a. para $8 \%$ a.a. A Taxa de Abertura de Crédito (TAC) foi reduzida de 3\% para $1 \%$.

O programa foi, inicialmente, operado por bancos públicos federais (Banco da Amazônia, BB, CEF e Banco do Nordeste) que tiveram metas a serem cumpridas em relação ao número de clientes ativos - 2,24 milhões para 2012 e 3,46 milhões para 2013 e ao total de carteira ativa - R\$ 1,73 bilhão em 2013 e R\$ 2,99 bilhões em 2013 (Secretaria de Política Econômica [SPE], 2012).

O custo total da complementação do Tesouro Nacional para a redução das taxas de juros (subvenção) estimado foi R\$ 50 milhões em 2011; R\$ 310 milhões em 2012; R\$ 483 milhões em 2013 (SPE, 2012). Além disso, o Programa previa assistência e orientação técnica no planejamento do negócio.

A subvenção poderia ser concedida pelo Tesouro Nacional a qualquer instituição financeira que operasse nas condições definidas para o programa e concordasse com os valores de equalização (compensação) definidos pelo Ministério da Fazenda (www2.planalto.gov.br). Com isso, esperava-se que o programa também fosse operado pelos bancos privados, ampliando o volume de recursos disponíveis e o número de empreendedores beneficiados. A origem dos recursos são os depósitos à vista, de acordo com a Lei 11.110/2005 (Brasil, 2005).

As condições para a concessão da subvenção ${ }^{14}$ foram definidas por meio da Portaria do Ministério da Fazenda n⿳ำ 83, de 2014 (Brasil, 2014), quais sejam: (a) taxa de juros máxima para o mutuário de até 5\% ao mês; (b) Taxa de Abertura de Crédito (TAC) de até 1,0\% sobre o valor financiado; (3) limite de 3 (três) operações com direito a subvenção a cada exercício civil por mutuário em todo o Sistema Financeiro Nacional, independentemente do prazo de cada financiamento; (4) limite de 1 (uma) operação na modalidade investimento e 1 (uma)

\footnotetext{
${ }^{14}$ Foi verificado pela pesquisa de Belloni et al., (2015, p. 121) que, em 2015, havia restrições orçamentárias para se manter a política de subvenção à atividade de microcrédito no âmbito do Programa Crescer, devido à política de ajuste fiscal adotada pelo Governo Federal. De acordo com o BCB (2015a), a subvenção do Tesouro Nacional para o Programa CRESCER foi suspensa no inicio de 2015.
} 
operação na modalidade capital de giro com direito a subvenção a cada mês, por mutuário, por instituição financeira.

A regulamentação dada pela Resolução do $\mathrm{BCB}^{\mathrm{0}} \mathrm{n}^{-3.422} / 06^{15}$ - foi a seguinte: a partir de $1^{\underline{0}}$ de janeiro de 2012 , no mínimo $10 \%$ do saldo da carteira de microcrédito deveria ser destinado ao produtivo orientado; em $1^{\circ}$ de julho de 2012, o mínimo passaria a ser de 40\%; a partir de $1^{\circ}$ de janeiro de 2013 , a exigência alcançaria $60 \%$ do saldo da carteira e, a partir de $1^{\underline{0}}$ de julho de 2013 , no mínimo $80 \%$ dos recursos de exigibilidade deveriam ser aplicados em MPO. O Ministério da Fazenda divulgou relatório em agosto de 2014 (Secretaria de Política Econômica [SPE], 2014), em que publicou os principais resultados alcançados pelo CRESCER, porém não menciona se essas metas foram ou não cumpridas.

Ainda de acordo com a referida Resolução - 4.000/2011 (BCB, 2011) -, as operações de microcrédito podem ser realizadas com empreendedores urbanos e rurais, pessoa física ou jurídica e independem da fonte de recursos. O que define a operação como MPO é a metodologia adotada na concessão do crédito. A mesma Resolução do BCB também fixou que o tomador de microcrédito pode ter mais de uma operação de financiamento no sistema bancário desde que, somadas, não ultrapassem R $\$ 20$ mil. O programa CRESCER limitou em R\$ 15 mil por operação.

O programa CRESCER foi regulamentado pela Resolução do BCB nº 4.000/2011 (BCB, 2011). Em seu Art. 3º a Resolução determina que as taxas de juros efetivas não podem exceder: (a) 2\% a.m. (dois por cento ao mês); ou b) 4\% a.m. (quatro por cento ao mês) nas operações de microcrédito produtivo orientado concedidas em conformidade com o Art. $4^{\circ}$. Determina ainda a mesma Resolução que o valor da Taxa de Abertura de Crédito (TAC) não ultrapasse 3\% (três por cento). No âmbito do Programa CRESCER e para fazer jus ao subsídio essas taxas, inicialmente, foram estabelecidas em $8 \%$ a.a., no máximo, para os juros e $3 \%$ (máxima) para a $\mathrm{TAC}^{16}$.

Ainda conforme a Resolução $n^{0}$ 4.000/2011, as instituições acima referidas necessitam habilitar-se no MTE, por meio de cadastro, termo de compromisso e plano de trabalho, discriminando a metodologia de microcrédito produtivo orientado a ser utilizada, a forma de acompanhamento dos financiamentos, com os respectivos instrumentos a serem utilizados, e

\footnotetext{
${ }^{15}$ Esta Resolução foi revogada pelo artigo 12 da Resolução no 4.000/2011 (BCB, 2011).

${ }^{16}$ Esses valores foram atualizados conforme Portaria $\mathrm{n}^{\mathrm{o}}$ 83, de 21 de março de 2014 (Brasil, 2014), do Ministério da Fazenda, a qual estabelece as condições para pagamento de equalização do Programa CRESCER no âmbito do PNMPO para o exercício de 2014 e autoriza o pagamento de equalização de parte dos custos a que estão sujeitas as instituições financeiras para contratação e acompanhamento de operações de microcrédito produtivo orientado contratadas a partir de $1^{\circ}$ de janeiro de 2014 , desde que observadas as seguintes condições: (a) taxa de juros para o mutuário: até $5 \%$ a.a (cinco por cento ao ano); (b) taxa de abertura de crédito (TAC): até 1,0\% (um por cento) sobre o valor financiado.
} 
os índices de desempenho (BCB, 2011). Os agentes de intermediação entre as instituições financeiras e as instituições de microcrédito produtivo orientado, quais sejam: bancos de desenvolvimento, agências de fomento, bancos cooperativos e cooperativas centrais de crédito, também precisam habilitar-se no MTE.

A Resolução do BCB n⿳ 4.153, de 30 de outubro de 2012 (BCB, 2012a), acrescenta que a verificação do não atendimento das condições para caracterização de operação como microcrédito produtivo orientado implicará a desclassificação da IMC para fins do cumprimento da exigibilidade de que trata esta Resolução, e devem ser retificadas de imediato as informações remetidas ao $\mathrm{BCB}$ a esse respeito.

As principais características dos programas PNMPO e CRESCER estão resumidas na Figura 8:

\begin{tabular}{|c|c|c|}
\hline Características & Até 2011 & Após 2011 \\
\hline Nome do Programa & $\begin{array}{l}\text { PNMPO (Programa Nacional de } \\
\text { Microcrédito Produtivo Orientado) }\end{array}$ & $\begin{array}{l}\text { CRESCER - Programa Nacional } \\
\text { de Microcrédito. }\end{array}$ \\
\hline Fontes dos recursos & $\begin{array}{l}\text { FAT (Fundo de Amparo ao Trabalhador) e } \\
2 \% \text { dos depósitos à vista dos bancos }\end{array}$ & $\begin{array}{l}\text { Tesouro Nacional (até R\$ } 500 \\
\text { milhões por ano para custear a } \\
\text { redução dos juros, e a orientação } \\
\text { para o crédito produtivo) e } 2 \% \text { dos } \\
\text { depósitos à vista dos bancos. }\end{array}$ \\
\hline $\begin{array}{l}\text { Instituições Financeiras } \\
\text { Operadoras (IFOs) }\end{array}$ & $\begin{array}{l}\text { O Com os recursos do FAT: Banco do } \\
\text { Brasil, Caixa Econômica Federal, Banco } \\
\text { do Nordeste, Banco da Amazônia, Banco } \\
\text { Nacional de Desenvolvimento } \\
\text { Econômico e Social (BNDES) - } \\
\text { instituições financeiras oficiais de que } \\
\text { trata a Lei n } \mathrm{n}^{\mathrm{o}} \text { 8.019, de } 11 \text { de abril de } \\
1990 \text { (Brasil, 1990a); } \\
\text { Com a parcela dos recursos de depósitos } \\
\text { à vista: os bancos comerciais, os bancos } \\
\text { múltiplos com carteira comercial e a } \\
\text { Caixa Econômica Federal. }\end{array}$ & $\begin{array}{l}\text { Bancos Públicos Federais } \\
\text { (Banco do Brasil, Caixa } \\
\text { Econômica Federal, Banco do } \\
\text { Nordeste e Banco da Amazônia, } \\
\text { demais bancos comerciais e } \\
\text { bancos múltiplos com carteira } \\
\text { comercial. }\end{array}$ \\
\hline $\begin{array}{l}\text { As Instituições de } \\
\text { Microcrédito Produtivo } \\
\text { Orientado (IMPOs) }\end{array}$ & $\begin{array}{l}\text { Cooperativas de crédito singulares, } \\
\text { Agências de fomento, SCMs e OSCIPs que } \\
\text { desenvolvam atividades de crédito } \\
\text { destinadas a microempreendedores. }\end{array}$ & Sem alteração. \\
\hline $\begin{array}{l}\text { Agentes de Intermediação } \\
\text { (AGIs) - repassadores de } \\
\text { recursos das IFOs para as } \\
\text { IMPOs }\end{array}$ & $\begin{array}{l}\text { Bancos de desenvolvimento, Agências de } \\
\text { fomento, Bancos cooperativos e } \\
\text { Cooperativas Centrais de Crédito. }\end{array}$ & Sem alteração. \\
\hline Taxa de Juros & $60 \%$ a.a. & $8 \%$ a.a. \\
\hline $\begin{array}{l}\text { Taxa de Abertura de Crédito } \\
\text { (TAC) }\end{array}$ & $3 \% \mathrm{~s} . /$ valor do financiamento & $1 \% \mathrm{~s} . /$ valor do financiamento. \\
\hline $\begin{array}{l}\text { Subvenção governamental } \\
\text { para bancos múltiplos com } \\
\text { carteira comercial, caixa } \\
\text { Econômica Federal, bancos } \\
\text { de desenvolvimento e } \\
\text { agências de fomento. }\end{array}$ & & $\begin{array}{l}\text { Concessão de Subvenção } \\
\text { econômica - até R\$ } 500 \text { milhões } \\
\text { por ano pagos pelo Tesouro } \\
\text { Nacional para garantir a redução } \\
\text { dos juros e a orientação para o } \\
\text { crédito. }\end{array}$ \\
\hline
\end{tabular}




\begin{tabular}{|c|c|c|}
\hline Características & Até 2011 & Após 2011 \\
\hline Público-alvo & $\begin{array}{l}\text { Empreendedores informais (Pessoas } \\
\text { Físicas), Empreendedores Individuais (EI) e } \\
\text { microempresas com faturamento de até R\$ } \\
120 \text { mil anuais. }\end{array}$ & Sem alteração. \\
\hline Metas & & $\begin{array}{l}\text { Até } 2013 \text {, beneficiar cerca de } 3,4 \\
\text { milhões de clientes e a carteira } \\
\text { ativa deveria alcançar R } \$ 3 \text { bilhões, } \\
\text { divididos entre Banco da } \\
\text { Amazônia, BB, CEF e Banco do } \\
\text { Nordeste. }\end{array}$ \\
\hline Metodologia & $\begin{array}{l}\text { Aval solidário, acompanhamento de um } \\
\text { agente de crédito, progressividade dos } \\
\text { empréstimos, periodicidade dos pagamentos } \\
\text { e capacitação para o crédito. }\end{array}$ & Sem alteração. \\
\hline $\begin{array}{l}\text { Normas s./direcionamento } \\
\text { obrigatório de } 2 \% \text { dos } \\
\text { depósitos à vista dos bancos } \\
\text { comerciais, bancos múltiplos } \\
\text { com carteira comercial e } \\
\text { Caixa Econômica Federal. }\end{array}$ & & $\begin{array}{l}\text { Pelo menos } 80 \% \text { dos } 2 \% \text { devem ser } \\
\text { direcionados para o microcrédito } \\
\text { produtivo e orientado devendo ser } \\
\text { introduzidos de forma progressiva: } \\
10 \% \text { a partir de janeiro de } 2012 ; \\
40 \% \text { a partir de julho, } 60 \% \text { a partir } \\
\text { de janeiro de } 2013 \text {, atingindo os } \\
80 \% \text { em julho de } 2013 \text {. }\end{array}$ \\
\hline
\end{tabular}

Figura 8: Quadro Características do PNMPO/CRESCER.

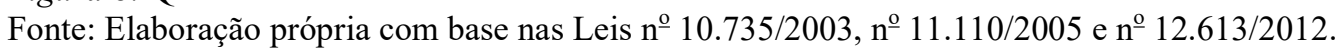

De acordo com relatório divulgado pelo Ministério da Fazenda (Secretaria de Política Econômica [SPE], 2013a), o programa possuía em maio de 2013, 2.564 .909 clientes ativos e $\mathrm{R} \$ 2.529 .443$ mil em carteira ativa. Quanto ao desempenho do programa, de setembro de 2011 a maio de 2013, de acordo com o referido relatório, o CRESCER realizou 5.449.363 operações, com valor total contratado de $\mathrm{R} \$ 6.962 .671$ mil e valor médio contratado de $\mathrm{R} \$$ 1.278 (SPE, 2013a).

Em agosto de 2014, após exatos três anos de implementação das referidas mudanças no PNMPO, a SPE do Ministério da Fazenda divulgou relatório com os principais resultados alcançados. Os dados estão resumidos nas Figuras 9 e 10. 


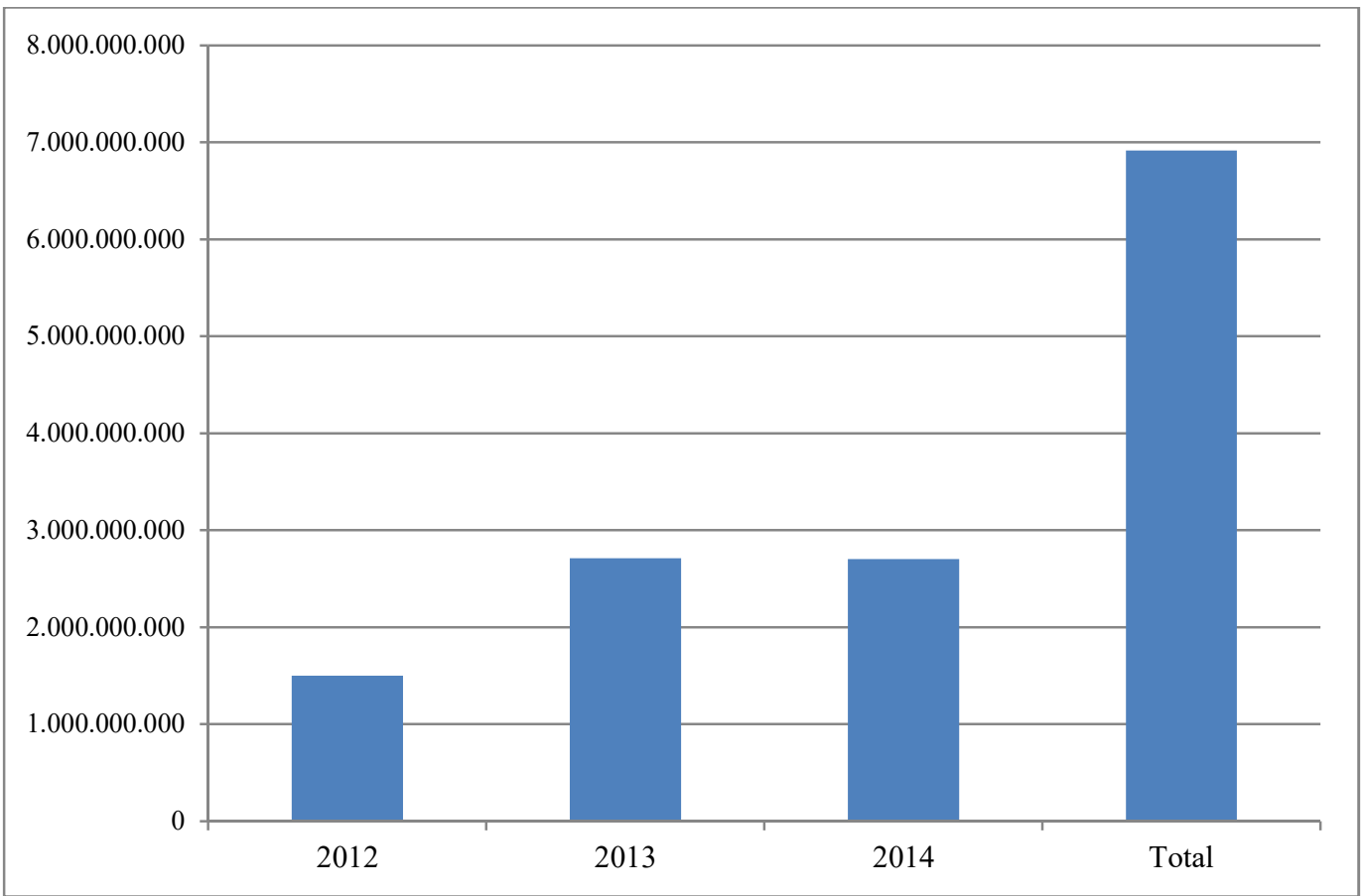

Figura 9: Programa CRESCER - Valor contratado por ano* (R\$) a preços correntes - 2012 - 2014 Fonte: Elaboração própria com base em dados da SPE (2014).

Nota: * Contratações até o mês de junho de cada ano.

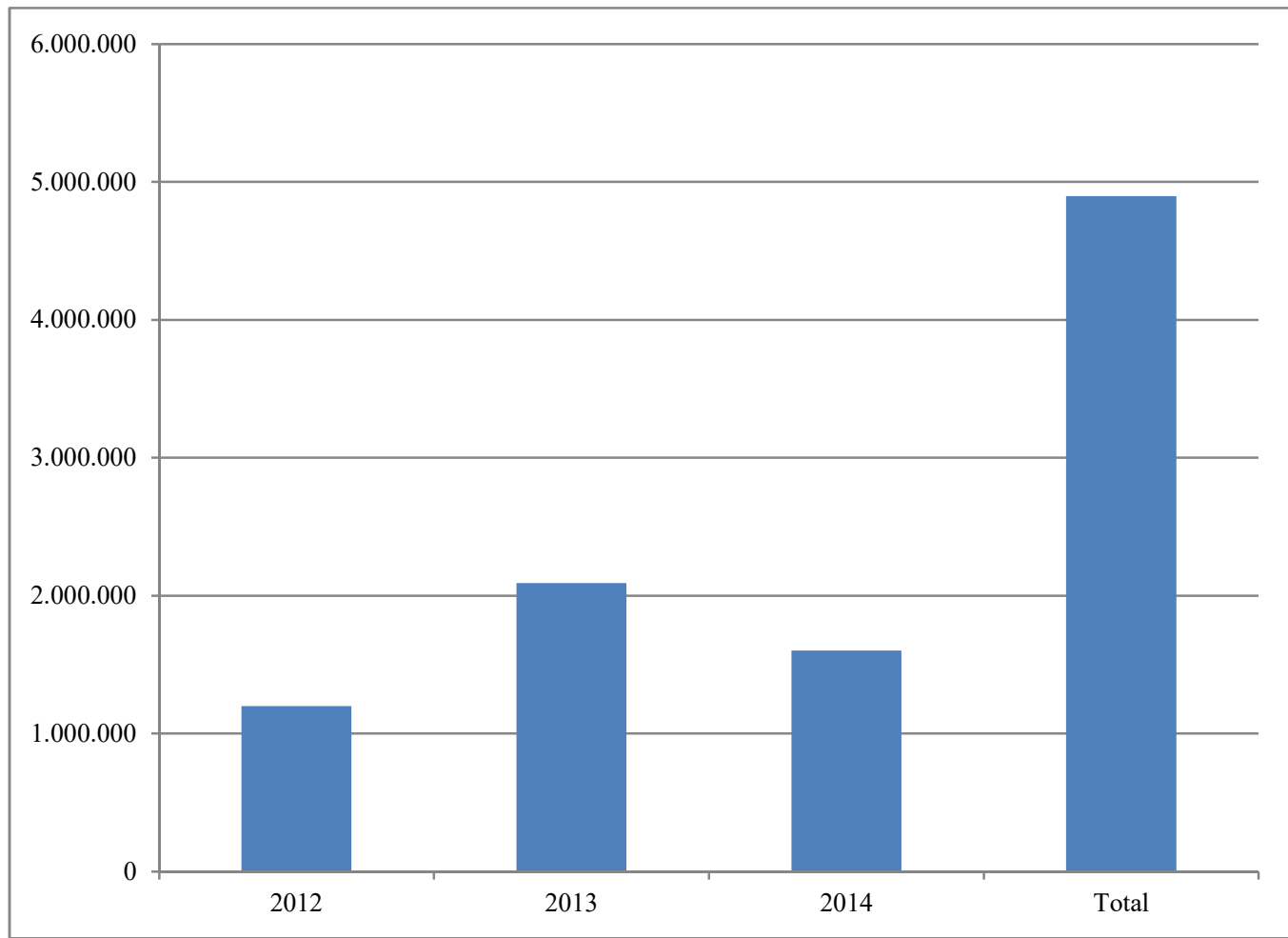

Figura 10: Programa CRESCER - Número de operações por ano* (R\$) a preços correntes - 2012 - 2014 Fonte: Elaboração própria com base em dados da SPE (2014).

Nota: * Contratações até o mês de junho de cada ano.

O principal reflexo das mudanças que já aparecem no relatório é o crescimento da oferta de crédito pelos bancos públicos, especialmente a CEF. 
No $4^{\underline{0}}$ trimestre de 2014, o Banco do Nordeste do Brasil, a Caixa Econômica Federal, o Banco do Brasil e o Banco da Amazônia responderam por R\$ 2,860 bilhões ofertados no PNMPO, o que equivale a $90,57 \%$ do volume total de microcrédito concedido no período. Ao longo de 2014, os bancos públicos federais ofertaram R \$ 10,523 bilhões em microcrédito produtivo orientado, o que responde por $90,35 \%$ do montante total de microcrédito ofertado. Os valores de 2014 representam uma expansão de $16 \%$ em relação ao observado para 2013. (Relatório Gerencial do Programa Nacional de Microcrédito Produtivo Orientado do $4^{\underline{0}}$ trimestre de 2014, p. 11).

No último trimestre de 2013, a Caixa Econômica ofertou R\$ 1 bilhão em microcrédito produtivo orientado, o que colocou o Banco como o segundo maior ofertante de microcrédito no âmbito do PNMPO, ficando atrás apenas do Banco do Nordeste (conforme Figuras 11, 12 e 13).

"Esse salto quantitativo da Caixa dentro do PNMPO deve-se à ampliação das operações da CAIXA CRESCER, subsidiária vinculada ao Banco, que é responsável pela captação, orientação e acompanhamento dos clientes de microcrédito produtivo" (Relatório Gerencial do Programa Nacional de Microcrédito Produtivo Orientado do $4^{\underline{0}}$ trimestre de 2013, p. 9).

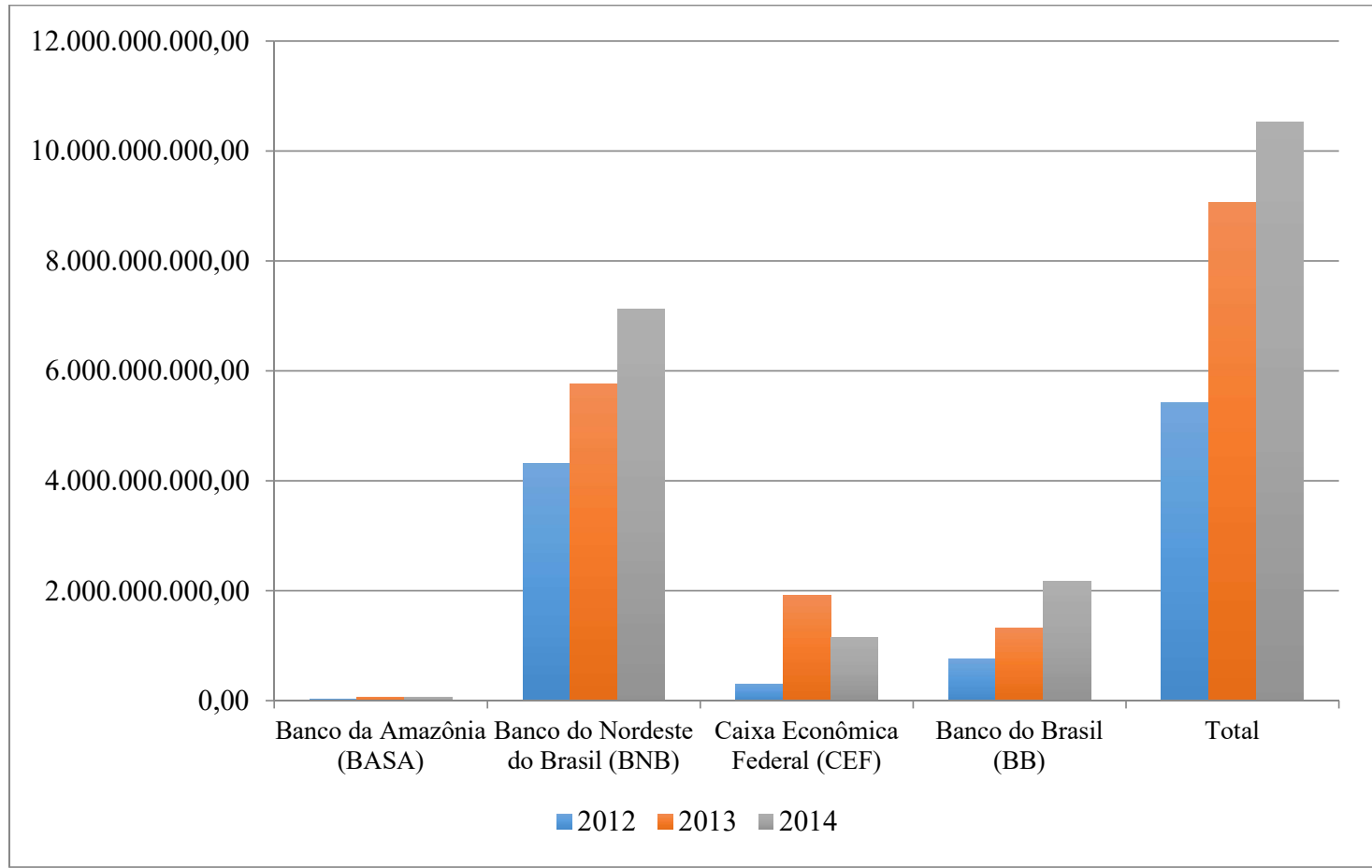

Figura 11: PNMPO - Execução pelos Bancos Públicos Federais - Recursos emprestados (em R\$ a preços correntes) - $2012-2014$.

Fonte: Elaboração própria com base em Relatórios do MTE. 


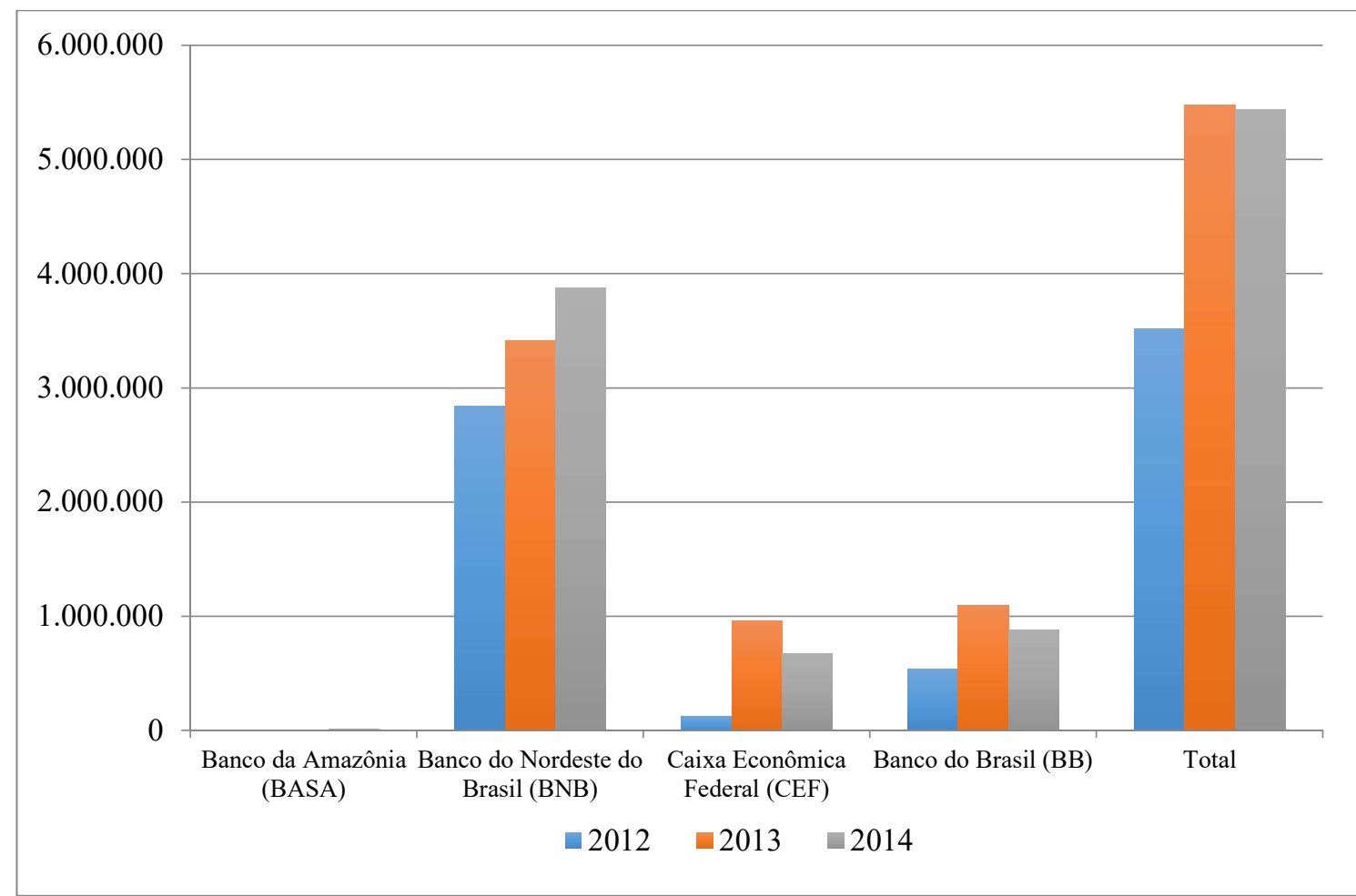

Figura 12: PNMPO - Execução pelos Bancos Públicos Federais - Número de contratos realizados - 2012 2014.

Fonte: Elaboração própria com base em Relatórios do MTE.

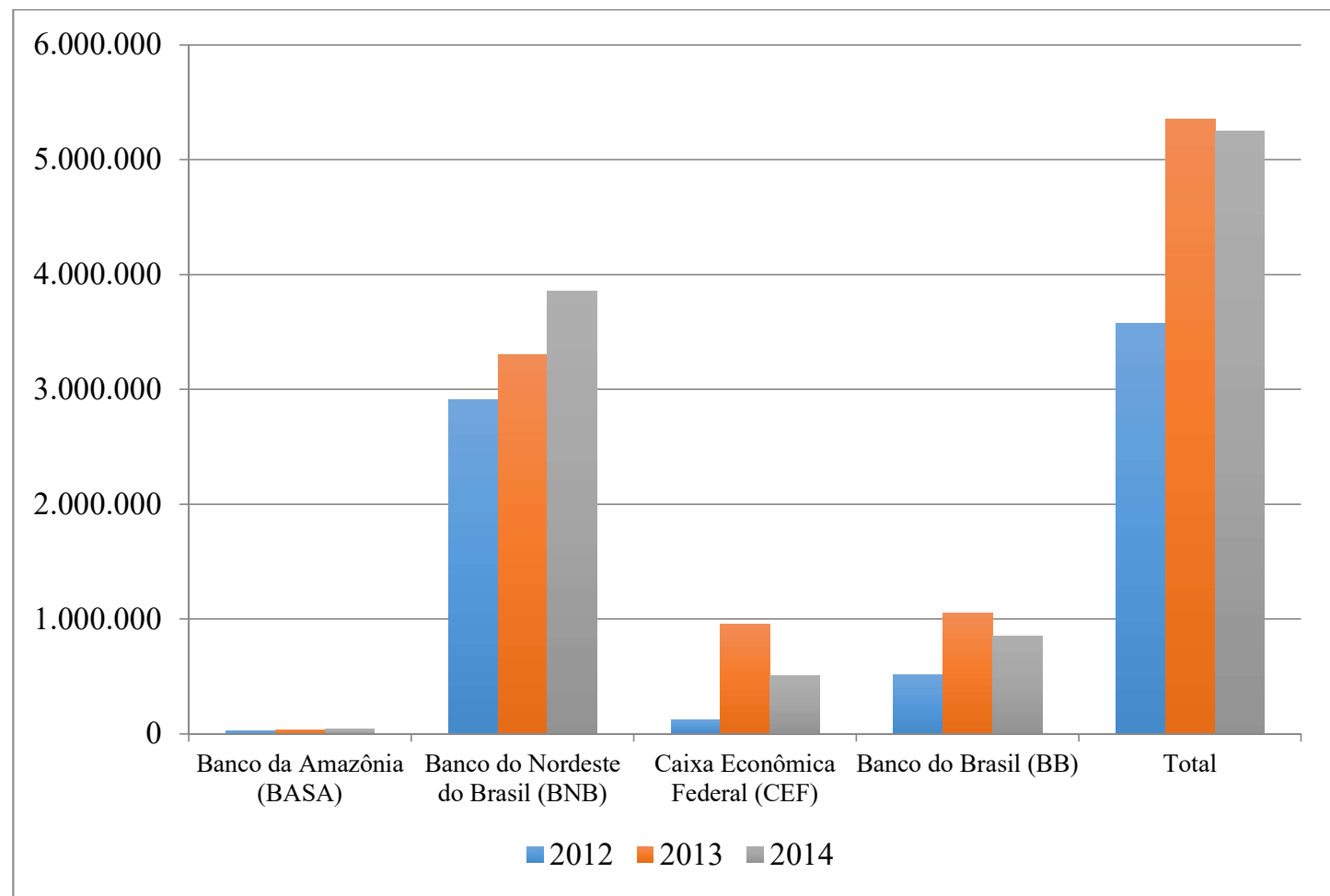

Figura 13: PNMPO - Execução pelos Bancos Públicos Federais - Número de clientes atendidos - 2012 - 2014. Fonte: Elaboração própria com base em Relatórios do MTE.

As informações tabuladas sugerem, num primeiro momento, que as demais instituições, a exemplo das OSCIPs, sofreram impacto negativo das mudanças no PNMPO 
(redução do volume de recursos emprestados, do número de contratos e do número de clientes atendidos), como observado na Figura 14.

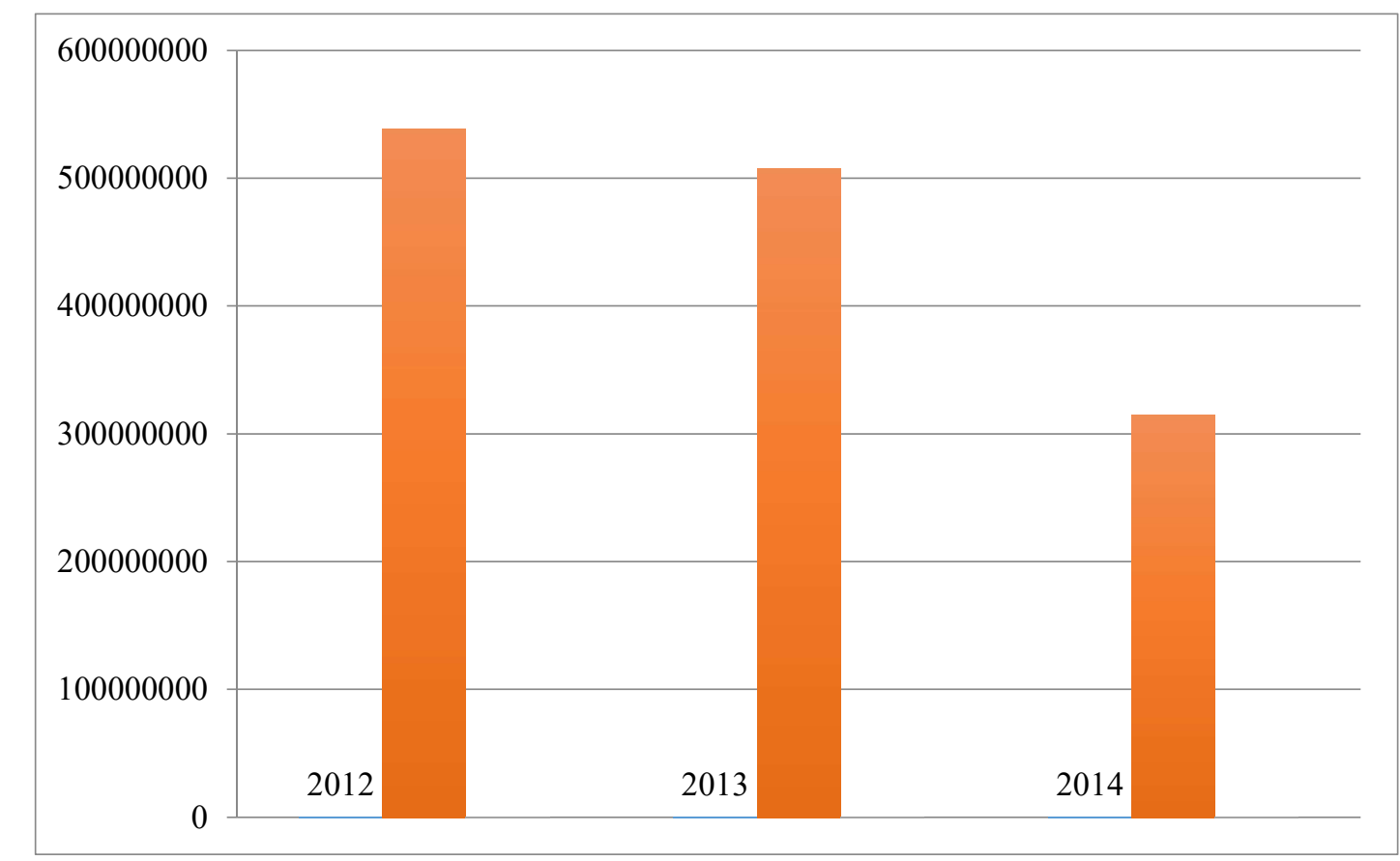

Figura 14: PNMPO - Execução pelas OSCIPs - Recursos emprestados (em R\$ a preços correntes) - 2012 2014.

Elaboração própria com base em Relatórios do MTE.

Uma outra questão que pode ser discutida com base na observação dos dados é se o aumento da atuação do Estado - principalmente por meio da criação dos subsídios que afetam mais diretamente os bancos públicos - não provoca um efeito negativo nas demais IMFs que não são diretamente afetadas, tendo em vista que prejudicaria o livre funcionamento do mercado, fato que vai de encontro ao que sugerem tanto a literatura internacional quanto os organismos internacionais, como boas práticas de regulação de microfinanças. Janda e Zetek (2014), por exemplo, afirmam que taxas de juros em microfinanças geralmente são subsidiadas por recursos públicos e podem trazer desvantagens para as IMFs que não as recebem.

No que toca à questão da concorrência, por exemplo, Kai (2009) investigou a relação empírica entre a concorrência e a amplitude do alcance (mensurada por meio do número de empréstimos aos mutuários pobres), além do impacto da concorrência na autossuficiência financeira. Para tanto, utilizou uma base de dados financeiros para 450 IMFs socialmente orientadas em 71 países, entre 2003 e 2006. O estudo concluiu que: (1) a concorrência não tem um impacto significativo na autossuficiência financeira; (2) a concorrência reduz a amplitude do alcance - os mutuários mais pobres são retirados da carteira de crédito de microfinanças ; e (3) este impacto negativo da concorrência na amplitude do alcance diminui 
com o aumento da experiência da IMF. Enfim, para aquela amostra, a concorrência não piorou a autossuficiência financeira e, portanto, o autor afirma que a concorrência não aumenta a dependência de subsídios, diferente de análises teóricas referenciadas pelo autor, as quais afirmavam que a concorrência tem um impacto negativo sobre o desempenho financeiro de IMFs socialmente motivadas. O autor ressalta que é preciso considerar os efeitos adversos da concorrência, a fim de se evitar que os tomadores mais pobres sejam excluídos do mercado. Ele defende que os governos e os doadores devem aumentar os subsídios apenas para as IMFs socialmente orientadas (visando aos mutuários mais pobres). Outros autores, como Armendáriz \& Morduch (2010) criticam o crédito associado a subsídios e a taxas de juros baixas, pois na opinião deles, esse tipo de medida oferece desincentivo para pagamentos regulares.

Assim, a despeito de alguns autores (Aghion \& Morduch, 2005; Janda \& Zetek, 2014; Robinson, 2001) considerarem os subsídios prejudicial às IMFs, uma vez que as tornam dependentes destes recursos; outros, como Conning (1999), os considera importantes e necessários sempre para que as IMFs alcancem os mais pobres. Há ainda aqueles que defendem o uso de subsídios somente nos estágios iniciais da atividade das IMFs (antes dos retornos das economias de escala), os chamados subsídios inteligentes (Morduch, 1999).

O uso de subsídios, para Conning (1999), pode aumentar o alcance do microcrédito tanto em amplitude como em profundidade, considerando que os subsídios resolveriam o problema do elevado custo fixo de se fazer pequenos empréstimos, embora o autor também admita a possibilidade de se cobrar taxas de juros mais elevadas em operações de microcrédito em função do alto custo de monitoramento. $\mathrm{O}$ autor acrescenta que o crédito subsidiado só vale a pena se os seus benefícios sociais excederem os seus custos sociais. $\mathrm{Na}$ prática, porém, a mensuração dos benefícios sociais é muito complexa e onerosa e, portanto, uma análise de custo-benefício social é difícil de ser realizada pelos formuladores de políticas. Haveria, então, um trade-off nos subsídios: de um lado, configura-se como um benefício, pois pode ampliar o alcance do microcrédito (desempenho social) mas, por outro lado, pode contribuir para uma ineficiência das instituições que não buscariam melhorar sua eficiência em relação à gestão de custos e consequente retorno da operação. Ainda conforme este autor, a eliminação de subsídios ao microcrédito pode forçar os programas a excluírem tomadores mais pobres de seus portfólios, dado que eles são os mais difíceis de serem atendidos e oneram muito a instituição.

Existem vários tipos de subsídios. Em instituições financeiras os mais comuns são taxas de juros abaixo do mercado sobre os fundos emprestados, depósito compulsório, 
reembolso direto de alguns (ou todos) os custos incorridos na instituição financeira, transferências financeiras diretas e isenção de impostos (Schreiner \& Yaron, 1999). Os subsídios também funcionam para evitar o racionamento do crédito explicado por Stiglitz e Weiss (1981) na medida em que aumentam a oferta de empréstimos para os que mais necessitam. Teriam também o papel de selecionar os bons pagadores, uma vez que as taxas de juros mais baixas os atrairiam (seleção adversa e risco moral) (Townsend e Yaron, 2001).

O presente estudo aborda o uso dos subsídios na perspectiva de manutenção de baixas taxas de juros para os mutuários pobres (Aghion \& Morduch, 2005), ao considerar que os subsídios criados pelo programa CRESCER referem-se exclusivamente a um custeamento pelo Tesouro Nacional das taxas de juros.

Outra discussão em torno do uso de subsídios em programas de microcrédito é a sua relação com a inadimplência. Robinson (2001) afirma que há evidências substanciais de que programas de crédito subsidiados em países em desenvolvimento resultam em alta inadimplência e geram perdas para as instituições financeiras que os administram. Assegura ainda a autora que IMFs que recebem funding subsidiados são menos propensas a gerir eficazmente o seu desempenho financeiro, pois teriam pouco ou nenhum incentivo para se tornarem sustentáveis.

Dentre as críticas apresentadas aos programas de microcrédito subsidiados, há uma crença de que taxas de juros muito abaixo das de mercado levam os tomadores a confundirem empréstimos com doações, não se sentindo obrigados a honrarem o compromisso, o que levaria a uma maior inadimplência.

Ainda no que toca à inadimplência, Stiglitz e Weiss (1981) afirmam que taxas de juros muito elevadas apresentam um maior risco de inadimplência atraindo os maus pagadores e eliminando os bons. Sendo assim, a expectativa deste estudo é que com menores taxas de juros proporcionadas pelo programa CRESCER, a inadimplência seja menor, uma vez que atrai os tomadores com menor grau de risco (seleção adversa).

Outro fator que contribui para uma menor inadimplência nas operações de microcrédito é que a tecnologia de acompanhamento do crédito permite que as instituições monitorem as ações dos tomadores após a contratação diminuindo o risco de não pagamento (risco moral), o que não ocorre nas demais modalidades de crédito.

Com efeito, as mudanças regulatórias no microcrédito analisadas pelo presente estudo, principalmente a redução das taxas de juros e a criação de subsídios, trouxeram reflexos diretos e indiretos para as instituições concedentes desta modalidade de crédito. Os efeitos 
dessas mudanças no desempenho (financeiro e social) das IMFs, especificamente, nas cooperativas de crédito, é o que a presente pesquisa investiga.

Espera-se, portanto, uma relação significante estatisticamente e negativa entre as variáveis proxies do desempenho financeiro e mudanças regulatórias no microcrédito, uma vez que o subsídio criado não é suficiente para compensar o aumento dos custos decorrentes da redução das taxas de juros cobradas na operação. Como visto, as operações de MPO são caras em virtude da tecnologia de acompanhamento do crédito que lhe é característica. Se ocorrer, como esperado, uma substituição do microcrédito produtivo pelo de consumo, os custos da operação tendem a crescer.

De outro modo, como os subsídios aumentam o alcance, espera-se que as variáveis proxies do desempenho social sejam positivamente impactadas.

\subsection{Desempenho de instituições financeiras}

O desempenho de instituições, com base na abordagem da Contabilidade Financeira, em geral faz uso de indicadores contábeis como instrumental de análise. O uso de indicadores ou índices contábeis como técnica de avaliação de desempenho tem sido amplamente feito, uma vez que esses indicadores são ferramentas importantes para evidenciar a situação econômica e financeira de qualquer organização, além de serem úteis, também, na tomada de decisões. Matarazzo (2008) define indicador contábil como a relação entre contas ou grupo de contas das demonstrações financeiras e subdivide a análise das demonstrações financeiras em índices que evidenciam a situação financeira, por exemplo os que mensuram a estrutura patrimonial, a liquidez e a rentabilidade ou lucratividade.

A análise das demonstrações financeiras é classificada por Martins, Miranda, e Diniz (2014, p. 189) em análise financeira e análise econômica. A análise financeira é realizada por meio dos índices de liquidez, estrutura patrimonial e prazos médios. $\mathrm{O}$ aspecto econômico é analisado por meio dos indicadores de rentabilidade. Para os autores, a rentabilidade é "a alma do negócio", uma vez que sua ausência compromete a continuidade da empresa. Nessa perspectiva, esta pesquisa delimita a análise de desempenho à dimensão econômica, ou seja, à análise de rentabilidade.

Os índices de rentabilidade clássicos propostos por Assaf Neto (2010), Iudícibus (2009), Martins, Diniz e Miranda (2012) e Matarazzo (2008) são quatro: giro do ativo, margem líquida, Retorno sobre o Ativo (Return on Assets - ROA) e Retorno sobre o Patrimônio (Return on Equity - ROE). O giro do ativo, segundo Martins et al. (2012), na 
verdade é um indicador de giro e não de rentabilidade; margem líquida, de acordo com os mesmos autores, é mais utilizado por empresas não financeiras, pois indica o quanto a empresa obtém de lucro para cada unidade monetária vendida. Sendo assim, esta pesquisa considera somente $R O A$ e $R O E$, dado o caráter das instituições analisadas.

$\mathrm{O} R O A$ é a razão entre o resultado total e o ativo total, e indica o quanto a instituição usou bem ou mal o seu ativo total para gerar retorno econômico. Já o $R O E$ mensura a variação (crescimento ou redução) do capital próprio de uma organização em decorrência das atividades econômicas por ela realizadas. Em outras palavras, é a razão entre o resultado total e o patrimônio líquido. Mais precisamente, o $R O E$ mede a capacidade de geração de receita. De acordo com Assaf Neto (2010), o ROE mede o quanto os acionistas auferem de lucro para cada unidade monetária de recursos próprios investido na empresa. No caso das cooperativas, os recursos próprios investidos são o capital social integralizado pelos sócios ou cooperados.

Todavia, existem críticas ao uso destes indicadores como as de Martins et al. (2012, p. 224), que consideram que o $R O A$, conceitualmente, expressa uma informação muito pobre, porque "mistura dois conceitos importantes que devem ser tratados à parte" - lucro operacional e lucro líquido (que contêm o efeito das despesas financeiras). No entanto, os autores admitem que "para certas análises evolutivas" este índice pode até ajudar. A despeito da ressalva, os mesmos autores julgam o $R O A$ como o mais importante indicador de rentabilidade, porque retrata a capacidade da instituição de remunerar o capital investido pelos proprietários (sócios, acionistas e cooperados).

No caso específico de instituições financeiras, as demonstrações contábeis são regulamentadas principalmente pela $\mathrm{CVM}$ e pelo $\mathrm{BCB}$, principal regulador. Os relatórios financeiros são elaborados por meio do Plano Contábil das Instituições Financeiras do Sistema Financeiro Nacional (COSIF) e possuem algumas peculiaridades características deste tipo de instituição.

A Contabilidade Bancária tem como objetivo produzir demonstrativos que evidenciem a situação econômica e financeira, tanto de forma estática quanto dinâmica, relativas a instituições financeiras e de crédito. Os riscos inerentes ao sistema financeiro estão entre as variáveis mais importantes nas análises da contabilidade financeira e contabilidade bancária. Embora, em alguns casos estes dois ramos da contabilidade sejam tomados como sinônimos, existem algumas pequenas diferenciações entre elas. As principais características da Contabilidade Bancária são: (a) os dados deste setor são mais restritos em razão do sigilo bancário e, sendo assim, necessitam de indicadores específicos; (b) há uma interdependência entres as Ifs, sobretudo quanto aos empréstimos interbancários; (c) as IFs estão expostas a 
todos os tipos de riscos inerentes ao sistema financeiro. De acordo com Beneditto e Silva (2008), a atividade bancária, por sua natureza, expõe as IFs aos riscos de crédito, de país, de transferência, de mercado, de liquidez, operacional, legal e de reputação.

Comparando-se instituições financeiras e não financeiras, Bushman (2014) afirma que os balanços das IFs possuem menor índice de transparência em decorrência de os ativos refletirem decisões de investimento com base em informações privadas sobre os mutuários e projetos que não são disponibilizados para os usuários externos. Acrescenta o autor que o papel de alocação eficiente de capital escasso para a economia é inerente às instituições financeiras bancárias. Ademais, estas IFs possuem papel central no sistema financeiro por criar moeda e por impor externalidades em toda a economia.

Isto posto, os relatórios financeiros de IFs possuem algumas peculiaridades, como: os ativos dos bancos são ativos financeiros e se diferenciam dos ativos convencionais por não possuírem estoques nem ativo imobilizado. Assim, alguns índices de desempenho gerais não são aplicáveis às IFs como giro do ativo e margem líquida.

\subsection{Desempenho de Instituições Microfinanceiras (IMFs)}

A análise de desempenho de uma IMF, em alguns aspectos, segue os mesmos critérios das instituições financeiras convencionais, conquanto algumas especificidades inerentes a este tipo de instituição têm suscitado debates e estudos empíricos a respeito. A principal característica das IMFs é o que uma parte da literatura analisada denominou double bottom line. Double bottom line ou duplo objetivo, ou ainda duplo desafio, é considerado a principal missão das IMFs. Originalmente, elas surgiram com o intuito de alcançar os mais pobres e desassistidos, excluídos do sistema financeiro tradicional. Ao mesmo tempo, para que essa meta seja alcançada, as IMFs precisam, minimamente, garantir algum resultado econômico e financeiro positivo, o que significa ser econômico e financeiramente sustentável. Assim, avaliação do desempenho de IFM significa olhar igualmente para essas duas linhas: alcance social e sustentabilidade financeira.

Duas abordagens ou paradigmas orientam o debate em torno do desempenho da indústria de microfinanças: a abordagem dos desenvolvimentistas, a qual argumenta que a redução da pobreza deve ser o principal objetivo das IMFs e o paradigma institucionalista ou abordagem minimalista, que defende o objetivo da autossustentabilidade como prioridade (Kar, 2010). 
Quanto ao conceito de sustentabilidade financeira de IMFs ou desempenho financeiro, não há muita polêmica entre os estudiosos da área sendo quase consensual o seu entendimento como a capacidade que a IMF tem de se autos sustentar sem depender de subsídios ou doações. Para Kar (2010), sustentabilidade de IMF é amplamente definida como a capacidade de cobrir os custos e continuar as operações sem recorrer à ajuda filantrópica ou de subsídios.

No que se refere ao desempenho social, há mais divergência entre os autores. De maneira geral, é compreendido como a capacidade da IMF alcançar os pobres ou ainda como a prerrogativa de melhorar a vida dos clientes atendidos pelos produtos micro financeiros ofertados, sobretudo o crédito.

Consoante a isso, os estudos empíricos sobre desempenho de IMFs também adquiriram um caráter dual: de um lado, os estudos que defendem a abordagem welfarista (Welfare State ou Estado do Bem-estar) tentam buscar evidências para o argumento de que a busca pelo desempenho financeiro causa um impacto negativo sobre o alcance aos pobres (Hermes et al., 2009; Hume \& Mosley, 1996; Woller, 2002). Por outro lado, a defesa dos institucionalistas de que IMFs sólidas e financeiramente sustentáveis são capazes de fornecer serviços financeiros para as pessoas mais pobres por mais tempo é investigada em estudos como os de Christen, Rhyne, Vogel \& McKean (1995) e Robinson (2001).

Nessa perspectiva, os estudos dividem-se entre os que acreditam haver trade-off entre desempenho financeiro e desempenho social, e os que afirmam que há sinergia entre as duas linhas de atuação das IMFs, sendo possível ao mesmo tempo alcançar ou maximizar os dois tipos de resultado, a saber, sustentabilidade financeira e alcance aos pobres.

Esta pesquisa estuda de forma mais aprofundada as cooperativas de crédito, que antes mesmo de serem atores relevantes das ações de microfinanças e microcrédito no mundo, já possuíam a característica intrínseca de ser double bottom line. Conforme Louis, Seret e Baesens (2013), em última análise, ambos os grupos (welfaristas e institucionalistas) querem maximizar o impacto social, porém diferem quanto à forma de alcançar este objetivo.

Os principais objetivos dos programas de microcrédito, segundo Meyer (2002), são alcançar o maior número possível de indivíduos pobres, ser sustentável financeiramente e gerar impacto positivo na qualidade de vida dos clientes, seja por meio de aumento de renda, melhoria da qualidade de vida, alfabetização, entre outros. Para Christen e Rosenberg (2000), a autossuficiência financeira é uma condição indispensável para aumentar o alcance aos pobres uma vez que essa autonomia financeira viabiliza o crescimento das operações.

Alguns estudiosos argumentam que alcançar os "mais pobres dos pobres" é mais caro devido ao alto custo unitário dos empréstimos relativamente pequenos (Conning, 1999; 
Schreiner, 2002; Von Pischke, 1996). Assim haveria trade-off, pois ao buscar maior alcance (atingir mais mutuários pobres) as IMFs teriam pior desempenho financeiro.

A possibilidade de uma IMF obter lucros enquanto atende às demandas dos pobres foi estudada por Cull, Demirgüç-Kunt e Morduch (2007). Eles usaram um conjunto de dados de 124 IMFs de 49 países em desenvolvimento para o período compreendido entre 1999 e 2002. Os resultados mostraram que taxas de juros muito altas nem garantem uma maior rentabilidade, nem a minimização de custos. Constataram também que as instituições que fazem empréstimos menores não são necessariamente menos rentáveis. O estudo conclui, portanto, que há sinergia entre a busca do lucro e o alcance aos pobres. Outros estudos (Brau \& Woller, 2004; Schreiner, 2002) encontraram associação positiva entre rentabilidade e sustentabilidade com alcance aos pobres. Gutiérrez-Nieto, Serrano-Cinca, e Molinero (2007) também investigaram o trade-off entre eficiência social e financeira e encontraram uma baixa relação positiva entre a eficiência social e a eficiência financeira. Quayes (2012) descobre uma relação positiva entre a profundidade do alcance e a autossuficiência financeira. Já os estudos de Hartarska e Nadolnyak (2007) e Mersland e Strøm (2009) não encontraram nenhuma relação entre a sustentabilidade de uma IFM e o seu alcance.

Louis et al. (2013) averiguaram a associação entre a eficiência social e desempenho financeiro em uma amostra de 650 instituições de microfinanças e também encontraram evidências de uma relação positiva e significativa entre a eficiência social e o desempenho financeiro. Montgomery e Weiss (2011), com base em dados de famílias do Paquistão rural, concluíram que as IMFs de orientação comercial podem satisfazer o objetivo do double bottom line, ou seja, simultaneamente obtêm lucros e atingem sua missão social.

Outra discussão divergente entre os welfaristas e os institucionalistas diz respeito à “fuga da missão" (mission drift), ou seja, os defensores desta abordagem advogam que há trade-off entre a sustentabilidade financeira e o alcance. Ademais, afirmam que a busca pela sustentabilidade ou desempenho financeiro leva a uma "fuga da missão" social das IMFs. Equivale a levantar a questão sobre se as IMFs se afastaram da sua missão mais habitual de servir aos clientes mais pobres na busca por atingir a autossuficiência financeira. De acordo com Kar (2010), “fuga da missão” significa um afastamento pela IMF dos objetivos originais de atender mais clientes mulheres, clientes em áreas rurais e o não uso da metodologia de empréstimo em grupo, compromissos sociais originais das IMFs. Mersland e Strøm (2010), em seu estudo empírico, não encontraram evidências de "fuga da missão" nas IMFs analisadas. 
Referente a esse aspecto, Bédécarrats et al. (2011) afirmam que existem muitas visões contraditórias acerca da possibilidade de sinergia entre sustentabilidade financeira e alcance de objetivos sociais por parte das instituições de microfinanças.

Para autores como Lapenu (2007), há uma sinergia entre os resultados sociais e financeiros alcançados pelas IMFs, tendo em vista que o desempenho social melhora os níveis de participação e de satisfação dos clientes, levando a menores taxas de inadimplência e a também menores custos de transação. Bédécarrats et al. (2011) também investigaram o tradeoff entre desempenho financeiro e desempenho social e concluíram que há compatibilidade entre eles. Portanto, o double bottom line não é "missão impossível" e pode ser alcançado quando os trade-offs e sinergias são habilmente combinados seguidos de uma estratégia de gestão de desempenho social bem planejada.

No Brasil, os estudos sobre desempenho de instituições microfinanceiras se concentram mais na análise da sustentabilidade das instituições (Faxine, 2005; Lesmam e Carmona, 2008, dentre outros). Os estudos sobre o possível trade-off ainda são poucos (Borba, 2012).

Em síntese, os resultados dos estudos analisados são bastante heterogêneos, não sendo possível apresentar evidências empíricas suficientes para se chegar a um consenso em torno do debate apresentado.

\subsubsection{Desempenho Financeiro de IMFs}

Em relação ao desempenho financeiro de IMF, embora não haja consenso, há convergência em relação à sua definição. Ledgerwood (1999) considera que o desempenho de uma IMF indica o quão bem uma instituição administra as suas operações. Woller (2002) observa que atingir a eficiência operacional é fundamental para as IMFs, uma vez que isso contribui para a autossustentabilidade delas. Consultative Group to Assist the Poorest (CGAP, 2003) ressalta a necessidade das IMFs alcançarem a eficiência nas suas operações, ao afirmar que a baixa eficiência nas operações pode fazer com que as taxas de juros cobradas sejam maiores do que o necessário.

No que concerne às métricas usadas para a sua mensuração, também não se encontraram muitas divergências nos trabalhos analisados. Em geral, utilizam-se indicadores contábeis, sendo os mais clássicos Retorno sobre o Ativo $(R O A)$, Retorno sobre o Patrimônio Líquido $(R O E)$, custo operacional e taxa de inadimplência. 
Ledgerwood (1999), ao realizar pesquisa para o Banco Mundial, definiu um conjunto de indicadores para avaliação de desempenho financeiro de IMFs, os quais foram classificados em quatro grupos, quais sejam: qualidade da carteira de crédito, eficiência e produtividade da IMF; viabilidade financeira; lucratividade; alavancagem financeira e adequação de capital; e escala, alcance e crescimento. Conforme a autora citada, o grupo qualidade da carteira seria composto por indicadores como taxa de adimplência, percentual da carteira em risco e taxa de incobráveis; o grupo de indicadores referente à eficiência e produtividade seria formado pelos indicadores total de empréstimos por agente de crédito além da razão entre os custos operacionais e o volume de empréstimos; quanto ao grupo viabilidade financeira, estaria composto por indicadores como spread financeiro, autossuficiência operacional, autossuficiência financeira e índice de dependência de subsídios; o grupo relacionado à lucratividade seria formado pelos indicadores de rentabilidade tradicionais, como retorno sobre o ativo total e retorno sobre o patrimônio líquido; no que se refere ao grupo de indicadores relacionados à alavancagem financeira e adequação do capital, seria formado pela razão entre capital de terceiros e capital próprio, e capital e investimentos em ativos de risco; por fim, no que tange à escala, alcance e crescimento das operações, os indicadores que o compõem são quantidade e localização de agências, volume de empréstimos realizados, valor médio dos empréstimos realizados, número de clientes, dentre outros.

Armendáriz e Morduch (2010) selecionaram alguns índices financeiros para comparar o desempenho financeiro das instituições de microfinanças, dentre eles destacam-se: (a) Retorno sobre Ativo ( $R O A)$, o qual indica o quão bem uma instituição utiliza seus ativos totais para gerar retornos; (2) Carteira em risco ou inadimplência, que mede o valor de todos os empréstimos vencidos há mais do que um determinado número de dias e; (3) Rendimento da carteira de crédito bruta. Rosenberg (2009) recomenda as seguintes variáveis para a mensuração do desempenho social: adimplência (qualidade da carteira); sustentabilidade financeira (rentabilidade - $R O A$ e $R O E$ ) e eficiência. Bédécarrats et al. (2011) utilizaram para analisar o desempenho financeiro de IMFs as variáveis: produtividade, qualidade da carteira, taxa de despesa operacional, retorno sobre ativos e autossuficiência operacional. Kipesha e Zhang (2013) usaram nove indicadores como proxies para a sustentabilidade e rentabilidade das instituições de microfinanças. Os indicadores incluem autossuficiência operacional, o retorno sobre ativos $(R O A)$, o rendimento da carteira de crédito bruta, despesas operacionais em relação aos ativos, valor da carteira de crédito bruta, taxa de empréstimos ativos, índices de endividamento, custo por mutuário. Barry e Tacneng (2014) utilizaram, para medir o 
desempenho financeiro, variáveis como rentabilidade (ROA, eficiência operacional) $\mathrm{e}$ eficiência das IMFs.

Existem ainda os indicadores criados por instituições como a MIX e o CGAP, além da CERISE. Esta última se preocupa mais com os indicadores de desempenho social.

No Brasil, o BNDES, por meio do Programa de Desenvolvimento Institucional (PDI), elaborou uma coletânea de índices como sugestão para utilização em organizações de microcrédito (Bruett, Summerlin, \& D’Onófrio, 2002).

Borba (2012), em seu estudo sobre o trade-off entre desempenho financeiro e social, utilizou como variáveis de desempenho financeiro Retorno sobre o Ativo Total $(R O A)$, Retorno sobre o Patrimônio Líquido ( $R O E)$, taxa de incobráveis, percentual da carteira em risco maior que 30 dias, eficiência operacional (razão entre despesas operacionais e valor da carteira de crédito), dentre outros.

Os indicadores criados pela $S P T F$ e sintetizados pela $M I X$ são considerados um avanço e têm sido amplamente utilizados na maior parte dos estudos aqui referenciados. Estes índices englobam aspectos como características institucionais, estrutura de financiamento, escala, desempenho financeiro geral (rentabilidade), análise das receitas e despesas, eficiência e produtividade, risco e liquidez. A $M I X$ sintetizou esses aspectos em quatro grupos, a saber: Qualidade dos Ativos, Eficiência e Produtividade, Gestão Financeira e Lucratividade.

Para efeito desta pesquisa, os dados coletados permitiram analisar somente os pertencentes a três destes grupos, e não foi possível também analisar o aspecto produtividade. Portanto, os grupos de indicadores analisados neste estudo são: qualidade dos ativos, eficiência e lucratividade. Este último considerado como rentabilidade, uma vez que o termo lucratividade não é muito apropriado para o tipo de instituição aqui analisado (cooperativas de crédito).

\section{- Qualidade dos Ativos}

Este primeiro grupo de indicadores de desempenho de IMFs inclui a qualidade da carteira e, de acordo com a classificação da $M I X$, considera aspectos como a avaliação de risco de crédito. Segundo Bruett et al. (2002), em finanças frequentemente usa-se o indicador carteira em risco (portfolio at risk), o qual reflete o risco dos empréstimos em atraso. Nas palavras do autor, é a parte da carteira contaminada por pagamentos em atraso ou que correm o risco de não serem pagos. 
A carteira em risco ou inadimplência é o indicador mais aceito pela literatura e mais testado em estudos empíricos. Para efeito desta pesquisa, considerou-se a inadimplência em valores e taxa de inadimplência como proxies para a qualidade dos ativos. Considera-se inadimplência os contratos vencidos há mais de 90 dias. A taxa de inadimplência representa a razão entre o saldo total de todos os empréstimos em atraso acima de 90 dias e o saldo total da carteira ativa.

\section{- Rentabilidade}

A rentabilidade, também considerada lucratividade, retrata o aspecto econômico da instituição uma vez que relaciona os resultados obtidos com valores que expressam a dimensão relativa do mesmo (valor de vendas, ativo total, patrimônio líquido ou ativo operacional) (Iudícibus 2009). Para a $M I X$, a rentabilidade da carteira mensura o quanto a IMF recebeu de juros e multas pelos empréstimos.

Esta pesquisa definiu como proxies para este indicador as seguintes variáveis: $R O A$, $R O E$, margem de rentabilidade da carteira de crédito, rendas de juros com operações de crédito em relação ao ativo total ajustado e resultado da intermediação financeira.

\section{- Eficiência}

O terceiro grupo de indicadores de desempenho de IMFs, denominado pela $M I X$ Eficiência e Produtividade, é aqui considerado somente Eficiência, dadas as limitações quanto à análise de produtividade. A eficiência de uma instituição, do ponto de vista das finanças, mede a relação custo/benefício ou, como destaca Bruett et al. (2002), mensura a capacidade de uma IFM fornecer seus produtos e serviços ao menor custo possível e considera aspectos como margem operacional e custo operacional. A margem operacional é considerada por Martins et al. (2014) um importante sinalizador de rentabilidade para organizações em geral, tendo em vista que indica o percentual das vendas convertido em lucro. No entanto, esta pesquisa adota a classificação da $M I X$ e, por conseguinte, considera-se neste estudo as variáveis custo operacional e margem operacional como proxies da eficiência de instituições de microfinanças. 
Por desempenho social de IMFs entende-se, grosso modo, a capacidade de a instituição atingir os mais pobres sendo também utilizado como sinônimo de desempenho social o termo alcance. Conning (1999) define alcance como a concessão de empréstimos e outros serviços financeiros para o maior número possível de clientes e também para os "mais pobres dos pobres" e considera que o alcance tem duas dimensões: profundidade e amplitude. Para o autor, a profundidade do alcance refere-se a quanto os clientes atendidos estão abaixo da linha da pobreza; e amplitude, ao número de clientes alcançados.

Como dito anteriormente, o desempenho desse tipo de instituição tem duas dimensões: uma social, razão da sua própria existência; e outra econômico-financeira, necessária para a sua sustentabilidade. Para efeito deste trabalho, considera-se a abordagem do Grupo de Trabalho de Desempenho Social, SPTF (Social Performance Task Force), que em conjunto com a MIX, definem o desempenho de IMCs como double bottom line (linha de fundo duplo). Significa dizer que as IMCs visam igualmente atingir resultados financeiros e sociais positivos. Para Bédécarrats et al. (2011), o desempenho social mede o nível de dedicação de uma instituição de microfinanças ao cumprimento de sua missão social.

O desempenho social abordado por estudos anteriores (Meyer, 2002; Navajas, Schreiner, Meyer, Gonzalez-Vega, \& Rodriguez-Meza, 2000) é mensurado de diferentes formas. Navajas et al. (2000) consideraram seis aspectos para medir o alcance de uma instituição de microfinanças, dentre eles, o custo para os usuários. No entanto, de acordo com Quayes (2012), as dimensões do desempenho social de IMFs mais utilizadas são a amplitude do alcance (breadth) e a profundidade (depth) do alcance do microcrédito. Amplitude do alcance significa viabilizar os benefícios sociais do microcrédito para clientes pobres (Schreiner, 2002), e profundidade do alcance é o quanto, realmente, o microcrédito alcança "os mais pobres entre os pobres" (Bassem, 2009; Hartarska, 2005).

Quanto às medidas de desempenho social de IMFs, é somente no início dos anos 2000 que surgem iniciativas para promover o desenvolvimento de ferramentas de mensuração e de gerenciamento do desempenho social e consideram a primeira iniciativa a da SPTF De acordo com Bédécarrats et al. (2011), Ainda conforme os autores, a proposta da SPTF deriva do Indicador de Desempenho Social (SPI), desenvolvido em 2004, o qual recolhe dados de 70 indicadores que foram sistematizados pela SPTF em quatro dimensões: 1) focalização e alcance (atingir os pobres e excluídos); 2) Adaptação dos serviços (ofertar serviços financeiros adequados às necessidades dos clientes); 3) Benefícios para os clientes (não apenas econômicos, mas promover o envolvimento e participação do cliente além do seu empoderamento) e; 4) Responsabilidade Social das instituições de microfinanças (para com 
os empregados, a garantia de políticas adequadas de recursos humanos; para com os clientes, o respeito dos princípios de proteção ao consumidor e para com a comunidade e o ambiente, respeitando a cultura e o contexto em que a IMF atua).

Todavia, desenvolver estudos que comtemplem todas essas dimensões não é tarefa fácil devido à escassez de dados. Vanroose e D’Espallierc (2013) reconhecem que não há dados que viabilizem estudos mais aprofundados de mensuração de impacto. Assim, o setor de microfinanças utiliza frequentemente o tamanho médio do empréstimo em relação ao PIB per capita como uma proxy para a mensuração do alcance aos pobres.

Com efeito, as dimensões do alcance mais utilizadas nos estudos empíricos analisados são a profundidade e a amplitude do alcance. Profundidade do alcance se refere a servir as pessoas mais pobres. Já a amplitude significa servir a um grande número de pessoas, mesmo que elas não sejam os “mais pobres dos pobres” (Brau \& Woller, 2004; Schreiner, 2002).

Para mensurar a amplitude do alcance, as variáveis mais utilizadas nos estudos analisados são o número de clientes atingidos, valor médio do empréstimo e percentual de mutuários do sexo feminino (Hartarska \& Nadolnyak, 2007; Luzzi \& Weber, 2006; Luzzi \& Weber, 2007; Mersland \& Strøm, 2009).

Apesar de Schreiner \& Yaron (1999) utilizarem o alcance (outreach), uma proxie para o desempenho social, Schreiner (2002) foi um dos dos primeiros autores a proporem um conjunto mais amplo de indicadores de desempenho social, os quais estão relacionados a seis dimensões de alcance: amplitude, profundidade, comprimento, escopo, custo e valor de divulgação para clientes e comunidade. $\mathrm{O}$ autor define alcance como a capacidade de levar os benefícios sociais de microcrédito a clientes pobres e, em seu estudo, encontrou evidências empíricas de que as IMFs sem fins lucrativos têm maior profundidade do alcance ao passo que as IMFs que procuram lucro têm abrangência maior.

Kar (2010) considerou três dimensões do alcance: a amplitude, o custo e a profundidade. Definiu amplitude do alcance como o número absoluto de clientes pobres; e profundidade do alcance, como uma forma de medir se houve melhoria na qualidade dos serviços prestados pela IMF assim como na satisfação dos clientes. O custo do alcance é a soma de todos os custos, inclusive dos de transação. A amplitude do alcance foi mensurada por meio do total de empréstimos; e a profundidade do alcance, pelo tamanho médio de empréstimo ajustado pelo PIB per capita.

Rosenberg (2009) recomenda as seguintes variáveis para a mensuração do alcance: amplitude, medida por meio do número de clientes atendidos; e profundidade, mensurada pelo nível de pobreza do cliente. 
Hartarska (2005) examina o efeito do tamanho da IMF na profundidade e na amplitude do alcance. Os resultados indicam que não existe uma relação significativa entre o tamanho da IMF e seu alcance em termos de profundidade e amplitude.

Já o estudo de Mersland e Strøm (2009) indica que o tamanho da IMF afeta positiva e negativamente a amplitude e a profundidade do alcance, respectivamente. Mersland e Strøm (2010) sugerem a existência de trade-off entre o desempenho financeiro e o alcance aos pobres.

Hermes, Lensink e Meesters (2011) usaram uma amostra de 435 IMFs que operam em diferentes países e encontraram evidências de uma relação negativa entre a eficiência de custos e a profundidade do alcance e, portanto, concluíram que servir aos clientes mais pobres reduz a eficiência.

Barry e Tacneng (2014) também investigaram o alcance de IMFs sendo este definido por eles como os benefícios sociais das microfinanças. Consideraram também os dois aspectos do alcance: amplitude e profundidade. Usaram duas medidas para a profundidade do alcance: valor médio do empréstimo em relação ao PIB per capita e porcentagem de mulheres, e para a amplitude, o tamanho do empréstimo.

No Brasil, Borba (2012) criou o Indicador de Desempenho Social de Instituições de Microfinanças (ISM), o qual foi construído com base em dados dos Relatórios Padrão de Desempenho Social elaborados segundo o modelo da $M I X$ de instituições de microfinanças atuantes na América Latina. O índice foi composto por 30 perguntas binárias e objetivas, e cada resposta positiva adicionava dois pontos ao indicador - as instituições poderiam apresentar um desempenho social de 0 a 60 pontos. $\mathrm{O}$ autor apontou as limitações do indicador, a saber: os dados limitaram-se aos fornecidos por meio dos Relatórios Padrão de Desempenho Social elaborados segundo a metodologia $M I X$ e divulgados pelas instituições. Além disso, o indicador foi construído com base apenas nas questões relacionadas ao nível de atuação social das instituições não abordando informações sobre o grau de pobreza da comunidade atendida.

Quayes (2012) utilizou como proxy para a profundidade do alcance o tamanho médio do empréstimo por tomador. $\mathrm{O}$ autor mediu a amplitude do alcance por meio do número de mutuários e pelo percentual de mutuários mulheres. A profundidade do alcance foi definida como o acesso ao crédito pelos pobres. O autor ressalta que a principal limitação para a mensuração da profundidade do alcance é a falta de dados para medir o nível de pobreza dos beneficiários do microcrédito. $\mathrm{Na}$ ausência ou escassez desses dados, a medida mais amplamente utilizada para medir a profundidade do alcance tem sido o empréstimo por 
tomador, ou valor médio dos empréstimos. Quanto menor é o tamanho do empréstimo, mais pobre é o tomador. Em sínese, o autor define a amplitude do alcance como a mensuração da "quantidade" de microcrédito, enquanto a profundidade do alcance mede a "qualidade" do microcrédito.

Esta pesquisa utiliza as definições e as proxies para a mensuração do desempenho social (alcance) utilizadas por Quayes (2012).

Os conceitos, teorias e a revisão de literatura apresentados neste capítulo tiveram o propósito de apresentar os aspectos das microfinanças e do microcrédito considerados relevantes e necessários à compreensão e análise do objetivo do presente estudo, o qual é sustentado pelas teorias e conceitos convergentes e estudos análogos apresentados. A Figura 15 apresenta uma síntese dos principais estudos referenciados. 


\begin{tabular}{|c|c|c|c|}
\hline Autoria & Metodologia & Fonte de dados & Conclusões \\
\hline Alinsunurin (2014) & $\begin{array}{l}\text { Análise Envoltória de } \\
\text { Dados }(D E A)\end{array}$ & $\begin{array}{l}\text { MIX Market, } 41 \text { IMFs nas } \\
\text { Philippinas, em } 2011\end{array}$ & $\begin{array}{l}\text { Os resultados demonstraram que não existe qualquer IMF que pode ser eficiente em todas as } \\
\text { saídas especificadas; algumas MFIs são financeiramente eficientes, mas têm que utilizar mais } \\
\text { de seus insumos em chegar a mais clientes potenciais. Além disso, as ONGs parecem ser } \\
\text { financeiramente menos eficientes do que os outros tipos de IMFs. }\end{array}$ \\
\hline $\begin{array}{l}\text { Barry e Tacneng } \\
(2014)\end{array}$ & $\begin{array}{l}\text { Regressão com dados em } \\
\text { painel }\end{array}$ & $\begin{array}{l}\text { MIX Market, 200 IMFs localizadas } \\
\text { em } 30 \text { países da África } \\
\text { Subsaariana, de } 2001 \text { a } 2007\end{array}$ & $\begin{array}{l}\text { Os resultados indicaram que as ONGs são mais rentáveis e têm melhor alcance do que bancos } \\
\text { e cooperativas. }\end{array}$ \\
\hline $\begin{array}{l}\text { Bédécarrats, Baur e } \\
\text { Lapenu (2011) }\end{array}$ & Regressão & $\begin{array}{l}\text { Dados de auditorias sociais de } \\
2006 \text { até } 2011 \text {, obtidos de } 344 \\
\text { avaliações SPI de } 295 \text { IMFs } \\
\text { diferentes em } 51 \text { países em todo o } \\
\text { mundo (MIX e CERISE) }\end{array}$ & $\begin{array}{l}\text { Os dados confirmaram que desempenho social e desempenho financeiro são compatíveis. } \\
\text { Portanto, a linha de fundo duplo não é "missão impossível”, mas pode ser alcançado quando os } \\
\text { trade-offs e sinergias são combinados de forma inteligente na sequência de uma estratégia de } \\
\text { gestão de desempenho social bem planejada. }\end{array}$ \\
\hline Borba (2012) & $\begin{array}{l}\text { Regressão com dados em } \\
\text { painel }\end{array}$ & $\begin{array}{l}\text { MIX Market, IMFs da América } \\
\text { Latina, entre os anos de } 2008 \text { e } \\
2009\end{array}$ & $\begin{array}{l}\text { Não foi possível estabelecer uma relação entre desempenho financeiro e desempenho social. } \\
\text { Os achados revelaram a importância da variável tamanho para a IMF obter resultados } \\
\text { financeiros e sociais superiores. }\end{array}$ \\
\hline Bos e Millone (2015) & Modelo de Regressão & $\begin{array}{l}\text { MIX Market, } 1.146 \text { IMFs durante o } \\
\text { período de } 2003 \text { a } 2010 \\
\text { Variáveis: desempenho financeiro, } \\
\text { profundidade do alcance (tamanho } \\
\text { médio do empréstimo) e a } \\
\text { amplitude do alcance (o número de } \\
\text { empréstimos) }\end{array}$ & $\begin{array}{l}\text { Os resultados empíricos mostram que existem importantes trade-offs entre o desempenho } \\
\text { social e financeiro em microfinanças. Concluem ainda que, para essa amostra, a "fuga da } \\
\text { missão" não só diminui a profundidade, mas também a amplitude do alcance. Além disso, } \\
\text { evidenciaram que as IMFs sem fins lucrativos são mais eficientes do que as com fins } \\
\text { lucrativos. }\end{array}$ \\
\hline $\begin{array}{l}\text { Cull, Demirgüç-Kunt } \\
\text { e Morduch (2007) }\end{array}$ & $O L S$ & $\begin{array}{l}\text { MicroBanking Bulletin, } 124 \text { MFIs, } \\
49 \text { países, 1999-2002 }\end{array}$ & Há trade-off, mas a magnitude depende do tipo de empréstimo. \\
\hline $\begin{array}{l}\text { Gakhar e Meetu } \\
(2013)\end{array}$ & $\begin{array}{l}\begin{array}{l}\text { Regressão com dados em } \\
\text { painel }\end{array} \\
\end{array}$ & $\begin{array}{l}\text { MIX Market, } 40 \text { IMFs indianas, } \\
\text { período de } 8 \text { anos (2004-2011) }\end{array}$ & $\begin{array}{l}\text { Os resultados mostraram que as instituições de microfinanças (IMFs) podem realmente atingir } \\
\text { seu duplo objetivo de alcance e desempenho financeiro. }\end{array}$ \\
\hline $\begin{array}{l}\text { Gutiérrez-Nieto, } \\
\text { Serrano-Cinca e } \\
\text { Molinero (2007) }\end{array}$ & $D E A$ & $\begin{array}{l}\text { MIX Market, } 89 \text { IMFs, número de } \\
\text { países desconhecido, } 2003\end{array}$ & Os achados mostraram baixa relação positiva entre o alcance e a eficiência financeira. \\
\hline $\begin{array}{l}\text { Hartarska, } \\
\text { Nadolnyak e Shen, } \\
\text { 2012). }\end{array}$ & $\begin{array}{l}\text { Regressão com dados, } \\
\text { painel desbalanceado } \\
\text { (Estimativa da Função } \\
\text { Custo) }\end{array}$ & $\begin{array}{l}\text { MIX Market, } 216 \text { IMFs } \\
\text { cooperativas de } 41 \text { países para o } \\
\text { período de } 2003 \text { a } 2010\end{array}$ & $\begin{array}{l}\text { Os resultados mostraram que as cooperativas de microfinanciamento têm retornos crescentes } \\
\text { de escala, o que significa que a grande maioria pode reduzir custo, se eles se tornam maiores. }\end{array}$ \\
\hline $\begin{array}{l}\text { Hermes, Lensink e } \\
\text { Meesters (2011) }\end{array}$ & $\begin{array}{l}\text { Análise de fronteira } \\
\text { estocástica }\end{array}$ & $\begin{array}{l}\text { MIX Market, } 435 \text { IMFs, número de } \\
\text { países desconhecido, 1997-2007 }\end{array}$ & Encontraram trade-off: Mais eficiência financeira implica menor alcance. \\
\hline
\end{tabular}




\begin{tabular}{|c|c|c|c|}
\hline Autoria & Metodologia & Fonte de dados & Conclusões \\
\hline $\begin{array}{l}\text { Kipesha e Zhang } \\
\text { (2013) }\end{array}$ & $\begin{array}{l}\text { Regressão com dados em } \\
\text { painel }\end{array}$ & $\begin{array}{l}\text { MIX Market, } 47 \text { IMFs que operam } \\
\text { nos países do Leste Africano, } 2008 \\
\text { a } 2011\end{array}$ & $\begin{array}{l}\text { Na perspectiva welfarista, o estudo descobriu que o foco em rentabilidade tem um impacto } \\
\text { negativo sobre o alcance aos pobres, o que implica a presença de trade-off. Sob a visão } \\
\text { institucionalista, o alcance aos pobres tem uma relação positiva com medidas tanto de } \\
\text { sustentabilidade como de rentabilidade. Constatou ainda que o trade-off entre desempenho } \\
\text { financeiro e alcance aos pobres também depende das variáveis utilizadas e da especificação } \\
\text { modelo de estimativa. }\end{array}$ \\
\hline $\begin{array}{l}\text { Louis, Seret e } \\
\text { Baesens (2013) }\end{array}$ & $\begin{array}{l}\text { SOM (Self-organizing } \\
\text { maps) - Mapas de } \\
\text { Kohonen }\end{array}$ & MIX Market, 650 IMFs, 2011 & $\begin{array}{l}\text { Encontraram associação (relação positiva e significativa) entre o desempenho financeiro e o } \\
\text { social. }\end{array}$ \\
\hline $\begin{array}{l}\text { Luzzi e Weber } \\
(2007)\end{array}$ & $\begin{array}{l}\text { Análise fatorial para a } \\
\text { construção dos } \\
\text { indicadores e, em } \\
\text { seguida, equações } \\
\text { simultâneas }\end{array}$ & $\begin{array}{l}45 \text { instituições de microfinanças de } \\
\text { diferentes países pesquisadas pelo } \\
\text { Instituto Universitário de Estudos } \\
\text { do Desenvolvimento de Genebra } \\
\text { para o período 1999-2003 }\end{array}$ & $\begin{array}{l}\text { O objetivo do trabalho foi mostrar alternativas de ferramentas estatísticas para a avaliação de } \\
\text { desempenho de IMFs. Tentaram encontrar possíveis determinantes das medidas de } \\
\text { desempenho financeiro e social (alcance), mas consideraram a escassez de dados um limitador } \\
\text { da confiabilidade estatística da pesquisa. }\end{array}$ \\
\hline Marakkath (2014) & $\begin{array}{l}\text { Método misto: } \\
\text { abordagem quantitativa, } \\
\text { usando análise de } \\
\text { regressão múltipla e } \\
\text { análise discriminante } \\
\text { múltipla e análise } \\
\text { qualitativa com } \\
\text { entrevistas em quatro } \\
\text { IMFs }\end{array}$ & $\begin{array}{l}\text { MIX Market, } 50 \text { IMFs indianas, de } \\
2005 \text { a } 2009\end{array}$ & $\begin{array}{l}\text { Conclui que a sustentabilidade, para as IMFs indianas, é um meio para alcançar seus objetivos } \\
\text { sociais e não o contrário. }\end{array}$ \\
\hline $\begin{array}{l}\text { Mersland e Strøm } \\
(2010)\end{array}$ & $\begin{array}{l}\text { Dados em painel com } \\
\text { variáveis instrumentais }\end{array}$ & $\begin{array}{l}\text { Ratingfund }^{17}, 379 \text { MFIs, } 74 \\
\text { countries, 1998-2008 }\end{array}$ & $\begin{array}{l}\text { Não encontraram evidências de trade-off e sim que mais eficiência financeira pode levar a } \\
\text { melhor alcance. }\end{array}$ \\
\hline $\begin{array}{l}\text { Nurmakhanova, } \\
\text { Kretzschmar e } \\
\text { Fedhila (2015) }\end{array}$ & $\begin{array}{l}\text { Modelo de equações } \\
\text { simultâneas }\end{array}$ & $\begin{array}{l}\text { MIX Market e Microbanking } \\
\text { Bulletin, } 450 \text { IMFs de } 71 \text { países } \\
\text { durante o período de } 2006 \text { a } 2008\end{array}$ & $\begin{array}{l}\text { Analisaram os determinantes do desempenho financeiro e social de IMFs e investigaram se } \\
\text { haveria trade-off. Os resultados mostraram que o foco na sustentabilidade financeira não } \\
\text { necessariamente fere a profundidade e a amplitude do alcance. Com base nesse resultado, a } \\
\text { proposição do "win-win" para as instituições de microfinanças é alcançável. }\end{array}$ \\
\hline Quayes (2012) & $O L S$, regressão logística & $\begin{array}{l}\text { MIX Market, } 702 \text { MFIs, } 83 \text { países, } \\
2006\end{array}$ & $\begin{array}{l}\text { Os resultados mostraram que a sustentabilidade financeira tem um impacto positivo sobre a } \\
\text { profundidade do alcance para as IMFs de alto disclosure e relação negativa para as empresas } \\
\text { de baixo disclosure. }\end{array}$ \\
\hline
\end{tabular}

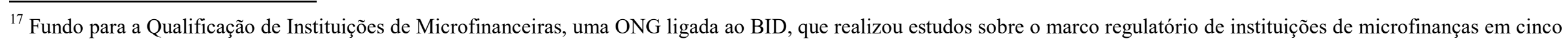
países da América Latina: Bolívia, Equador, México, Nicarágua e Peru, e encerrou suas operações em 2012.
} 


\begin{tabular}{|c|c|c|c|}
\hline Autoria & Metodologia & Fonte de dados & Conclusões \\
\hline $\begin{array}{l}\text { Vanroose e } \\
\text { D'Espallierc (2013) }\end{array}$ & $\begin{array}{l}\text { Regressão com dados em } \\
\text { painel }\end{array}$ & $\begin{array}{l}\text { MIX Market, } 1073 \text { IMFs de todos } \\
\text { os tipos e em todas as regiões ao } \\
\text { longo de } 10 \text { anos (1997 a 2006) }\end{array}$ & $\begin{array}{l}\text { O artigo analisa a relação entre o alcance e o desempenho das instituições de microfinanças. } \\
\text { Por um lado, os resultados mostram que as IMFs chegam a mais clientes onde o setor } \\
\text { financeiro tradicional é menos desenvolvido. Isto sugere que as IMFs satisfazem uma } \\
\text { necessidade que o setor bancário tradicional não contempla, em linha com a sua missão e com } \\
\text { a hipótese das falhas do mercado. Por outro lado, em países com mercados financeiros bem } \\
\text { desenvolvidos, as IMFs parecem estar em concorrência mais direta com os bancos. Isso resulta } \\
\text { em menor número de sensibilização, mas também tamanhos de empréstimo média mais baixos } \\
\text { e, portanto, alcance mais profundo, mais uma vez, de acordo com a sua missão. }\end{array}$ \\
\hline
\end{tabular}

Figura 15: Quadro Síntese dos Estudos sobre Desempenho de Instituições de Microfinanças.

Fonte: Elaboração própria. 


\subsection{Hipóteses da pesquisa}

Tendo em vista os objetivos propostos por este estudo, considerando ainda evidências encontradas por estudos anteriores, além dos fundamentos teórico-conceituais discutidos neste capítulo, elaboraram-se as seguintes hipóteses estatísticas relacionadas às variáveis representativas dos grupos de indicadores a serem testadas:

\section{- Qualidade dos Ativos}

No que se refere a este grupo de indicadores, as variáveis a serem testadas são: inadimplência - carteira em risco $>90$ dias $(I N A D)$; margem de intermediação financeira (MARG_FIN); rendas de juros com operações de crédito em relação ao ativo total ajustado $\left(R E N D \_J R\right)$; rentabilidade da carteira de crédito (RENT_CART); resultado da intermediação financeira (RESULT_FIN); resultado da intermediação financeira, considerando somente juros (RESULT_FIN_JR) e taxa de inadimplência (TX_INAD). Tendo em vista as mudanças regulatórias no microcrédito e com base na literatura e fundamentação teórica anteriormente apresentadas, espera-se que estas variáveis proxies deste grupo de indicadores financeiros sejam negativamente influenciadas pelas mudanças. Sabe-se que as principais mudanças ocorridas no microcrédito durante o período analisado foram a redução das taxas de juros e taxa de abertura de crédito, além da criação de subsídios para a equalização (compensação) da redução das taxas. As variáveis caracterizantes de retorno e renda tendem a decrescer em decorrência da taxa de juros mais baixa. Já a inadimplência está propensa a reduzir em função da redução na taxa de juros e com base no modelo de Stiglitz \& Weiss (1981).

Por conseguinte, as hipóteses estatísticas propostas são:

$\mathrm{H}_{1}$ (A): as variáveis proxies do grupo de indicadores financeiros, denominado qualidade dos ativos, são negativamente influenciadas pelas mudanças regulatórias do microcrédito.

\section{- Rentabilidade}

As variáveis proxies para a análise de rentabilidade são as clássicas $R O A$ - Retorno sobre Ativo (anual) e $R O E$ - Retorno sobre o Patrimônio Líquido (semestral). A metodologia do microcrédito produtivo baseada no acompanhamento da operação por um agente de crédito 
tem custo elevado. Se houve um aumento da oferta impulsionado pelas mudanças regulatórias analisadas, então o custo da operação tende a crescer, sobretudo porque as taxas de juros baixaram. Ademais, a massificação do crédito - objetivo do CRESCER - também pode gerar maiores custos administrativos em função do monitoramento dos empréstimos.

Considerando-se que a rentabilidade é afetada pelo aumento dos custos, os quais, por sua vez são influenciados pela redução das taxas de juros, supõe-se que estas variáveis, do mesmo modo que as anteriores, sejam negativamente impactadas pelas medidas analisadas como proxies para este grupo de indicadores. Sendo assim, as hipóteses estatísticas levantadas são:

$\mathrm{H}_{1}$ (B): as variáveis proxies do grupo de indicadores financeiros, nomeado rentabilidade, são negativamente influenciadas pelas mudanças regulatórias do microcrédito.

\section{- Eficiência}

No que concerne à eficiência, as variáveis a serem testadas são: custo operacional $\left(C U S T \_O P\right)$ e margem operacional $\left(M A R G_{-} O P\right)$. Neste caso, como estas duas variáveis são inversamente proporcionais, espera-se que as mudanças analisadas impactem positivamente sobre o custo, uma vez que as taxas caíram, e negativamente sobre a margem operacional pelas mesmas razões.

A eficiência de uma instituição, do ponto de vista das finanças, mede a relação custo/benefício ou, como destaca Bruett et al. (2002), mensura a capacidade de uma IMF fornecer seus produtos e serviços ao menor custo possível. Este estudo optou pelos indicadores utilizados pelo $\mathrm{BCB}$, quais sejam: margem operacional, custo operacional. Por conseguinte, as hipóteses estatísticas elaboradas são:

$\mathrm{H}_{1 \mathrm{a}}(\mathrm{C})$ : o custo operacional é positivamente influenciado pelas mudanças regulatórias do microcrédito;

$\mathrm{H}_{1 b}$ (C): a margem operacional é negativamente influenciada pelas mudanças regulatórias do microcrédito.

\section{- Desempenho social}


No que diz respeito ao desempenho social, também denominado alcance do microcrédito, é mensurado com base em duas dimensões: amplitude do alcance, que é medida por meio das variáveis total de clientes $(C L I E N)$ e total de operações $(O P E R)$ e; profundidade do alcance, que é mensurada pelas variáveis carteira ativa média $\left(M E_{-} C A\right)$ ou tamanho médio dos empréstimos e valor médio das operações $\left(M E \_O P E R\right)$. Isto posto, as hipóteses estatísticas desenvolvidas são:

$\mathrm{H}_{1 \mathrm{a}}$ (D): as variáveis proxies para a mensuração do desempenho social por meio da amplitude do alcance são positivamente influenciadas pelas mudanças regulatórias do microcrédito;

$\mathrm{H}_{1 \mathrm{~b}}$ (D): as variáveis proxies para a mensuração do desempenho social por intermédio da profundidade do alcance são negativamente influenciadas pelas mudanças regulatórias do microcrédito.

As variáveis mais utilizadas em estudos anteriores como métricas para a amplitude do alcance são o número de mutuários ativos ou de clientes atendidos (Bassem, 2009; Cull et al., 2007; Hartarska, 2005; Hartarska \& Mersland, 2012; Hartarska \& Nadolnyak, 2007; Mersland \& Strøm, 2009; Meyer, 2002; Navajas et al., 2000). A justificativa é que indivíduos que não tinham acesso a serviços financeiros formais passaram a ter com a oferta de microcrédito.

As variáveis comumente usadas em estudos empíricos para mensurar a profundidade do alcance são o tamanho médio dos empréstimos (Galema, Lensink, \& Mersland, 2012; Mersland \& Strøm, 2009; Mersland, Randøy \& Strøm, 2011) e o volume de empréstimos (Hartarska \& Mersland, 2012). O entendimento é que, quanto menor o valor médio do empréstimo, mais pobres estão sendo alcançados. 


\section{DESENHO DA PESQUISA}

Este capítulo descreve as escolhas metodológicas, assim como os procedimentos adotados para a realização deste estudo. O capítulo está estruturado em cinco seções: na primeira, discute-se, do ponto de vista epistemológico, as estratégias de pesquisa adotadas, justificando-se as escolhas; em seguida são apresentadas as variáveis de estudo e suas respectivas descrições; na segunda seção, descrevem-se os caminhos percorridos, ou seja, os procedimentos metodológicos adotados; na terceira, apresentam-se as "unidades observacionais" (cooperativas); na quarta seção, é apresentado o modelo empírico utilizado e, por fim, na quinta e última seção, expõem-se as limitações do estudo.

A pesquisa científica, de acordo com Gil (1999), pode ser classificada quanto ao objetivo, à abordagem, à lógica da investigação, à natureza da pesquisa e aos procedimentos técnicos adotados.

Nesta perspectiva, o presente estudo é assim categorizado: com relação à natureza, é uma pesquisa aplicada, posto que investiga um problema social concreto. No que tange à base de dados, é um estudo empírico, já que se utiliza de dados primários e secundários.

Em relação à lógica ou método de investigação, é um estudo hipotético-dedutivo. Nas palavras de Coelho, Soutes e Martins (2010, p. 23), este método consiste na busca de evidencias empíricas a partir de uma teoria, um modelo ou um conceito a fim de se testarem hipóteses. Conforme Martins e Theóphilo (2009), em pesquisas que utilizam esse método, a validação dos resultados é garantida pela sistematização e análise dos dados. Para Marconi e Lakatos (2003), o método hipotético-dedutivo inicia-se pela percepção de uma lacuna no conhecimento, acerca da qual se formulam hipóteses, cuja predição da ocorrência de fenômenos abrangidos por elas, é testada por meio do exercício de inferência dedutiva.

No que se refere ao objetivo, a presente pesquisa é descritiva, tendo em vista que narra e interpreta um fenômeno sem nele interferir. No que concerne à abordagem, é quantitativa, uma vez que mensura as variáveis analisadas. Marconi e Lakatos (2003) utilizam a seguinte classificação: estudo quantitativo-descritivo e exploratório-descritivo. O primeiro é definido pelas autoras como o tipo de pesquisa empírica cujo objetivo fundamental é o delineamento ou análise das características de fatos ou fenômenos. Para elas, este tipo de estudo subdividese em: (a) estudos de verificação de hipótese - contem hipóteses com declarações de associações entre duas ou mais variáveis, sem referência a uma relação causal entre elas; (b) estudos de avaliação de programas - dizem respeito à procura dos efeitos e resultados nos quais as hipóteses podem ou não estar explicitamente declaradas e com frequência derivam 
dos objetivos do programa ou método que está sendo avaliado e não da teoria. Em geral, no que tange aos procedimentos, podem se aproximar de pesquisa experimental (caso do presente estudo); (c) estudos de descrição de população - possuem, como função primordial, a exata descrição de certas características quantitativas de populações como um todo; e (d) estudos de relações de variáveis - referem-se à descoberta de variáveis pertinentes a determinada questão ou situação, ou ainda à descoberta de relações relevantes entre variáveis cujo interesse é encontrar valor preditivo. Já os estudos exploratório-descritivos são compreendidos por Marconi e Lakatos (2003) como aqueles que têm por objetivo descrever completamente determinado fenômeno, por exemplo, os estudos em que são realizadas análises empíricas e teóricas. Nesse sentido, o presente estudo pode ser definido como descritivo com abordagem quantitativa, posto que trata da avaliação dos efeitos de um programa ao tempo em que se aproxima, quanto aos procedimentos técnicos, de pesquisa experimental, sendo considerado um quasi experimento ou experimento natural. A etapa exploratória da presente pesquisa foi realizada por meio da estatística descritiva das bases de dados utilizadas. Martins (2014) diferencia a estatística descritiva da inferencial ou indutiva. Para o autor, enquanto esta faz inferências acerca de uma população com base em uma amostra representativa, a primeira apenas descreve e avalia determinado grupo, sem tirar conclusões sobre um grupo maior. Marconi e Lakatos (2003) consideram que a estatística pode ser mais do que apenas um meio de descrição racional, sendo também um método de experimentação e prova, pois é método de análise. As autoras acrescentam que a tabulação e análise descritiva dos dados permitem uma melhor compreensão e interpretação dos mesmos. Foi feito este exercício com a base de dados do MTE.

O quasi experimento, também denominado experimento natural, é definido por Martins e Theóphilo (2009) como o estudo que enfatiza a busca de relações causais entre as variáveis, embora o pesquisador não tenha controle nem sobre as variáveis de estudo e tampouco sobre as variáveis exógenas ao estudo. Esse tipo de estudo tornou-se muito utilizado em pesquisas na área de ciências sociais aplicadas, sobretudo em avaliação de políticas públicas e avaliação de impacto após o estudo econômico sobre os efeitos que ocorreram no mercado de trabalho de Miami, Estados Unidos, quando muitos encarcerados foram libertados das prisões cubanas. Os experimentos naturais nessa área de conhecimento, em geral, são utilizados quando algum fenômeno exógeno, a exemplo de uma mudança de política de governo, muda o ambiente institucional onde indivíduos, famílias, empresas e/ou municípios atuam (Wooldridge, 2010). 
Não há consenso na literatura em relação ao uso dos termos experimento e experimento natural nas ciências sociais. Shadish et al. (2002) definem experimento como um estudo em que uma intervenção é deliberadamente introduzida para lhe serem observados os efeitos. Já o experimento natural, para eles, não é propriamente um experimento, porque geralmente a causa não pode ser manipulada, ou seja, em um experimento natural geralmente se compara uma situação afetada por um evento natural, como um terremoto, com outra situação que não foi afetada pelo evento natural.

Nos estudos de impacto no segmento de microfinanças e microcrédito, o experimento com dados observacionais também tem sido amplamente utilizado. Mallick (2013) realizou um quasi experimento para investigar como os programas de microfinanças poderiam atingir os extremamente pobres em Bangladesh. Foram selecionados dois grupos, dos quais um recebeu alguns ativos como recursos financeiros e assessoria em gestão empresarial. Concluíram que esta prática habilita os extremamente pobres a se inserirem no mercado de microcrédito.

Autores como Ledgerwood (1999), ao defender o uso do experimento, assegura que, em geral, os métodos quantitativos disponíveis dividem-se em três categorias: (1) métodos experimentais; (2) métodos quase experimentais; e (3) métodos não experimentais. Os experimentais incluem apenas experimentos controlados. Os quasi experimentais abrangem os experimentos naturais ou planejados nos quais, para alguns grupos escolhidos aleatoriamente, são dados o "tratamento" ou a "intervenção", e os resultados são, então, comparados com outro também selecionado aleatoriamente, chamado de grupo de controle. As garantias da aleatoriedade são de que não há diferenças sistemáticas nem observáveis nem não observáveis entre os dois grupos.

Entretanto, como toda escolha metodológica, um quasi experimento ou experimento natural possui vantagens e desvantagens. Ledgerwood (1999) aponta que uma das vantagens do experimento é a de que é mais fácil se identificar o efeito, e uma das desvantagens é a dificuldade de se criar um grupo de controle sem viés.

Nos experimentos naturais, mesmo quando o tratamento é aplicado aleatoriamente, por acaso ou por razões institucionais, em muitos casos isso não é suficiente para proporcionar uma estimativa não enviesada do efeito causal (Sekhon e Titiunik, 2012). Esta é uma limitação importante discutida por estes autores. No entanto, a despeito de suas limitações, o experimento natural tem sido cada vez mais utilizado nas pesquisas em ciências sociais. 
Estudos acerca do efeito de mudanças regulatórias têm utilizado cada vez mais a combinação de experimento natural com estimativas por diferenças em diferenças. Cozarenco e Szafarz (2014), por exemplo, utilizaram essa técnica para discutir as consequências dos limites máximos dos empréstimos que eles consideram um componente-chave na regulação de microfinanças. $\mathrm{O}$ experimento natural foi a abordagem utilizada para analisar a conversão de uma ONG francesa de microcrédito não regulamentada em uma IMF regulamentada. Assim, para estes autores, é possível analisar mudanças regulatórias por meio de experimentos naturais, cujas consequências podem ser exploradas econometricamente por estimativa de diferenças em diferenças.

Isto posto, no intuito de investigar o problema de pesquisa proposto, o presente estudo adotou como estratégia metodológica o quasi experimento ou experimento natural, com suporte da técnica de diferenças em diferenças por considerá-la apropriada para capturar os efeitos das mudanças regulatórias ocorridas no MPO no desempenho financeiro e social das cooperativas que ofertam esse tipo de crédito.

\subsection{Constructos e descrição operacional das variáveis}

A opção por um estudo quasi experimental em cooperativas de crédito pode conferir maior validade interna ao estudo. Libby, Bloomfield e Nelson (2002) propõem uma estrutura teórico-conceitual de relação entre as variáveis de estudo. Com base nessa recomendação, a Figura 16 sintetiza a relação entre as variáveis do presente estudo. Assim, a relação entre as variáveis é explicada com base nos conceitos de desempenho financeiro e social já discutidos e nas Resoluções apresentadas.

\subsubsection{Variáveis dependentes}

As variáveis dependentes são os indicadores de desempenho financeiro e social das cooperativas de crédito. As variáveis representativas do desempenho financeiro estão divididas em três grupos: Qualidade dos Ativos, Eficiência e Rentabilidade. O desempenho social comtempla duas dimensões: a amplitude (breadth) do alcance e a profundidade (depth) do alcance.

\subsubsection{Variáveis independentes}


As variáveis independentes são representadas pelas mudanças regulatórias ocorridas no microcrédito com base na Resolução do $\mathrm{BCB}^{\mathrm{0}}{ }^{-}$4.000/2011 (BCB, 2011) e da criação do Programa CRESCER - Lei n⿳ำ 12.666/2012 (Brasil, 2012). A mensuração destas variáveis se dá com base nas dummies de grupo (de controle e de tratamento) e de tempo (antes e depois do evento), além da interação entre as duas dummies.

Conceitualmente, esses desempenhos foram definidos com base na literatura, em sugestões dos entrevistados e utilização de índices pelo BCB. Operacionalmente, foram mensurados com base nos indicadores financeiros e sociais apresentados na Figura 16.

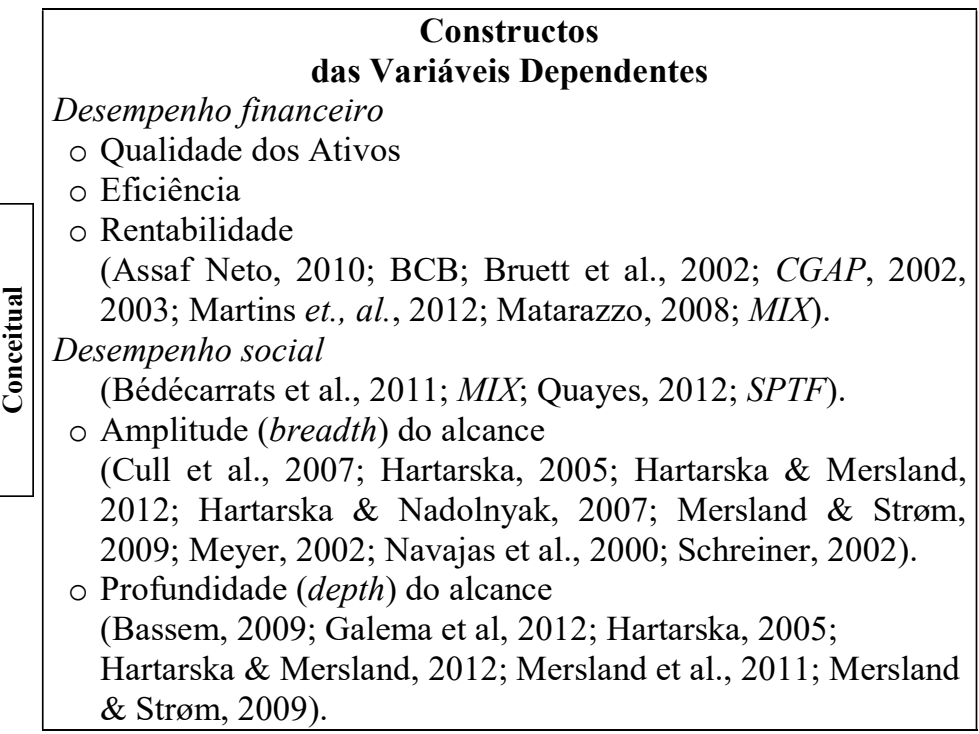

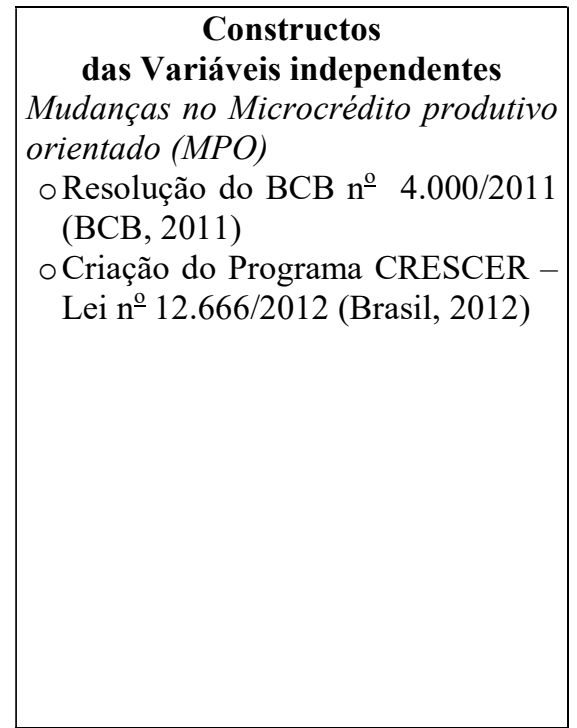

Variáveis Dependentes
Indicadores de desempenho financeiro (MIX, BCB)
o Qualidade dos Ativos
Inadimplência
Taxa de inadimplência
Rentabilidade da carteira de crédito
Rendas de juros com operações de crédito em relação ao ativo
total ajustado
Margem de intermediação financeira (semestral)
Resultado da intermediação financeira
Resultado da intermediação financeira (somente juros)
o Rentabilidade
ROA - Retorno sobre Ativo (anual)
ROE - Retorno sobre o Patrimônio Líquido (semestral)
o Eficiência
Margem operacional (semestral
Custo operacional
Indicadores de Desempenho social (MIX e Quayes, 2012)
o Amplitude (breadth) do alcance
Total de clientes
Total de operações
Profundidade (depth) do alcance
Valor médio das operações
Carteira ativa média

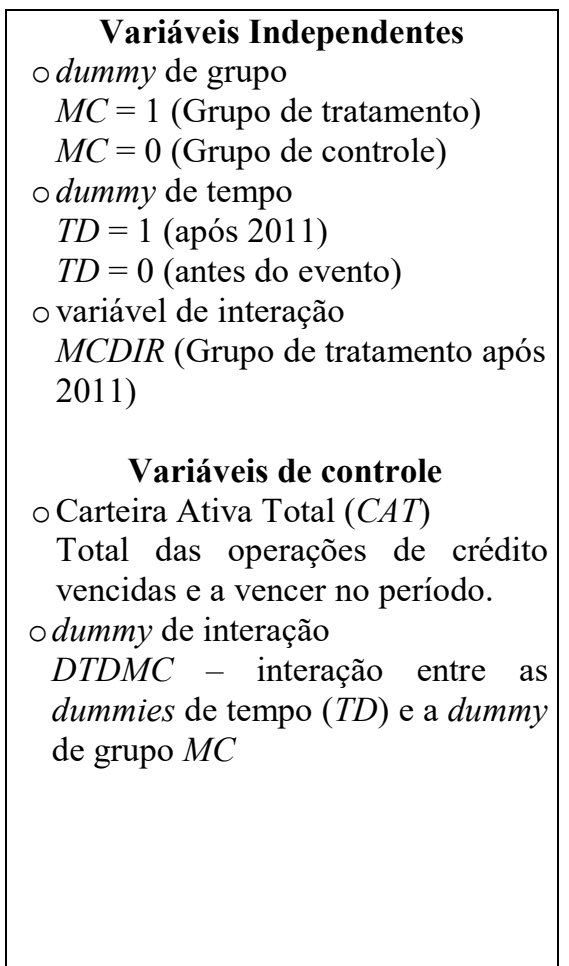

Figura 16: Estrutura conceitual e operacional da relação entre as variáveis do estudo.

Fonte: Adaptado de Libby, Bloomfield e Nelson (2002). 
Com base na revisão de literatura, em algumas sugestões apontadas pelos agentes qualificados entrevistados, e considerando ainda os objetivos deste estudo, foram definidas como variáveis a serem testadas, as especificadas na Tabela 2. A fundamentação teórica dos indicadores de desempenho financeiro e social é apresentada no Capítulo II.

Tabela 2: Variáveis de mensuração de desempenho financeiro e social

\begin{tabular}{|c|c|c|c|}
\hline Grupo & Sigla & Indicador & Método de cálculo \\
\hline \multicolumn{4}{|l|}{$\begin{array}{l}\text { Indicadores } \\
\text { Financeiros }\end{array}$} \\
\hline \multirow[t]{11}{*}{ Qualidade dos Ativos } & INAD & $\begin{array}{l}\text { Inadimplência - Carteira } \\
\text { em Risco }>90 \text { dias }\end{array}$ & $\begin{array}{l}\text { Saldo de empréstimos atrasados }> \\
90 \text { dias }\end{array}$ \\
\hline & \multirow[t]{2}{*}{ TX_INAD } & \multirow[t]{2}{*}{ Taxa de inadimplência } & $\begin{array}{l}\text { Saldo de empréstimos atrasados }> \\
90 \text { dias }\end{array}$ \\
\hline & & & Carteira ativa total \\
\hline & \multirow[t]{2}{*}{ RENT_CART } & \multirow{2}{*}{$\begin{array}{l}\text { Rentabilidade da carteira } \\
\text { de crédito }\end{array}$} & Rendas de operações de crédito \\
\hline & & & Carteira de crédito classificada \\
\hline & \multirow[t]{2}{*}{ REND_JR } & \multirow{2}{*}{$\begin{array}{l}\text { Rendas de juros com } \\
\text { operações de crédito em } \\
\text { relação ao ativo total } \\
\text { ajustado }\end{array}$} & $\begin{array}{l}\text { Rendas de juros com operações de } \\
\text { crédito }\end{array}$ \\
\hline & & & Ativo total ajustado (anual) \\
\hline & \multirow[t]{2}{*}{ MARG_FIN } & \multirow[t]{2}{*}{$\begin{array}{l}\text { Margem de intermediação } \\
\text { financeira }^{2} \text { (semestral) }\end{array}$} & $\begin{array}{l}\text { Resultado da intermed. financeira } \\
\text { semestral }\end{array}$ \\
\hline & & & Receita operacional semestral \\
\hline & RESULT_FIN & $\begin{array}{l}\text { Resultado da } \\
\text { intermediação financeira }\end{array}$ & $\begin{array}{l}\text { Receitas da intermediação financeira - } \\
\text { despesas da intermediação financeira }\end{array}$ \\
\hline & RESULT_FIN_J & $\begin{array}{l}\text { Resultado da } \\
\text { intermediação financeira } \\
\text { (somente juros) }\end{array}$ & $\begin{array}{c}\text { Receitas da intermediação financeira - } \\
\text { despesas da intermediação financeira } \\
\text { (considerando apenas o resultados de } \\
\text { juros) }\end{array}$ \\
\hline \multirow[t]{4}{*}{ Rentabilidade } & \multirow[t]{2}{*}{ ROA } & \multirow[t]{2}{*}{$\begin{array}{l}\text { ROA-Retorno sobre } \\
\text { Ativo (anual) }\end{array}$} & $\begin{array}{l}\text { Resultado operacional líquido, } \\
\text { ajustado - Impostos }\end{array}$ \\
\hline & & & Ativo total médio ajustado \\
\hline & \multirow[t]{2}{*}{ ROE } & \multirow{2}{*}{$\begin{array}{l}R O E^{3} \text { - Retorno sobre o } \\
\text { Patrimônio Líquido } \\
\text { (semestral) }\end{array}$} & $\begin{array}{c}\text { Resultado operacional líquido, } \\
\text { ajustado - Impostos }\end{array}$ \\
\hline & & & $\begin{array}{l}\text { Patrimônio líquido médio ajustado } \\
\text { do semestre }\end{array}$ \\
\hline \multirow[t]{4}{*}{ Eficiência } & \multirow[t]{2}{*}{ MARG_OP } & \multirow{2}{*}{$\begin{array}{l}\text { Margem operacional } \\
\text { (semestral) }\end{array}$} & Resultado operacional semestral \\
\hline & & & Receita operacional semestral \\
\hline & \multirow[t]{2}{*}{ CUST_OP } & \multirow[t]{2}{*}{ Custo operacional } & Despesas administrativas \\
\hline & & & $\begin{array}{l}\text { (Resultado de intermediação } \\
\text { financeira + receita de serviços) }\end{array}$ \\
\hline \multicolumn{4}{|l|}{ Indicadores Sociais } \\
\hline Amplitude do alcance & CLIEN & Total de clientes & $\begin{array}{l}\text { Quantidade de clientes ativos no } \\
\text { semestre por modalidades: } 1,2,3,4 \mathrm{e} \\
\text { submodalidades } 1303 \text { e 1304, } 212 \text { - } \\
\text { empréstimos (microcrédito consumo) e } \\
403 \text { - financiamentos (microcrédito } \\
\text { produtivo). }\end{array}$ \\
\hline
\end{tabular}




\begin{tabular}{|c|c|c|c|}
\hline Grupo & Sigla & Indicador & Método de cálculo \\
\hline \multirow{5}{*}{$\begin{array}{l}\text { Profundidade do } \\
\text { alcance }\end{array}$} & OPER & Total de operações & $\begin{array}{l}\text { Quantidade de operações realizadas no } \\
\text { semestre por modalidades: } 1,2,3,4 \text { e } \\
\text { submodalidades } 1303 \text { e 1304, } 212 \text { - } \\
\text { empréstimos (microcrédito consumo) e } \\
403 \text { - financiamentos (microcrédito } \\
\text { produtivo). }\end{array}$ \\
\hline & \multirow[t]{2}{*}{ ME_OPER } & \multirow[t]{2}{*}{$\begin{array}{l}\text { Valor médio das } \\
\text { operações }\end{array}$} & $\begin{array}{c}\text { Total de operações realizadas no } \\
\text { semestre }\end{array}$ \\
\hline & & & Total de clientes ativos no semestre \\
\hline & \multirow[t]{2}{*}{ ME_CA } & \multirow[t]{2}{*}{ Carteira ativa média ${ }^{4}$} & Total da carteira ativa no semestre \\
\hline & & & $\begin{array}{l}\text { Quantidade de operações no } \\
\text { semestre }\end{array}$ \\
\hline
\end{tabular}

Fontes: BCB, $M I X$ e Quayes (2012).

\subsection{Protocolo da coleta de dados}

\subsubsection{Fontes dos dados}

No intuito de atender ao objetivo desta pesquisa, fez-se, inicialmente, uma pesquisa documental, quando foram analisadas as leis e resoluções desde a criação do PNMPO, em 2005, e as mudanças ocorridas até 2014.

As informações contábeis das instituições financeiras no Brasil são elaboradas com base no sistema COSIF - plano de contas criado e adotado com o objetivo de unificar a contabilização por estas instituições e facilitar o trabalho de regulamentação e fiscalização realizado pelo BCB. Os dados coletados pertencem ao nível $5^{18}$ do plano de contas do COSIF, ou seja, são contas analíticas, usadas para efeito de controle e físcalização pelo BCB e, portanto, essas informações estão protegidas com base na lei do sigilo bancário.

Buscando melhorar a discussão dos dados e compreender melhor outras questões não respondidas pelos dados até então, realizou-se concomitantemente à coleta de dados no BCB algumas entrevistas semiestruturadas - com roteiro previamente estabelecido - nos tipos de instituições habilitadas pelo MTE. As entrevistas foram feitas com informantes qualificados, com conhecimento prático e teórico sobre MPO. O objetivo foi identificar, sob a ótica de quem opera e/ou administra as operações de microcrédito, questões como quais os pontos fortes e fracos na execução do PNMPO/CRESCER, os entraves e sugestões de melhorias que poderiam ser implementadas ao Programa, além de questões relacionadas à operação

\footnotetext{
${ }^{18}$ Os relatórios financeiros elaborados de acordo com o Plano Contábil das Instituições do Sistema Financeiro Nacional - COSIF possuem cinco níveis de detalhamento. O documento que é remetido ao BCB apresenta nível 5 , ou até "título contábil/subtítulo contábil". O documento que é publicado na imprensa apresenta nível 3 , ou até o desdobramento de subgrupo (www.bcb.gov.br).
} 
propriamente dita (custo, taxas de juros, metodologia utilizada etc.). Desse modo, foram entrevistados agentes de cada tipo de instituição habilitada no MTE: OSCIPs, bancos públicos, bancos privados, agências de fomento, cooperativas de crédito, com exceção das SCMs, nas quais, a despeito de diversas tentativas, não foi possível entrevistar um agente com experiência no assunto.

Algumas entrevistas foram realizadas pessoalmente e outras via internet (Skype e email) durante o período de 25 de junho de 2015 a 12 de agosto de 2015. Inicialmente, decidiuse entrevistar um agente por cada tipo de instituição. Ocorre que nem todos os entrevistados tinham todas as informações buscadas, então, em alguns casos o número de entrevistados foi ampliado para dois ou três por tipo de instituição. As entrevistas foram realizadas dentro dos preceitos éticos adotados pelo Comitê de Ética em Pesquisa da Universidade Estadual de Feira de Santana (UEFS), gravadas com a devida autorização dos entrevistados e, em seguida, transcritas. Todos os participantes foram informados antecipadamente sobre os objetivos da pesquisa e, espontaneamente, assinaram o "Termo de Consentimento Livre e Esclarecido" (TCLE) autorizando, assim, o uso das informações na pesquisa.

No total, foram realizadas sete entrevistas com profundidade, as quais duraram, em média, 60 minutos assim distribuídas: Bancos públicos - dois agentes de crédito e um exsuperintendente; OSCIPs - um diretor; Cooperativas de crédito - um coordenador de microcrédito; Agências de fomento: um supervisor dos programas de microcrédito; Bancos privados - um superintendente de microcrédito.

As entrevistas viabilizaram um maior aprofundamento do assunto na fase exploratório-descritiva e também deram subsídios para melhorar a análise na medida em que trouxeram informações complementares às obtidas nas bases de dados do MTE e do BCB. Isto permitiu ampliar o volume de informações e, consequentemente, o aprofundamento das análises. As respostas dos entrevistados também ajudaram na escolha e construção dos indicadores de desempenho escolhidos para o estudo.

No entanto, não foi possível a realização de uma grande quantidade de entrevistas. Em primeiro lugar, porque são poucos os agentes com conhecimento teórico e prático consolidado sobre microcrédito. O segundo motivo é que, como muitas perguntas referiam-se a um programa público e outras sobre especificidades das operações, os informantes não tinham autorização das respectivas instituições que representam para o fornecimento dos dados. Tampouco foi autorizado por parte deles a divulgação dos seus nomes e dos nomes das respectivas instituições. Estas restrições estão em linha com os princípios éticos da privacidade e garantia de anonimato previstas na legislação sobre ética na pesquisa no país, 
razão pela qual não há qualquer menção que possa identificar os(as) respondentes ou associálos às respectivas instituições que representam.

De forma resumida, a base de dados foi construída com base nas seguintes fontes:

- MTE - quantitativo de contratos, que permitiu observar o efeito mais imediato das mudanças regulatórias;

- Banco Central do Brasil, cujos dados foram extraídos de três fontes distintas: o SCR, COSIF e dados de fiscalização;

- Entrevistas semiestruturadas com pessoas qualificadas de bancos públicos, bancos privados, agências de fomento, OSCIPs e cooperativas de crédito. Não houve entrevista com agentes de SCM.

Assim, de posse dos dados, partiu-se para os testes estatísticos e posterior análise.

\subsubsection{População da pesquisa}

As mudanças regulatórias ocorridas no PNMPO e a implantação do Programa CRESCER foram mandatórias para os bancos públicos federais. Para as demais instituições financeiras foram opcionais. Inicialmente, pensou-se em analisar os efeitos dessas mudanças nos bancos públicos, os quais foram afetados mais diretamente. Ocorre que, nesse tipo de instituição, a carteira de microcrédito é pouco representativa em relação ao total de operações e seria difícil capturar qualquer efeito por meio de indicadores de desempenho. Com os bancos privados ocorre o mesmo, e além disso, ainda são poucos os que operam o microcrédito, sobretudo o produtivo orientado. Ademais, neste tipo de instituição também seria mais difícil encontrar um grupo de comparação adequado para que se pudesse identificar o efeito das mudanças regulatórias. Isto é, seria mais difícil um teste utilizando a técnica diferenças em diferenças. As SCMs, do mesmo modo, são pouco representativas tanto em termos de volume de recursos quanto em quantidade de operações. Em relação às agências de fomento, uma análise de desempenho não se mostrou relevante e viável, porque a maioria delas atuam como intermediárias, ou seja, repassando recursos para OSCIPs e cooperativas de crédito.

Outro motivo que levou à escolha das cooperativas de crédito, como já dito anteriormente, foi a análise exploratória dos dados disponibilizados pelo Ministério do Trabalho e Emprego (MTE). Essa análise possibilitou uma percepção ampla e geral a respeito do efeito mais imediato das mudanças regulatórias estudadas, um vez que foi possível 
observar as tendências de crescimento da oferta de microcrédito em todos os tipos de instituições que operam o MPO.

A análise dos dados do MTE evidenciou que, dentre as instituições concedentes de microcrédito, as cooperativas de crédito foram as que tiveram uma taxa de crescimento da oferta com comportamento semelhante à dos bancos públicos - grupo mais diretamente afetado pelas mudanças regulatórias - , ainda que em magnitude consideravelmente menor.

As cooperativas de crédito são instituições financeiras bastante representativas no Sistema Financeiro Brasileiro em termos de quantidade, como mostra a Tabela 3.

Tabela 3: Evolução do quantitativo de instituições financeiras autorizadas ${ }^{3}$ pelo BCB, por segmento - 2008 a 2014

\begin{tabular}{|c|c|c|c|c|c|c|c|}
\hline Segmento & 2008 & 2009 & 2010 & 2011 & 2012 & 2013 & 2014 \\
\hline Banco Múltiplo & 140 & 139 & 139 & 139 & 138 & 132 & 130 \\
\hline Banco Comercial $^{1}$ & 18 & 18 & 20 & 21 & 23 & 23 & 22 \\
\hline Banco de Desenvolvimento & 4 & 4 & 4 & 4 & 4 & 4 & 4 \\
\hline Caixa Econômica Federal & 1 & 1 & 1 & 1 & 1 & 1 & 1 \\
\hline Banco de Investimento & 17 & 16 & 15 & 14 & 14 & 14 & 14 \\
\hline Banco de Câmbio & - & - & 2 & 2 & 2 & 3 & 3 \\
\hline Sociedade de Crédito, Financiamento e Investimento & 55 & 59 & 61 & 60 & 59 & 58 & 55 \\
\hline \multicolumn{8}{|l|}{ Sociedade Corretora de Títulos e Valores } \\
\hline Mobiliários & 107 & 105 & 107 & 100 & 95 & 93 & 92 \\
\hline Sociedade Corretora de Câmbio & 45 & 45 & 44 & 49 & 57 & 62 & 66 \\
\hline \multicolumn{8}{|l|}{ Sociedade Distribuidora de Títulos e Valores } \\
\hline Mobiliários & 135 & 125 & 127 & 127 & 118 & 116 & 108 \\
\hline \multirow{2}{*}{$\begin{array}{l}\text { Sociedade de Arrendamento Mercantil } \\
\text { Sociedade de Crédito Imobiliário }{ }^{2} \text { e Associação de }\end{array}$} & 36 & 33 & 33 & 31 & 30 & 29 & 27 \\
\hline & & & & & & & \\
\hline \multirow{2}{*}{$\begin{array}{l}\text { Poupança e Empréstimo } \\
\text { Sociedade de Crédito ao Microempreendedor e à }\end{array}$} & 16 & 16 & 14 & 14 & 12 & 11 & 9 \\
\hline & & & & & & & \\
\hline Empresa de Pequeno Porte & 47 & 45 & 45 & 42 & 40 & 38 & 40 \\
\hline Agência de Fomento & 12 & 14 & 15 & 16 & 16 & 16 & 16 \\
\hline Companhia Hipotecária & 6 & 6 & 7 & 8 & 7 & 8 & 7 \\
\hline \multirow[b]{2}{*}{ Cooperativa de Crédito } & & & 634 & 628 & 616 & 608 & 594 \\
\hline & 1.453 & 1.405 & 1.377 & 1.328 & 1.269 & 1.209 & 1163 \\
\hline Subtotal & & & 2.011 & 1.956 & 1.885 & 1.817 & 1.757 \\
\hline \multirow[t]{2}{*}{ Sociedade Administradora de Consórcio } & 317 & 308 & 301 & 284 & 222 & 199 & 186 \\
\hline & Total & & 2.312 & 2.240 & 2.107 & 2.016 & 1.943 \\
\hline
\end{tabular}

Fonte: Unicad.

Diretoria de Organização do Sistema Financeiro e Controle de Operações do Crédito Rural - Diorf - BCB.

Departamento de Organização do Sistema Financeiro - Deorf - BCB.

1. Inclui os bancos estrangeiros (filiais no país)

${ }^{2}$. Inclui sociedades de crédito imobiliário (Repassadoras / SCIR) que não podem captar recursos junto ao público.

${ }^{3}$ Foram consideradas as instituições nas seguintes situações: "Autorizadas sem Atividade"; "Autorizadas em Atividade; "Em Adm. Especial Temporária"; "Em Intervenção" e "Paralisadas”.

A quantidade de cooperativas é consideravelmente superior quando comparada com a quantidade das demais instituições financeiras, como evidencia a Tabela 3.

A Tabela 4 mostra a participação percentual das cooperativas no sistema financeiro nacional, comparativamente às demais instituições financeiras, de 2010 a 2014. Apesar de 
pequena a sua participação (1,75\% em 2014), ela cresceu ao longo do período em $36,71 \%$. Os bancos múltiplos (públicos e privados), de fato, concentram a participação nos ativos totais do sistema financeiro $(91,17 \%$ em 2014).

Tabela 4: Participação percentual dos diversos segmentos do SFN nos ativos totais do sistema - 2010 a 2014

\begin{tabular}{|c|c|c|c|c|c|}
\hline Segmento & 2010 & 2011 & 2012 & 2013 & 2014 \\
\hline Banco Múltiplo & 70,58 & 70,11 & 69,24 & 68,12 & 67,18 \\
\hline Banco Comercial $^{1}$ & 0,57 & 0,57 & 0,60 & 0,65 & 0,59 \\
\hline Banco de Desenvolvimento & 9,29 & 9,76 & 10,01 & 10,19 & 10,38 \\
\hline Caixa Econômica Federal & 7,51 & 8,10 & 9,94 & 11,20 & 12,37 \\
\hline Banco de Investimento & 0,92 & 0,86 & 0,91 & 0,76 & 0,65 \\
\hline Banco de Câmbio & 0,0001 & 0,001 & 0,002 & 0,003 & 0,003 \\
\hline Sociedade de Crédito, Financiamento e Investimento & 1,88 & 1,93 & 1,79 & 1,76 & 1,53 \\
\hline Sociedade Corretora de Títulos e Valores Mobiliários e & & & & & \\
\hline Corretora de Câmbio & 0,44 & 0,34 & 0,33 & 0,35 & 0,34 \\
\hline Sociedade Distribuidora de Títulos e Valores & & & & & \\
\hline Mobiliários & 0,25 & 0,18 & 0,15 & 0,14 & 0,15 \\
\hline Sociedade de Arrendamento Mercantil & 7,08 & 6,54 & 5,32 & 4,97 & 4,82 \\
\hline $\begin{array}{l}\text { Sociedade de Crédito Imobiliário e Associação de } \\
\text { Poupança e Empréstimo }\end{array}$ & 0,06 & 0,08 & 0,08 & 0,08 & 0,07 \\
\hline Sociedade de Crédito ao Microempreendedor e à & & & & & \\
\hline Empresa de Pequeno Porte & 0,002 & 0,002 & 0,002 & 0,002 & 0,003 \\
\hline Agência de Fomento & 0,12 & 0,11 & 0,11 & 0,13 & 0,12 \\
\hline Companhia Hipotecária & 0,02 & 0,03 & 0,03 & 0,03 & 0,02 \\
\hline Cooperativa de Crédito & 1,28 & 1,37 & 1,46 & 1,62 & 1,75 \\
\hline Total & 100 & 100 & 100 & 100 & 100 \\
\hline
\end{tabular}

Fonte: COSIF - transação PCOS200 (doc. 4016), BCB.

Diretoria de Organização do Sistema Financeiro e Controle de Operações do Credito Rural - Diorf.

Departamento de Organização do Sistema Financeiro - Deorf.

${ }^{1}$ Inclui Filial de Banco Estrangeiro (BCE-FP).

O segmento cooperativas também teve incremento substancial no tocante à sua participação no SFN em termos de patrimônio líquido, total de ativos, depósitos e operações de crédito como pode ser observado na tabela 5. Por outro lado, a informação da evolução em termos percentuais encontra-se na tabela 4.

No que se refere especificamente às operações de crédito, de 2011 a 2013, anos de implementação das medidas estudadas, a evolução foi maior (taxa de crescimento entre 2011 e 2013 de 59,67\%) do que no período posterior (17,8\% após 2013).

Tabela 5: Evolução do Patrimônio Líquido, Ativos, Depósitos e Operações de Créditol das Cooperativas de Crédito - 2010 a 2014 - em R\$ bilhões

\begin{tabular}{lccccc}
\hline \multicolumn{1}{c}{ Agregados Patrimoniais } & 2010 & 2011 & 2012 & 2013 & 2014 \\
\hline Patrimônio Líquido & 13,10 & 15,9 & 19,3 & 22,8 & 27,4 \\
Ativos & 68,6 & 86,3 & 103,5 & 124,3 & 150,9 \\
Depósitos & 30,1 & 38,1 & 46,9 & 56,3 & 68,5 \\
Operações de Crédito & 28,6 & 36,2 & 45,5 & 57,8 & 68,0 \\
\hline
\end{tabular}

Fonte: COSIF, BCB.

${ }^{1}$ Até 2012, valores relativos a patrimônio líquido, depósitos, operações de crédito e ativos referem-se, respectivamente, às contas COSIF 61000001; 41000007; 16000001 e à diferença entre as contas 39999993 e 30000001 . 
Essa representatividade é mais uma razão que justifica a escolha das cooperativas de crédito como laboratório para o presente estudo. Adicionalmente, as cooperativas trabalham exclusivamente com crédito, o que facilita as análises, uma vez que para elas o microcrédito é mais representativo e significativo em relação ao total de operações (vide Figura 18), o que não ocorre com os bancos públicos, por exemplo, cuja carteira de microcrédito representa pouco em relação à quantidade e variedade de produtos e serviços oferecidos.

De acordo com Banco Central do Brasil (BCB, 2015), o microcrédito ainda é pouco significativo no Brasil, representando $0,2 \%$ do valor e $0,4 \%$ das operações do Sistema Financeiro Nacional (SFN) como um todo. A Figura 17 mostra a evolução da participação relativa do microcrédito em relação ao SFN, a qual, com base nos dados e na definição de microcrédito do BCB (2015), não sofreu variação entre o final de 2007 e o final de 2014.

Dezembro de 2007

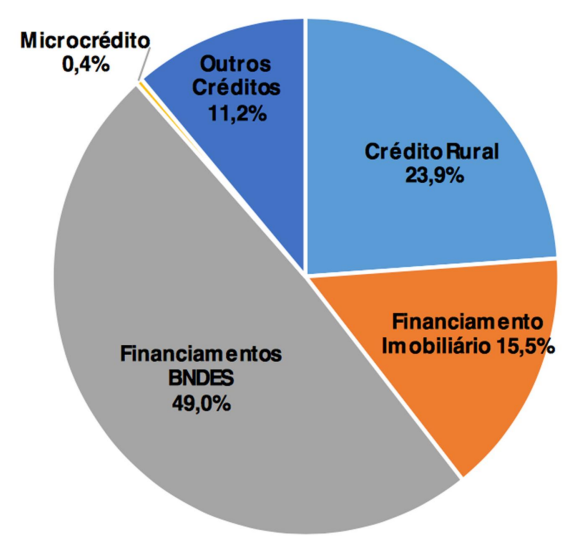

Dezembro de 2014

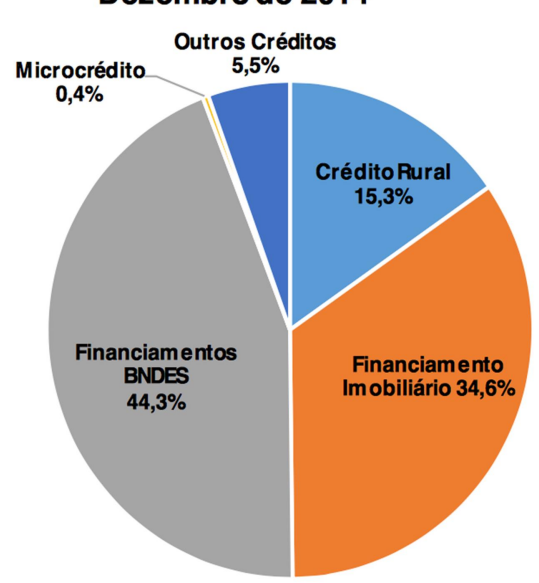

Figura 17: Participação relativa por linhas de crédito dos recursos direcionados, em \% - dez/2007 a de/2014 Fonte: BCB (2015).

No segmento das cooperativas, o microcrédito ocupa a terceira posição representando $13,51 \%$ frente às demais submodalidades, conforme pode ser visualizado na Figura 18. 


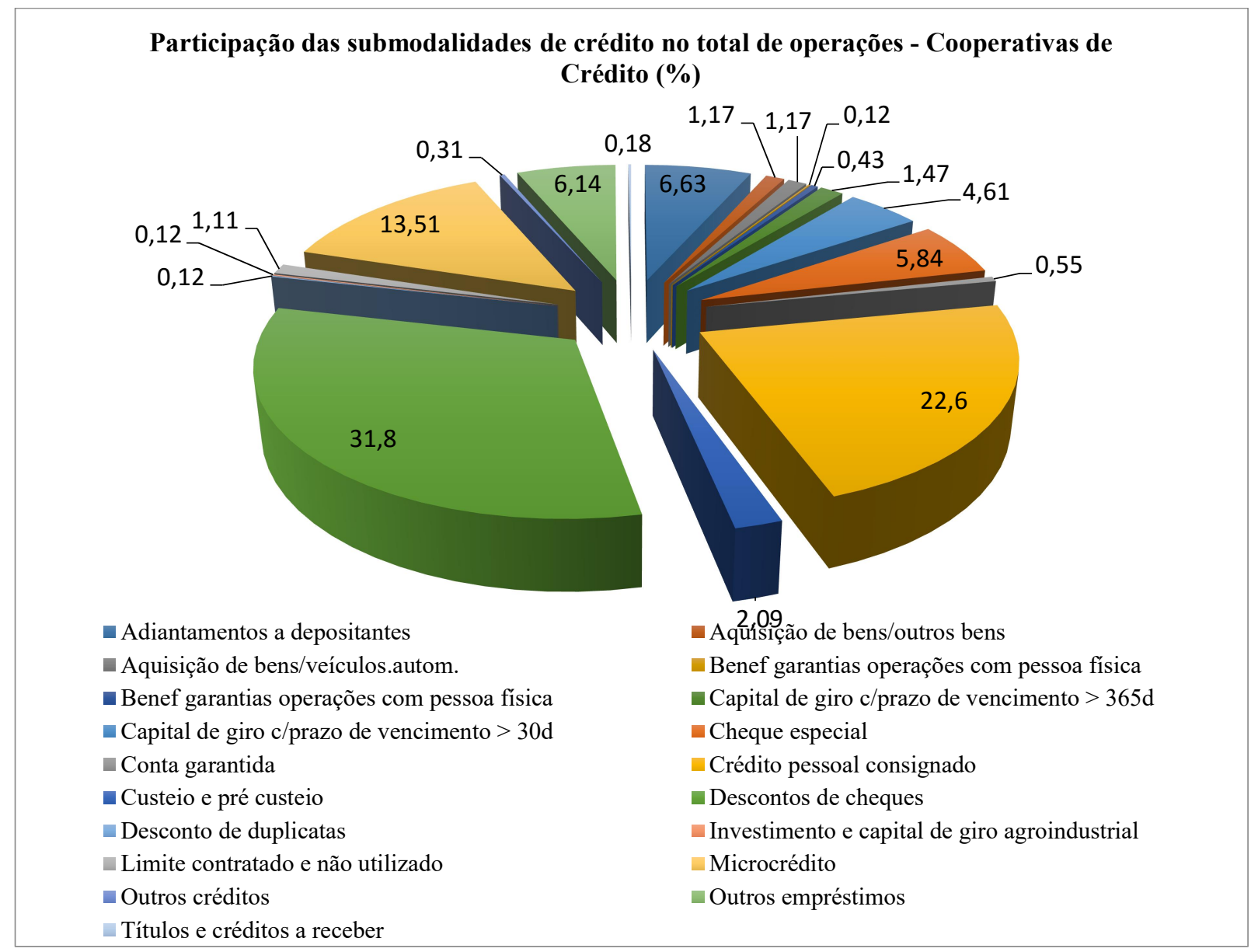

Figura 18: Participação das submodalidades de crédito no total de operações - Cooperativas de Crédito (\%) Fonte: BCB (2015).

Em relação à quantidade de instituições financeiras que ofertam microcrédito, ainda conforme o BCB (2005), o maior número é o das cooperativas de crédito, conforme Figura 19.

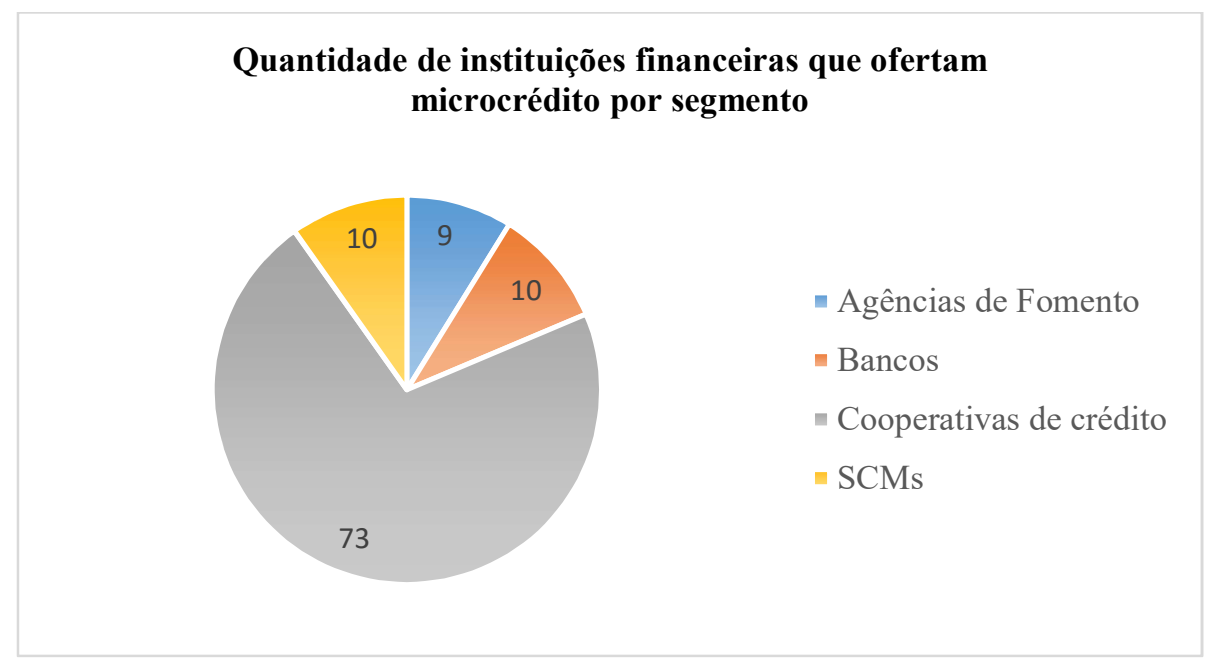

Figura 19: Quantidade de instituições financeiras que ofertam microcrédito por segmento.

Fonte: BCB (2015). 
Quanto à participação percentual de cada tipo de IMF na carteira de microcrédito, os bancos concentram mais de $90 \%$ do valor e as cooperativas figuram em segundo lugar, com $6,1 \%$ de participação, conforme Figura 20.

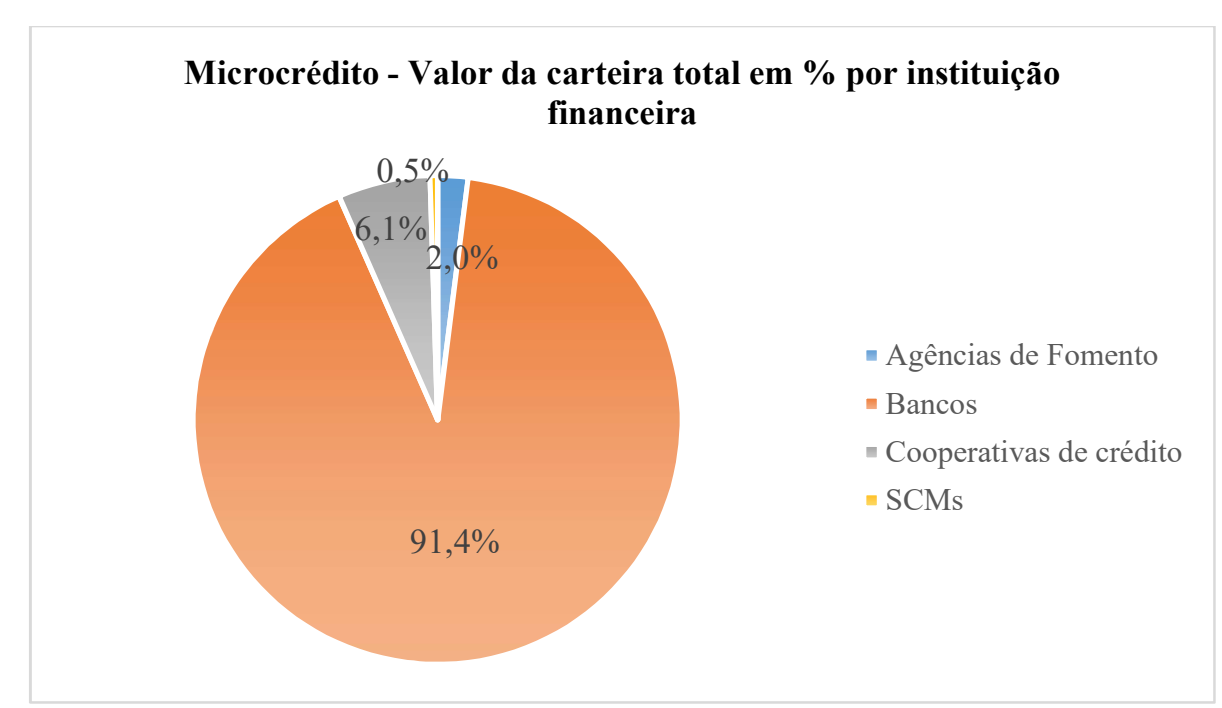

Figura 20: Microcrédito - Valor da carteira total em \% por instituição financeira.

Fonte: BCB (2015).

\subsubsection{Observações a respeito das diferenças metodológicas e conceituais das bases de} dados utilizadas

Inicialmente, tentou-se comparar as bases do MTE e do BCB, porém isto não foi possível em razão das diferenças metodológicas.

As diferenças metodológicas e conceituais entre as bases SCR, COSIF e MTE começam pelo próprio conceito de microcrédito nelas adotado. Essas diferenças levam a divergências entre os dados, desde os quantitativos de clientes, de operações e até mesmo a quantidade de instituições que ofertam MPO.

Microcrédito produtivo orientado, de acordo com o MTE, é a concessão de crédito destinado a atividades produtivas de pequeno porte, desenvolvidas por pessoas físicas e jurídicas, formais e informais, com renda bruta anual de até 120 mil. Para tal, é utilizada uma metodologia própria (acompanhamento de agente de crédito capacitado para tal). De acordo com dados do MTE divulgados em relatórios trimestrais, a distribuição das instituições habilitadas ao programa são as constantes na Tabela 6. 
Tabela 6: Evolução do quantitativo de instituições habilitadas pelo MTE a operar no âmbito do PNMPO (20052015)

\begin{tabular}{|c|c|c|c|c|c|c|c|c|c|c|c|}
\hline IMF & 2005 & 2006 & 2007 & 2008 & 2009 & 2010 & 2011 & 2012 & 2013 & $2014^{1}$ & $2015^{2}$ \\
\hline OSCIPs & 40 & 90 & 103 & 124 & 129 & 135 & 144 & 144 & NI & 160 & 164 \\
\hline SCMs & 10 & 16 & 16 & 16 & 19 & 22 & 25 & 25 & NI & 25 & 26 \\
\hline IFOs & 0 & 3 & 3 & 3 & & 5 & 8 & 8 & NI & 12 & 12 \\
\hline Cooperativas de crédito & 0 & 100 & 120 & 125 & 127 & 147 & 168 & 168 & NI & 290 & 292 \\
\hline Agências de fomento (AF) & 2 & 4 & 5 & 5 & 7 & 8 & 10 & 10 & NI & 10 & 10 \\
\hline Cooperativas centrais de crédito & 0 & 2 & 4 & 4 & & 4 & 4 & 4 & NI & 7 & 7 \\
\hline Bancos cooperativos & 0 & 1 & 1 & 1 & 1 & 1 & 1 & 1 & NI & 1 & 1 \\
\hline Bancos de desenvolvimento & & & & & & 2 & 2 & 2 & NI & 4 & 4 \\
\hline Sociedades operadoras de MPO & & & & & & & & & $\mathrm{NI}$ & 2 & 2 \\
\hline Total & 52 & 216 & 252 & 278 & 283 & 324 & 362 & 362 & $\mathrm{NI}$ & 511 & 522 \\
\hline
\end{tabular}

Fonte: Elaboração própria com base nos Relatórios do PNMPO, MTE.

${ }^{1}$ Data de Referência: 09/12/2014

${ }^{2}$ Data de Referência: 08/06/2015

Para o BCB, a definição de microcrédito é mais restrita e vem sofrendo modificações. O SCR considera como microcrédito exclusivamente as operações que seguem a Resolução $\mathrm{BCB} \mathrm{n}^{\mathrm{o}}$ 4.152/2012 (BCB, 2012): concessão de crédito a microempreendedores (formais ou informais) com uso, pela instituição concedente, de uma metodologia específica de relacionamento com o cliente aplicada por equipe especializada (Banco Central do Brasil [BCB], 2014).

Para efeito de registro no SCR, o microcrédito divide-se em duas modalidades: empréstimo (código 0212) - que seria equivalente ao microcrédito de consumo -, e financiamento (código 0403) - correspondente ao microcrédito produtivo. O histórico de dados desta última modalidade teve início em 2003, mas a modalidade empréstimo é mais recente, tendo sido introduzida somente em setembro de 2012, a partir da Resolução $\mathrm{n}^{\mathrm{o}}$ 4.152/2012 (BCB, 2012). Segundo o BCB (2015), até então não havia uma definição de microcrédito explicitada no âmbito do SCR.

Além da incipiência na oferta de microcrédito por todos os tipos de instituições no Brasil, o estudo do BCB (2015) também constatou uma forte concentração nesta oferta em âmbito nacional. Dentre os bancos concedentes, em 2013, quatro concentravam $94,8 \%$ da carteira e 92,4\% das operações; em relação às agências de fomento, três respondiam por $97,8 \%$ da carteira e $91,3 \%$ das operações; entre as SCMs, duas delas operavam $96,1 \%$ da carteira e 98,2\% das operações e; no que tange às cooperativas, quatro delas respondiam por $81,6 \%$ da carteira e 84,9\% das operações (BCB, 2015). Em síntese, em 2013, último ano para o cumprimento das metas do CRESCER pelos bancos públicos, o referido estudo constatou que quase $90 \%$ da oferta total de microcrédito era realizada pelos quatro bancos públicos. 


\subsection{Definição do grupo de controle}

Um grupo de controle, para ser validado, deve obedecer a três premissas: (1) as características dos grupos de tratamento e de comparação devem ser, em média, as mesmas; (2) os grupos de tratamento e de comparação devem responder ao "tratamento" da mesma maneira; (3) os grupos de tratamento e de controle não podem ser diferencialmente expostos a outras intervenções durante o período de avaliação (Verter et al., 2011). Para os autores, se estas três condições são cumpridas, as diferenças médias nos resultados entre os dois grupos podem ser atribuídas ao "tratamento"/evento. No caso das cooperativas, as duas últimas condições são atendidas e no caso da primeira, a maioria das características das cooperativas, em média, se assemelham muito entre os dois grupos. Entretanto, o tratamento não foi alocado aleatoriamente entre as cooperativas porque elas poderiam escolher trabalhar ou não com microcrédito. Portanto, não é possível assegurar que os grupos de tratamento e controle são perfeitamente comparáveis.

O critério para a seleção do grupo de tratamento foi a cooperativa ter concedido em algum momento do período estudado, a saber, 2008 a 2014, microcrédito nas duas modalidades: empréstimo (consumo) e financiamento (produtivo). A separação destas modalidades não foi possível em razão das questões discutidas acima, isto é, as instituições somente começaram a divulgar de forma separada a partir do segundo semestre de 2012. É importante ressaltar que as cooperativas do grupo de tratamento ofertavam microcrédito antes das mudanças regulatórias e, desse modo, se as próprias mudanças regulatórias afetaram a composição dos grupos isso pode introduzir enviesamento na análise.

As principais semelhanças entre os grupos são: (a) as cooperativas são instituições com mesma natureza jurídica; (b) possuem os mesmos objetivos; (c) ofertam os mesmos tipos de produtos e serviços (crédito), diferenciando-se um pouco somente em relação às modalidades de crédito ofertadas.

A população do presente estudo comporta todas as cooperativas de crédito existentes no Sistema Financeiro Nacional, as quais totalizam 1.429 cooperativas que foram observadas durante 14 semestres (2008 a 2014). Com base na análise da estatística descritiva dos dados foi possível observar os aspectos convergentes, assim como os divergentes entre os grupos.

a) Em relação aos tipos de cooperativas, nos dois grupos os mais comuns são crédito rural, crédito mútuo e cooperativas de livre admissão. No grupo de controle, das 1.294 cooperativas, 68\% são destes três tipos assim distribuídos: crédito rural, com $27 \%$ do total; crédito mútuo, com $21 \%$ e; cooperativas de livre admissão 
localizadas em municípios com até 300 mil habitantes, com $20 \%$. No grupo de tratamento, 72 cooperativas ( $53 \%$ do total) são deste último tipo sendo; $15 \%$ de livre admissão localizadas em municípios com 300 mil a 750 mil habitantes e; $19,14 \%$ de crédito rural.

b) No que se refere à localização, as cooperativas em geral estão concentradas nas regiões mais ricas: Sul e Sudeste, com destaque para os seguintes estados: no grupo de controle, $22 \%$ estão localizadas no estado de Minas Gerais, $15 \%$ no Paraná, $14 \%$ estão em São Paulo, $12 \%$ no Rio Grande do Sul e as demais espalhadas pelos outros estados federativos. No grupo de tratamento, $26 \%$ estão localizadas em Minas Gerais, seguida dos estados do Rio Grande do Sul e Santa Catarina, com $22 \%$ e $20 \%$, respectivamente.

c) No que tange às modalidades de crédito ofertadas, no grupo de controle 40,93\% são de empréstimos, $12,60 \%$ são financiamentos rurais, agroindustriais e 12,51\% são de títulos descontados e 10,76\% são financiamentos; no grupo de tratamento, a maioria (32,16\%) também é de empréstimos, seguido das modalidades financiamentos rurais e agroindustriais, financiamentos e títulos descontados, com $16,30 \%, 14,67 \%$ e 13,50\%, respectivamente. A diferença é que aqui a submodalidade microcrédito compõe os empréstimos (submodalidade 0202) e financiamentos (submodalidade 0403).

d) No que concerne à origem dos recursos, no grupo de controle $87,44 \%$ são recursos livres contra $12,56 \%$ de decursos direcionados, enquanto no grupo de tratamento os recursos livres representam $82,19 \%$.

Considerando essas similaridades e assumindo que os grupos de cooperativas tiveram uma trajetória comum durante o período analisado (pressuposto das tendências paralelas), os grupos podem ser comparados. Mesmo os grupos sendo heterogêneos se houver homogeneidade na tendência dos grupos, eles são comparáveis (Angras \& Pischke, 2008; Wooldridge, 2010). Se o pressuposto das tendências paralelas se confirmar, é possível capturar o efeito das mudanças regulatórias do microcrédito no desempenho financeiro e social das cooperativas de crédito, ainda que estas tenham sido afetadas indiretamente, pois dentro das premissas do estimador por Diferenças em Diferenças (Did.), em verdade, não faz diferença se o efeito é direto ou indireto (Angras \& Pischke, 2008; Wooldridge, 2010). As mudanças regulatórias de que trata esta pesquisa, especialmente a redução das taxas de juros e da Taxa de Abertura de Crédito (TAC) e a criação de subsídios para equalização das taxas de quem aderir ao Programa Crescer, são analisadas em conjunto não sendo possível diferenciar 
os efeitos de cada medida indivualmente uma vez que o método Did. não permite distinguir o canal que está gerando o eventual efeito. Caso o pressuposto das tendências paralelas não se confirme, fazem-se necessários alguns controles.

\subsection{Especificação do modelo de análise}

O método de estimação das diferenças estatísticas entre os dois grupos, foi então, um modelo de regressão com dados em painel desbalanceado com 14 períodos de tempo e 1.429 cooperativas de crédito por semestre, com efeito fixo e com o suporte da técnica de diferenças em diferenças. Esta estratégia consiste basicamente em emular um experimento usando dados observacionais. Dados observacionais são dados não experimentais, ou seja, não produzidos por um estudo aleatório e controlado, de modo que a condição ceteris paribus não é assegurada. O estimador do modelo de diferenças em diferenças é o Mínimos Quadrados Ordinário $(M Q O)$ ou OLS (Ordinary Least Squares).

Um pressuposto importante da referida técnica é a existência de tendências comuns ou paralelas entre os grupos de controle e de tratamento no período anterior ao tratamento. Angras e Pischke (2008) afirmam que essa conjectura pode ser investigada pelo uso de dados em painel, usando informações de vários períodos.

A análise de dados em painel é muito utilizada nas estimações de experimentos naturais. Segundo Wooldridge (2010), regressões com dados em painel permitem estimar de forma consistente os efeitos do tratamento em um experimento natural, mesmo sem o uso de variável instrumental, desde que o tratamento varie ao longo do tempo e não esteja correlacionado com variáveis não observáveis que afetam a resposta.

Apesar de amplamente utilizada em estudos que combinam a técnica de diferenças em diferenças, Wooldridge (2010) chama a atenção para a relevância do uso de alguns controles e de, pelo menos, dois períodos de tempo. O presente estudo utilizou seis períodos de tempo antes do evento e seis depois, tendo em vista que o período estudado foi de 2008 a 2014, com dados semestrais.

O modelo básico utilizado no presente estudo pode ser representado pela Equação 1.

$y_{i t}=\beta_{0}+\beta_{1} D I R_{t}+\beta_{2} M C_{i}+\beta_{3}(M C \times D I R)_{i t}+L C A T+D T D M C+u_{i t}$ Equação 1

No modelo acima, $y_{i t}$ representa o indicador de desempenho da cooperativa $i$ no período $t ; D I R_{t}$ é a variável de interesse (dummy de direcionamento produtivo) tal que 
$D I R_{t}=0$ nos períodos anteriores às mudanças regulatórias no microcrédito (ocorrida em 2011) e $D I R_{t}=1$ nos períodos subsequentes à referida mudança; $M C_{i}$ é uma dummy de grupo, tal que $M C_{i}=1$ se a cooperativa $i$ opera com microcrédito e $M C_{i}=0$ caso contrário; $(M C \times D I R)_{i t}$ representa a interação das duas dummies, tal que $(M C \times D I R)_{i t}=1$ para as cooperativas que fazem microcrédito observadas nos períodos subsequentes à mudança regulatória e $(M C \times D I R)_{i t}=0$ caso contrário; $L C A T$ e $D T D M C$ são as variáveis de controle sendo $L C A T$, o log da carteira ativa (uma proxy de tamanho) e DTDMC uma duummy de interação entre as dummies de tempo $(T D)$ e a dummy de grupo $(M C)$; finalmente, $u_{i t}$ é o termo de erro do modelo. O parâmetro de interesse é $\beta_{3}$, o qual captura, sob a suposição de tendências paralelas, o efeito da mudança regulatória sobre o desempenho das cooperativas que fazem microcrédito. O pressuposto de tendências paralelas indica que o comportamento ou a tendência de evolução dos indicadores/variáveis nos dois grupos (tratamento e controle) se assemelham. Diferentes versões do modelo acima foram estimadas nesta pesquisa, por exemplo, acrescentando outras variáveis de controle ou utilizando um conjunto completo de dummies de tempo, além da estimação por métodos de Efeitos Fixos no lugar da estimação por $M Q O$ (Wooldridge, 2010).

Para a inferência causal, é necessário assumir que as diferenças nas médias dos indicadores de desempenho entre os grupos de "tratamento" (cooperativas que fazem microcrédito) e de "controle" (demais cooperativas) permaneceriam inalteradas durante todo o período amostral na ausência do "tratamento" (ou seja, se não houvesse mudanças regulatórias no microcrédito).

Desse modo, estimou-se uma regressão para cada uma das variáveis constitutivas dos grupos de indicadores financeiros e sociais esperando-se um efeito negativo e estatisticamente significante nas variáveis que compõem os indicadores financeiros e, de outro modo, um efeito significante e positivo nas variáveis constitutivas dos indicadores sociais. $\mathrm{O}$ desempenho financeiro pode ser piorado em consequência da redução das taxas de juros e da TAC. O desempenho social, notadamente em termos de amplitude do alcance, provavelmente melhore em virtude do crescimento da oferta de microcrédito após as medidas.

\subsection{Limitações metodológicas do estudo}

As pesquisas em ciências sociais aplicadas, sobretudo em Contabilidade, enfrentam grandes desafios. Esses desafios passam por disponibilidade de dados e escolhas metodológicas, além do caráter dinâmico dos fenômenos sociais. No segmento de 
microcrédito no Brasil, os desafios são ainda maiores. Portanto, fazer pesquisa nessas áreas implica, necessariamente correr riscos, e evitar riscos significa não pesquisar.

Uma das limitações desta pesquisa diz respeito à delimitação do escopo do estudo. Parte desta delimitação deve-se à incipiência e à baixa qualidade dos dados relacionados ao segmento do microcrédito no Brasil, além da dificuldade de acesso a eles. Sendo assim, se fez necessário contornar alguns obstáculos relacionados à sua coleta.

Ao se perceber que os dados do MTE não permitiriam um estudo suficientemente aprofundado e consistente, buscou-se a realização das entrevistas. Ao enfrentar dificuldades e resistências por parte dos agentes capazes de fornecer as informações necessárias, buscou-se adicionalmente os dados do $\mathrm{BCB}$, de modo a ter uma triangulação de fontes de dados capaz de trazer uma melhor compreensão do segmento, bem como de mitigar as limitações e riscos de cada uma das fontes, isoladamente. Os dados do BCB, por sua vez, além das recentes mudanças metodológicas e conceituais que podem comprometer a qualidade, ainda são específicos de um tipo de instituição, o que não permite a generalização e extrapolação do presente estudo para o mercado de microcrédito em geral. Isto posto, dado que não era possível contornar todas as limitações deste estudo de modo a caracterizar a possibilidade de extrapolação (a validade externa), as escolhas metodológicas de condução da pesquisa foram feitas no sentido de aumentar a sua validade interna.

A montagem operacional da base de dados foi feita mediante a extração de dados oriundos de três bases distintas: SCR, COSIF e dados de fiscalização. Utilizou-se ainda a base de dados pública do cooperativismo do BCB. Não foi identificado nenhum estudo nacional nem internacional que tivesse utilizado uma base de dados semelhante. A maior parte dos estudos quantitativos sobre microcrédito e microfinanças no mundo e no Brasil utilizam a base $M I X$, que além de limitada (a divulgação por parte das instituições é voluntária), encontra-se desatualizada (até dezembro de 2015, somente 23 instituições brasileiras haviam reportado dados de 2014, sendo que uma parcela significativa delas ainda não havia reportado os dados relativos ao exercício social de 2013).

Uma importante limitação deste estudo refere-se às dificuldades para a identificação do efeito causal das mudanças regulatórias. No contexto do desenho metodológico adotado, o principal problema é a possibilidade de que os grupos de "tratamento" e "controle" possuam tendências não paralelas no que tange à evolução de seus indicadores de desempenho ao longo do tempo. Neste caso, eventuais diferenças de médias antes e depois das mudanças regulatórias poderiam ser causadas por fatores não observados e não relacionados ao evento de interesse. As análises de diagnóstico realizadas sugerem que a suposição de tendências 
paralelas é mais plausível para alguns indicadores de desempenho do que para outros. Portanto, mesmo com o acréscimo de variáveis de controle em diversas regressões os resultados devem ser interpretados com cautela. Outro problema é o fato de que a adesão ao CRESCER foi voluntária para as cooperativas de crédito. Logo, embora seja plausível assumir que as cooperativas com vocação para o microcrédito tenderiam a aderir ao programa proposto pelo governo, o "tratamento" não pode ser considerado totalmente exógeno, o que compromete a interpretação causal dos resultados.

A validade interna em um estudo quasi experimental é garantida pela aleatoriedade na escolha dos participantes ou na seleção do grupo de controle. Ocorre que em experimentos naturais nas ciências sociais aplicadas, nas quais se insere a Contabilidade, a aleatoriedade é impossível de ser garantida e compromete a validade interna neste caso. Ainda assim, os estudos experimentais em ciências sociais, notadamente no segmento de microfinanças e microcrédito, têm crescido sobremaneira, principalmente os que tratam de avaliação de impactos (Cozarenco \& Szafarz, 2014; Deininger \& Liu, 2013; Kaboski \& Townsend, 2011; Mallick, 2013).

Sendo assim, espera-se que, a despeito das limitações descritas e reconhecendo a possibilidade de não generalização dos resultados, estes ainda sejam válidos e contributivos para análises, reflexões e discussões acerca do assunto em questão, pois como afirma Shadish, Cook \& Campbel (2002), os quasi experimentos, ainda que não sejam tão robustos, podem produzir estimativas defensáveis, especialmente quando envolvem grupos de controle com cuidadosa combinação de atributos testáveis. Além disso, caso os grupos não sejam homogêneos, pode-se utilizar controles através de ajustes estatísticos. 



\section{RESULTADOS E DISCUSSÃO}

Este capítulo apresenta as análises e reflexões acerca dos resultados apontados pelo estudo. Nele, discutem-se, à luz do referencial teórico e conceitual adotados, os dados observacionais e primários coletados em órgãos públicos federais e também por meio de entrevistas não estruturadas com agentes qualificados.

\subsection{Tratamento e análise dos dados}

Os dados analisados originam-se, como visto, de duas bases: o Ministério do Trabalho e Emprego (MTE) e o Banco Central do Brasil (BCB). Com os dados da base MTE, a análise foi feita por meio da estatística descritiva por ser esta uma etapa exploratória. Estes dados se referem basicamente à oferta de MPO e ao perfil dos clientes. Como a presente pesquisa analisa o MPO do ponto de vista das instituições que o operam, a análise limitou-se aos valores contratados, quantidades de contratos realizados e número de clientes atendidos.

A Figura 21 expressa que, embora a oferta de MPO já estivesse crescendo desde 2008, início da série analisada, até o segundo semestre de 2011, ano do evento estudado, a taxa anual média de crescimento no saldo de contratos ativos foi de $8,83 \%$. Do primeiro semestre de 2012 até o segundo semestre de 2014, essa taxa saltou para 13,22\%. Somente durante o ano de 2013, último ano do cumprimento das metas estabelecidas para os bancos públicos, a taxa média anual de crescimento dos contratos ativos foi de $12,50 \%$.

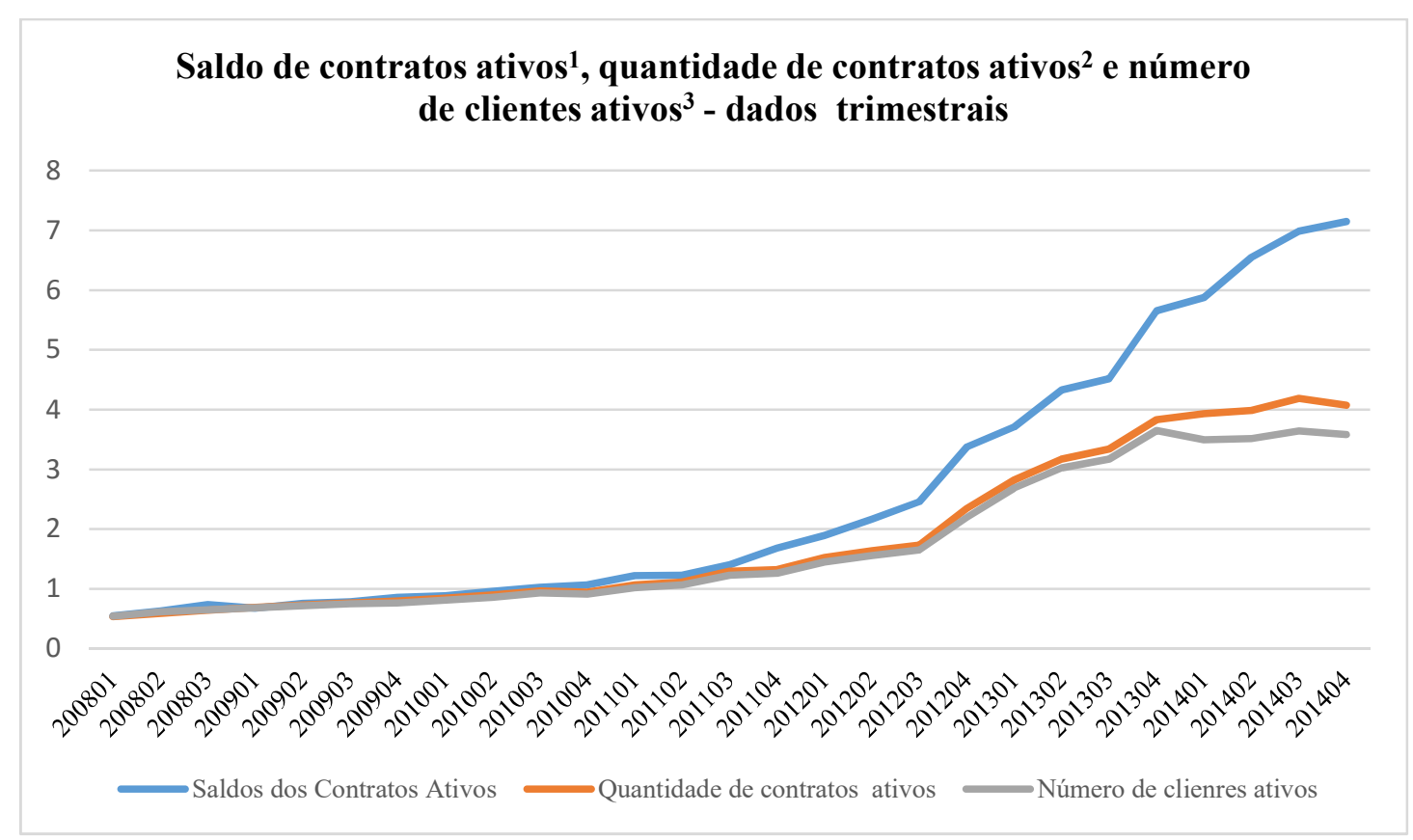


Figura 21: Saldo dos contratos ativos, Quantidade de contratos ativos e Número de clientes ativos - 2008 a 2014 (dados trimestrais)

${ }^{1}$ em R $\$$ bilhões

${ }^{2}$ em R \$ milhões

${ }^{3}$ em R $\$$ milhões

Fonte: Elaboração própria com base nos dados do MTE, 2015.

Nota 1: $\mathrm{O}$ ano de 2008 está em quadrimestre.

Nota 2: Para o MTE, carteira ativa "representa o saldo a receber dos valores emprestados e reflete a capacidade de colocação do microcrédito no âmbito das operações realizadas pelas entidades habilitadas". Relatório PNMPO, $4^{\circ}$ trimestre de 2014, p. 8.

O número de contratos é maior que o número de clientes em razão de uma das características do MPO que é a progressividade dos empréstimos, ou seja, o cliente adimplente pode realizar novos contratos com valores gradualmente maiores. Em relação às quantidades de contratos e de clientes ativos, ocorre o seguinte: até 2011, o crescimento médio anual foi de 7,28\% e 6,87\% respectivamente, e após 2011 , a quantidade de contratos cresceu $9,79 \%$ e a de clientes ativos, 9,06\%.

Em relação aos contratos efetivamente realizados, verifica-se também uma maior ocorrência após 2011, como pode ser observado na Figura 22. Até o segundo semestre de 2011, a taxa anual média de crescimento no saldo de contratos realizados foi de $6,78 \%$. Do primeiro semestre de 2012 até o segundo semestre de 2014, essa taxa foi de 12,85\%. O número de contratos realizados salienta bem os efeitos das mudanças regulatórias no MPO, uma vez que do segundo trimestre para o terceiro trimestre de 2013 (último ano para o cumprimento das metas), o crescimento na realização de contratos foi de $62,43 \%$ e do terceiro para o quarto trimestre houve uma queda de $32,31 \%$ no número de contratos realizados. Desde então o número de contratos realizados continuou crescendo, porém a taxas menores: do quarto trimestre de 2013 para o primeiro trimestre de 2014, cresceu 19,04\%; do primeiro para o segundo trimestre de 2014 , cresceu $8,99 \%$ e; do segundo para o terceiro trimestre de 2014, cresceu $-0,43 \%$, ou seja, decresceu. Essa queda é decorrente do cumprimento total das metas estabelecidas para os bancos públicos no final de 2013.

No que concerne às quantidades de contratos realizados e ao número de contratos realizados por cliente, o crescimento médio anual observado é: até $2011,4,84 \%$ e 4,43\% respectivamente e, após 2011, a quantidade de contratos realizados cresceu 10,70\% e a de contratos realizados por cliente, $9,39 \%$. 


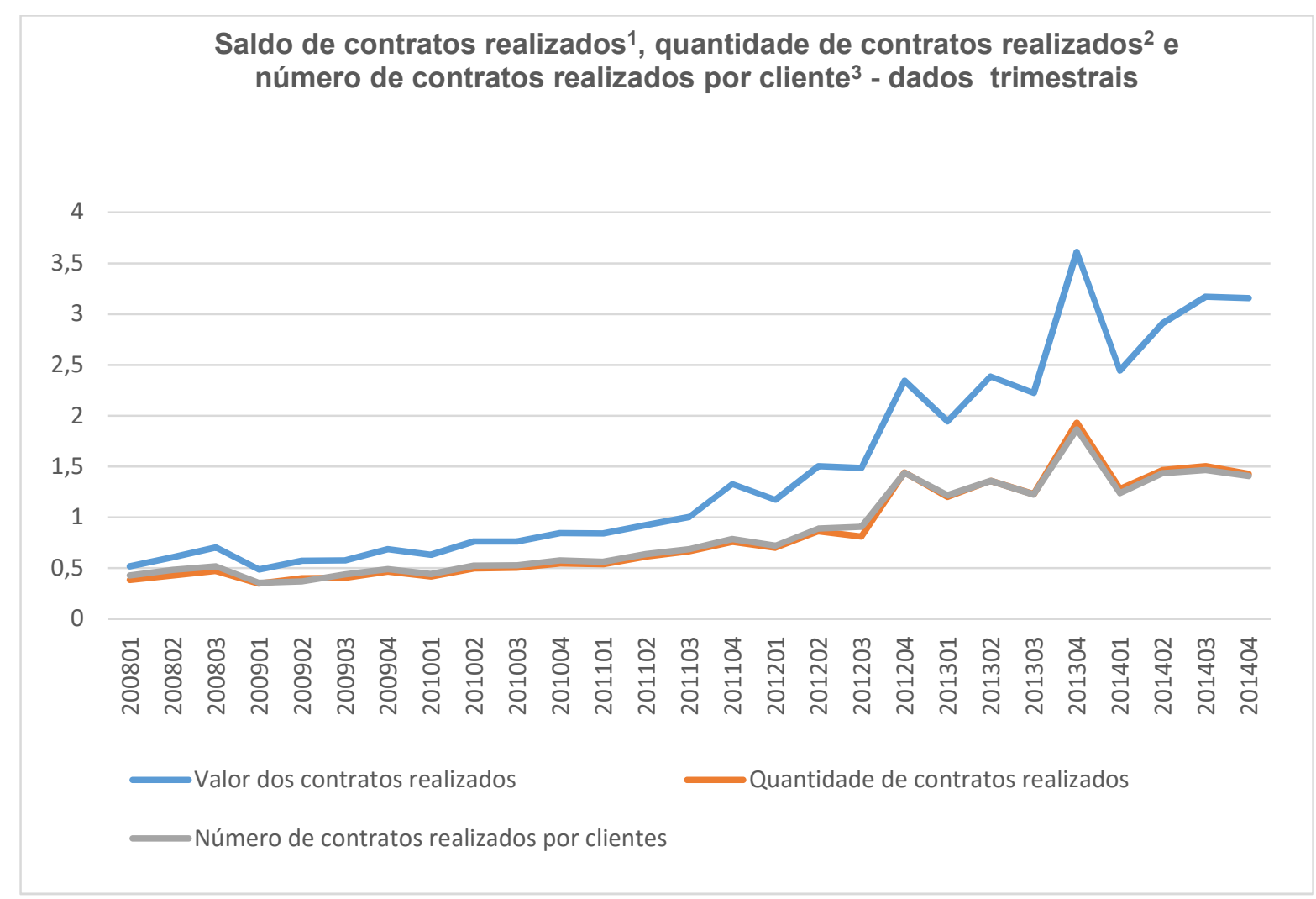

Figura 22: Saldo dos contratos realizados, Quantidade de contratos realizados e Número de contratos realizados por cliente - 2008 a 2014 (dados trimestrais).

1 em R\$ bilhões

2 em R\$ milhões

3 em R\$ milhões

Fonte: Elaboração própria com base nos dados do MTE, 2015.

Nota: O ano de 2008 está em quadrimestre.

Ao analisar os dados separando-os por instituição, torna-se visível a concentração da oferta do MPO pelos bancos públicos, conforme aponta a Figura 23. A referida figura traz evidências empíricas sugestivas do efeito causal das mudanças regulatórias do MPO. No primeiro trimestre de 2008, início da série estudada, os bancos públicos e as OSCIPs praticamente equiparavam-se na oferta de MPO. Ainda em 2008, esse quadro começa a mudar. Os bancos públicos já começam a atuar de forma mais agressiva na oferta de MPO, porém, a partir de 2011, a oferta de MPO pelos bancos públicos cresce muito mais rápido. Além dos bancos públicos, o outro tipo de instituição que teve um leve crescimento na oferta de MPO apesar de nada comparável aos bancos públicos, foram as cooperativas de crédito. As SCMs e agências de fomento não parecem ter sido afetadas por estas mudanças, e as OSCIPs parecem ter sido afetadas negativamente afetadas. A partir de 2009, a participação das OSCIPs na oferta de MPO foi sendo reduzida paulatinamente ao tempo em que a participação dos bancos públicos tem um incremento considerável. 


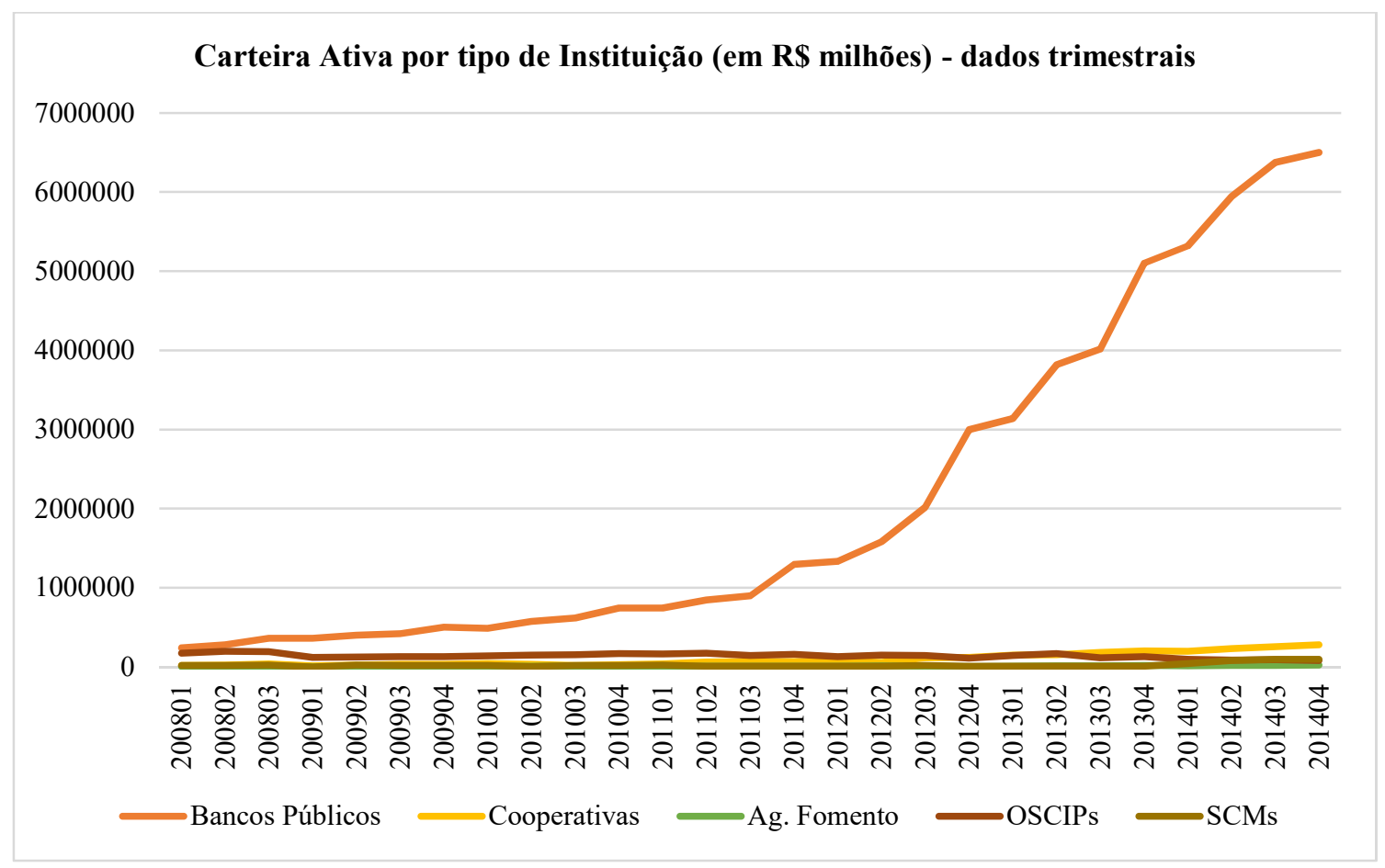

Figura 23: Valor da Carteira Ativa por tipo de Instituição (em R\$ milhões) - dados trimestrais- 2008 a 2014. Fonte: Elaboração própria com base nos dados do MTE, 2015.

Nota: O ano de 2008 está em quadrimestre.

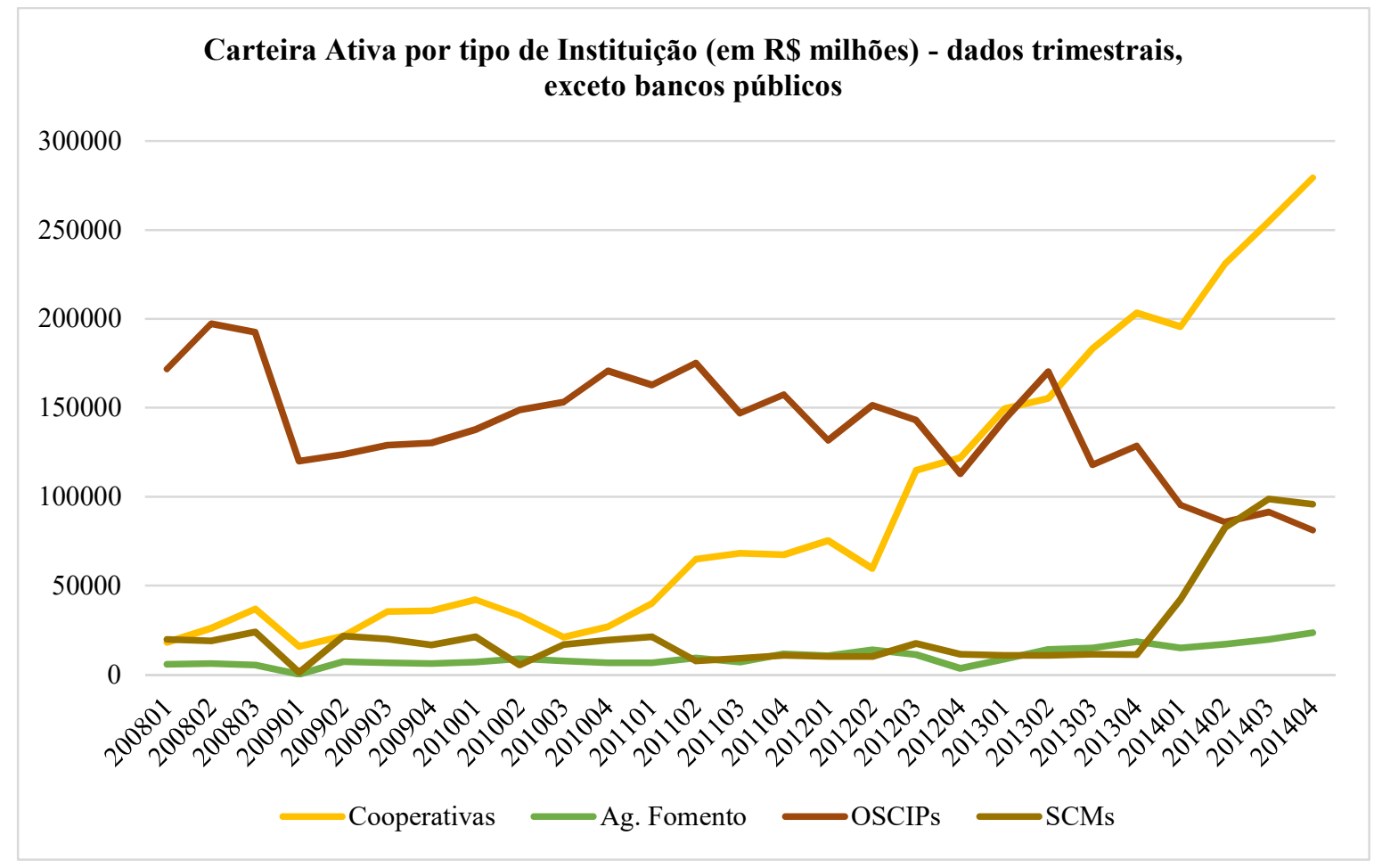

Figura 24: Valor da Carteira Ativa por tipo de Instituição (em R\$ milhões) - dados trimestrais- 2008 a 2014 , exceto bancos públicos ${ }^{19}$.

Fonte: Elaboração própria com base nos dados do MTE, 2015.

Nota: O ano de 2008 está em quadrimestre.

${ }^{19}$ Os bancos públicos foram excluídos porque a diferença nas taxas de crescimento entre estes e os demais tipos de instituições ofertantes de microcrédito é muito grande como mostra a Figura 23. 
No que respeita às OSCIPs, as entrevistas realizadas com informantes qualificados destas instituições corroboram sua perda de espaço na oferta de MPO. Na opinião de um dos entrevistados, com as mudanças ocorridas na gestão do PNMPO em decorrência de mudanças no MTE, as OSCIPs perderam o espaço de interlocução com o governo federal que tiveram no início do programa. Como a transferência de recursos para as OSCIPs via PNMPO foi reduzida, elas tiveram uma relevante redução no seu funding. Aliás, a principal dificuldade que as OSCIPs vêm enfrentando, segundo o mesmo entrevistado, é exatamente a captação de recursos. Por não possuírem autorização para captar recursos com o público, as OSCIPs trabalham basicamente com doações de cooperação internacional e transferências de recursos por meio de bancos de desenvolvimento, a exemplo do BNDES e agências de fomento, além de repasses do governo, caso do PNMPO. Outra dificuldade apontada em outra entrevista é em relação ao marco legal e objetivo da instituição, pois embora as OSCIPs estejam autorizadas a atuarem na área financeira, não são instituições financeiras de fato e não têm a tutela (fiscalização e regulamentação) do BCB. Isso dificulta a captação de recursos com investidores, tornando a alavancagem muito limitada. Outra dificuldade aventada é em relação ao pouco acesso a recursos para desenvolvimento institucional.

Ainda conforme os entrevistados, o programa CRESCER não foi bom para as OSCIPs, porque com a entrada dos bancos públicos no mercado de microcrédito de forma subsidiada, além de aumentar a concorrência, esta gerou uma situação de desigualdade, pois "as OSCIPs não têm cacife para disputar com um banco" (depoimento do entrevistado $\mathrm{n}^{\mathrm{o}} 1$ ).

Quanto às SCMs, a despeito de serem instituições criadas exclusivamente para operar o MPO, têm se mostrado pouco representativas. Com a implementação do PNMPO e, em seguida do CRESCER, diminuíram ainda mais a já reduzida fatia na oferta de microcrédito. No que toca a estas instituições, poucas informações foram encontradas, além dos escassos estudos a respeito e não obstante às diversas tentativas, não foi possível entrevistar nenhum agente ligado a esse segmento.

Referindo-se às Agências de Fomento, de maneira geral, atuam na intermediação de recursos para o MPO, ou seja, repassam recursos para outras instituições como cooperativas de crédito, SCMs e OSCIPs. O funding destas instituições são fundos públicos ou repasses do BNDES. As agências de fomento também são agentes de desenvolvimento e instrumentos de operacionalização de políticas públicas. No caso do PNMPO, elas passam a ter um papel muito mais relevante após o programa CRESCER, embora ainda sejam muito pouco representativas em relação ao total de MPO ofertado. São poucas as que atuam como 
instituições de $2^{\mathrm{a}}$ linha, ou seja, ofertando MPO ao tomador final (um exemplo é a Agência de Desenvolvimento do Estado da Bahia S. A. - Desenbahia), e quando o fazem é em parceira com órgãos públicos a exemplo dos governos estaduais e municipais e também com órgãos de capacitação como o Serviço Brasileiro de Apoio às Micro e Pequenas Empresas (Sebrae). No que remete ao impacto do programa CRESCER, os agentes entrevistados relataram que, no caso de ações de segunda linha, apesar de não terem ainda dados, já era possível perceber um comprometimento da rentabilidade das operações tendo em vista que as taxas de juros foram reduzidas.

No que respeita aos bancos privados no Brasil, mesmo após a Resolução do BCB que direciona $2 \%$ dos depósitos à vista para o microcrédito, estes nunca tiveram uma atuação muito relevante na oferta de microcrédito, sobretudo o produtivo, com exceção do Santander Microcrédito, que já opera o MPO desde 2002. O banco Itaú opera o microcrédito desde quando era Unibanco por meio do controle da SCM Microinvest, criada em 2003, como resultado de uma parceria com a International Finance Corporation (IFC), braço do Banco Mundial. Também já operou por meio da compra de carteira de OSCIPs antes de se tornar Itaú Unibanco. Em 2014, o referido banco estava fortalecendo a metodologia do acompanhamento pelo agente de microcrédito também investindo em educação financeira para microempreendedores. O público-alvo do Itaú Microcrédito são microempreendedores formais e informais das classes D e E. Conforme informações disponibilizadas em material de divulgação do produto, o Itaú Microcrédito tem como parceiros o Banco Interamericano de Desenvolvimento (BID) e o CGAP, organismo ligado ao Banco Mundial. Opera o microcrédito ainda por meio da concessão de linha de crédito para as OSCIPs cadastradas no PNMPO. A taxa de juros inicial é de 3,9\% ao mês, mas reduz a cada renovação; o prazo médio é de até 12 meses e a TAC é de 3\% do valor do contrato. O valor máximo do empréstimo é R\$ 14.200, sendo que 51\% dos contratos estão entre R\$ 400 e R\$ 3 mil.

Já a atuação do Bradesco teve início em 2001, por meio da criação do Banco Postal em parceira com os correios (abertura de novas contas para clientes das classes D e E), mas sua participação está mais presente na inclusão financeira e na oferta de microsseguros tendo pouca inserção na oferta de MPO. Segundo o Conselho Empresarial Brasileiro para o Desenvolvimento Sustentável (CEBDS, 2013, p. 24), em 2013 o Bradesco criou “o primeiro produto de microsseguros aprovado pela Superintendência de Seguros Privados (SUSEP), dando proteção para a residência, para morte acidental e despesas de funeral”, embora antes mesmo da regularização da SUSEP para microsseguros, que ocorreu em 2012, já existia o Primeira Proteção Bradesco. 
O Santander iniciou suas operações no mercado de microcrédito, do mesmo modo que o Banco do Nordeste, com apoio técnico da Accion Internacional. A metodologia adotada para a concessão do MPO foi modelada com o apoio dessa organização. Essa parceria durou em torno de dois anos, e a partir daí o Santander Microcrédito aperfeiçoou o modelo. O Santander atua exclusivamente com o microcrédito produtivo orientado urbano.

A metodologia foi aprimorada pela instituição e possui no agente de crédito o papel chave. O agente faz a prospecção, a análise socioeconômica, as entrevistas e também uma reunião de consolidação, mas não aprova o crédito. A aprovação ou não é realizada por um comitê de crédito. O comitê é composto por, no mínimo, três pessoas incluindo o agente de crédito. Todos são funcionários da Santander Microcrédito, uma subsidiária do Banco Santander. O risco de crédito também é assumido pela Santander Microcrédito. Somente o funding é do banco. O banco paga uma comissão à Santander Microcrédito pela intermediação, e todos os contratos são registrados no banco. O primeiro crédito é concedido exclusivamente para grupos solidários. Somente a renovação (não necessariamente na primeira) é feita de forma individual. Os recursos (100\%) são da exigibilidade - $2 \%$ dos depósitos à vista.

O programa CRESCER e as Resoluções do BCB n⿳o 4.000/2011 (BCB, 2011) e $\mathrm{n}^{\mathrm{o}}$ 4.153/2012 (BCB, 2012a) na opinião dos informantes dos bancos privados entrevistados, trouxeram mudanças positivas. A exigência da aplicação de $80 \%$ dos recursos, no mínimo, para o MPO, foi avaliada como benéfica para os bancos privados que ofertam MPO. Já a redução dos juros, implementada pelo programa CRESCER, teve impacto negativo no tomador final, porque o custo do dinheiro ficou muito baixo. Isso levou muitos a realizarem o empréstimo, mesmo sem estar precisando em virtude da oportunidade considerada excepcional e isso, na opinião de um dos informantes, gerou endividamento, apesar de ainda não ter comprovação desse fato.

Outro aspecto importante do MPO percebido nas entrevistas é a importância do acompanhamento do crédito associado à relação de confiança entre o tomador e o agente de crédito. Assim, outro ponto negativo do programa CRESCER, descoberto nas entrevistas, é a falta de orientação financeira na oferta de MPO. Como os bancos públicos tinham metas a serem cumpridas, não foram muito criteriosos quanto a esse quesito indispensável em qualquer operação de MPO. "Não é no balcão de uma agência que você faz o microcrédito, você faz o microcrédito é dentro da atividade do empreendedor" (Depoimento do entrevistado $\mathrm{n}^{\mathrm{o}}$ 6). 
Outra questão aventada nas entrevistas é que nenhum banco privado aderiu ao CRESCER, não sendo considerado operacionalmente sustentável, pois a taxa de juros estipulada pela lei não é financeiramente viável. "Se você aderisse ao CRESCER, você iria quebrar" (Depoimento do entrevistado n⿳0 6). Outra afirmação do mesmo entrevistado é que “O princípio do programa é louvável, que é permitir o acesso ao microcrédito, mas as condições para a oferta desse crédito não são adequadas".

Em relação aos bancos públicos, tanto os dados do MTE quanto as entrevistas realizadas, além da literatura analisada, evidenciam a concentração da oferta de microcrédito pelo Banco do Nordeste por meio do programa Crediamigo, já mencionado.

A Caixa, mesmo tendo iniciado suas operações de microcrédito em 2000, só apresentou crescimento substancial a partir de 2011, quando foi criada a Caixa CRESCER, uma subsidiária específica para operar o programa CRESCER.

O Banco do Brasil iniciou sua atuação no mercado de microcrédito em 2004, com o BB Crédito Pronto, porém, do mesmo modo que a Caixa, passou a ter papel importante também na oferta de MPO após o programa CRESCER.

Já os bancos de desenvolvimento (Bando do Nordeste, Banco da Amazônia e BNDES) possuem uma atuação muito mais agressiva na oferta de microcrédito, especialmente o Banco do Nordeste. A atuação do BNDES no segmento de microcrédito inicia-se em 1996, quando foi criado o Programa de Crédito Produtivo Popular (PCPP) visando ofertar funding para os agentes repassadores de microcrédito o qual, em 2003, foi substituído pelo Programa de Microcrédito (PM), que durou dois anos. Em março de 2005, buscando um maior alinhamento com o PNMPO, o BNDES instituiu o atual Programa de Microcrédito do BNDES (PMC). Em 2010, o PMC também foi substituído pelo Programa BNDES Microcrédito, que em 2014 se tornou um produto do BNDES, sendo oferecido de forma constante pelo Banco, sem prazo de vigência. Outra mudança no programa foi a sua divisão em dois subprogramas, BNDES Microcrédito Agente Financeiro (instituições de $1^{\circ}$ piso) e BNDES Microcrédito Agente Repassador (instituições de $2^{\underline{o}}$ piso). O custo financeiro para os agentes de $1^{\underline{o}}$ piso foi reduzido (em 2015 era TJLP acrescida de $0,9 \%$ a.a) e a receita bruta anual dos beneficiários subiu de R\$240 mil para até R\$ 360 mil, sendo que o valor máximo de financiamento para o tomador final passou para R $\$ 20$ mil (www.bndes.gov.br).

O Banco da Amazônia, que em 2002 deixou de usar a sigla BASA, atua no segmento de microcrédito tanto na área urbana quanto na rural, com ênfase nesta última. No intuito de atender à Lei do PNMPO), o Banco da Amazônia implantou o Programa Amazônia Florescer, o qual é operacionalizado diretamente com os tomadores finais do crédito, no local onde a 
atividade econômica é desenvolvida, por meio de acompanhamento. Em 2013, das 46.616 contratações, 39.064 clientes eram do setor urbano e 7.552, do rural (www.bancoamazonia.com.br/index.php/governo/microcredito).

Já o Banco do Nordeste, maior banco de desenvolvimento regional da América Latina, possui o maior programa de microcrédito produtivo orientado da América do Sul, o Crediamigo. O Banco do Nordeste é um banco público com atuação regional e o principal executor das políticas públicas de microcrédito do governo federal para a região Nordeste.

Do mesmo modo que o Banco da Amazônia, o Banco do Nordeste atua no segmento rural, com o Agroamigo e no urbano, com o Crediamigo. O Crediamigo foi criado em 1995 e, em 2011, passou a fazer parte do CRESCER.

O Banco do Nordeste utiliza a metodologia do acompanhamento. Os agentes de crédito desta instituição são contratados, capacitados e remunerados pela OSCIP Instituto Nordeste Cidadania (INEC), criada e mantida pelo Banco do Nordeste exclusivamente para operar o Crediamigo. O agente visita o cliente, analisa e aprova o crédito e faz o acompanhamento antes, durante e após a concessão do crédito. A aprovação final, assim como o risco do crédito, é de responsabilidade do banco. Um dos entrevistados afirmou que “o segredo do sucesso do Crediamigo é seguir, à risca, a metodologia criada e disseminada pela Accion Internacional" (Depoimento do entrevistado $\mathrm{n}^{\mathrm{o}}$ 5). Essa metodologia consiste na formação de grupos de, no mínimo, três empreendedores, que se avalizam entre si para obtenção dos empréstimos. O empréstimo é feito mediante o atendimento personalizado de um assessor de crédito, sendo o acompanhamento feito a cada um dos membros que devem ter proximidade geográfica para facilitar o trabalho.

No que tange às cooperativas de crédito, tipo de instituição que essa pesquisa investigou com mais profundidade, as que ofertaram MPO no período analisado, de acordo com a base de dados do MTE, são de dois tipos: crédito mútuo e crédito rural, sendo as primeiras predominantes. Dentre elas, predominam as que possuem viés solidário. Isso comprova o foco do PNMPO no pequeno empreendedor urbano.

Os dados do MTE, além de dados publicados pelo BCB, evidenciaram a percepção de que, a despeito da pouca participação das cooperativas de crédito na oferta de MPO, elas constituem o segundo tipo com maior participação, ficando atrás somente dos bancos públicos. Em termos de quantidade de instituições, elas são a maioria.

As entrevistas realizadas nas cooperativas de crédito ensejaram algumas percepções. Embora possuam a mesma constituição jurídica, mesma forma de gestão e estejam sob a égide da mesma regulamentação, a maioria das que ofertam MPO ou pertencem ao segmento 
denominado solidário ou se aproximam muito destes ideais, quais sejam, compromisso e preocupação com a comunidade local (um dos princípios do cooperativismo), além da responsabilidade com a inclusão financeira da parcela da população que se encontra fora do sistema financeiro formal. O PNMPO e o CRESCER foram considerados por estas uma uma oportunidade de atender às demandas financeiras dos micro e pequenos empreendedores urbanos.

De acordo com a lei do PNMPO e do CRESCER, às cooperativas de crédito é facultativa a adesão a qualquer programa de microcrédito. Sendo assim, grande parte das que o fizeram, possuem vocação e/ou experiência com a metodologia inerente ao MPO, qual seja, aval solidário, que exige a formação de grupos com interesses comuns; proximidade com o cliente e acompanhamento de um agente de crédito; e a consciência de que o resultado da operação não pode ser olhado somente sob o prisma econômico-financeiro. Isso, aliás, consta nos princípios originais do cooperativismo não por acaso, está na essência das microfinanças e do microcrédito.

Contudo, nem todas as cooperativas no Brasil continuam fiéis a esses princípios. O estudo de Búrigo (2006) constatou que grande parte do cooperativismo de crédito brasileiro foi cooptado pelo governo, sobretudo o governo militar, transformando-se em instituições financeiras similares às demais, que buscam prioritariamente o resultado econômico em detrimento de seus objetivos sociais. Segundo o autor, historicamente o governo brasileiro sempre controlou as cooperativas em geral, incluindo as de crédito, para evitar que se tornassem instrumentos de emancipação política e empoderamento das classes menos favorecidas. Desse modo, grande parte das cooperativas se dissociou dos princípios originais do cooperativismo. Por conseguinte, essas cooperativas, em geral grandes e com estruturas mais engessadas e sem a tecnologia e a experiência do microcrédito, não acharam interessante nem viável aderir aos programas PNMPO e CRESCER.

Por fim, as percepções dos entrevistados sobre os tipos de instituições mencionadas acerca do PNMPO/CRESCER convergem nos seguintes aspectos: (a) o objetivo do programa, que claramente foi massificar o microcrédito, foi atingido; (b) a escolha dos bancos públicos para a operacionalização dos programas, em especial o CRESCER, para o qual foram estipuladas metas para estes bancos, foi a maneira mais fácil que o governo de então encontrou para atender ao objetivo da massificação, uma vez que estes bancos possuem infraestrutura adequada para dar capilaridade ao MPO, principalmente pelo viés desenvolvimentista presente na maioria deles. No que diz respeito aos principais entraves, as coincidências prevalecentes nas visões dos entrevistados são: (1) a diminuta taxa de 
bancarização da população, sobretudo nas regiões mais distantes; (2) a dificuldade do agente de crédito chegar aos locais mais distantes e de difícil acesso para prospectar novos clientes e dar o devido acompanhamento no local do empreendimento - o agente de crédito precisa fazer uma busca ativa, literalmente bater na porta do empreendedor; (3) a limitada oferta, principalmente pelos bancos privados e cooperativas de crédito; (4) o pouco conhecimento da tecnologia e a pequena experiência na oferta de MPO pela maioria das instituições ofertantes; o insuficiente nível de educação financeira da população.

\subsection{Caracterização da população (grupo de tratamento $x$ grupo de controle)}

Como visto, os tipos de instituições que ofertam microcrédito no Brasil vão de ONGs a bancos de desenvolvimento. Sabe-se que as ONGs não foram incluídas no PNMPO. Somente as que optaram por se transformar em OSCIPs e se cadastraram como tal no MTE. A escolha do tipo cooperativa de crédito para um estudo mais aprofundado a respeito do impacto de uma mudança regulatória foi quase por exclusão. Discutiu-se no capítulo Metodologia, que um estudo nos bancos de desenvolvimento e agências de fomento é complicado em razão destas instituições atuarem como intermediárias, e assim seria muito difícil fazer uma análise de impacto por meio de seus indicadores. Em relação aos bancos públicos, por serem bancos múltiplos e de porte muito grande, além de alguns também desempenharem a função de agentes de desenvolvimento, a exemplo do Banco do Nordeste e Banco da Amazônia, também se torna muito complexa uma avaliação dessa natureza, uma vez que o microcrédito representa muito pouco em relação à carteira total de crédito e dificilmente se conseguiria capturar qualquer efeito em seus indicadores. No que concerne aos bancos privados, também são bancos múltiplos e ainda são muito poucos os que atuam na oferta de microcrédito, como já dito. Do mesmo modo um estudo nas SCMs, por constituírem reduzido número de instituições, não garantiria validade estatística. Por conseguinte, o tipo de instituição usado como "laboratório" é o das cooperativas de crédito pelas razões já apresentadas, por considerar-se o tipo mais adequado à analise desenvolvida no presente estudo.

A Tabela 7 mostra o crescimento do número de cooperativas habilitadas no MTE durante o período estudado. Até 2011, o crescimento médio do número de cooperativas habilitadas foi de 7,91\%. Após 2011, essa taxa mais que quadriplicou, passando para $36,31 \%$. 
Tabela 7: Evolução do número de cooperativas habilitadas no MTE

\begin{tabular}{|c|c|c|}
\hline Período & Quantidade de cooperativas ${ }^{1}$ & $\%$ crescimento \\
\hline 2008 & 125 & \\
\hline 2009 & 127 & $1,60 \%$ \\
\hline 2010 & 147 & $15,75 \%$ \\
\hline 2011 & 168 & $14,29 \%$ \\
\hline 2012 & 168 & $0,00 \%$ \\
\hline 2013 & NI & $0,00 \%$ \\
\hline 2014 & 290 & $72,62 \%$ \\
\hline
\end{tabular}

Fonte: Elaboração própria com base nos Relatórios trimestrais do PNMPO de 2008 a 2014.

${ }^{1}$ Este número diverge dos dados da base do $\mathrm{BCB}$ em decorrência das divergências na concepção de microcrédito pelos dois órgãos (MTE e BCB). Para efeito de registro no SCR, operações de microcrédito são exclusivamente aquelas que seguem a Resolução $\mathrm{n}^{\mathrm{o}}$ 4.152/2012 (BCB, 2012).

Não obstante, as mudanças regulatórias analisadas neste estudo são a Resolução do $\mathrm{BCB} \mathrm{n}^{\mathrm{o}}$ 4.000/2011 (BCB, 2011), a qual determinou que ao menos $80 \%$ dos recursos destinados ao microcrédito fossem direcionados para o microcrédito produtivo; e a Lei $\mathrm{n}^{\mathrm{o}}$ 12.666/2012 (Brasil, 2012), que criou o CRESCER - Programa Nacional de Microcrédito. Para os bancos públicos, houve a obrigatoriedade da adesão ao CRESCER, além de lhe terem sido impostas metas a serem cumpridas quanto a valores e número de contratos. Um estudo nesse tipo de instituição garantiria maior grau de exogeneidade ao evento. Ocorre que, como discutido no Capítulo III, esse estudo não se mostrou viável ,e a alternativa mais plausível pelas razões já apresentadas também no Capítulo III, foi uma análise nas cooperativas de crédito. $\mathrm{O}$ fato de as cooperativas poderem escolher se querem aderir ou não ao CRESCER ou ainda se direcionam ou não os $2 \%$ dos recursos dos depósitos à vista para o microcrédito, pode refletir questões endógenas, não configurando, assim, um grupo de controle ideal. Sem embargo, dadas as características das cooperativas, já discutidas, e comparando-as aos demais tipos de instituições que ofertam microcrédito, estas revelaram-se como o tipo mais oportuno a um estudo quasi experimental conduzido pela análise de diferenças em diferenças.

Sendo assim, o primeiro procedimento em uma pesquisa quasi experimental, ou experimento natural, é a caracterização dos grupos (de controle e de tratamento). A amostra da pesquisa consiste em toda a população de cooperativas de crédito singulares (as cooperativas centrais não fazem parte do escopo do estudo) que estavam em funcionamento durante o período de 2008 a 2014, perfazendo um total de 1.429 cooperativas observadas durante 14 semestres, configurando, assim, um conjunto de dados em painel desbalanceado.

Partindo-se para a análise dos dados da base $\mathrm{BCB}$, o primeiro passo foi o exame da estatística descritiva quando se observa que as cooperativas ofertantes de microcrédito (grupo de tratamento) as quais correspondem ao grupo de tratamento estão predominantemente localizadas nas regiões Sul e Sudeste. No Sudeste, a maior parte está aglutinada no estado de 
Minas Gerais (25,6\%) e no Sul, nos estados do Rio Grande do Sul (22,3\%) e em Santa Catarina $(19,4 \%)$. Esta maior concentração no oeste catarinense e no semiárido baiano decorre do fato de que lá surgiram as primeiras cooperativas solidárias. Em relação às cooperativas que não ofertam microcrédito (grupo de controle), também se concentram nas mesmas regiões (Sul e Sudeste), diferenciando-se do outro grupo somente em relação ao estado predominante na região Sul que, neste caso, é o Paraná com 15\% das cooperativas. Esta é mais uma evidência da predominância da oferta de microcrédito, em maior parte, pelas cooperativas de crédito solidárias. Estes achados coincidem com os resultados da pesquisa de Belloni et al. (2015), a qual constatou que o cooperativismo é mais presente na região Sul, especialmente no estado do Rio Grande do Sul.

No que respeita aos tipos de cooperativa, os grupos (de tratamento e de controle) diferenciam-se um pouco. Dentre as que ofertam microcrédito, predominam os tipos: cooperativas de livre admissão, localizadas em municípios com até 300 mil habitantes, com $53,31 \%$ da amostra; de crédito rural, com $14,47 \%$ e de livre admissão - população de 300 a 750 mil habitantes, com $14,86 \%$. Entre as que não operam o microcrédito, os tipos mais frequentes são: crédito mútuo, com $21,42 \%$ da amostra; crédito rural, com $27,05 \%$ e de livre admissão localizadas em municípios com até 300 mil habitantes, com 19,58\%.

Percebe-se que são muitos os tipos de cooperativas de crédito. Assim, foram feitas algumas combinações (matchings) intragrupos, a fim de encontrar subgrupos que pudessem ser mais homogêneos e, consequentemente, mais comparáveis entre si. Foram testadas diversas possibilidades, a saber:

(a) Testou-se um primeiro conjunto de regressões com as cooperativas do tipo crédito mútuo. Destas, 10,35\% fazem microcrédito e $89,65 \%$ não o fazem;

(b) Uma segunda simulação foi feita somente com as cooperativas de livre admissão, localizadas em municípios de até 300 mil habitantes;

(c) Outro teste foi empreendido com cooperativas de crédito rural, somente;

(d) A segunda simulação foi realizada com um grupo formado pela combinação dos tipos crédito rural e de livre admissão, localizadas em municípios de até 300 mil habitantes;

(e) Um terceiro grupo de combinações comtemplou as cooperativas de crédito mútuo e de livre admissão, localizadas em municípios de até 300 mil habitantes;

Em termos de significância estatística, os achados não apresentaram diferença alguma, de forma que apenas os valores dos coeficientes estimados mudaram em função da mudança da amostra. Ademais, o número de observações, obviamente, foi reduzido a cada grupo de 
combinações. O fato de, mesmo com significativa redução do número de observações, os resultados dos testes não terem sido alterados de forma substancial e as significâncias estatísticas continuaram iguais indica que os grupos podem ser comparados entre si.

Outro indício de comparabilidade entre os grupos é a coincidência dos tipos de cooperativas mais frequentes: tanto o grupo de controle como o de tratamento contemplam dois dos tipos mais frequentes, quais sejam, as cooperativas de livre admissão, localizadas em municípios com até 300 mil habitantes, e as de crédito rural. Vale ressaltar que os dados das cooperativas de crédito rural, tanto os da base MTE como os da base BCB, referem-se exclusivamente à oferta de MPO não sendo incluído o Programa Nacional de Fortalecimento da Agricultura Familiar (Pronaf). O Pronaf é um programa de crédito rural, e o crédito rural no Brasil possui legislação e metodologias específicas, as quais diferem do microcrédito aqui analisado, que é preponderantemente urbano.

Outro critério que torna razoável a comparabilidade entre os grupos refere-se à confluência das modalidades de crédito ofertadas. Diferentemente de algumas IMFs, como as OSCIPs e SCMs que operam somente o microcrédito, as cooperativas de crédito, embora trabalhem exclusivamente com crédito, possuem outras modalidades de crédito. A Tabela 8 mostra as modalidades de crédito mais frequentes em cada grupo de cooperativas.

Tabela 8: Modalidades de crédito ofertadas pelas cooperativas por grupo (de tratamento e de controle)

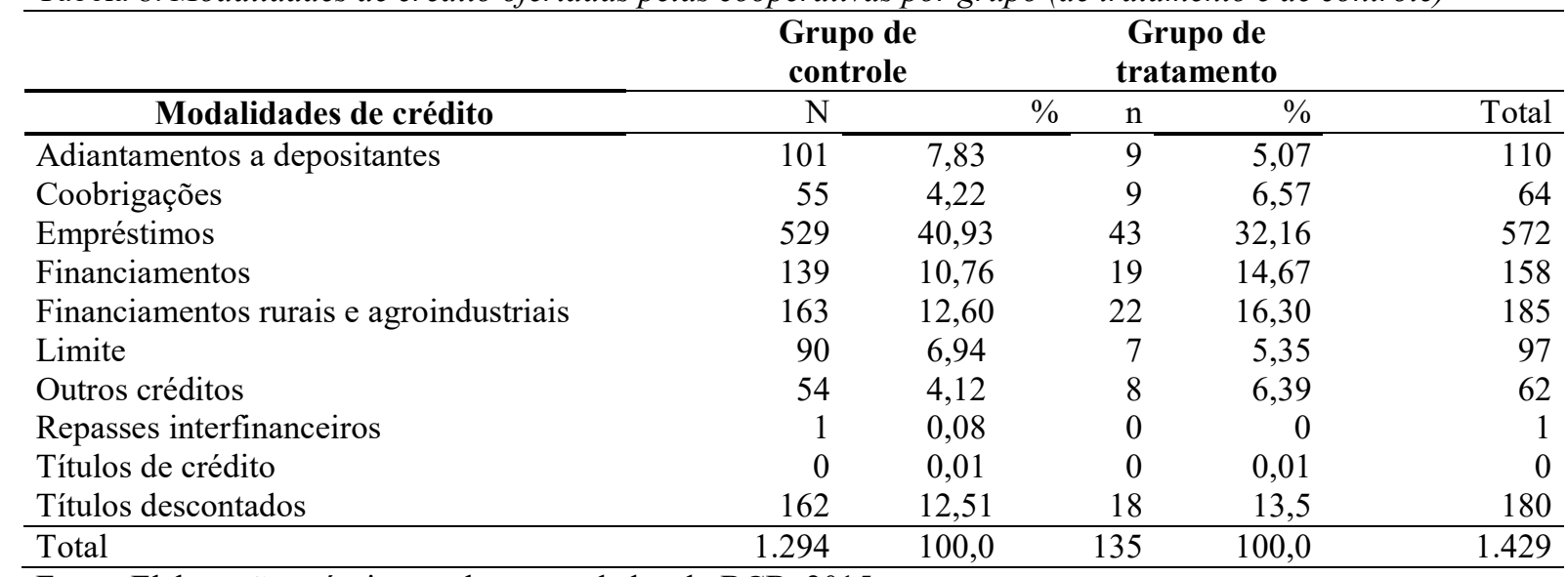

Fonte: Elaboração própria com base nos dados do BCB, 2015.

Como pode ser observado na Tabela 8, neste caso, há homogeneidade nas modalidades de crédito ofertadas, ou seja, nos dois grupos as modalidades mais frequentes são, em ordem decrescente: empréstimos, financiamentos rurais e agroindustriais e financiamentos.

No que se refere às submodalidades de crédito, de acordo com o documento "Leiaute 3040" do SCR, o microcrédito é uma submodalidade das modalidades empréstimos e 
financiamentos. A modalidade empréstimos, além do microcrédito, contempla o crédito consignado, cartão de crédito e cheque especial. O microcrédito empréstimos corresponde ao microcrédito de consumo. A modalidade financiamentos inclui financiamentos de projetos, antecipação de fatura de cartão de crédito, aquisição de bens, além do microcrédito. $\mathrm{O}$ microcrédito financiamentos é o microcrédito produtivo orientado. Como pode ser observado, as operações de microcrédito, somadas às duas submodalidades (empréstimos e financiamentos), correspondem a $13,51 \%$ do total de modalidades nas cooperativas que ofertam microcrédito (grupo de tratamento), ficando atrás do crédito pessoal consignado $(22,6 \%)$ e do desconto de cheques $(31,8 \%)$. Não foi possível analisar de forma separada o microcrédito de consumo e o produtivo, uma vez que as cooperativas somente passaram a informar dados individualmente para cada uma dessas modalidades a partir de 2012, quando entrou em vigor a Resolução do $\mathrm{BCB} \mathrm{n}^{\mathrm{o}}$ 4.000, de 25 de agosto de 2011 (BCB, 2011), a qual determinou que, pelo menos $80 \%$ da exigibilidade destinada ao microcrédito fosse destinada para o microcrédito produtivo orientado, passando assim a exigir essa separação a fim de viabilizar a fiscalização pelo BCB do cumprimento ou não do direcionamento especificado.

A tabela 9 mostra a evolução do microcrédito separando o microcrédito de consumo do produtivo onde é possível verificar que houve claramente uma substituição na oferta de microcrédito de consumo pelo produtivo.

Tabela 9: Evolução do microcrédito - dez/2008 - dez/2014

\begin{tabular}{|c|c|c|c|c|c|}
\hline 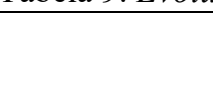 & Microcrédito & Consumo & Microcrédito & Produtivo & $\begin{array}{c}\text { Microcrédito } \\
\text { Total }\end{array}$ \\
\hline Período & $\begin{array}{c}\text { Sado (em RS } \\
\text { milhões) }\end{array}$ & $\begin{array}{c}\text { Part. no } \\
\text { Microcrédito } \\
(\%) \\
\end{array}$ & $\begin{array}{c}\text { Sado (em RS } \\
\text { milhões) }\end{array}$ & $\begin{array}{c}\text { Part. no } \\
\text { Microcrédito } \\
(\%) \\
\end{array}$ & $\begin{array}{l}\text { Sado (em RS } \\
\text { milhões) }\end{array}$ \\
\hline $\mathrm{dez} / 08$ & 879 & 63,33 & 510 & 36,74 & 1.388 \\
\hline $\operatorname{dez} / 09$ & 969 & 56,24 & 754 & 43,76 & 1.723 \\
\hline $\operatorname{dez} / 10$ & 1.440 & 57,17 & 1.078 & 42,79 & 2.519 \\
\hline $\operatorname{dez} / 11$ & 1.002 & 37,70 & 1.656 & 62,30 & 2.658 \\
\hline $\operatorname{dez} / 12$ & 926 & 24,38 & 2.872 & 75,62 & 3.798 \\
\hline $\mathrm{dez} / 13$ & 563 & 10,44 & 4.829 & 89,56 & 5.392 \\
\hline $\operatorname{dez} / 14$ & 198 & 3,54 & 5.396 & 96,46 & 5.594 \\
\hline $\begin{array}{l}\text { Variação real } \\
\text { acumulada }\end{array}$ & $-86 \%$ & - & $879 \%$ & - & $178 \%$ \\
\hline
\end{tabular}

Como apresentado no Capítulo III, um dos pressupostos importantes da técnica estatística diferenças em diferenças é o das tendências paralelas, ou seja, os grupos de comparação, além de apresentarem certa homogeneidade, é necessário também exprimir 
comportamento semelhante antes do evento. Desta forma, qualquer afastamento dessa tendência paralela pós-evento, pode ser atribuída ao efeito do evento. Então, a fim de verificar possíveis diferenças significativas nas variáveis de desempenho das cooperativas, considerando o evento da mudança da regra do direcionamento para o microcrédito produtivo e usando as cooperativas que não fazem microcrédito como controle, observou-se um dois dos mais importantes indicadores analisados pelo presente estudo, a saber: o indicador de desempenho financeiro margem de intermediação financeira (MARG_FIN). A Figura 25 mostra a evolução no comportamento desta variável nos grupos de controle e de tratamento, a qual, pode-se perceber, vinha caminhando em paralelo em ambos. Assim, embora não se possa garantir a validade do pressuposto de tendências paralelas, sendo esta uma limitação importante do presente estudo, o comportamento deste indicador reforça a justificativa da escolha de cooperativas que não fazem microcrédito como um grupo de controle razoável.

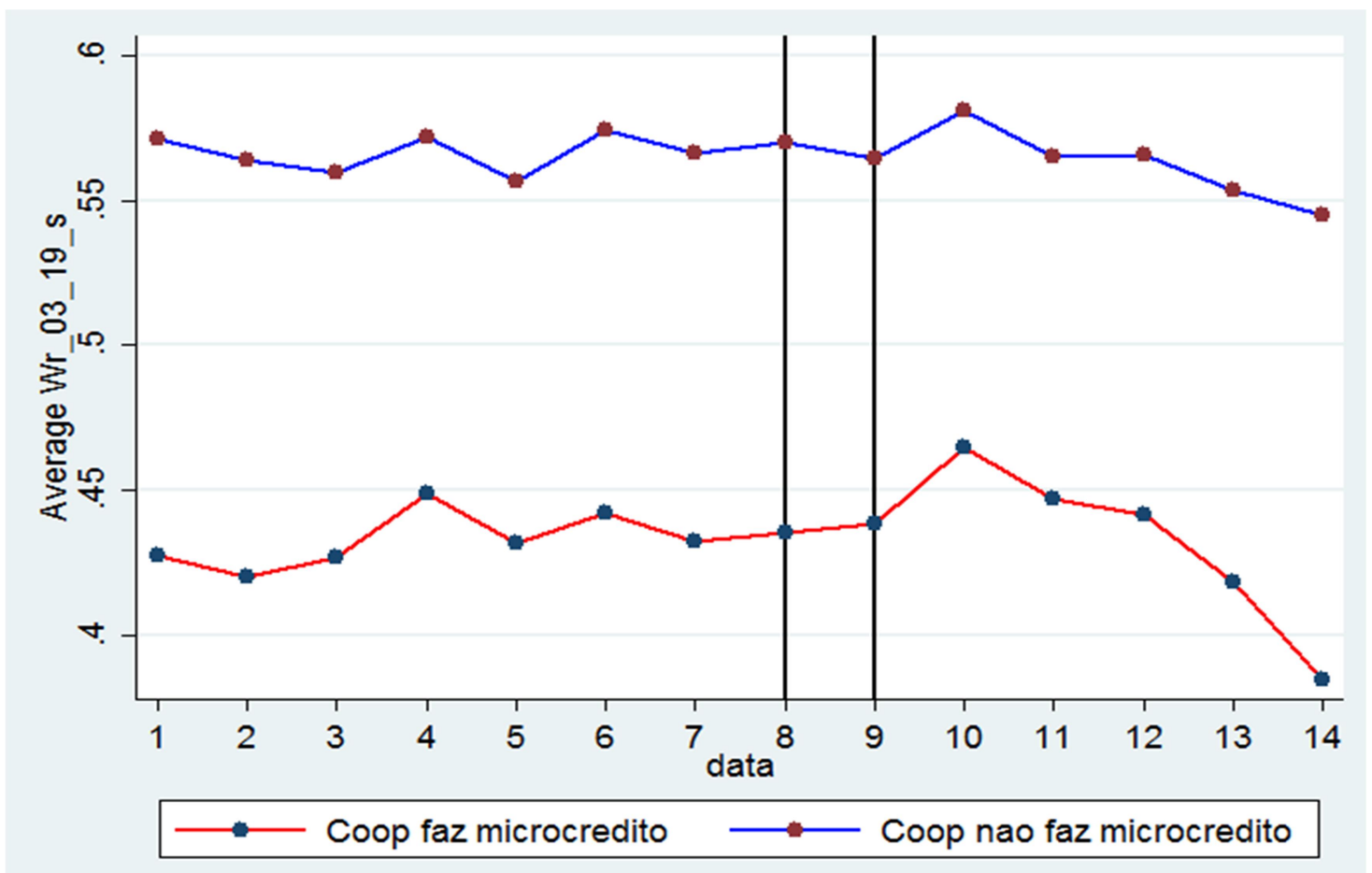

Figura 25: Evolução média do indicador Margem de intermediação financeira (MARG_FIN).

Fonte: Elaboração própria com base nos dados do BCB, 2015.

Nota: os períodos de tempo de 1 a 14 representam a série semestral analisada: o período de tempo de 1 a 8 representa o pré-evento (200806 a 201106), 8-9 constituem o evento (201112) e a partir do período 9, o pósevento (201206 a 201412).

A Figura 25 evidencia ainda que, após 2011 (ano do evento), a margem de intermediação financeira $\left(M A R G_{-} F I N\right)$ caiu para o grupo de cooperativas que fazem microcrédito, a despeito da quantidade de operações ter crescido mais do que cresceu para o grupo das cooperativas que não fazem microcrédito. Isso é uma forte evidência dos efeitos 
das mudanças regulatórias. Mesmo aumentando a escala, a margem de intermediação caiu com mais intensidade para as cooperativas que ofertam microcrédito em função da redução significativa na taxa de juros das operações com microcrédito. Vale ressaltar que o indicador financeiro é composto pelas demais modalidades também, todavia como o microcrédito é a terceira modalidade mais representativa, as mudanças que foram específicas para esta modalidade (microcrédito) acabaram impactando o indicador como um todo, possivelmente.

A Figura 26 representa a média no crescimento do mesmo indicador aqui analisado: margem de intermediação financeira $(M A R G-F I N)$, ou seja, a diferença média da taxa de crescimento da referida variável entre as cooperativas que fazem microcrédito e as cooperativas que não o fazem em cada período de tempo. Constata-se uma pequena mudança no comportamento da variável após o evento (2011), ainda que não seja vultosa.

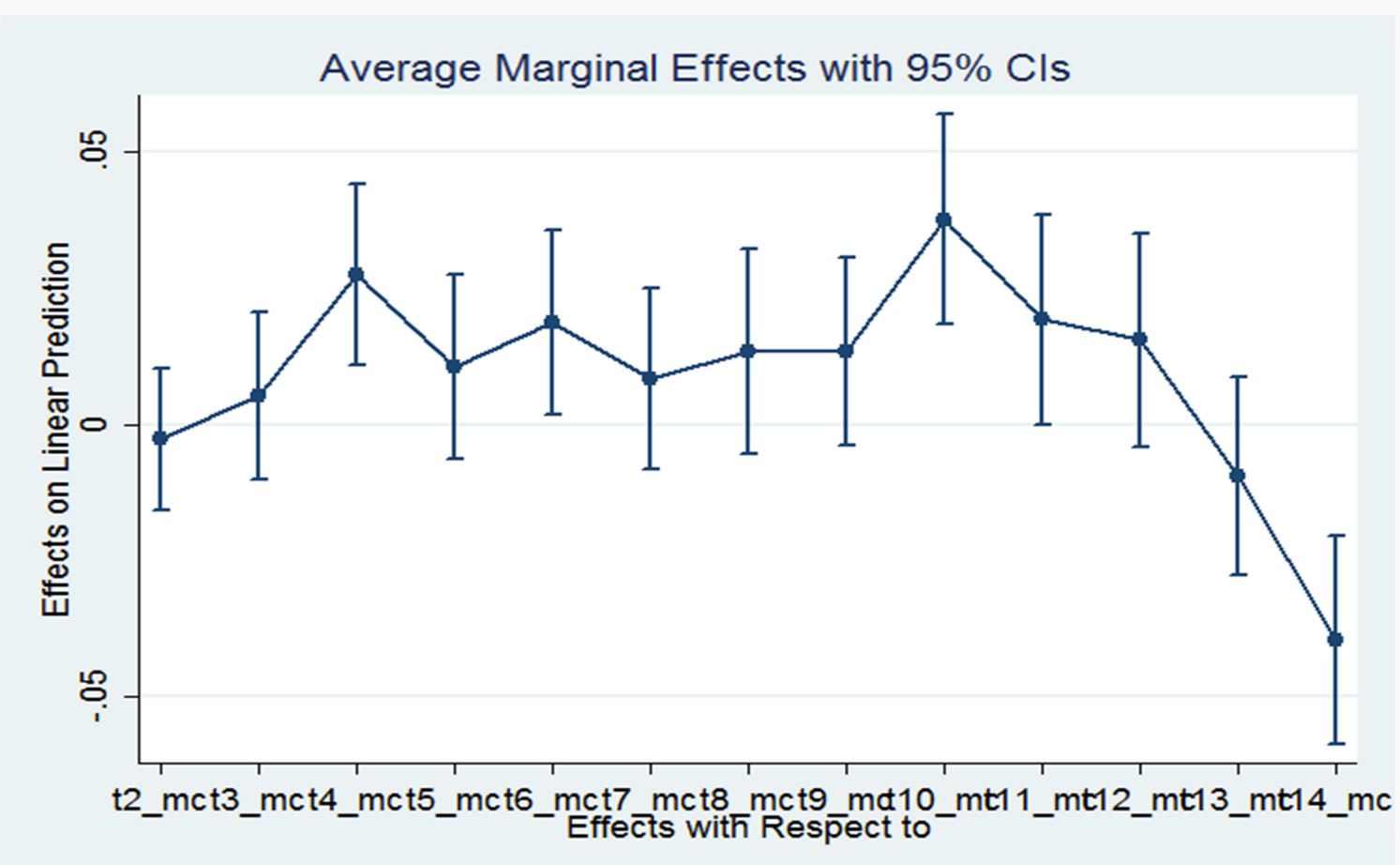

Figura 26: Diferença média de crescimento no indicador financeiro margem de intermediação financeira (MARG_FIN) entre os grupos de controle e de tratamento - intervalo de confiança a 95\%.

Fonte: Elaboração própria com base nos dados do BCB, 2015.

Nota: A dummy de tempo t8_MC representa o momento do evento (201112). As barras evidenciam intervalos de confiança de $95 \%$ e são calculados utilizando o comando "margin" no software estatístico Stata. As estimativas derivam de uma regressão de Mínimos Quadrados Ordinário $(M Q O)$, com dados em painel desbalanceado, efeito fixo, sem controle algum.

Nesse sentido, sem embargo das limitações apresentadas, considera-se o grupo das cooperativas que não ofertam microcrédito um grupo de controle razoável para a averiguação 
dos efeitos das mudanças regulatórias do microcrédito nos indicadores de desempenho financeiro e social das cooperativas de crédito brasileiras.

Outra limitação do presente estudo no que tange à definição do grupo de tratamento diz respeito ao fato de as cooperativas poderem escolher se querem ou não ofertar microcrédito. Assim, o tratamento não pode ser considerado totalmente exógeno.

Não obstante, como apresentado no Capítulo II, as cooperativas que ofertam microcrédito são predominantemente solidárias. Estas cooperativas são, por excelência, comprometidas com a oferta de microcrédito. Desse modo, mesmo tendo sido opcional a adesão ao PNMPO e ao CRESCER, elas possuem uma tradição e experiência não ofertando microcrédito de forma esporádica, sendo as mudanças regulatórias um incentivo ou mesmo uma oportunidade de melhorar o seu alcance social ainda que financeiramente não se apresente uma alternativa interessante. As cooperativas de crédito solidárias, que compõem a maior parte do grupo de tratamento são mais fiéis aos princípios cooperativistas de não buscarem o lucro como um fim em si mesmo, mas sim como um meio de sustentabilidade.

No entanto, vale salientar que, de acordo com o entrevistado $\mathrm{n}^{\mathrm{o}} 06$, exceto os bancos públicos, nenhuma outra IMF aderiu ao CRESCER, porque o subsídio não é suficiente para cobrir o aumento dos custos em decorrência da redução das taxas de juros.

Dito de outra forma, os bancos públicos podem cumprir as metas de direcionamento operando os recursos diretamente ou repassando-os para cooperativas e OSCIPs. Como as OSCIPs não são fiscalizadas pelo BCB, houve, de certa forma uma substituição das OSCIPs pelas cooperativas no que tange ao repasse destes recursos.

Outra característica importante do grupo de tratamento refere-se ao fato de que grande parte das cooperativas que ofertam microcrédito o fazem por vocação e/ou experiência com a metodologia inerente ao MPO, sendo que a maioria das cooperativas que integram esse grupo já tinha este perfil antes do CRESCER.

\subsection{Análise dos resultados}

Sobre a análise dos resultados dos testes estatísticos realizados, inicialmente examinaram-se as estatísticas descritivas das variáveis definidas no Capítulo III. O primeiro passo foi explorar os dados originais quando foram elaborados os gráficos box plot ou "gráficos de bigode", o que permitiu detectar muitos valores discrepantes (outliers). A fim de atenuar os efeitos de observações extremas, todas as variáveis contínuas são tratadas por meio do procedimento denominado winsorização, técnica amplamente utilizada para esse tipo de 
ajuste em bases de dados com diversos valores divergentes. Grosso modo, este procedimento consiste na substituição dos valores extremos, tanto os inferiores quanto os superiores, pelos valores remanescentes (menores e maiores) do limite estabelecido. Esse limite, em geral, varia entre $1 \%$ e $10 \%$. O presente estudo optou pelo limite de $10 \%$. Outra transformação realizada nas variáveis foi a logaritmização de algumas delas, a saber, carteira ativa total $(C A T)$, resultado da intermediação financeira (RESULT_FIN), resultado da intermediação financeira considerando somente juros (RESULT_FIN_J) e inadimplência (INAD). No intuito de demonstrar o alto número de valores discrepantes (outliers), a Tabela 10 mostra a estatística descritiva das variáveis após os tratamentos, ou seja, exclusão de valores nulos e/ou discrepantes, além dos procedimentos da winsorização e da logaritmização. A definição operacional das variáveis encontra-se no Capítulo III.

Tabela 10: Estatística descritiva das variáveis

\begin{tabular}{|c|c|c|c|c|c|c|}
\hline Nome da variável & $\begin{array}{l}\text { Código da } \\
\text { variável }\end{array}$ & $\begin{array}{c}\mathrm{N}^{\mathbf{0}} \text {. } \\
\text { Obs.* }\end{array}$ & Média & $\begin{array}{l}\text { Desvio- } \\
\text { Padrão }\end{array}$ & Min. & Max. \\
\hline \multicolumn{7}{|c|}{ Indicadores financeiros } \\
\hline ROA & r_01_05_s & 17.006 & 0,128 & 3,285 & $-1,000$ & 405,51 \\
\hline MARG_FIN & r_03_19_s & 17.006 & 0,531 & 0,317 & $-13,708$ & 1,000 \\
\hline MARG_OP & r_03_20_s & 17.006 & $-0,115$ & 32,630 & $-4.252,12$ & 1,000 \\
\hline CUST_OP & d_1_1_00_0 & 17.007 & 0,966 & 1,437 & 0,000 & 9,990 \\
\hline RENT_CART & inrdoc_clascart & 17.007 & 0,130 & 0,121 & $-0,138$ & 99,879 \\
\hline $\mathrm{ROE}^{-}$ & r_01_01_s & 17.007 & 268,03 & $33.656,66$ & $-1,000$ & $4.388 .753,00$ \\
\hline REND_JR & r_o2_02_- & 17.007 & 0,421 & 3,242 & $-0,351$ & 371,34 \\
\hline RESUL̄T_FIN & $\operatorname{rsif}^{-}-$ & 17.006 & 678,93 & $1.530,28$ & $-3.321,83$ & $34.311,25$ \\
\hline RESULT_FIN_J & rsifj & 17.006 & 704,79 & $1.609,15$ & $-3.322,01$ & $34.311,25$ \\
\hline INAD - & npl & 17.007 & 214,09 & 667,65 & 0,000 & $26.976,81$ \\
\hline TX_INAD & inad & 17.007 & 0,118 & 4,432 & 0,000 & 406,05 \\
\hline \multicolumn{7}{|c|}{ Indicadores Sociais } \\
\hline CLIEN & soma_cli_om ${ }^{1}$ & 16.994 & $3.220,37$ & $9.263,07$ & 1,000 & $362.251,00$ \\
\hline OPER & soma_op_om ${ }^{2}$ & 16.994 & $6.116,74$ & $48.839,20$ & 1,000 & $2.406 .523,00$ \\
\hline ME_OPER & me_soma_op_om & 16.994 & 2,86 & 11,18 & 0,322 & 479,40 \\
\hline ME_CA & me_soma_lca_om & 16.993 & 0,011 & 0,073 & $-0,118$ & 5,14 \\
\hline
\end{tabular}

A amostra compreende todas as cooperativas de crédito do Sistema Financeiro Nacional com informações disponibilizadas para o período de 2008 a 2014, em semestres, totalizando 1.429 cooperativas observadas durante 14 semestres.

* Número de cooperativas multiplicado pelo número de períodos de tempo.

${ }^{1}$ Total de clientes ativos para as modalidades: 1, 2, 3, 4 e submodalidades 1303 e 1304, 212 - empréstimos (microcrédito consumo) e 403 - financiamentos (microcrédito produtivo).

${ }^{2}$ Total de operações por modalidades: 1, 2, 3, 4 e submodalidades 1303 e 1304, 212 - empréstimos (microcrédito consumo) e 403 - financiamentos (microcrédito produtivo).

Nota 1: ROA: Retorno sobre Ativo; $M A R G \_F I N$ : Margem de intermediação financeira; $M A R G \_O P$ : Margem operacional; CUST_OP: Custo operacional; RENT_CART: Rentabilidade da carteira de crédito; ROE: Retorno sobre o Patrimônio Líquido; REND_JR: Rendas de juros com operações de crédito em relação ao ativo total ajustado; RESULT_FIN: $\log$ do resultado da intermediação financeira; RESULT_FIN_J: log do resultado da intermediação financeira (considerando somente juros); INAD: $\log$ da inadimplência - Carteira em Risco $>90$ dias; TX_INAD: Taxa de inadimplência; CLIEN: Total de clientes; OPER: Total de operações; ME_OPER: Valor médio das operações; $M E \_C A$ : Carteira ativa média;

Nota 2: A variáveis RESULT_FIN, RESULT_FIN_J e INAD foram transformadas por logaritmo.

Nota 3: As variáveis nominais foram deflacionadas pelo IPCA (IBGE). 
Para efeito de verificação da possibilidade de comparabilidade entre os grupos de tratamento (cooperativas que fazem ou em algum momento do período estudado fizeram microcrédito) e controle (cooperativas que não ofertam esta modalidade de crédito), procedeu-se a análise das médias das variáveis antes e após o evento que ocorreu em 2011 (mudanças de regras). Os valores encontram-se nas Tabelas 11 e 12.

Tabela 11: Estatística descritiva das variáveis antes e após as mudanças regulatórias no microcrédito (201112) - Grupo de Tratamento (Cooperativas que fazem microcrédito)

\begin{tabular}{|c|c|c|c|c|c|c|c|}
\hline Nome da variável & Código da variável & Período & $\begin{array}{l}\mathrm{N}^{0} . \\
\text { Obs. }\end{array}$ & Média & $\begin{array}{l}\text { Desvio- } \\
\text { Padrão }\end{array}$ & Min. & Max. \\
\hline \multicolumn{8}{|c|}{ Indicadores financeiros } \\
\hline \multirow[t]{2}{*}{ ROA } & Wr_01_05_s & Antes & 810 & 0,065 & 0,059 & $-0,036$ & 0,261 \\
\hline & & Depois & 818 & 0,067 & 0,055 & $-0,036$ & 0,261 \\
\hline \multirow[t]{2}{*}{ MARG_FIN } & $\mathrm{Wr} 0319 \mathrm{~s}$ & Antes & 810 & 0,436 & 0,118 & 0,260 & 0,829 \\
\hline & & Depois & 818 & 0,436 & 0,109 & 0,260 & 0,811 \\
\hline \multirow[t]{2}{*}{ MARG_OP } & $\mathrm{Wr} 0320 \mathrm{~s}$ & Antes & 818 & 0,156 & 0,102 & $-0,077$ & 0,510 \\
\hline & & Depois & 818 & 0,156 & 0,102 & $-0,077$ & 0,510 \\
\hline \multirow[t]{2}{*}{ CUST_OP } & Wd $11 \quad 1 \quad 00 \quad 0$ & Antes & 810 & 0,675 & 0,175 & 0,354 & 1,219 \\
\hline & & Depois & 818 & 0,662 & 0,178 & 0,354 & 1,219 \\
\hline \multirow[t]{2}{*}{ RENT_CART } & Winrdoc_clascart & Antes & 810 & 0,122 & 0,032 & 0,067 & 0,193 \\
\hline & & Depois & 818 & 0,110 & 0,028 & 0,067 & 0,193 \\
\hline \multirow[t]{2}{*}{ ROE } & Wr_01_01_s & Antes & 810 & 0,314 & 0,222 & $-0,100$ & 0,702 \\
\hline & & Depois & 818 & 0,342 & 0,216 & $-0,100$ & 0,702 \\
\hline \multirow[t]{2}{*}{ REND_JR } & Wr_02_02_s & Antes & 810 & 0,305 & 0,151 & 0,132 & 0,654 \\
\hline & & Depois & 818 & 0,302 & 0,149 & 0,132 & 0,654 \\
\hline \multirow[t]{2}{*}{ RESULT_FIN } & Wlrsif & Antes & 809 & 6,463 & 1,041 & 3,187 & 7,482 \\
\hline & & Depois & 815 & 6,792 & 0,974 & 3,187 & 7,482 \\
\hline \multirow[t]{2}{*}{ RESULT_FIN_J } & Wlrsifj & Antes & 809 & 6,473 & 1,049 & 3,211 & 7,514 \\
\hline & & Depois & 815 & 6,814 & 0,969 & 3,211 & 7,514 \\
\hline \multirow[t]{2}{*}{ INAD } & Wlnpl & Antes & 803 & 4,724 & 1,484 & 1,024 & 6,363 \\
\hline & & Depois & 814 & 5,322 & 1,263 & 1,024 & 6,363 \\
\hline \multirow[t]{2}{*}{ TX_INAD } & Winad & Antes & 810 & 0,026 & 0,024 & 0,000 & 0,095 \\
\hline & & Depois & 818 & 0,027 & 0,021 & 0,000 & 0,095 \\
\hline LCAT & Wlcat & Antes & 810 & 8,770 & 1,316 & 4,821 & 9,975 \\
\hline \multirow{3}{*}{$\begin{array}{l}\text { Indicadores sociais } \\
\text { CLIEN }\end{array}$} & & Depois & 818 & 9,219 & 1,137 & 4,821 & 9,975 \\
\hline & Wsoma_cli_om ${ }^{1}$ & Antes & 810 & $3.808,86$ & $2.509,52$ & 202,00 & $7.020,00$ \\
\hline & & Depois & 818 & $4.748,15$ & $2.418,06$ & 202,00 & $7.020,00$ \\
\hline \multirow[t]{2}{*}{ OPER } & Wsoma_op_om ${ }^{2}$ & Antes & 810 & $6.698,78$ & $4.240,13$ & 278,00 & $12.447,00$ \\
\hline & & Depois & 818 & $8.457,46$ & $4.418,13$ & 278,00 & $12.447,00$ \\
\hline \multirow[t]{2}{*}{ ME_OPER } & Wme soma op om & Antes & 810 & 1,805 & 0,942 & 1,000 & 3,959 \\
\hline & & Depois & 818 & 1,646 & 0,747 & 1,000 & 3,959 \\
\hline \multirow[t]{2}{*}{ ME_CA } & Wme soma lca om & Antes & 810 & 0,002 & 0,002 & 0,000 & 0,019 \\
\hline & & Depois & 818 & 0,002 & 0,002 & 0,000 & 0,019 \\
\hline
\end{tabular}

A amostra compreende todas as cooperativas de crédito do Sistema Financeiro Nacional com informações disponibilizadas para o período de 2008 a 2014 , em semestres, totalizando 1.429 cooperativas observadas durante 14 semestres.

* Número de cooperativas multiplicado pelo número de períodos de tempo.

${ }^{1}$ Total de clientes ativos por modalidades: 1, 2, 3, 4 e submodalidades 1303 e 1304, 212 - empréstimos (microcrédito consumo) e 403 - financiamentos (microcrédito produtivo).

${ }^{2}$ Total de operações por modalidades: 1, 2, 3, 4 e submodalidades 1303 e 1304, 212 - empréstimos (microcrédito consumo) e 403 - financiamentos (microcrédito produtivo).

Nota 1: ROA: Retorno sobre Ativo; MARG_FIN: Margem de intermediação financeira; $M A R G \_O P$ : Margem operacional; CUST_OP: Custo operacional; RENT_CART: Rentabilidade da carteira de crédito; ROE: Retorno sobre o Patrimônio Líquido; REND_JR: Rendas de juros com operações de crédito em relação ao ativo total ajustado; RESULT_FIN: $\log$ do resultado da intermediação financeira; RESULT_FIN_J: log do resultado da intermediação financeira (considerando somente juros); INAD: log da inadimplência - Carteira em Risco $>90$ dias; TX_INAD: Taxa de inadimplência; LCAT: Log da carteira ativa; CLIEN: Total de clientes; OPER: Total de operações; $M E \_O P E R$ : Valor médio das operações; $M E \_C A$ : Carteira ativa média;

Nota 2: A variáveis RESULT_FIN, RESULT_FIN_J e INAD foram transformadas por logaritmo. 
Nota 3: Todas as variáveis foram winsorizadas a $10 \%$.

Nota 4: As variáveis nominais foram deflacionadas pelo IPCA (IBGE).

Nota 5: $L C A T$ é variável de controle.

Ao se comparar as médias das variáveis antes e após o evento observa-se que no grupo de tratamento o Retorno sobre o ativo (ROA), que reflete todas as operações da cooperativa, foi pouco afetado pelas mudanças. Sabe-se que a probabilidade de ele ser afetado por mudanças relacionadas especificamente ao microcrédito é pequena posto que, como visto, o microcrédito representa muito pouco em relação ao total de operações da cooperativa. Ainda assim, na média, o ROA aumentou após 201112 (de 6,5 para 6,7 pontos percentuais) provavelmente em função do substancial aumento na oferta de crédito. Já os indicadores margem de intermediação financeira $\left(M A R G_{-} F I N\right)$ e margem operacional (MARG_OP), em média, não sofreram variação; o custo operacional (CUST_OP) sofreu uma queda média de 1,3 pontos percentuais, contrariando as expectativas tendo em vista a redução das taxas de juros e aumento do número de operações. Entretanto, a rentabilidade da carteira (RENT_CART) diminuiu 1,2 pontos percentuais, em média, de acordo com o esperado. $\mathrm{O}$ retorno sobre o patrimônio líquido $(R O E)$ aumentou, em média, de 31,4 pontos percentuais para 34,2; a renda de juros (REND_JR), na média, praticamente manteve-se inalterada. Tanto o ROE como a REND_JR estão em desacordo com o esperado, todavia, como estes e os demais indicadores incluem todas as operações e não somente as de microcrédito, esse resultado pode ter decorrido de outros fatores que não as mudanças analisadas. O resultado da intermediação financeira (RESULT_FIN) e o resultado da intermediação financeira considerando somente juros (RESULT_FIN_J) aumentaram, em média, de 46,3 e 47,3 para 79,2 e 81,4 respectivamente, provavelmente em função do aumento da quantidade de operações. A inadimplência (INAD) aumentou, na média, de 4,724 para 5,322. Já a taxa de inadimplência $\left(T X \_I N A D\right)$ sofreu uma queda de 2,5 pontos percentuais.

No que tange aos indicadores sociais, o número de clientes (CLIEN) aumentou, em média, de 3.808,86 para 4.748,15; o número de operações (OPER) teve um aumento médio de 6.698 para 8.457; no que se refere aos indicadores médios, o número operações médias (MED_OPER), em média, caiu de 1,8 para 1,6. Significa que cada cliente possuía, em média, 1,8 contrato e reduziu para 1,6. Considerando a característica da progressividade dos empréstimos, o não crescimento dos valores médios pode indicar uma restrição na oferta deste tipo de crédito devido ao custo operacional elevado. Já a carteira ativa média $\left(M E \_C A\right)$ na média, não sofreu variação. 
Tabela 12: Estatística descritiva das variáveis antes e após as mudanças regulatórias no microcrédito (201112) - Grupo de Controle (Cooperativas que não fazem microcrédito)

\begin{tabular}{|c|c|c|c|c|c|c|c|}
\hline Nome da variável & Código da variável & Período & $\begin{array}{l}\mathrm{N}^{0} . \\
\text { Obs. }\end{array}$ & Média & $\begin{array}{l}\text { Desvio- } \\
\text { Padrão } \\
\end{array}$ & Min. & Max. \\
\hline \multicolumn{8}{|c|}{ Indicadores financeiros } \\
\hline \multirow[t]{2}{*}{ ROA } & Wr_01_05_s & Antes & 8.123 & 0,086 & 0,094 & $-0,036$ & 0,261 \\
\hline & & Depois & 7.255 & 0,098 & 0,092 & $-0,036$ & 0,261 \\
\hline \multirow[t]{2}{*}{ MARG_FIN } & $\mathrm{Wr}$ 03_19_s & Antes & 8.123 & 0,559 & 0,214 & 0,260 & 0,908 \\
\hline & & Depois & 7.255 & 0,561 & 0,208 & 0,260 & 0,908 \\
\hline \multirow[t]{2}{*}{ MARG_OP } & Wr_03_20_s & Antes & 8.123 & 0,184 & 0,190 & $-0,077$ & 0,521 \\
\hline & & Depois & 7.255 & 0,190 & 0,177 & $-0,077$ & 0,521 \\
\hline \multirow[t]{2}{*}{ CUST_OP } & Wd_1_1_00_0 & Antes & 8.124 & 0,729 & 0,275 & 0,354 & 1,219 \\
\hline & & Depois & 7.255 & 0,719 & 0,256 & 0,354 & 1,219 \\
\hline \multirow[t]{2}{*}{ RENT_CART } & Winrdoc_clascart & Antes & 8.124 & 0,128 & 0,040 & 0,067 & 0,193 \\
\hline & & Depois & 7.255 & 0,120 & 0,038 & 0,067 & 0,193 \\
\hline \multirow{2}{*}{ ROE } & Wr $0101 \mathrm{~s}$ & Antes & 8.124 & 0,247 & 0,244 & $-0,100$ & 0,702 \\
\hline & & Depois & 7.255 & 0,286 & 0,240 & $-0,100$ & 0,702 \\
\hline \multirow[t]{2}{*}{ REND_JR } & Wr_02_02_s & Antes & 8.124 & 0,350 & 0,174 & 0,132 & 0,654 \\
\hline & & Depois & 7.255 & 0,378 & 0,164 & 0,132 & 0,654 \\
\hline \multirow[t]{2}{*}{ RESULT_FIN } & Wlrsif & Antes & 7.916 & 5,073 & 1,299 & 3,187 & 7,482 \\
\hline & & Depois & 7.130 & 5,397 & 1,342 & 3,187 & 7,482 \\
\hline \multirow[t]{2}{*}{ RESULT_FIN_J } & Wlrsifj & Antes & 7.923 & 5,098 & 1,303 & 3,211 & 7,514 \\
\hline & & Depois & 7.135 & 5,416 & 1,344 & 3,211 & 7,514 \\
\hline \multirow[t]{2}{*}{ INAD } & Wlnpl & Antes & 6.917 & 3,444 & 1,638 & 1,024 & 6,363 \\
\hline & & Depois & 6.629 & 3,796 & 1,664 & 1,024 & 6,363 \\
\hline \multirow[t]{2}{*}{ TX_INAD } & Winad & Antes & 8.124 & 0,028 & 0,032 & 0,000 & 0,095 \\
\hline & & Depois & 7.255 & 0,027 & 0,028 & 0,000 & 0,095 \\
\hline LCAT & Wlcat & Antes & 8.124 & 7,136 & 1,554 & 4,821 & 9,975 \\
\hline \multirow{3}{*}{$\begin{array}{l}\text { Indicadores sociais } \\
\text { CLIEN }\end{array}$} & & Depois & 7.255 & 7,676 & 1,579 & 4,821 & 9,975 \\
\hline & Wsoma_cli_om ${ }^{1}$ & Antes & 8.117 & $1.588,84$ & $1.893,37$ & 202,00 & $7.020,00$ \\
\hline & & Depois & 7.249 & $1.870,75$ & $2.057,76$ & 202,00 & $7.020,00$ \\
\hline \multirow[t]{2}{*}{ OPER } & Wsoma_op_om ${ }^{2}$ & Antes & 8.117 & $2.956,07$ & $3.571,07$ & 278,00 & $12.447,00$ \\
\hline & & Depois & 7.249 & $3.050,81$ & $3.653,89$ & 278,00 & $12.447,00$ \\
\hline \multirow[t]{2}{*}{ ME_OPER } & Wme_soma_op_om & Antes & 8.117 & 1,800 & 1,092 & 1,000 & 3,959 \\
\hline & & Depois & 7.249 & 1,516 & 0,780 & 1,000 & 3,959 \\
\hline \multirow[t]{2}{*}{ ME_CA } & Wme_soma_lca_om & Antes & 8.117 & 0,007 & 0,006 & 0,007 & 0,019 \\
\hline & & Depois & 7.248 & 0,007 & 0,006 & 0,007 & 0,019 \\
\hline
\end{tabular}

A amostra compreende todas as cooperativas de crédito do Sistema Financeiro Nacional com informações disponibilizadas para o período de 2008 a 2014, em semestres, totalizando 1.429 cooperativas observadas durante 14 semestres.

* Número de cooperativas multiplicado pelo número de períodos de tempo.

1 Total de clientes ativos por modalidades: 1, 2, 3, 4 e submodalidades 1303 e 1304, 212 - empréstimos (microcrédito consumo) e 403 - financiamentos (microcrédito produtivo).

${ }^{2}$ Total de operações por modalidades: 1, 2, 3, 4 e submodalidades 1303 e 1304, 212 - empréstimos (microcrédito consumo) e 403 - financiamentos (microcrédito produtivo).

Nota 1: ROA: Retorno sobre Ativo; $M A R G_{-} F I N$ : Margem de intermediação financeira; $M A R G_{-} O P$ : Margem operacional; CUST_OP: Custo operacional; RENT_CART: Rentabilidade da carteira de crédito; ROE: Retorno sobre o Patrimônio Líquido; REND_JR: Rendas de juros com operações de crédito em relação ao ativo total ajustado; RESULT_FIN: $\log$ do resultado da intermediação financeira; RESULT_FIN_J: log do resultado da intermediação financeira (considerando somente juros); INAD: log da inadimplência - Carteira em Risco $>90$ dias; TX_INAD: Taxa de inadimplência; LCAT: Log da carteira ativa; CLIEN: Total de clientes; OPER: Total de operações; $M E \_O P E R$ : Valor médio das operações; $M E \_C A$ : Carteira ativa média;

Nota 2: A variáveis RESULT_FIN, RESULT_FIN_J e IN $A D$ foram transformadas por logaritmo.

Nota 3: Todas as variáveis foram winsorizadas a $10 \%$.

Nota 4: As variáveis nominais foram deflacionadas pelo IPCA (IBGE).

Quanto comparadas as médias do grupo de controle antes e após o evento, obteve-se os seguintes resultados: nos indicadores financeiros o Retorno sobre o ativo $(R O A)$, na média, subiu de 8,6 para 9,8 pontos percentuais e, além disso, foi maior que o $R O A$ do grupo de tratamento, indicando que nas cooperativas que ofertam microcrédito, o resultado foi pior; a 
margem de intermediação financeira $\left(M A R G_{-} F I N\right)$, do mesmo modo que no grupo de tratamento, na média, não sofreu variação sendo maior para este grupo do que para o outro; a margem operacional (MARG_OP) do grupo de controle, em média, sofreu uma variação positiva de 0,6 pontos percentuais e, do mesmo modo que a margem, é também maior para este grupo; o custo operacional (CUST_OP) do grupo de controle, em média, não sofreu variação sendo que no grupo de tratamento ele diminuiu, indo de encontro ao esperado e aos pressupostos teóricos discutidos - de acordo com a literatura analisada, o microcrédito tem um custo operacional maior que o das demais modalidades de crédito em decorrência do acompanhamento das operações pelos agentes de crédito; a rentabilidade da carteira (RENT_CAR) do grupo de controle caiu 0,8 pontos percentuais durante o período analisado sendo que no grupo de tratamento essa redução foi na ordem de 1,2 pontos percentuais, em média. O comportamento deste indicador está de acordo com o esperado, tendo em vista que a redução da taxa de juros aumenta o custo da operação de crédito podendo contribuir para a redução da rentabilidade; o retorno sobre o patrimônio líquido $(R O E)$ do grupo de controle aumentou em 3,9 pontos percentuais sendo que no grupo de tratamento esse aumento foi menor (2,8 pontos percentuais) sinalizando para um efeito negativo das mudanças regulatórias analisadas. O ROE mede a receita gerada em relação ao capital integralizado pelos cooperados. Para as cooperativas que ofertaram microcrédito, durante o período analisado, esse retorno é maior (31,4 e 34,2 pontos percentuais antes e depois do evento, respectivamente contra 24,7 e 28,6 do grupo de controle, sugerindo que o cooperado foi duplamente beneficiado: obtendo o crédito e também recebendo maiores rendimentos por meio do $R O E$; A renda de juros $\left(R E N D \_J R\right)$ do grupo de controle aumentou em 2,8 pontos percentuais, em média. No grupo de tratamento, houve uma leve queda, o que era esperado. Além das taxas de juros das operações de microcrédito serem menores do que a das demais modalidades, com a implementação do Programa Crescer, elas baixaram ainda mais. Mesmo as instituições não mandatárias, caso das cooperativas de crédito aqui em estudo, se viram forças a baixarem as suas taxas em função da concorrência com os bancos públicos; o entanto, o resultado da intermediação financeira (RESULT_FIN) e o resultado da intermediação financeira considerando somente juros (RESULT_FIN_J) do grupo de controle, em média, cresceram de 5,073 para 5,397 e de 5,098 para 5,416 respectivamente. No grupo de tratamento essas margens também cresceram - de 6,463 para 6,792 e de 6,473 para 6,814 respectivamente, em média. As margens do grupo de controle, em média, são maiores que as do grupo de tratamento, provavelmente em função de as cooperativas deste grupo praticarem taxas de juros mais elevadas e operarem maiores volumes de empréstimos; a inadimplência 
(INAD) - valores vencidos há mais de 90 dias - do grupo de controle, houve um crescimento, em média, de 3,444 para 3,796. No grupo de tratamento, a inadimplência (INAD) aumentou, na média, de 4,724 para 5,322. indo de encontro aos pressupostos teóricos e estudos empíricos acerca das microfinanças ao afirmarem que, em função do aval solidário e do acompanhamento pelo agente de crédito, a inadimplência das operações de microcrédito é menor do que das demais operações de crédito. Isso pode ser resultante do considerável crescimento do número de operações e de clientes na modalidade microcrédito; já a taxa de inadimplência (TX_INAD), durante o período analisado, em média, não sofreu variação. No entanto, no grupo de tratamento, houve uma de queda de 2,5 pontos percentuais em conformidade com a literatura.

No que se refere aos indicadores sociais, o número de clientes (CLIEN), na média, aumentou de 1.588 para 1.870 indicando um crescimento de menos de $18 \%$ sendo que no grupo de tratamento, esse crescimento foi de $24,7 \%$. Significa que houve, de fato, uma massificação da oferta de microcrédito pelas cooperativas de crédito; o total de operações $(O P E R)$ do grupo de controle cresceu, em média, aproximadamente 3,18\% (de 2.956 para 3.050). Já no grupo de tratamento, o total de operações em geral, incluindo o microcrédito, cresceu 26,3\%; o número médio de operações (ME_OPER) do grupo de controle passou de 1,8 para 1,5 , em média. Significa que a taxa de renovação dos contratos caiu para este grupo não se distanciando muito do grupo de tratamento que teve uma queda de 1,8 para 1,6 no número médio de operações durante o período; por fim, a carteira ativa média $\left(M E \_C A\right)$, em média, não sofreu variação em nenhum dos dois grupos.

Destarte, uma vez concluída a análise das estatísticas descritivas, o passo seguinte foi a estimação das variáveis proxies dos indicadores de desempenho financeiro e social das cooperativas de crédito. Estes indicadores foram testados em um modelo de diferenças em diferenças apresentado no Capítulo III. Os testes foram realizados com a população de cooperativas de crédito existentes no Brasil ao longo do período de 2008 a 2014, as quais totalizam 1.429 cooperativas observadas durante 14 semestres. Para atender ao objetivo da pesquisa, foram criadas as dummies de grupo (igual a 1 se a cooperativa oferta microcrédito) e de tempo (igual a 1 para o período após 2011), além do termo de interação (igual a 1) se a cooperativa oferta microcrédito após 2011. As variáveis dependentes são os indicadores financeiros e sociais já apresentados, e as variáveis independentes são as dummies de grupo, de tempo, de direcionamento produtivo e de interação: $M C, T D, D I R$ e $M C D I R$, respectivamente, além das variáveis de controle: LCAT (log da carteira ativa total) e DTDMC (interação entre as dummies de tempo - TD e as dummies de grupo - MC). 
Se as mudanças regulatórias ocorridas no microcrédito após 2011 afetam o desempenho financeiro e social das cooperativas de crédito, os indicadores analisados no presente estudo sofrem os efeitos das mudanças de regras. Assim, espera-se que os indicadores do grupo de tratamento sejam mais afetados que os do grupo de controle. Presume-se, ainda, que os indicadores financeiros do grupo de tratamento (cooperativas que ofertam microcrédito) sejam negativamente impactados assim como os indicadores sociais sejam positivamente influenciados.

Essas hipóteses fundamentam-se na abordagem da Nova Economia Institucional, a qual, além de defender a intervenção nos mercados a fim de mitigar os efeitos das imperfeições que lhes são inerentes, dando suporte a intervenções como o PNMPO e o programa CRESCER - considerado uma expansão do PNMPO -, ressaltam a necessidade de sustentabilidade das instituições financeiras no longo prazo.

\subsubsection{Desempenho financeiro}

Os indicadores de desempenho financeiros testados no presente estudo estão classificados em três grupos: Qualidade dos Ativos, Eficiência e Rentabilidade. A qualidade dos ativos é mensurada por meio da inadimplência (carteira em risco $>90$ dias), que reporta o risco dos empréstimos em atraso (Bruett et al., 2002) e da rentabilidade da carteira, a qual mensura o quanto a instituição recebeu de juros e multas pelos empréstimos. Considerou-se, ainda neste grupo, o resultado da intermediação financeira.

No que concerne à Eficiência, a qual mede a capacidade de uma IMF fornecer seus produtos e serviços ao menor custo possível (Bruett et al., 2002), os indicadores testados são margem operacional e custo operacional.

O terceiro e último grupo de indicadores analisados no presente estudo refere-se à rentabilidade também denominada lucratividade. Os indicadores deste grupo são o $R O A$ e o $R O E$. O primeiro indica o quanto os acionistas auferem de lucro para cada unidade monetária de recursos próprios investidos na empresa (Assaf Neto, 2010) - no caso das cooperativas, o quanto os cooperados auferem de retorno para cada unidade monetária de capital social integralizado - e o segundo mede a capacidade de geração de receita. Em síntese, o ROA indica o quanto a empresa obtém de lucro para cada unidade monetária de investimento total. A interpretação é quanto maior, melhor. A Margem operacional, definida como resultado operacional dividido pela receita líquida, representa o resultado operacional em percentual. 
A rentabilidade, em resumo, reflete a capacidade de autofinanciamento da instituição e indica o percentual de retorno obtido sobre o capital investido, ou seja, a remuneração do patrimônio líquido.

Tomando esses indicadores como variáveis dependentes, estima-se regressões com dados em painel desbalanceado, efeito fixo. A primeira estimação é feita com os indicadores de desempenho financeiro, os quais estão especificados no Capítulo III. Os resultados são apresentados na Tabela 13.

Tabela 13: Regressões sem controles - Indicadores Financeiros

\begin{tabular}{|c|c|c|c|c|c|c|c|}
\hline $\begin{array}{l}\text { Nome da } \\
\text { variável }\end{array}$ & $\begin{array}{c}\text { Código da } \\
\text { variável }\end{array}$ & $\begin{array}{c}\mathbf{N}^{\mathbf{0}} \text { de } \\
\text { observ. }\end{array}$ & $\begin{array}{l}\mathbf{N}^{0} \text { de } \\
\text { Coop. }\end{array}$ & $\begin{array}{c}\text { Coef. } \\
M C D I R\end{array}$ & Sig $(P>|t|)$ & $\begin{array}{c}\text { Sinal } \\
\text { esperado }\end{array}$ & $\begin{array}{c}\text { Sinal } \\
\text { encontra } \\
\text { do }\end{array}$ \\
\hline \multicolumn{8}{|c|}{ Qualidade dos ativos } \\
\hline INAD & Wlnpl & 15.163 & 1.362 & 0,134 & $0,051 *$ & $(-)$ & $(+)$ \\
\hline MARG_FIN & Wr_03_19_s & 17.006 & 1.429 & 0,001 & 0,803 & $(-)$ & () \\
\hline REND_JR & $\mathrm{Wr} \_02-02 \_\mathrm{s}$ & 17.007 & 1.429 & $-0,035$ & $0,000 * * *$ & $(-)$ & $(-)$ \\
\hline RENT_CART & Winrdoc_cl t & 17.007 & 1.429 & $-0,005$ & $0,000 * * *$ & $(-)$ & $(-)$ \\
\hline RESULT_FIN & Wlrsif & 16.670 & 1.421 & 0,043 & 0,236 & $(-)$ & () \\
\hline RESULT_FIN_J & Wlrsifj & 16.682 & 1.421 & 0,056 & 0,124 & $(-)$ & ( ) \\
\hline TX_INAD & Winad & 17.007 & 1.429 & 0,001 & 0,623 & $(-)$ & ( ) \\
\hline \multicolumn{8}{|l|}{ Rentabilidade } \\
\hline $\mathrm{ROA}$ & Wr_01_05_s & 17.006 & 1.429 & $-0,003$ & 0,386 & $(-)$ & ( ) \\
\hline ROE & Wr_01_01_s & 17.007 & 1.429 & 0,002 & 0,881 & $(-)$ & ( ) \\
\hline \multicolumn{8}{|l|}{ Eficiência } \\
\hline CUST_OP & Wd_1_1_00_0 & 17.007 & 1.429 & $-0,024$ & $0,005 * *$ & $(+)$ & $(-)$ \\
\hline MARG_OP & $\mathrm{Wr} 0320 \_\mathrm{s}$ & 17.006 & 1.429 & 0,023 & $0,000 * * *$ & $(-)$ & $(+)$ \\
\hline
\end{tabular}

Nota 1: INAD: inadimplência - carteira em risco > 90 dias; MARG_FIN: margem de intermediação financeira; $R E N D \_J R$ : rendas de juros com operações de crédito em relação ao ativo total ajustado; RENT_CART: rentabilidade da carteira de crédito; RESULT FIN: resultado da intermediação financeira; RESULT_FIN J: resultado da intermediação financeira, considerando somente juros; TX_INAD: taxa de inadimplência; $R O \overline{O A}$ : retorno sobre ativo; ROE: retorno sobre o patrimônio líquido; CUST_OP: custo operacional; MARG_OP: margem operacional.

Nota 2: RESULT_FIN, RESULT_FIN_J e INAD foram transformadas por logaritmo.

Nota 3: Todas as variáveis foram winsorizadas a $10 \%$.

Nota 4: As equações são estimadas pelo modelo de regressão com dados em painel desbalanceado efeitos fixos, com erros padrões robustos.

Nota 5: $(*)$ coeficiente estimado para a variável significativo a $10 \%$; $(* *)$ coeficiente estimado para a variável significativo a $5 \% ;(* * *)$ coeficiente estimado para a variável significativo a $1 \%$.

Nota 6: As variáveis nominais foram deflacionadas pelo IPCA (IBGE).

A Tabela 13 mostra que, no nível de significância de 1\%, são estatisticamente significantes os coeficientes estimados das variáveis: rendas de juros com operações de crédito em relação ao ativo total ajustado $\left(R E N D \_J R\right.$, rentabilidade da carteira de crédito (RENT_CART), e margem operacional $\left(M A R G_{-} O P\right)$,). Ao nível de 5\% de significância, o custo operacional (CUST_OP) e; a 10\%, inadimplência (INAD). O custo operacional (CUST_OP) diminuiu quando esperava-se um aumento, e a margem operacional (MARG_OP) aumentou quando esperava-se uma redução. Os sinais dos coeficientes das demais variáveis analisadas estão conforme o esperado. 
Em relação à magnitude dos coeficientes estimados, considerando que o coeficiente estimado MCDIR captura a "diferença das diferenças", ou seja, o quanto mudou a diferença das médias da variável de resposta depois do evento, pode-se afirmar que a diferença média da inadimplência $(I N A D)$ aumentou em 0,134 quando se esperava uma redução; a diferença da variável rendas de juros com operações de crédito $\left(R E N D \_J R\right)$ média entre os grupos diminuiu 3,5 pontos percentuais; a diferença da rentabilidade da carteira (RENT_CART) média entre os grupos diminuiu 0,5 ponto percentual após o evento; a diferença média do custo operacional (CUST_OP) entre os grupos diminuiu 2,4 pontos percentuais após o evento e; a diferença média da margem operacional $\left(M A R G_{-} O P\right)$ entre os grupos aumentou 2,3 pontos percentuais depois do evento.

A fim de melhorar a plausibilidade dos resultados, fez-se uma nova estimativa, incluindo o total da carteira ativa ( $L C A T)$, em logaritmo, como variável de controle. Os resultados estão na Tabela 14.

Tabela 14: Regressões controlando pela carteira ativa total (LCAT) - Indicadores Financeiros

\begin{tabular}{|c|c|c|c|c|c|c|c|}
\hline $\begin{array}{c}\text { Nome da } \\
\text { variável }\end{array}$ & $\begin{array}{c}\text { Código da } \\
\text { variável } \\
\end{array}$ & $\begin{array}{c}\mathbf{N}^{0} \text { de } \\
\text { observ }\end{array}$ & $\begin{array}{l}\mathrm{N}^{0} \text { de } \\
\text { Coop }\end{array}$ & $\begin{array}{c}\text { Coef. } \\
\text { MCDIR }\end{array}$ & Sig $(P>|t|)$ & $\begin{array}{c}\text { Sinal } \\
\text { esperado }\end{array}$ & $\begin{array}{c}\text { Sinal } \\
\text { encontrado }\end{array}$ \\
\hline \multicolumn{8}{|c|}{ Qualidade dos Ativos } \\
\hline INAD & Wlnpl & 15.163 & 1.362 & 0,089 & 0,175 & $(-)$ & ( ) \\
\hline MARG_FIN & Wr_03_19_s & 17.006 & 1.429 & 0,002 & 0,753 & $(-)$ & ( ) \\
\hline REND_JR & $\mathrm{Wr} \_02-02-\mathrm{s}$ & 17.007 & 1.429 & $-0,037$ & $0,000 * * *$ & $(-)$ & $(-)$ \\
\hline RENT_CART & Winrdoc_cl- $\bar{c}$ t & 17.007 & 1.429 & $-0,005$ & $0,000 * * *$ & $(-)$ & $(-)$ \\
\hline RESUL̄T_FIN & Whlrsif & 16.670 & 1.421 & 0,013 & 0,663 & $(-)$ & ( ) \\
\hline RESULT_FIN_J & Wlrsifj & 16.682 & 1.421 & 0,026 & 0,400 & $(-)$ & ( ) \\
\hline TX_INAD & Winad & 17.007 & 1.429 & 0,001 & 0,411 & $(-)$ & ( ) \\
\hline \multicolumn{8}{|l|}{ Rentabilidade } \\
\hline ROA & Wr_01_05_s & 17.006 & 1.429 & $-0,003$ & 0,300 & $(-)$ & ( ) \\
\hline ROE & Wr_01_01_s & 17.007 & 1.429 & $-0,000$ & 0,974 & $(-)$ & ( ) \\
\hline \multicolumn{8}{|l|}{ Eficiência } \\
\hline CUST_OP & Wd_1_1_00_0 & 17.007 & 1.429 & $-0,021$ & $0,018 * *$ & $(+)$ & $(-)$ \\
\hline MARG_OP & $\mathrm{Wr}=320-\mathrm{s}$ & 17.006 & 1.429 & 0,022 & $0,000 * * *$ & $(-)$ & $(+)$ \\
\hline
\end{tabular}

Nota 1: INAD: inadimplência - carteira em risco > 90 dias; MARG FIN: margem de intermediação financeira; REND JR: rendas de juros com operações de crédito em relação ao ativo total ajustado; RENT_CART: rentabilidade da carteira de crédito; RESULT FIN: resultado da intermediação financeira; RESULT_FIN J: resultado da intermediação financeira, considerando somente juros; TX INAD: taxa de inadimplência; $R O \overline{O A}$ : retorno sobre ativo; ROE: retorno sobre o patrimônio líquido; CUST_OP: custo operacional; MARG_OP: margem operacional.

Nota 2: RESULT_FIN, RESULT_FIN_J e INAD foram transformadas por logaritmo.

Nota 3: Todas as variáveis foram winsorizadas a $10 \%$.

Nota 4: As equações são estimadas pelo modelo de regressão com dados em painel desbalanceado efeitos fixos, com erros padrões robustos.

Nota 5: $\left(^{*}\right)$ coeficiente estimado para a variável significativo a $10 \% ;(* *)$ coeficiente estimado para a variável significativo a $5 \% ;(* * *)$ coeficiente estimado para a variável significativo a $1 \%$.

Nota 6: As variáveis nominais foram deflacionadas pelo IPCA (IBGE).

Como indica a Tabela 14, no nível de significância de 1\%, são estatisticamente significantes os coeficientes estimados das variáveis: rendas de juros (REND_JR), 
rentabilidade da carteira $\left(R E N T \_C A R T\right)$ e margem operacional $\left(M A R G \_O P\right)$. O coeficiente estimado da variável custo operacional (CUST_OP) continuou significante, porém ao nível de $5 \%$, O coeficiente estimado da variável inadimplência $(I N A D)$ perdeu significância após inclusão da variável de controle carteira ativa (LCAT). Em relação aos sinais esperados, ocorreu o mesmo que na estimação anterior, com os coeficientes estimados das variáveis margem operacional $\left(M A R G_{-} O P\right)$ e custo operacional (CUST_OP) apresentando sinal contrário ao esperado.

No que se refere à magnitude dos coeficientes estimados, ocorre situação semelhante àquela da estimação sem controles, a saber: a diferença da variável rendas de juros $\left(R E N D \_J R\right)$ média entre os grupos diminuiu 3,7 pontos percentuais; a diferença da rentabilidade da carteira ( $R E N T$ _CART) média entre os grupos diminuiu 0,5 ponto percentual; a diferença média do custo operacional (CUST_OP) entre os grupos diminuiu 2,1 pontos percentuais e; a diferença da margem operacional (MARG_OP) média entre os grupos aumentou 2,2 pontos percentuais depois do evento.

Outro tipo de estimativa realizada foi a regressão controlando pela interação entre a carteira ativa total (LCAT) e as dummies de tempo. Os achados encontram-se na Tabela 15.

Tabela 15: Regressões controlando pela interação entre a carteira ativa total (LCAT) e as dummies de tempo Indicadores Financeiros

\begin{tabular}{|c|c|c|c|c|c|c|c|}
\hline $\begin{array}{c}\text { Nome da } \\
\text { variável }\end{array}$ & $\begin{array}{c}\text { Código da } \\
\text { variável }\end{array}$ & $\begin{array}{c}\mathrm{N}^{0} \mathrm{de} \\
\text { observ }\end{array}$ & $\begin{array}{l}N^{0} \text { de } \\
\text { Coop }\end{array}$ & $\begin{array}{c}\text { Coef. } \\
\text { MCDIR }\end{array}$ & $\operatorname{Sig}(P>|t|)$ & $\begin{array}{c}\text { Sinal } \\
\text { esperado }\end{array}$ & $\begin{array}{c}\text { Sinal } \\
\text { encontrado }\end{array}$ \\
\hline \multicolumn{8}{|c|}{ Qualidade dos Ativos } \\
\hline INAD & Wlnpl & 15.163 & 1.362 & 0,009 & 0,891 & $(-)$ & ( ) \\
\hline MARG_FIN & Wr_03_19_s & 17.006 & 1.429 & 0,003 & 0,646 & $(-)$ & ( ) \\
\hline REND_JR & $\mathrm{Wr} \_02 \_02-\mathrm{s}$ & 17.007 & 1.429 & $-0,013$ & $0,065 *$ & $(-)$ & $(-)$ \\
\hline RENT_CART & Winrdoc_cl t & 17.007 & 1.429 & $-0,002$ & 0,205 & $(-)$ & ( ) \\
\hline RESUL̄T_FIN & Wlrsif & 16.670 & 1.421 & $-0,048$ & 0,170 & $(-)$ & ( ) \\
\hline RESULT_FIN_J & Wlrsifj & 16.682 & 1.421 & $-0,036$ & 0,294 & $(-)$ & ( ) \\
\hline TX_INAD & Winad & 17.007 & 1.429 & 0,000 & 0,678 & $(-)$ & ( ) \\
\hline \multicolumn{8}{|l|}{ Rentabilidade } \\
\hline $\mathrm{ROA}$ & Wr_01_05_s & 17.006 & 1.429 & $-0,003$ & 0,441 & $(-)$ & ( ) \\
\hline ROE & Wr_01_01_s & 17.007 & 1.429 & $-0,004$ & 0,799 & $(-)$ & ( ) \\
\hline \multicolumn{8}{|l|}{ Eficiência } \\
\hline CUST_OP & Wd_1_1_00_0 & 17.007 & 1.429 & $-0,001$ & 0,910 & $(+)$ & ( ) \\
\hline MARG_OP & $\mathrm{Wr} 0320 \mathrm{~s}$ & 17.006 & 1.429 & 0,006 & 0,237 & $(-)$ & ( ) \\
\hline
\end{tabular}

Nota 1: INAD: inadimplência - carteira em risco > 90 dias; MARG_FIN: margem de intermediação financeira; $R E N D \_J R$ : rendas de juros com operações de crédito em relação ao ativo total ajustado; RENT_CART: rentabilidade da carteira de crédito; RESULT_FIN: resultado da intermediação financeira; RESULT_FIN_J: resultado da intermediação financeira, considerando somente juros; $T X \_I N A D$ : taxa de inadimplência; $R O \bar{O} A$ : retorno sobre ativo; ROE: retorno sobre o patrimônio líquido; CUST_OP: custo operacional; MARG_OP: margem operacional.

Nota 2: RESULT_FIN, RESULT_FIN_J e INAD foram transformadas por logaritmo.

Nota 3: Todas as variáveis foram winsorizadas a $10 \%$.

Nota 4: As equações são estimadas pelo modelo de regressão com dados em painel desbalanceado efeitos fixos, com erros padrões robustos.

Nota 5: $(*)$ coeficiente estimado para a variável significativo a $10 \% ;(* *)$ coeficiente estimado para a variável significativo a $5 \% ;(* * *)$ coeficiente estimado para a variável significativo a $1 \%$. 
Nota 6: As variáveis nominais foram deflacionadas pelo IPCA (IBGE).

Como evidencia a Tabela 15, usando um controle mais rígido, a saber, a interação entre a carteira ativa total $(C A T)$ e as variáveis de tempo, o que dá mais robustez aos resultados, somente continuou significativo o coeficiente estimado da variável rendas de juros com operações de crédito $\left(R E N D \_J R\right)$, a $10 \%$ de significância. Quanto ao sinal, está de acordo com o esperado. Em relação à magnitude dos coeficientes estimados, a diferença da diferença média da renda de juros (REND_JR) entre os grupos diminuiu 1,3 ponto percentual após as mudanças.

Por fim, fez-se ainda um outro tipo de estimação por meio da interação entre a variável dummy de grupo $M C$ e as dummies de tempo $T D$. Como esse controle é muito rígido, nenhum o coeficiente estimado se apresentou estatisticamente significante.

Resumidamente, após estimar as regressões com todos os controles, é possível depreender que apenas o coeficiente estimado de uma única variável mostrou significância estatística, a saber, rendas de juros com operações de crédito $\left(R E N D \_J R\right)$, a $10 \%$ de significância. Portanto, os resultados sinalizam para um impacto pouco claro das mudanças de regras do microcrédito no desempenho financeiro das cooperativas de crédito.

Logo, dentre as variáveis proxies representativas dos grupos de indicadores financeiros analisados por este estudo, os resultados sugerem que, nas estimações sem controle e com controle menos rígido, podem ter sido influenciadas pelas mudanças regulatórias do microcrédito as seguintes:

○ Qualidade dos Ativos: inadimplência $(I N A D)$, rendas de juros com operações de crédito $\left(R E N D \_J R\right)$, rentabilidade da carteira de crédito (RENT_CAR

○ Eficiência: custo operacional (CUST_OP) e margem operacional $\left(M A R G_{-} O P\right)$, ou seja, todas as variáveis deste grupo;

○ Rentabilidade: nenhuma variável deste grupo foi significativa estatisticamente.

O grupo de indicadores denominado Eficiência, abordado neste estudo na perspectiva de Bruett et al. (2002), ou seja, como a capacidade de uma IMF ofertar produtos e serviços ao menor custo possível, apresentou resultados mais coerentes com a missão e prática das cooperativas de crédito. Dada a natureza deste tipo de instituição, a qualidade dos ativos e a rentabilidade não são tão importantes para o cumprimento da sua dupla missão quanto o são a Eficiência. 


\subsubsection{Desempenho social}

Como discutido no Capítulo II, as cooperativas de crédito são o tipo de IMF que mais representa o caráter dual atribuído às IMFs em geral, isto é, combinam objetivos econômicofinanceiros e sociais, com ênfase nestes últimos. Grande parte dos estudos acerca do desempenho social de IMFs discutem um possível trade-off entre a busca de alcance social e a sustentabilidade das instituições.

Esta pesquisa considera desempenho social como a concessão de microcrédito ao maior número possível de pessoas (alcance do microcrédito) e o mensura com base em duas dimensões: profundidade do alcance e amplitude do alcance (Conning, 1999). Por profundidade do alcance, compreende-se o atendimento às pessoas mais pobres, e a amplitude significa servir a um grande número de pessoas, mesmo que elas não sejam os "mais pobres dos pobres" ou extremamente pobres (Brau \& Woller, 2004; Schreiner, 2002). As variáveis utilizadas para medir estas duas dimensões são as que seguem:

Para a amplitude do alcance: total de empréstimos e número de clientes atendidos ou mutuários ativos (Barry \& Tacneng, 2014; Bassem, 2009; Cull et al., 2007; Hartarska, 2005; Hartarska \& Mersland, 2012; Hartarska \& Nadolnyak, 2007; Mersland \& Strøm, 2009; Meyer, 2002; Navajas et al., 2000; Quayes, 2012; Rosenberg, 2009). Para a profundidade do alcance: valor médio dos empréstimos (Barry \& Tacneng, 2014; Hartarska \& Nadolnyak, 2007; Kar, 2010; Luzzi \& Weber, 2006; Luzzi \& Weber, 2007; Mersland \& Strøm, 2009; Quayes, 2012) e valor médio das operações.

Assim, por meio de regressões com dados em painel desbalanceado, efeito fixo, estimaram-se os modelos com as variáveis proxies dos indicadores de desempenho social, inicialmente sem controles, cujos resultados estão na Tabela 16.

Tabela 16: Regressões sem controles - Indicadores sociais

\begin{tabular}{|c|c|c|c|c|c|c|c|}
\hline Nome da variável & Código da variável & $\begin{array}{c}\mathbf{N}^{\mathbf{0}} \text { de } \\
\text { observ }\end{array}$ & $\begin{array}{l}\mathrm{N}^{0} \text { de } \\
\text { Coop }\end{array}$ & $\begin{array}{c}\text { Coef. } \\
M C D I R\end{array}$ & Sig $(\mathbf{P}>|\mathbf{t}|)$ & $\begin{array}{c}\text { Sinal } \\
\text { esperado }\end{array}$ & $\begin{array}{c}\text { Sinal } \\
\text { encontrado }\end{array}$ \\
\hline \multicolumn{8}{|c|}{ Amplitude do alcance } \\
\hline CLIEN & Wsoma_cli_om ${ }^{1}$ & 16.994 & 1.429 & 716,20 & $0,000 * * *$ & $(+)$ & $(+)$ \\
\hline OPER & Wsoma_op_om ${ }^{2}$ & 16.994 & 1.429 & $1.820,05$ & $0,000 * * *$ & $(+)$ & $(+)$ \\
\hline \multicolumn{8}{|c|}{ Profundidade do alcance } \\
\hline $\mathrm{ME} \mathrm{CA}$ & Wme soma lca om & 16.993 & 1.429 & $-0,001$ & $0,000 * * *$ & $(-)$ & $(-)$ \\
\hline ME OPER & Wme soma op om & 16.994 & 1.429 & 0,055 & $0,007 * * *$ & $(-)$ & $(+)$ \\
\hline
\end{tabular}

Total de clientes ativos por modalidades: 1, 2, 3, 4 e submodalidades 1303 e 1304, 212 - empréstimo (microcrédito consumo) e 403 - financiamento (microcrédito produtivo).

${ }^{2}$ Total de operações por modalidades: 1, 2, 3, 4 e submodalidades 1303 e 1304, 212 - empréstimo (microcrédito consumo) e 403 - financiamento (microcrédito produtivo).

Nota 1: CLIEN: Total de clientes; OPER: Total de operações; ME_CA: Carteira ativa média; ME_OPER: Valor médio das operações.

Nota 2: Todas as variáveis foram winsorizadas a $10 \%$. 
Nota 3: As equações são estimadas pelo modelo de regressão com dados em painel desbalanceado efeitos fixos, com erros padrões robustos.

Nota 4: $(*)$ coeficiente estimado para a variável significativo a $10 \%$; $(* *)$ coeficiente estimado para a variável significativo a $5 \% ;(* * *)$ coeficiente estimado para a variável significativo a $1 \%$.

Nota 5: As variáveis nominais foram deflacionadas pelo IPCA (IBGE).

Como mostra a Tabela 16, no nível de significância de 1\%, foram estatisticamente significantes os coeficientes estimados das variáveis: total de clientes (CLIEN), total de operações $(O P E R)$, carteira ativa média $\left(M E_{-} C A\right)$ ou valor médio dos empréstimos e valor médio das operações $\left(M E \_O P E R\right)$, ou seja, todas os indicadores sociais, tanto os representativos da dimensão amplitude do alcance quanto da profundidade do alcance. Em relação ao sinal esperado, com exceção do coeficiente estimado da variável operações médias $\left(M E \_O P E R\right)$, que apresentou sinal contrário ao esperado, todos os demais coeficientes estimados estão em conformidade com as expectativas.

Sobre a magnitude dos coeficientes estimados, dentre as variáveis representativas da dimensão amplitude do alcance, a diferença média no total de clientes (CLIEN) entre os grupos foi 716 e a diferença média no total de operações $(O P E R)$ foi 1.820. Relativamente à profundidade do alcance, a diferença média do coeficiente estimado da variável valor médio dos empréstimos ou carteira ativa média $\left(M E_{-} C A\right)$ diminuiu 0,1 ponto percentual entre os grupos, conforme o esperado e sinalizado pela literatura indicando que mais clientes pobres foram comtemplados ainda que em pequena magnitude. Nesta estimação, o coeficiente estimado da variável $M E \_O P E R$ (média das operações) aumentou 5,5 pontos percentuais entre os grupos, ao contrário do esperado, apontando para uma maior concentração da quantidade de contratos por cliente.

A fim de melhorar as análises, da mesma maneira que ocorreu com as estimações dos coeficientes das variáveis/indicadores financeiros, realizou-se outro tipo de estimação incluindo no modelo variável carteira ativa total $(C A T)$ como variável de controle. Os resultados estão apresentados na Tabela 17

Tabela 17: Regressões controlando pela carteira ativa total (LCAT) - Indicadores sociais

\begin{tabular}{|c|c|c|c|c|c|c|c|}
\hline Nome da variável & Código da variável & $\begin{array}{c}\mathbf{N}^{0} \text { de } \\
\text { observ. }\end{array}$ & $\begin{array}{l}\mathrm{N}^{0} \text { de } \\
\text { Coop. }\end{array}$ & $\begin{array}{c}\text { Coef. } \\
M C D I R\end{array}$ & $\begin{array}{c}\text { Sig } \\
(\mathbf{P}>|\mathbf{t}|)\end{array}$ & $\begin{array}{c}\text { Sinal } \\
\text { esperado }\end{array}$ & $\begin{array}{c}\text { Sinal } \\
\text { encontrad } \\
0 \\
\end{array}$ \\
\hline \multicolumn{8}{|c|}{ Amplitude do alcance } \\
\hline CLIEN & Wsoma_cli_om ${ }^{1}$ & 16.994 & 1.429 & 697,67 & $0,000 * * *$ & $(+)$ & $(+)$ \\
\hline OPER & Wsoma_op_om ${ }^{2}$ & 16.994 & 1.429 & $1.743,50$ & $0,000 * * *$ & $(+)$ & $(+)$ \\
\hline \multicolumn{8}{|c|}{ Profundidade do alcance } \\
\hline ME_CA & Wme_soma_lca_om & 16.993 & 1.429 & $-0,000$ & $0,000 * * *$ & $(-)$ & $(-)$ \\
\hline ME_OPER & Wme_soma_op_om & 16.994 & 1.429 & 0,043 & $0,030 * *$ & $(-)$ & $(+)$ \\
\hline
\end{tabular}

Total de clientes ativos por modalidades: 1, 2, 3, 4 e submodalidades 1303 e 1304, 212 - empréstimo (microcrédito consumo) e 403 - financiamento (microcrédito produtivo). 
${ }^{2}$ Total de operações por modalidades: 1, 2, 3, 4 e submodalidades 1303 e 1304, 212 - empréstimo (microcrédito consumo) e 403 - financiamento (microcrédito produtivo).

Nota 1: CLIEN: Total de clientes; OPER: Total de operações; $M E \_C A$ : Carteira ativa média; ME_OPER: Valor médio das operações.

Nota 2: Todas as variáveis foram winsorizadas a $10 \%$.

Nota 3: As equações são estimadas pelo modelo de regressão com dados em painel desbalanceado efeitos fixos, com erros padrões robustos.

Nota 4: $(*)$ coeficiente estimado para a variável significativo a $10 \% ;(* *)$ coeficiente estimado para a variável significativo a $5 \% ;(* * *)$ coeficiente estimado para a variável significativo a $1 \%$.

Nota 5: As variáveis nominais foram deflacionadas pelo IPCA (IBGE).

Conforme Tabela 17, em relação à significância estatística dos coeficientes estimados das variáveis e também com relação ao sinal esperado, os resultado desta estimação assemelham-se aos da estimação anterior.

Sobre a magnitude dos coeficientes estimados, dentre as variáveis representativas da dimensão amplitude do alcance, a diferença média no total de clientes (CLIEN) entre os grupos aumentou em relação à estimação anterior (697), e a diferença média no total de operações (OPER) também cresceu (1.743).

Relativamente à profundidade do alcance, a diferença média da variável valor médio dos empréstimos ou carteira ativa média $\left(M E_{-} C A\right)$ diminuiu 0,1 ponto percentual entre os grupos, conforme o esperado e sinalizado pela literatura. Nesta estimação, o coeficiente estimado da variável ME_OPER (média das operações) aumentou em 4, 3 pontos percentuais entre os grupos, ao contrário do esperado.

Em seguida, assim como foi feita a estimação controlando pela carteira ativa total em logaritmo (LCAT) e as dummies de tempo com os indicadores de desempenho financeiro, fezse o mesmo para os indicadores de desempenho social. Os resultados são exibidos na Tabela 18.

Tabela 18: Regressões controlando pela interação entre a carteira ativa total (LCAT) e as dummies de tempoIndicadores sociais

\begin{tabular}{|c|c|c|c|c|c|c|c|}
\hline Nome da variável & Código da variável & $\begin{array}{c}\mathbf{N}^{0} \text { de } \\
\text { observ. }\end{array}$ & $\begin{array}{l}\mathbf{N}^{0} \text { de } \\
\text { Coop. }\end{array}$ & $\begin{array}{c}\text { Coef. } \\
\text { MCDIR }\end{array}$ & $\underset{(\mathbf{P}>|\mathbf{t}|)}{\text { Sig }}$ & $\begin{array}{c}\text { Sinal } \\
\text { esperado }\end{array}$ & $\begin{array}{c}\text { Sinal } \\
\text { encontrado }\end{array}$ \\
\hline \multicolumn{8}{|c|}{ Amplitude do alcance } \\
\hline CLIEN & Wsoma cli om ${ }^{1}$ & 16.994 & 1.429 & 385,64 & $0,001 * * *$ & $(+)$ & $(+)$ \\
\hline OPER & Wsoma_op_om ${ }^{2}$ & 16.994 & 1.429 & $1.105,56$ & $0,000 * * *$ & $(+)$ & $(+)$ \\
\hline \multicolumn{8}{|c|}{ Profundidade do alcance } \\
\hline ME_CA & Wme_soma_lca_om & 16.993 & 1.429 & 0,000 & $0,062 *$ & $(-)$ & $(+)$ \\
\hline ME_OPER & Wme_soma_op_om & 16.994 & 1.429 & $-0,049$ & 0,336 & $(-)$ & () \\
\hline
\end{tabular}

Total de clientes ativos por modalidades: 1, 2, 3, 4 e submodalidades 1303 e 1304, 212 - empréstimo (microcrédito consumo) e 403 - financiamento (microcrédito produtivo).

${ }^{2}$ Total de operações por modalidades: 1, 2, 3, 4 e submodalidades 1303 e 1304, 212 - empréstimo (microcrédito consumo) e 403 - financiamento (microcrédito produtivo).

Nota 1: CLIEN: Total de clientes; OPER: Total de operações; ME_CA: Carteira ativa média; ME_OPER: Valor médio das operações.

Nota 2: Todas as variáveis foram winsorizadas a $10 \%$. 
Nota 3: As equações são estimadas pelo modelo de regressão com dados em painel desbalanceado efeitos fixos, com erros padrões robustos.

Nota $4:(*)$ coeficiente estimado para a variável significativo a $10 \% ;(* *)$ coeficiente estimado para a variável significativo a $5 \% ;(* * *)$ coeficiente estimado para a variável significativo a $1 \%$.

Nota 5: As variáveis nominais foram deflacionadas pelo IPCA (IBGE).

Ao impor um controle bem mais rígido, qual seja, a interação entre a carteira ativa total (LCAT) e as variáveis dummies de tempo, foram estatisticamente significantes os coeficientes estimados das seguintes variáveis representativas do desempenho social: no nível de significância de 1\%, total de clientes (CLIEN), total de operações (OPER); a 10\% de significância, carteira ativa média $\left(M E_{-} C A\right)$ ou valor médio dos empréstimos. O coeficiente estimado da variável $M E \_O P E R$ (média das operações) perdeu significância estatística após esse controle.

Com relação ao sinal esperado dos coeficientes estimados das variáveis analisadas, com exceção carteira ativa média $\left(M E_{-} C A\right)$ que apresentou um sinal contrário ao esperado, os demais estão de acordo com as expectativas.

No tocante à magnitude dos coeficientes estimados, dentre as variáveis representativas da dimensão amplitude do alcance, a diferença média entre os grupos no total de clientes (CLIEN) diminuiu (385) em relação às estimações anteriores, o que significa que a distância média entre os grupos deu-se em menor magnitude do que em todas as outras estimações anteriores. Isso decorre do fato de esta regressão ser a mais rígida em termos de controle. $\mathrm{O}$ mesmo ocorre com a diferença média do total de operações $(O P E R)$, a qual, nesta estimação, também foi reduzida (1.105).

No que corresponde à profundidade do alcance, a diferença média do coeficiente estimado da variável carteira ativa média $\left(M E_{-} C A\right)$ entre os grupos é 4,9 pontos percentuais menor após as mudanças ocorridas no microcrédito.

Em resumo, os resultados indicam que as variáveis proxies da dimensão amplitude do alcance, tanto em termos de magnitude como em relação ao sinal esperado, foram mais impactadas do que as variáveis representativas da dimensão profundidade do alcance, suscitando que as cooperativas estão sendo mais eficientes na primeira dimensão. Esses resultados estão de acordo com os objetivos dos programas PNMPO e CRESCER que são, em primeira instância, ampliar a oferta de microcrédito. Dito de outra forma, os resultados das regressões se referem ao efeito da intervenção. Aparentemente, ela foi mais eficaz para estimular a amplitude do que a profundidade do alcance.

Vale enfatizar que, a despeito de as análises das estatísticas descritivas realizadas apontarem características relativamente homogêneas entre os grupos de cooperativas que 
ofertam e que não ofertam microcrédito, a incerteza quanto ao atendimento do pressuposto da existência de tendências paralelas sugere cautela nas inferências. Às cooperativas é facultado escolher se ofertam ou não microcrédito no âmbito dos programas PNMPO e CRESCER. Ainda assim, as cooperativas que o fazem, notadamente as de interação solidária por vocação e comprometimento social, acabaram aderindo ainda que isso não tenha ocorrido em grande magnitude, como ficou evidente no presente estudo por meio da análise dos dados do MTE, do BCB e das entrevistas realizadas. Ademais, independentemente de ser ou não interessante do ponto de vista do desempenho financeiro, a adesão se deu, sobretudo em decorrência do double bottom line inerente às cooperativas. Muitas viram nos programas PNMPO e CRESCER a oportunidade de melhorarem o seu desempenho social por meio da massificação do microcrédito, o que permitiu melhorar o alcance. 


\section{CONCLUSÕES}

O presente trabalho teve por objetivo analisar os efeitos de mudanças regulatórias no microcrédito, no desempenho financeiro e social das cooperativas de crédito no Brasil. Para tanto, foram coletados dados em duas fontes: no Ministério do Trabalho e Emprego (MTE) e no Banco Central do Brasil (BCB), e realizadas algumas entrevistas com agentes qualificados das instituições ofertantes de microcrédito.

O PNMPO, como visto, é um marco na regulação do microcrédito no Brasil e é considerado tanto uma política de emprego (prova disso é que é gerido pelo MTE), quanto uma política social, por atender às camadas menos favorecidas economicamente e por estar vinculado ao Programa Brasil sem miséria, o qual por sua vez está subordinado ao Ministério do Desenvolvimento Social (MDS). O programa CRESCER, considerado uma extensão do PNMPO, dentre os seus objetivos almeja ser "uma porta de saída" para os beneficiários do Bolsa Família ${ }^{20}$.

As mudanças regulatórias no microcrédito implementadas pelo Governo Federal em 2011 visam prioritariamente ao alcance (a massificação) do microcrédito. No que tange a esse objetivo, o programa foi bem-sucedido. Todavia, as principais medidas implementadas, a saber, redução das taxas de juros e da TAC e a criação de subsídios, intuitivamente já sinalizam para um comprometimento do desempenho financeiro das instituições ofertantes por encarecer o custo da operação. O subsídio criado para compensar esse aumento no custo, de acordo com alguns entrevistados, não foi suficiente para promover a equalização (compensação) estabelecida em lei. Na percepção do entrevistado número 5, até o momento da realização da entrevista, a adesão ao programa CRESCER se restringiu aos bancos públicos.

Numa perspectiva mais geral, após as análises realizadas constata-se que:

a) A despeito das diversas iniciativas (programas e políticas) em prol do crescimento do microcrédito, as ações ainda se mostraram desarticuladas. Existe uma diversidade de instituições gerindo diferentes programas, por vezes com sobreposição de metas e objetivos que, ao que pareceu, não conversam entre si. Por exemplo, o programa do BNDES parece se sobrepor ao PNMPO e vice-versa. Os órgãos de fiscalização (BCB, Ministério da Fazenda, MTE e MDS) não

\footnotetext{
${ }^{20}$ Principal programa brasileiro de transferência direta de renda criado em 2003 com o objetivo de combater a extrema pobreza por meio da garantia do acesso à renda, a direitos sociais e a ações complementares, incluindo o acesso a crédito para pequenos empreendimentos. Um dos objetivos do programa CRESCER é justamente a emancipação dos beneficiários do Programa Bolsa Família. Segundo o MDS, 29\% dos tomadores de crédito via CRESCER também recebem Bolsa Família (www.mds.gov.br).
} 
compartilham ações nem informações. As instituições que operam nos três níveis são muito diferenciadas. Um único programa amplo e geral, como é o caso do PNMPO e CRESCER, não consegue alcançar todas as instituições igualmente.

b) A qualidade dos dados ainda é um grande problema. Isso dificulta estudos e pesquisas, sobretudo os relacionados à avaliação desses programas. Por exemplo, um dos informantes qualificados entrevistado afirmou não fornecer informações ao MTE desde 2010 e, ainda assim, o Ministério continuou a divulgar dados referentes a esta instituição. A IMF que possui o programa mais bem-sucedido, o Banco do Nordeste, se nega a fornecer informações, dificultando a realização de estudos e análises a respeito do assunto. Além disso, não se identificou que esta instituição realize um trabalho de forma colaborativa com outras, como ONGs e OSCIPs, por exemplo, até mesmo para compartilhar o acúmulo de experiência adquirido. Um dos agentes entrevistados afirmou que a instituição onde trabalha buscou, por diversas vezes, apoio e parceria do Banco do Nordeste, sem sucesso.

c) O programa CRESCER cumpriu o objetivo da massificação do microcrédito na medida em que, para cumprir as metas, os bancos públicos aumentaram a oferta de forma substancial. No entanto, segundo alguns entrevistados, os bancos não utilizaram a metodologia do microcrédito estipulada na lei em todas as operações de microcrédito produtivo realizadas. Muitos empréstimos foram feitos no balcão dos bancos, contrariando o princípio básico do microcrédito que é ofertar não somente recursos financeiros, mas todo um conjunto de serviços que o acompanha, como discutidos anteriormente. Outro efeito das medidas analisadas observado no presente estudo foi a redução da receita da $\operatorname{IMF} e$, consequentemente, da rentabilidade da operação em razão da redução das taxas de juros e da TAC. Com efeito, os bancos públicos foram mais diretamente afetados com o Programa CRESCER: as OSCIPs e as SCMs foram negativamente afetadas, tendo estas instituições reduzido a oferta de microcrédito de forma substancial como pôde ser observado nos dados do MTE. Os bancos privados, aparentemente, não aderiram ao CRESCER por não o considerarem economicamente viável, de acordo com os entrevistados. E as cooperativas de crédito, como mostraram as análises aqui realizadas, foram relativamente pouco afetadas em termos de desempenho financeiro. De maneira geral, após todas as estimações com e sem controles, supostamente foram influenciados os seguintes indicadores financeiros: (a) Qualidade dos Ativos: inadimplência (INAD), rendas 
de juros com operações de crédito em relação ao ativo total ajustado (REND_JR), rentabilidade da carteira de crédito $\left(R E N T \_C A R\right)$. Deste grupo, não foram afetados pelas mudanças: taxa de inadimplência (TX_INAD), margem de intermediação financeira $\left(M A R G_{-} F I N\right)$, resultado da intermediação financeira (RESULT_FIN) e resultado da intermediação financeira, considerando somente juros (RESULT_FIN_J); (b) Eficiência: custo operacional (CUST_OP), margem operacional (MARG_OP); (c) Rentabilidade: nenhuma variável deste grupo foi significativa estatisticamente. Já no que se refere à análise do desempenho social, nas estimativas com e sem controles, todos os coeficientes estimados mostraram significância estatística.

Algumas questões podem ser apreendidas ao final da pesquisa: (a) é importante que o trabalho colaborativo entre todos os atores sociais envolvidos seja potencializado a fim de somar esforços em prol do desenvolvimento do microcrédito; (b) o acompanhamento do crédito, se realizado por agentes que conhecem a comunidade local, pode facilitar o uso desta tecnologia que, como visto, contribui para a redução da inadimplência. As experiências bem sucedidas enunciam a importância dos laços de proximidade entre a IMF ofertante e os tomadores, isto é, o microcrédito produtivo não deve ser feito no balcão da instituição, mas no local onde as atividades produtivas acontecem. Para isso, é importante um conhecimento aprofundado acerca da natureza das atividades dos beneficiários e de suas respectivas demandas; (c) necessário se faz ainda intensificar as ações de educação financeira e de capacitação dos clientes e dos agentes de crédito.

No que toca especificamente às instituições de microfinanças, considera-se que estas devem estar comprometidas com a inclusão financeira (Morduch, 1999) ou com a prestação de serviços financeiros aos pobres (Ledgerwood, 1999). Quanto ao seu caráter dual: o double bottom line, há praticamente um consenso na literatura; a divergência entre os autores centrase no trade-off entre esses dois objetivos (Araújo, 2012; Bédécarrats et al., 2011; Borba, 2012; Foose \& Greenberg, 2008; Frank, 2008; Gonzalez, 2010; Gonzalez, 2010a; Kai, 2009; Kumar Kar, 2011; Sinha, 2006; Sinha \& Brar, 2005; Tulchin, 2004) ou sinergia (Brau e Woller, 2004; Cull et al., 2007; Cull et al., 2008; Gutiérrez-Nieto et al., 2007; Louis et al., 2013; Quayes, 2012; Schreiner, 2002;) entre os dois objetivos. Segundo Bédécarrats et al. (2013), a despeito de na América Latina ocorrer uma polarização em torno deste duplo objetivo, o Brasil escolheu outro caminho. A alternativa brasileira é um misto de instituições 
comercialmente orientadas a exemplo das SCMs e bancos com outras com enfoque mais social como as ONGs, OSCIPs e cooperativas de crédito.

Também a atuação direta do Estado brasileiro no segmento, segundo alguns autores (Deangelo, 2005; Yunus, 2010), deve-se dar "no sentido de induzir os agentes a oportunizarem operações de microcrédito e de estruturar um sistema a elas voltado" (Estigmara, 2008). No entanto, a despeito de o papel do Estado brasileiro ser considerado como demasiadamente intervencionista por bancos privados, as OSCIPs gostariam de ter mais apoio governamental, seja o meio da oferta de funding, preferencialmente via doações, como também por meio de assessoria e capacitação técnica, conforme opinião do entrevistado $\mathrm{n}^{\mathrm{o}} 01$.

No tocante às cooperativas de crédito, de acordo com a classificação de Bédécarrats et al. (2013), são instituições transformativas (não fazem parte da polarização existente entre as instituições onde predominam a lógica mercantil e as submetidas às políticas públicas) e, assim sendo, não consideram o desempenho financeiro necessário e suficiente para garantir a eficiência da instituição, almejando também alcançar objetivos sociais. As cooperativas de crédito são, por excelência e definição, instituições com double bottom line. Assim, as cooperativas que aumentaram a oferta de microcrédito durante o período analisado o fizeram, possivelmente, mais por vocação ou compromisso social e menos pelo estímulo financeiro via subsídio governamental.

Estes resultados encontrados no presente estudo sustentam-se na abordagem da Nova Economia Institucional (NEI), a qual atesta que o desempenho das instituições não observa somente os aspectos de eficiência econômico-financeiros.

Ainda no que tange particularmente às cooperativas de crédito, a natureza própria e a forma de constituição jurídica delas, sobretudo o princípio da autonomia e independência, não possibilitam uma intervenção estatal mais direta mesmo tratando-se de microfinanças e microcrédito. Sendo assim, qualquer que seja a política ou programa público implementado, às cooperativas sempre será facultativa a adesão tendo em vista que um dos princípios do cooperativismo é a autonomia e independência (controle democrático pelos seus membros). Não foi diferente com os programas PNMPO e CRESCER.

Os achados da pesquisa sugerem ainda que as cooperativas de crédito são um tipo de instituição adequado para operar o microcrédito no Brasil, pelas seguintes razões: (a) o seu formato institucional é o que mais se aproxima de uma autêntica IMF, ou seja, combina objetivos financeiros e sociais; (b) estão distribuídas praticamente pelo Brasil inteiro, podendo garantir a capilaridade necessária à oferta de microcrédito; (c) sua experiência com microcrédito tem mais de um século; (d) ao contrário das OSCIPs que têm dificuldade na 
captação de recursos, tanto podem captar recursos com o público como receber repasses de outras instituições financeiras por meio do Depósito Interfinanceiro de Microcrédito (DIM). Precisariam apenas adquirir o que as OSCIPs possuem, a saber: um bom conhecimento do mercado de microcrédito e a proximidade do cliente.

Uma questão relevante, apreendida por meio das entrevistas realizadas, é a ideia de as cooperativas de crédito terem a oportunidade de emprestar para não sócios ou ainda democratizar a constituição de novos sócios para aumentar o alcance do microcrédito tanto em termos de amplitude como de profundidade.

De outro lado, um obstáculo à expansão do microcrédito via cooperativas de crédito é que, em municípios com menor densidade populacional e menor dinamismo econômico a oferta de microcrédito não teria o adensamento necessário para cobrir os custos da operação, podendo comprometer a sustentabilidade da instituição. Neste caso, necessitaria firmar parcerias com outras instituições a fim de minimizar esses custos viabilizando econômica e financeiramente a oferta de microcrédito com uso de metodologia apropriada.

No entanto, de acordo com o entrevistado $\mathrm{n}^{\mathrm{o}} 05$, mesmo com a queda da receita em função, principalmente, da redução das taxas das operações de microcrédito, é possível garantir a sustentabilidade da Cooperativa pela maior escala e massificação do crédito. Outra questão importante apontada pelo entrevistado é que a maior oferta de microcrédito viabiliza a inclusão financeira garantindo impacto social e maior fidelização do associado.

No que diz respeito ao impacto da redução das taxas de juros e da TAC no desempenho das cooperativas, conforme o entrevistado $\mathrm{n}^{\mathrm{o}}$ 03, algumas cooperativas já praticavam taxas de juros entre $2,7 \%$ e $3,7 \%$ e não cobravam Taxa de Abertura de Crédito (TAC). Outras reduziram suas taxas após o CRESCER por causa da concorrência com os bancos públicos.

Em síntese, a despeito do crescimento considerável da oferta de microcrédito após as mudanças analisadas, essa oferta ainda é pouco representativa em relação ao total de crédito ofertado pelas instituições em geral. No que compete às cooperativas de crédito, a participação na oferta de microcrédito é ainda menor. Vale salientar que os valores reportados ao $\mathrm{BCB}$ pelas cooperativas dizem respeito à exigibilidade dos $2 \%$ dos depósitos à vista previsto em lei, sejam os valores captados pelas próprias cooperativas ou os repasses recebidos de outras instituições financeiras via DIM, além dos repasses de recursos oficiais como os do BNDES. As operações feitas com recursos próprios ainda que sejam caracterizadas como microcrédito pelo tamanho da operação, não são, muitas vezes, classificadas como microcrédito por não estarem contempladas na definição de microcrédito 
adotada pelo BCB, a qual como visto, é bem restrita. Por conseguinte, a real oferta de microcrédito pelas cooperativas pode estar sendo subestimada. Ainda assim, verifica-se que a oferta de microcrédito cresceu consideravelmente após as medidas analisadas.

O estudo permite concluir também que as referidas mudanças não exerceram grande influência nos indicadores de desempenho financeiro. Nos indicadores de desempenho social, o impacto parece ter sido relevante. Os indicadores sociais foram mais afetados nos estudos sem controles muito rígidos, como a inclusão da variável carteira ativa total (LCAT) como variável de controle, por exemplo. Por último, nota-se um crescimento considerável na oferta de microcrédito pelas cooperativas pós-mudanças regulatórias, mas esse crescimento não afetou significativamente o comportamento dos indicadores analisados.

Os resultados da presente pesquisa vão ao encontro da maioria dos estudos anteriores citados e das indicações teóricas apresentadas, com exceção do estudo de Pati (2012). A referida pesquisa investigou o impacto da regulação de instituições de microfinanças na sustentabilidade e no alcance das IMFs da Índia. Os resultados, para a amostra utilizada, demonstraram que a regulação não afetou os indicadores de desempenho financeiro e social examinados.

Conclui-se, portanto, que as evidências trazidas pelo presente estudo não foram suficientes para corroborar a tese originalmente proposta, a saber, as mudanças regulatórias ocorridas no microcrédito no Brasil influenciam negativamente os indicadores de desempenho financeiro e positivamente os indicadores de desempenho social das cooperativas de crédito. Sendo assim, a tese defendida é que as mudanças regulatórias ocorridas no microcrédito no Brasil impactaram com menor robustez os indicadores de desempenho financeiro e em maior magnitude os indicadores de desempenho social das cooperativas de crédito brasileiras durante o período de 2008 a 2014.

Os achados desta pesquisa podem ser úteis para todos aqueles que se interessam por microfinanças e microcrédito, desde os gestores das instituições, em especial de cooperativas de crédito, até os policy makers, cientistas políticos, cientistas sociais, acadêmicos e pesquisadores da área contábil, além dos beneficiários do microcrédito em geral. $\mathrm{O}$ microcrédito foi disseminado no mundo inteiro como uma grande "promessa"; no entanto, no Brasil esse segmento ainda não se desenvolveu na magnitude esperada não obstante todos os esforços empreendidos. Com base nas análises e evidências do presente estudo, considera-se o microcrédito no Brasil mais como um "enigma", uma vez que, a despeito das condições favoráveis, ainda não se consolidou. Há ainda muito por fazer, e o presente estudo é mais um elemento na construção de uma agenda de maior desenvolvimento do microcrédito no Brasil. 
O estudo contribui para uma melhor percepção do tema microcrédito, o qual ainda é incipiente, controverso, complexo e multifacetado. Também auxilia os participantes em geral do mercado de microcrédito: governo, reguladores, ONGs, OSCIPs, bancos, cooperativas, Banco Central, a entender os possíveis efeitos positivos e negativos de intervenções dessa natureza.

\subsection{Sugestões de estudos futuros}

Por entender que uma tese não é a conclusão de um estudo, mas é, antes de tudo, uma provocação de futuras pesquisas, este estudo não se encerra aqui. Pelo contrário, foi tão somente um ponto de partida para uma frutífera agenda de pesquisa que ora se apresenta.

Esta pesquisa, que teve início com uma pergunta, foi finalizada com diversas outras questões. Algumas inquietações foram reduzidas ao longo dos quase cinco anos de estudo, porém, muitas outras surgiram no decorrer do processo. Isso ocorreu porque a temática é ampla, complexa e instigante, com um significativo apelo social, além de constituir tema relativamente pouco explorado na área de Ciências Sociais Aplicadas, sobretudo na Contabilidade.

Intriga o fato de, a despeito de todo o esforço por parte dos governos nas três esferas e dos múltiplos agentes envolvidos, o microcrédito no Brasil não ter crescido na dimensão esperada pelos programas e políticas implementados até então. Esse fato pode ser sintetizado como "o enigma brasileiro do microcrédito", parafraseando a expressão cunhada por Aguiar (1958), quando se referiu a uma questão semelhante em relação ao não crescimento econômico no Estado da Bahia nos anos de 1950, constituindo o famoso "enigma baiano"21. O então denominado "enigma baiano" referia-se às causas da não industrialização da Bahia no período, quando estava em pleno vigor o projeto desenvolvimentista nacional via substituição de importações pautado na industrialização das regiões mais pobres do Brasil, Norte e Nordeste. Assim, pretende-se desvendar o "enigma brasileiro do microcrédito", com base em sugestões de estudos futuros elencados aqui.

1. Estudos mais abrangentes que comtemplem os demais tipos de instituições ofertantes de microcrédito e que possam ser extrapolados conferindo maior validade externa;

\footnotetext{
${ }^{21}$ Para mais detalhes sobre o "enigma baiano", consulte a obra: Aguiar, P. de. (1958). Notas sobre o "enigma baiano": Edição conjunta com a Comissão de Planejamento Econômico do Estado da Bahia. [Salvador]: Progresso.
} 
2. Estudos qualitativos por meio de entrevistas com mais profundidade aos agentes envolvidos a fim de compreender melhor a oferta de microcrédito no Brasil e a complexidade das instituições ofertantes;

3. Um estudo qualitativo com as cooperativas de crédito na tentativa de identificar a sua pouca inserção no segmento de microcrédito produtivo e orientado;

4. Um estudo com as OSCIPs, utilizando a base de dados Cines Público, para compreender melhor a retração das atividades das OSCIPs de microcrédito;

5. Um estudo que identifique o impacto do CRESCER - Programa Nacional de Microcrédito nos beneficiários do programa Bolsa Família;

6. Estudos de averiguação do impacto da Estratégia Nacional de Educação Financeira (Enel), que se tornou uma política de Estado, no segmento de microfinanças e microcrédito;

7. Estudos relacionados à ampliação da inclusão financeira por meio de maior oferta e diversificação de produtos micro financeiros, a exemplo do micros seguro. 


\section{REFERÊNCIAS}

Afanasieff, T. S., Lhacer, P. M., \& Nakane, M. I. (2002). The determinants of bank interest spread in Brazil. Money Affairs, 15(2), 183-207.

Aghion, B. A. de, \& Morduch, J. (2005). The Economics of Microfinance. (2nd ed.). Cambridge: The MIT Press.

Ahlin, C., \& Townsend, R. M. (2007). Selection into and across credit contracts: theory and field research. Journal of Econometrics, 136(2), 665-698.

Akerlof, G. A. (1970). The Market for "Lemons": Quality, Uncertainty and Market Mechanism. Quarterly Journal of Economics, august.

Ala-Harja, M., \& Helgason, S. (2000). Em direção às melhores práticas de avaliação. Revista Do Serviço Público, 4, 56.

Alinsunurin, M. K. (2014). Efficiency of microfinance institutions in the Philippines. Enterprise Development and Microfinance, Vol. 25 No. 4. DOI: http://dx.doi.org/10.3362/1755-1986.2014.031

Alves, S. D. da S., \& Soares, M. M. (2004). Microfinanças - Democratização do Crédito no Brasil - Atuação do Banco Central. Brasília: Banco Central do Brasil.

Angrist, J. D. \& Pischke, J. S. (2008). Mostly Harmless Econometrics: An Empiricistís Companion. Massachusetts Institute of Technology (MIT). Retrieved from http://www.development.wne.uw.edu.pl/uploads/Main/recrut_econometrics.pdf

Araújo, E. A. (2012). Análise do desempenho financeiro e social das instituições de microcrédito brasileiras. Universidade Federal de Lavras. Retrieved from http://repositorio.ufla.br/bitstream/1/472/1/TESE_Análise do desempenho financeiro e social das instituições de microcrédito brasileiras.pdf

Armendáriz, B., \& Morduch, J. (2010). The economics of microfinance (2nd ed.). London: MIT. Retive from https://mitpress.mit.edu/sites/default/files/titles/content/9780262513982_sch_0001.pdf

Assaf Neto, A. (2010). Estrutura e análise de balanços: um enfoque econômico-financeiro.9. ed. - São Paulo: Atlas.

Baer, M., \& Lichtensztejn, S. (1987). Fundo Monetário Internacional e Banco Mundial: estratégias e políticas do poder financeiro. São Paulo: Brasiliense.

Barone, F. M., \& Sader, E. (2008). Acesso ao crédito no Brasil: evolução e perspectivas. Revista de Administração Pública, 42(6), 1249-1267. http://doi.org/10.1590/S003476122008000600012

Barros, R. P. de, \& Lima, L. (2012). Avaliação de impacto de programas sociais por que, para que e quando fazer? In N. M. Filho (Ed.), Avaliação econômica de projetos sociais (pp. 13-29). São Paulo: Dinâmica Gráfica e Editora. 
Barry, T. A., \& Tacneng, R. (2014). The Impact of Governance and Institutional Quality on MFI Outreach and Financial Performance in Sub-Saharan Africa. World Development, 58, 1-20. http://doi.org/10.1016/j.worlddev.2013.12.006

Bassem, B. S. (2009). Governance and performance of microfinance institutions in Mediterranean countries. Journal of Business Economics and Management, 10(1), 3143. http://doi.org/10.3846/1611-1699.2009.10.31-43

Bastelaer, T. V. (2000). Does Social Capital facilitate the poor's access to credit? A review of the microeconomic literature. Washington, D.C.: The World Bank. Social Capital Initiative.Working Paper Series no. 8. Group. Working Paper Series no. 8. http://siteresources.worldbank.org/INTSOCIALCAPITAL/Resources/Social-CapitalInitiative-Working-Paper-Series/SCI-WPS-08.

BCB. (1999). Banco Central do Brasil. Resolução no 2.627, de 03 de agosto de 1999. Retrieved from http://www.bcb.gov.br/pre/normativos/res/1999/pdf/res_2627_v1_O.pdf

BCB. (2002). Banco Central do Brasil. Resolução no 3.058, de 20 de dezembro de 2002. Retrieved from http://www.bcb.gov.br/pre/normativos/res/2002/pdf/res_3058_v1_O.pdf

BCB. (2003). Banco Central do Brasil. Resolução no 3.106, de 25 de junho de 2003. Retrieved from https://www.bcb.gov.br/pre/denor/port/2003/1/\%5C3.106,\%20de $\% 2025 \% 20 \mathrm{de} \% 20 \mathrm{junh}$ o.asp

BCB. (2003a). Banco Central do Brasil. Resolução no 3.109, de 24 de julho de 2003. Retrieved from http://www.bcb.gov.br/pre/normativos/res/2003/pdf/res_3109_v1_O.pdf

BCB. (2005). Banco Central do Brasil. Sistema de Informações de Crédito do Banco Central. Retrieved from http://www.bcb.gov.br/fis/crc/ftp/scr.pdf

BCB. (2010). Banco Central do Brasil. Resolução no 3.859, de 27 de maio de 2010. Retrieved from http://www.bcb.gov.br/pre/normativos/res/2010/pdf/res_3859_v3_P.pdf

BCB. (2011). Banco Central do Brasil. Resolução no 4.000, de 25 de agosto de 2011.

Retrieved from

http://www.bcb.gov.br/pre/normativos/busca/downloadNormativo.asp?arquivo=/Lists/N ormativos/Attachments/49342/Res_4000_v3_P.pdf

BCB. (2012). Banco Central do Brasil. Resolução no 4.152, de 30 de outubro de 2012.

Retrieved from

http://www.bcb.gov.br/pre/normativos/busca/downloadNormativo.asp?arquivo=/Lists/N ormativos/Attachments/49086/Res_4152_v1_O.pdf

BCB. (2012a). Banco Central do Brasil. Resolução no 4.153, de 30 de outubro de 2012.

Retrieved from http://www.bcb.gov.br/pre/normativos/res/2012/pdf/res_4153_v1_O.pdf

BCB. (2013). Banco Central do Brasil. Resolução no 4.242, de 28 de junho de 2013.

Retrieved from http://www.bcb.gov.br/pre/normativos/res/2013/pdf/res_4242_v1_O.pdf

BCB. (2014). Banco Central do Brasil. Relatório de Estabilidade Financeira, vol. 12, n. 2.

Publicação semestral. Brasília: BCB. 
BCB. (2015). Banco Central do Brasil. Estudo Especial Panorama do Microcrédito. Departamento de Monitoramento do Sistema Financeiro - Desig Departamento de Educação Financeira - Depef. Brasília: BCB.

BCB. (2015a). Banco Central do Brasil. Relatório de inclusão financeira. - N. 3 -. Brasília: BCB.

Bédécarrats, F., Bastiaensen, J., \& Doligez, F. (2013). Cooptación, cooperación o competencia? Microfinanzas y nuevas izquierdas en Bolivia, Ecuador y Nicaragua. Encuentro, (94), 62-81. Retrieved from http://lamjol.info/index.php/ENCUENTRO/article/view/1088

Bédécarrats, F., Baur, S., \& Lapenu, C. (2011). Combining social and financial performance: a paradox? In 2011 Global Microcredit Summit (pp. 1-15). Valladolid, Spain.

Belloni, J. A., Matos, F. de, Ruas, C., Marinho, D. N., Cacciamali, M. C., \& Pereira, M. do P. (2015). A Politica e a Atividade de Microcrédito como Instrumentos de Geração de Trabalho e Renda e Inclusão Produtiva. Brasília: DATAUnB-FUP, SPPE-MTE.

Beneditto, E. de A. N. Di, \& Silva, R. N. S. da. (2008). Análise do Nível de Transparência das Instituições Financeiras Brasileiras em Relação ao Acordo com o Novo Acordo de Capitais (Basiléia II)- Um estudo de caso múltiplo. Brazilian Business Review, 5(3), 192-208.

Berenbach, S., \& Churchill, C. (1997). Regulation and supervision of microfinance institutions: Experience from Latin America, Asia and Africa (No. 1). Retrieved from https://centerforfinancialinclusionblog.files.wordpress.com/2011/10/regulation-andsupervision-of-microfinance-institutions.pdf

Bernardoni, D. L., Souza, M. C. de, \& Peixe, B. C. S. (2008). Fortalecimento da função avaliação de políticas públicas: estudo de caso do processo de avaliação da política de emprego e renda da Secretaria de Estado do Trabalho, Emprego e Promoção Social do Paraná. In B. C. S. Peixe \& et al (Eds.), Gestão de Políticas Públicas no Paraná (pp. 381-393). Curitiba: Progressiva. Retrieved from http://www.escoladegoverno.pr.gov.br/arquivos/File/gestao_de_politicas_publicas_no_p arana_coletanea_de_estudos/cap_6_trabalho_emprego_e_promocao_social/capitulo_6_1 .pdf

Bialoskorski Neto, S. (1998). Cooperativas: economia, crescimento e estrutura de capital. Doutorado em Economia Aplicada. Universidade de São Paulo. Retrieved from http://www.fearp.usp.br/cooperativismo/tese_sigismundo_1998.pdf

Biggar, D. (2011). The fifty most important papers in the Economics of Regulation. AER Working Paper Series, (3), 1-96.

Bittencourt, G. A. (2001). Cooperativas de Crédito Solidário: Constituição e Funcionamento. - $2^{\mathrm{a}}$ ed. - Campinas: Unicamp.

Bogan, V. L. (2012). Capital Structure and Sustainability: An Empirical Study of Microfinance Institutions. Review of Economics and Statistics, 94(4), 1045-1058. http://doi.org/10.1162/REST_a_00223 
Borba, P. da R. F. (2012). Relação entre desempenho financeiro e desempenho social de instituições de microfinanças na América Latina. (Tese de Doutorado). Universidade de São Paulo.

Bos, J. W.B. \& Millone, M. (2015). Practice What You Preach: Microfinance Business Models and Operational Efficiency. World Development, Elsevier, vol. 70(C), pages 2842 .

Braga, T. S. (2011). Programas públicos de microcrédito produtivo orientado: uma avaliação da eficácia do crediamigo para a inserção da população de baixa renda do setor informal no mercado de crédito. Universidade Federal da Bahia. Retrieved from http://www.adm.ufba.br/pt-br/publicacao/programas-publicos-microcredito-produtivoorientado-avaliacao-eficacia-crediamigo-para

Brasil (1971). Lei no 5.764, de 16 de dezembro de 1971, Presidência da República. Retrieved from http://www.planalto.gov.br/ccivil_03/leis/L5764.htm

Brasil (1990). Lei no 7.998, de 11 de janeiro de 1990, Presidência da República. Retrieved from http://www.planalto.gov.br/ccivil_03/leis/L7998.htm

Brasil (1990a). Lei $n^{\circ}$ 8.019, de 11 de abril de 1990, Presidência da República. Retrieved from http://www.planalto.gov.br/ccivil_03/leis/L8019.htm

Brasil (1999). Lei no 9.790, de 23 de março de 1999, Presidência da República. Retrieved from http://www.planalto.gov.br/ccivil_03/leis/19790.htm

Brasil (1999a). Decreto $n^{\circ}$ 3.100, de 1999, Presidência da República. Retrieved from http://www.planalto.gov.br/ccivil_03/decreto/d3100.htm

Brasil (2001). Lei $n^{-}$10.194, de 14 de fevereiro de 2001, Presidência da República. Retrieved from http://www.planalto.gov.br/ccivil_03/leis/LEIS_2001/L10194.htm

Brasil (2003). Lei $n^{-}$10.735, de 11 de setembro de 2003, Presidência da República. Retrieved from http://www.planalto.gov.br/ccivil_03/leis/2003/L10.735.htm

Brasil (2005). Lei $n^{\circ}$ 11.110, de 25 de abril de 2005, Presidência da República. Retrieved from http://www.planalto.gov.br/Ccivil_03/_Ato2004-2006/2005/Lei/111110.htm

Brasil (2008) Decreto n 6.607, de 21 de outubro de 2008, Presidência da República. Retrieved from http://www.planalto.gov.br/ccivil_03/_Ato20072010/2008/Decreto/D6607.htm

Brasil (2011). Medida Provisória $n^{\circ}$ 543, de 24 de agosto de 2011, Presidência da República. Retive from http://www.planalto.gov.br/ccivil_03/_Ato2011-2014/2011/Mpv/543.htm

Brasil (2012). Lei no 12.666, de 14 de junho de 2012, Presidência da República. Retive from http://www.planalto.gov.br/ccivil_03/_ato2011-2014/2012/Lei/L12666.htm

Brasil (2012a). Lei $n^{-}$12.613, de 18 de abril de 2012, Presidência da República. Retive from http://www.planalto.gov.br/ccivil_03/_ato2011-2014/2012/Lei/L12613.htm

Brasil (2013). Portaria no 411, do Ministério da Fazenda, de 10 de julho de 2013, 
Presidência da República. Retive from http://fazenda.gov.br/acesso-ainformacao/institucional/legislacao/2013/portaria-no.-411-de-10-de-julho-de-2013

Brasil (2014). Portaria nº 83, do Ministério da Fazenda, de 21 de março de 2014, Presidência da República. Retive from http://fazenda.gov.br/acesso-ainformacao/institucional/legislacao/2014/portaria-no-83-de-21-de-marco-de-2014-1

Brau, J. C., \& Woller, G. M. (2004). Microfinance: A comprehensive review of the existing literature. Journal of Entrepreneurial Finance, 9(1), 1-27.

Bruett, T., Summerlin, R., \& D’Onófrio, S. (2002). Técnicas de gestão microfinanceira. Rio de Janeiro: BNDES.

Bucci, M. P. D. (1997). Políticas públicas e direito administrativo. Revista de Informação Legislativa, 34, 89-98.

Bucci, M. P. D. (2006). Direito Administrativo e Políticas Públicas. Sao Paulo: Saraiva.

Búrigo (2006), F. L. Finanças e solidariedade: o cooperativismo de crédito rural solidário no Brasil. Estudos Sociedade e Agricultura (UFRJ), Rio de Janeiro, v. 14, n. 2, p. 312-349.

Bushman, R. M. (2014). Thoughts on financial accounting and the banking industry. Journal of Accounting and Economics, 58(2-3), 384-395.

http://doi.org/10.1016/j.jacceco.2014.09.004

Cacciamali, M. C., Chahad, J. P. Z., \& Tatei, F. (2008). Microfinanças e Política Pública na América Latina. Cadernos PROLAM/USP, 1(8), 149-172.

Carvalho, F. L. de, Diaz, M. D. M., Bialoskorski Neto, S., \& Kalatzis, A. E. G. (2015). Saída e insucesso das cooperativas de crédito no Brasil: uma análise do risco. Revista Contabilidade \& Finanças, 26(67), 70-84. http://doi.org/10.1590/1808-057x201411390

Carvalho, S. N. de. (2003). Avaliação de programas sociais: balanço das experiências e contribuição para o debate. São Paulo em Perspectiva, 17(3-4), 185-197. http://doi.org/10.1590/S0102-88392003000300019

Cassar, A., Crowley, L., \& Wydick, B. (2007). The effect of social capital on group loan repayment: evidence from field experiments. The Economic Journal, 117(517), F85F106.

CEBDS. (2013). Conselho Empresarial Brasileiro para o Desenvolvimento Sustentável. Microfinanças, Microcrédito e Microsseguro no Brasil: O papel das instituições financeiras. Retrieved from http://cebds.org/wpcontent/uploads/2014/02/microfina\%C3\%A7as1.pdf

CGAP. (2002). Consultative Group to Assist the Poorest. Annual Report 2002. Washington D. C.

CGAP. (2003). Consultative Group to Assist the Poorest. Annual Report 2003. Washington D. C.

Christen, R. P., Lyman, T. R., \& Rosenberg, R. (2003). Guiding Principles on Regulation and 
Supervision of Microfinance. CGAP/The World Bank Group. Washington D. C.: CGAP/The World Bank Group. Retrieved from http://www.eiod.org/uploads/Publications/Pdf/Guideline_disclosure.pdf

Christen, R. P., Rhyne, E., Vogel, R. C., \& McKean, C. (1995). Maximizing the outreach of microenterprise finance: an analysis of sucessful microfinance programs.Coelho, A. C.; Soutes, D. O.; Martins, G. A. (2010). Abordagens Metodológicas na área "Contabilidade para Usuários Externos”. REPeC - Revista de Educação e Pesquisa em Contabilidade, Brasília, v. 4, n. 1, art. 2, p. 18-37, jan/abr.

Christen, R. P., \& Rosenberg, R. (2000). The Rush to Regulate: Legal Frameworks for Microfinance (No. 4). Occasional Paper. Washington D. C. Retrieved from http://www.cgap.org/publications/rush-regulate-legal-frameworks-microfinance

Coleman, J. S. (1988). Social Capital in the Creation of Human Capital. American Journal of Sociology, Chicago, v. 94, Supplement, p. S95- S120.

Comparato, F. K. (1998). Ensaio sobre o juízo de constitucionalidade de políticas públicas. Revista de Informação Legislativa, 35(abr/jun.), 39-48.

Conning, J. (1996). Group Lending, Moral Hazard, and the Creation of Social Collateral. IRIS Working Paper No. 195. http://pdf.usaid.gov/pdf_docs/Pnaby490.pdf.

Conning, J. (1999). Outreach, sustainability and leverage in monitored and peer-monitored lending. Journal of Development Economics, 60(1), 51-77. http://doi.org/10.1016/S0304-3878(99)00036-X

Costa, F., \& Castanhar, J. (2003). Avaliação de programas públicos: desafios conceituais e metodológicos. Revista de Administração Pública, 37(5), 969-992. Retrieved from http://bibliotecadigital.fgv.br/ojs/index.php/rap/article/viewArticle/6509

Cozarenco, A., \& Szafarz, A. (2014). Microcredit in developed countries: unexpected consequences of loan ceilings. Working Papers CEB (Centre Emile Bernheim), No. 14. Retrieved from http://www.iap-socent.be/sites/default/files/SOCENT\%20Pub\%20201405\%20(wp14015).pdf.

Cull, R., Demirgüç-Kunt, A., \& Morduch, J. (2007). Financial performance and outreach: a global analysis of leading microbanks. The Economic Journal, 117(517), F107-F133. http://doi.org/10.1111/j.1468-0297.2007.02017.x

Cull, R., Demirgüç-Kunt, A., \& Morduch, J. (2008). Microfinance Meets the Market (Policy Research Working Paper No. 4630). Policy Research Working Paper (Vol. 4630). Washington D. C.

Dantas, J. A., de Medeiros, O. R., \& Capelletto, L. R. (2012). Determinantes do spread bancário ex post no mercado brasileiro. Revista de Administração Mackenzie, 13(4), 48.

Deangelo, J. O. (2005). Microfinanças: contorno e ambiguidades da regulação brasileira. Revista de Direito Bancário e do Mercado de Capitais: RDB, 8(30), 220-241.

Deininger, K., \& Liu, Y. (2013). Welfare and Poverty Impacts of India s National Rural Employment Guarantee Scheme: Evidence from Andhra Pradesh (Vol. 1289). Intl Food 
Policy Res Inst. Retrieved from https://books.google.com.br/books?hl=pt-

$\mathrm{BR} \& 1 \mathrm{r}=\& \mathrm{id}=\mathrm{NXn} 2 \mathrm{AQAAQBAJ} \& \mathrm{oi}=\mathrm{fnd} \& \mathrm{pg}=\mathrm{PR} 5 \& \mathrm{dq}=$ Deininger $,+\mathrm{K} .+\% 26+\mathrm{Liu},+\mathrm{Y} .+$ (2013).+Welfare+and+Poverty+Impacts + of + India $\% 27 \mathrm{~s}+$ National+Rural:+Evidence + fro $\mathrm{m}+$ Andhra + Pradesh.+ Working + Paper\&ots $=$ mEN2lf3GjS\&sig $=$ jfwfTCbi0KINQNk2pT qDU4gSxU\#v $=$ onepage \&q=Deininger $\% 2 C \% 20 \mathrm{~K} . \% 20 \% 26 \% 20 \mathrm{Liu} \% 2 \mathrm{C} \% 20 \mathrm{Y} . \% 20(201$ 3). $\% 20$ Welfare $\% 20$ and $\% 20$ Poverty $\% 20$ Impacts $\% 20$ of $\% 20$ India's $\% 20$ National $\% 20$ Rura $1 \% 3 \mathrm{~A} \% 20$ Evidence $\% 20$ from $\% 20$ Andhra $\% 20$ Pradesh.\%20Working\%20Paper\&f=false

Den Hertog, J. A. (2010). Review of economic theories of regulation. Tjalling C. Koopmans Institute Discussion Paper Series, 10(18), 1-59. Retrieved from http://igiturarchive.library.uu.nl/CTK/2011-0110-200311/UUindex.html

Estigara, A. (2008). Desenvolvimento sustentável, democracia econômica e politicas públicas: uma análise a partir do microcrédito. (Dissertação de Mestrado). Pontifícia Universidade Católica do Paraná.

Fachini, C. (2005). Sustentabilidade financeira e custos de transação em uma organização de microcrédito no Brasil. Universidade de São Paulo.

Foose, L., \& Greenberg, A. (2008). The double bottom line: Evaluating social performance in microfinance. Microbanking Bulletin, (17), 12-16. Retrieved from http://www.themix.org/sites/default/files/MBB 17 - Evaluating Social Performance.pdf

Founanou, M., \& Ratsimalahelo, Z. (2012). Regulation and supervision of microfinance institutions: an example of cooperative credit society (No. MPRA Paper No. 39581). Munich. Retrieved from https://mpra.ub.uni-muenchen.de/39581/

Frank, C. (2008). Stemming the Tide of Mission Drift: Microfinance Transformations and the Double Bottom Line (WWB FOCUS NOTE No. SD). WWB FOCUS NOTE. Washington D. C. Retrieved from http://www.microfinancegateway.org/sites/default/files/mfg-enpaper-stemming-the-tide-of-mission-drift-microfinance-transformations-and-the-doublebottom-line-apr-2008.pdf

Gaboury, A., \& Quirion, M. (2006). Why we can no longer afford to ignore financial cooperatives in the effort to increase access to financial services. Développement International Desjardins (DID), Québec, Canada.

Gakhar, K. \& Meetu (2013). Financial performance and outreach of microfinance institutions: is there a trade- off? - an empirical study of indian economy. Sona Global Management Review, Volume 7.

Galema, R., Lensink, R., \& Mersland, R. (2012). Do Powerful CEOs Determine Microfinance Performance? Journal of Management Studies, 49(4), 718-742. http://doi.org/10.1111/j.1467-6486.2012.01046.x

Gertler, P. J., Martinez, S., Premand, P., Rawlings, L. B., \& Vermeersch, C. M. J. (2011). Impact Evaluation in Practice. The World Bank Publications. Washington D. C.: The World Bank. http://doi.org/10.1596/978-0-8213-8541-8

Gil, A. C. (1999). Métodos e técnicas de pesquisa social. - 5. ed. - São Paulo: Atlas.

Gonzalez, A. (2010). Microfinance Synergies and Trade-offs: Microfinance Information 
Exchange Bulletin, (7), 1-15.

Gonzalez. A. (2010a). Is Microfinance Growing Too Fast? MIX Data Brief No. 5. Retrieved from http://www.themix.org/sites/default/files/MIX\%20Data\%20Brief\%205\%20$\% 20$ Is $\% 20$ microfinance $\% 20$ growing $\% 20$ too $\% 20$ fast.pdf

Gutiérrez-Nieto, B., Serrano-Cinca, C., \& Molinero, C. M. (2007). Social efficiency in microfinance institutions. Journal of the Operational Research Society, 60(1), 104-119. http://doi.org/10.1057/palgrave.jors.2602527

Hartarska, V. (2005). Governance and performance of microfinance institutions in Central and Eastern Europe and the Newly Independent States. World Development, 33(10), 1627-1643. http://doi.org/10.1016/j.worlddev.2005.06.001

Hartarska, V., \& Mersland, R. (2012). Which Governance Mechanisms Promote Efficiency in Reaching Poor Clients? Evidence from Rated Microfinance Institutions. European Financial Management, 18(2), 218-239. http://doi.org/10.1111/j.1468036X.2009.00524.x

Hartarska, V., \& Nadolnyak, D. (2008). An impact analysis of microfinance in Bosnia and Herzegovina. World Development, 36(12), 2605-2619.

Hartarska, V., Nadolnyak, D., \& Shen, X. (2012). Efficiency in Microfinance Cooperatives. Revista Iberoamericana de Estudios de Desarrollo/Iberoamerican Journal of Development Studies, 1(2), 52-75.

Hermes, N., Lensink, R., \& Meesters, A. (2009). Financial Development and the Efficiency of Microfinance Institutions. SSRN Electronic Journal, 1-29. http://doi.org/10.2139/ssrn.1396202

Hermes, N., Lensink, R., \& Meesters, A. (2011). Outreach and Efficiency of Microfinance Institutions. World Development, 39(6), 938-948. http://doi.org/10.1016/j.worlddev.2009.10.018

Hermes, N., \& Meesters, A. (2011). The performance of microfinance institutions: do macro conditions matter? The handbook of microfinance (pp. 173-202). Singapore: World Scientific.

Hulme, D., \& Mosley, P. (1996). Finance against poverty (Vol. 2). Psychology Press. London: Routledge Retrieved from http://samples.sainsburysebooks.co.uk/9781134803781_sample_858774.pdf

Huppi, M., \& Feder, G. (1990). The role of groups and credit cooperatives in rural lending. The World Bank Research Observer, 5(2), 187-204. https://scholar.google.com.br/scholar?q=Huppi $\% 2 \mathrm{C}+\mathrm{M} .+\% 26+$ Feder $\% 2 \mathrm{C}+\mathrm{G} .+\mathrm{The}+\mathrm{The}$ + Role + of + Groups + and + Credit + Cooperatives + in + Rural + Lending + PPR + Working + Paper + Series + World + Bank\&btnG $=\& h l=p t-B R \&$ as_sdt $=0 \% 2 \mathrm{C} 5$

Iudícibus, S. de. (2009). Análise de balanços (10a ed.). Sao Paulo: Atlas.

Janda, K., \& Zetek, P. (2014). The impact of public spending on the performance of microfinance institutions (No. MPRA Paper No. 55690). Munich. 
Jansson, T., \& Wenner, M. (1997). Financial Regulation and Its significance for Microfinance in Latin America and the Caribbean. Washington D. C.

Jensen, M. C., \& Meckling, W. H. (1976). Theory of the firm: Managerial behavior, agency costs and ownership structure. Journal of financial economics, 3(4), 305-360.

Johnson, S. (2013). From microfinance to inclusive financial markets: the challenge of social regulation. Oxford Development Studies, 41, 35-53. http://doi.org/10.1080/13600818.2012.734799

Kaboski, J. P., \& Townsend, R. M. (2005). Policies and Impact: An Analysis of Village-Level Microfinance Institutions. Journal of the european economic Association, 3(1), 1-50.

Kaboski, J. P. \& Townsend, R. M. (2011). A Structural Evaluation of a Large-Scale QuasiExperimental Microfinance Initiative. Econometrica. Sep; 79(5): 1357-1406. doi:10.3982/ECTA7079

Kai, H. (2009). Competition and wide outreach of Microfinance institutions. Economics Bulletin, 29(4), 2628-2639.

Kar, A. K. (2010). Sustainability and Mission Drift in Microfinance. Hanken School of Economics. Retrieved from https://helda.helsinki.fi/bitstream/handle/10227/720/217978-952-232-099-5.pdf?sequence

Kipesha, E. F., \& Zhang, X. (2013). Sustainability, profitability and outreach tradeoffs: evidences from microfinance institutions in East Africa. European Journal of Business and Management, 5(8), 136-149.

Kumar, A. (2004). BRASIL: acesso a serviços financeiros. (A. Kumar, Ed.). Rio de Janeiro: IPEA/Banco Mundial.

Kumar Kar, A. (2011). Microfinance Institutions: A Cross-Country Empirical Investigation of Outreach and Sustainability. Journal of Small Business \& Entrepreneurship, 24(3), 427446. http://doi.org/10.1080/08276331.2011.10593547

Labie, M. \& Périlleux, A. (2008). Corporate Governance in Microfinance : Credit Unions. CERMi - Center for European Research in Microfinance. Working Paper $N^{\circ}$ 08/003. Université Libre de Bruxelles - Solvay Business School.

Lapenu, C. (2007). Recent advances in agricultural finance: supply and strategies. A review of literature and experience.

Lauer, K., \& Staschen, S. (2013). Regulation. In J. Ledgerwood, J. Earne, \& C. Nelson (Eds.), The new microfinance handbook: a financial market system perspective (pp. 413-436). Washington D. C.: International Bank for Reconstruction and Development/The World Bank.

Laughlin, R. (2007). Critical reflections on research approaches, accounting regulation and the regulation of accounting. The British Accounting Review, v. 39, p. 271-289.

Ledgerwood, J. (1999). Microfinance handbook: an institutional and financial perspective. Washington D. C.: International Bank for Reconstruction and Development/The World 
Bank. Retrieved from

https://openknowledge.worldbank.org/bitstream/handle/10986/12383/18771.pdf

Leismann, E. L., \& Carmona, D. E. M. (2008). Sustentabilidade em instituições de microfinanças. Ciências Sociais Aplicadas em Revista - UNIOESTE/MCR - v. 8 - n. 15 $2^{\circ}$ sem 2008 - p. 183-198 - ISSN 1679-348X.

Lima, V. de S. (2004). Uma análise dos efeitos da regulação do setor de microfinanças brasileiro: o caso das sociedades de crédito ao microempreendedor. Fundação Getúlio Vargas. Retrieved from https://bibliotecadigital.fgv.br/dspace/handle/10438/3335

Loubière, J., Devaney, P., \& Rhyne, E. (2004). Supervising \& regulating microfinance in the context of financial sector liberalization. Report to the Tinker Foundation. Retrieved from http://ww.w.sa-dhan.net

Louis, P., Seret, A., \& Baesens, B. (2013). Financial Efficiency and Social Impact of Microfinance Institutions Using Self-Organizing Maps. World Development, 46, $197-$ 210. http://doi.org/10.1016/j.worlddev.2013.02.006

Luzzi, G. F., \& Weber, S. (2006). Measuring the Performance of Microfinance Institutions. SSRN Electronic Journal, 1-17 17 http://doi.org/10.2139/ssrn.918750

Luzzi, G. F., \& Weber, S. (2007). Measuring the Performance of MFIs: An Application of Factor Analysis. In B. Balkenhol (Ed.), Microfinance and Public Policy (pp. 153-170). London: Palgrave Macmillan UK. http://doi.org/10.1007/978-0-230-30002-6_9

Macchiavello, E. (2012). Microfinance Regulation and Supervision: a multi-faced prism of structures, levels and issues. NYU Journal of Law and Business, 9(125), 125-197.

Mallick, D. (2013). How Effective is a Big Push to the Small? Evidence from a QuasiExperiment. World Development, Vol. 41, pp. 168-182. http://dx.doi.org/10.1016/j.worlddev.2012.05.021

Marakkath, N. (2014). Sustainability of Indian Microfinance Institutions: A Mixed Methods Approach. India Studies in Business and Economics. ISBN 978-81-322-1628-5 ISBN 978-81-322-1629-2 (eBook) DOI 10.1007/978-81-322-1629-2.

Marconi, M. de A.; \& Lakatos, E. M. (2003). Fundamentos de metodologia científica. - 5. ed. - São Paulo: Atlas.

Martins, G. de A. (2014). Estatística Geral e Aplicada - 5a Ed. - São Paulo: Atlas.

Martins, E., Diniz, J. A., \& Miranda, G. J. (2012). Análise avançada das demonstrações contábeis: uma abordagem crítica. Sao Paulo: Atlas.

Martins, E., Miranda, G. J., \& Diniz, J. A. (2014). Análise didática das demonstrações contábeis. Sao Paulo: Atlas.

Martins, G. de A. \& Theóphilo, C. R. (2009). Metodologia da investigação científica para Ciências Sociais Aplicadas - 2a ed. - ed. São Paulo: Atlas.

Martins, P. H., Winograd, A., \& Salles, R. C. (2002). Manual de Regulamentação das 
Microfinanças: Programa de Desenvolvimento Institucional. Rio de Janeiro: BNDES.

Matarazzo, D. C. (2008). Análise financeira de balanços: abordagem básica e gerencial (6a ed.). Sao Paulo: Atlas.

Meagher, P. (2002). Microfinance regulation in developing countries: a comparative review of current practice. Retrieved from: http://www.ppaf.org.pk $/ \mathrm{km} / \mathrm{pdf} /$ Regulation\% $\% 20$ $\% 20$ Review\%20across\%20countries.pdf

Mersland, R., Randøy, T., \& Strøm, R. Ø. (2011). The impact of international influence on microbanks' performance: A global survey. International Business Review, 20(2), 163176. http://doi.org/10.1016/j.ibusrev.2010.07.006

Mersland, R., \& Strøm, R. Ø. (2008). Performance and trade-offs in Microfinance Organisations-Does ownership matter? Journal of International Development, 20(5), 598-612. http://doi.org/10.1002/jid.1432

Mersland, R., \& Strøm, R. Ø. (2009). Performance and governance in microfinance institutions. Journal of Banking \& Finance, 33(4), 662-669. http://doi.org/10.1016/j.jbankfin.2008.11.009

Mersland, R., \& Strøm, R. Ø. (2010). Microfinance Mission Drift? World Development, 38(1), 28-36. http://doi.org/10.1016/j.worlddev.2009.05.006

Mersland, R., \& Urgeghe, L. (2011). Performance and international investments in microfinance institutions. CEB Working Paper, 32(0), 1-30.

Meyer, R. L. (2002). The demand for flexible microfinance products: lessons from Bangladesh. Journal of International Development, 14(3), 351-368. http://doi.org/10.1002/jid.884

Miguel, A. C. (2012). Microcrédito no Brasil: uma agenda de política pública para o mercado de microfinanças. REDD - Revista Espaço de Diálogo e Desconexão, 4(2), 1-23.

Montgomery, H., \& Weiss, J. (2011). Can Commercially-oriented Microfinance Help Meet the Millennium Development Goals? Evidence from Pakistan. World Development, 39(1), 87-109. http://doi.org/10.1016/j.worlddev.2010.09.001

Morduch, J. (1999). The Microfinance Promise. Journal of Economic Literature. Vol. XXXVII, pp. 1569-1614. http://www.jstor.org

Morduch, J. (2000). The Microfinance Schism. World Development, 28(4), 617-629. http://doi.org/10.1016/S0305-750X(99)00151-5

Navajas, S., Schreiner, M., Meyer, R. L., Gonzalez-Vega, C., \& Rodriguez-Meza, J. (2000). Microcredit and the Poorest of the Poor: Theory and Evidence from Bolivia. World Development, 28(2), 333-346. http://doi.org/10.1016/S0305-750X(99)00121-7

Neri, M., \& Medrado, A. (2010). Experimentando Microcrédito: uma análise de impacto do Crediamigo no acesso a crédito. Documentos Técnico-Cientificos, 41(1), 133-154. Retrieved from http://www.cps.fgv.br/ibrecps/clippings/mc1037.pdf 
North, D. C. (1990). Institutions, Institutional Change and Economic Performance. Cambridge: Cambridge University Press.

Nurmakhanova, M., Kretzschmar, G., \& Fedhila, H. (2015). Trade-off between financial sustainability and outreach of microfinance institutions. Eurasian Economic Review, 5(2), 231-250. DOI 10.1007/s40822-015-0016-7

Ojong, N. (2014). Credit unions as conduits for microfinance delivery in Cameroon. Annals of Public and Cooperative Economics, 85(2), 287-304. http://doi.org/10.1111/apce.12041

Pati, A. P. (2012). Regulation versus outreach and sustainability: a study of the performance of microfinance institutions in India. The IUP Journal of Bank Management, XI(4), 4156. Retrieved from http://ideas.repec.org/a/icf/icfjbm/v11y2012i4p41-56.html

Pereira, A. da C. (2007). Programa Nacional de Microcrédito Produtivo Orientado (PNMPO): descrição, resultados e perspectivas. In VI Seminário Banco Central sobre Microfinanças (pp. 1-21). Porto Alegre: Banco Central do Brasil.

Pinheiro, M. A. H. (2008). Cooperativas de Crédito História da evolução normativa no Brasil. Retrieved from http://www.bcb.gov.br/htms/public/microcredito/livro_cooperativas_credito.pdf

Pinho, D. B. (1982). O pensamento cooperativo e o cooperativismo brasileiro: Manual do cooperativismo. São Paulo: Brascoop/CNPq, 1

Pinho, D. B. (2001). Cooperativismo: Fundamentos Doutrinários e Teóricos, In: Educação Cooperativista (Organizador Ralph Panzutti). Coleção Estudo e Pesquisa. São Paulo: OCESP/SESCOOP-SP, $\mathrm{n}^{\mathrm{o}} 3$.

Pinho, D. B. (2004). O cooperativismo no Brasil: da vertente pioneira à vertente solidária. São Paulo: Saraiva.

Pohlmann, M. C., \& Alves, F. J. dos S. (2012). Regulamentação. In A. B. Lopes \& S. de Iudícibus (Eds.), Teoria avançada da contabilidade (2a ed., pp. 232-260). São Paulo: Atlas.

Posner, R. A. (1974). Theories of Economic Regulation. The Bell Journal of Economics and Management Science, 5(2), 335. http://doi.org/10.2307/3003113

Putnam, R. D. (1997). Comunidade e democracia: a experiência da Itália moderna. Rio de Janeiro: Fundação Getúlio Vargas.

Quayes, S. (2012). Depth of outreach and financial sustainability of microfinance institutions. Applied Economics, 44(26), 3421-3433. http://doi.org/10.1080/00036846.2011.577016

Railienè, G., \& Sinevičienè, L. (2015). Performance Valuation of Credit Unions Having Social and Self-sustaining Aim. Procedia-Social and Behavioral Sciences, 213, 423-429. http://www.sciencedirect.com/science/article/pii/S1877042815059169.

Robinson, M. S. (2001). The microfinance revolution: sustainable finance for the poor. Washington D. C.: International Bank for Reconstruction and Development/The World Bank. 
Rock, R., Otero, M., \& Saltzman, S. (1998). Principles and practices of microfinance governance. Development Alternatives, Incorporated.

http://www.ruralfinanceandinvestment.org/sites/default/files/1124710694929_Principles _MF_governance_summary.pdf

Rosales, R. (2000). Marco Jurídico para as instituições de microcrédito. In Seminário Internacional BNDES Microfinanças (pp. 1-20). Rio de Janeiro: BNDES.

Rosenberg, R. (2009). Measuring Results of Microfinance Institutions Minimum Indicators that Donors and Investors Should Trac.pdf. CGAP Technical Guide, (June), 1-32.

Sampaio, P. S. (2014). Microcrédito, desenvolvimento e superação da pobreza: uma análise jurídica do Programa Nacional de Microcrédito Produtivo Orientado. (Dissertação de mestrado). Curso de PósGraduação em Direito. Universidade de Brasília.

Schmidt, R. H. (2010). Microfinance, commercialization and ethics. Poverty \& Public Policy, 2(1), 99-137.

https://www.researchgate.net/profile/Reinhard_Schmidt/publication/46555104_Microfin ance_Commercialization_and_Ethics/links/0c96051dd8afb5815c000000.pdf

Schreiner, M \& Yaron, J. (1999). The Subsidy Dependence Index and Recent Attempts to Adjust It Microfinance Risk Management. In: Savings and Development, Vol. 23, No. 4, pp.375-405. Retrieved from http://microfinance.com/English/Papers/SDI_and_Adjustments.pdf

Schroder, M. (2005). Finanças, comunidades e inovações: organizações financeiras da agricultura familiar-o Sistema Cresol (1995-2003). (Tese de doutorado), Universidade Estadual de Campinas (UNICAMP). Instituto de Economia.

Scott, W. R. (2012). Financial accounting theory (6th ed.). Toronto: Pearson Prentice Hall.

Sekhon, J. S. \& Titiunik, R. (2012). When natural experiments are neither natural nor experiments. American Political Science Review. Vol. 106, No. 1.

Servin, R., Lensink, R., \& Van den Berg, M. (2012). Ownership and technical efficiency of microfinance institutions: Empirical evidence from Latin America. Journal of Banking and Finance, 36(7), 2136-2144. http://doi.org/10.1016/j.jbankfin.2012.03.018

Shadish, W. E., Cook, T. D., \& Campbell, D. T. (2002). Experimental and QuasiExperimental Designs for Generalized Causal Inference. Boston: Houghton Mifflin. Retrieved from http://impact.cgiar.org/pdf/147.pdf

Silva, R. V. da. (2012). Evolution and Impact of the Legal and Regulatory Framework on Microfinance in Brazil. University of Glasgow.

Simon, H. A. (1955). A Behavioral Model of Rational Choice. The Quarterly Journal of Economics, Vol. 69, No. 1. (Feb., 1955), pp. 99-118. Retrieved from http://www.jstor.org/stable/1884852?seq=1\#page_scan_tab_contents

Sinha, F. (2006). Social Rating and Social Performance Reporting in Microfinance Towards a Common Framework. The SEEP Network for the Argidius Foundation. Retrieved from https://www.shareweb.ch/site/EI/Documents/FSD/Topics/Social\%20Performance\%20M 
ainstreaming/Social\%20Rating\%20and\%20Social\%20Performance\%20Reporting\%20in $\% 20$ Microfinance $\% 20-\% 20$ Towards $\% 20 a \% 20$ Common\%20Framework\%20$\% 202006(\mathrm{en}) . \mathrm{pdf}$

Sinha, F., \& Brar, A. (2005). Can MFIs achieve the double bottom line? Gurgaon, India. Retrieved from http://www.m-cril.com/BackEnd/ModulesFiles/Publication/Technical Note 3 - Can MFIs Achieve the Double Bottom Line.pdf

Soares, M. M., \& Melo Sobrinho, A. D. (2008). Microfinanças O Papel do Banco Central do Brasil e a Importância do Cooperativismo de Crédito (2a ed.). Banco Central do Brasil.

Souza, C. (2006). Políticas públicas: uma revisão da literatura. Sociologias, 8(16), 20-45. http://doi.org/10.1590/S1517-45222006000200003

SPE. (2012). Secretaria de Política Econômica. Relatório de Gestão do Exercício de 2011. Brasília: Ministério da Fazenda. Retrieved from http://fazenda.gov.br/acesso-ainformacao/copy_of_auditorias/secretaria-da-receita-federal-do-brasil-rfb/relatorio-degestao-2011.pdf

SPE. (2013). Secretaria de Política Econômica. Relatório de Gestão do Exercício de 2012. Brasília: Ministério da Fazenda. Retrieved from http://fazenda.gov.br/acesso-ainformacao/copy_of_auditorias/secretaria-da-receita-federal-do-brasil-rfb/relatorio-degestao-2012.pdf

SPE. (2013a). Secretaria de Política Econômica. Botetim Programa CRESCER. Brasília: Ministério da Fazenda. Retrieved from http://www.spe.fazenda.gov.br/assuntos/politicaagricola-e-meio-ambiente/inclusao-produtiva/boletim-programa-crescer-2013

SPE. (2014). Secretaria de Política Econômica. Relatório de Gestão do Exercício de 2013. Brasília: Ministério da Fazenda. Retrieved from http://fazenda.gov.br/acesso-ainformacao/copy_of_auditorias/secretaria-da-receita-federal-do-brasil-rfb/relatorio-degestao-2013.pdf

Staschen, S. (1999). Regulation and Supervision of Microfinance Institutions: state of Knowledge. GTZ, Eschborn. Retrieved from http://www.freewebs.com/staschen/FINANZSYSTEME_Regulierung_State_of_Knowle dge_1999e.pdf

Stigler, G. J. (1971). The theory of economic regulation. The Bell Journal of Economics and Management Science, 3-21.

Stiglitz, J. E. (1989). The Economic Role of the State. In A. Heertje (Ed.), The Economic Role of the State (pp. 9-85). Basil Blackwell: Oxford.

Stiglitz, J. E. (1993). The Role of the State in financial markets. In World Bank's Annual Bank Conference on Development Economics. Washington D. C.: World Bank.

Stiglitz, J. E., \& Walsh, C. E. (2003). Introdução à microeconomia (3rd ed.). Rio de Janeiro: Campus.

Stiglitz, J. E., \& Weiss, A. (1981). Credit Rationing in Markets with Rationing Credit Information Imperfect. The American Economic Review, 71(3), 393-410. 
Townsend, R. \& Yaron, J. (2001) The Credit Risk Contingency System of an Asian Development Bank, International Monetary Fund Working Paper 01 (108), IMF, Washington, DC.

Trevisan, A. P., \& Van Bellen, H. M. (2008). Avaliação de políticas públicas: uma revisão teórica de um campo em construção. Revista de Administração Pública, 42(3), 529-550. http://doi.org/10.1590/S0034-76122008000300005

Trujillo, V., Rodriguez-Lopez, F., \& Muriel-Patino, V. (2014). Microfinance Regulation and Market Development in Latin America. The B.E. Journal of Economic Analysis \& Policy, 14(4), 1615-1644. http://doi.org/10.1515/bejeap-2013-0145

Tulchin, D. (2004). Microfinance \& the Double Bottom Line: Measuring social return for the microfinance industry \& microcredit with education programs. In BYU - 7th Annual MicroEnterprise Conference (Vol. 1, pp. 1-13). Provo, UT: Brigham Young University.

Van Greuning, H., Gallardo, J., \& Randhawa, B. (1998). A framework for regulating microfinance institutions. Paper n. 2061 (Vol. 18). Washington D. C.

Vanroose, A., \& D'Espallier, B. (2013). Do microfinance institutions accomplish their mission? Evidence from the relationship between traditional financial sector development and microfinance institutions' outreach and performance. Applied Economics, 45(15), 1965-1982. http://doi.org/10.1080/00036846.2011.641932

Vogel, R. C., Gomez, A., \& Fitzgerald, T. (1999). Regulation and supervision of microfinance: a conceptual framework. Micro Enterprise Best Practices.

Von Pischke, J. D. (1996). Measuring the trade-off between outreach and sustainability of microenterprise lenders. Journal of International Development, 8(2), 225-239. http://doi.org/10.1002/(SICI)1099-1328(199603)8:2<225::AID-JID370>3.0.CO;2-6

Ward, A. M., \& McKillop, D. G. (2005). An investigation into the link between UK credit union characteristics, location and their success. Annals of Public and Cooperative Economics, 76(3), 461-489. https://www.researchgate.net/profile/AnneMarie_Ward/publication/4732720_An_Investigation_into_the_Link_between_UK_Credi t_Union_Characteristics_Location_and_their_Success/links $/ 0 \overline{2}$ bfe $5 \overline{12} 2338 \mathrm{fb} 7 \overline{\mathrm{ec}} 5000000$ .pdf

Williamson, O. E. (1985). The Economic Intstitutions of Capitalism. New York: The Free Press.

Woller, G. (2002). From market failure to marketing failure: market orientation as the key to deep outreach in microfinance. Journal of International Development, 14(3), 305-324. http://doi.org/10.1002/jid.883

Wooldridge, J. M., (2010). Econometric Analysis of Cross Section and Panel Data, 2nd Edition. MIT Press: Cambridge, MA.

Yunus, M. (2010). Um mundo sem pobreza: a empresa social e o futuro do capitalismo. São Paulo: Editora Ática.

Zancanella, J. C., Oliveira, A. R. de, Cunha, N. R. da S., \& Lima, A. A. T. F. C. de. (2010). 
Avaliação do processo de implementação do Programa Nacional de Microcrédito Produtivo Orientado (PNMPO), em Minas Gerais, na percepção dos dirigentes das instituições habilitadas. $A P G S, 2(1), 86-108$.

Zouain, D. M., \& Barone, F. M. (2007). Excertos sobre política pública de acesso ao crédito como ferramenta de combate à pobreza e inclusão social: o microcrédito na era FHC. Revista de Administração Pública, 41(2), 369-380. http://doi.org/10.1590/S003476122007000200010

Sites:

www.bancoamazonia.com.br/index.php/governo/microcredito

www.bcb.org.br

www.bndes.gov.br

www.cerise-microfinance.org

www.objetivosdomilenio.org

www.planalto.gov.br

www.portalmte.gov.br

www.themix.org

www.woccu.org 


\section{APÊNDICES}

\subsection{APÊNDICE A: Valor total dos contratos ativos (em R\$ bilhões) - 2008 a 2014}

(dados trimestrais)

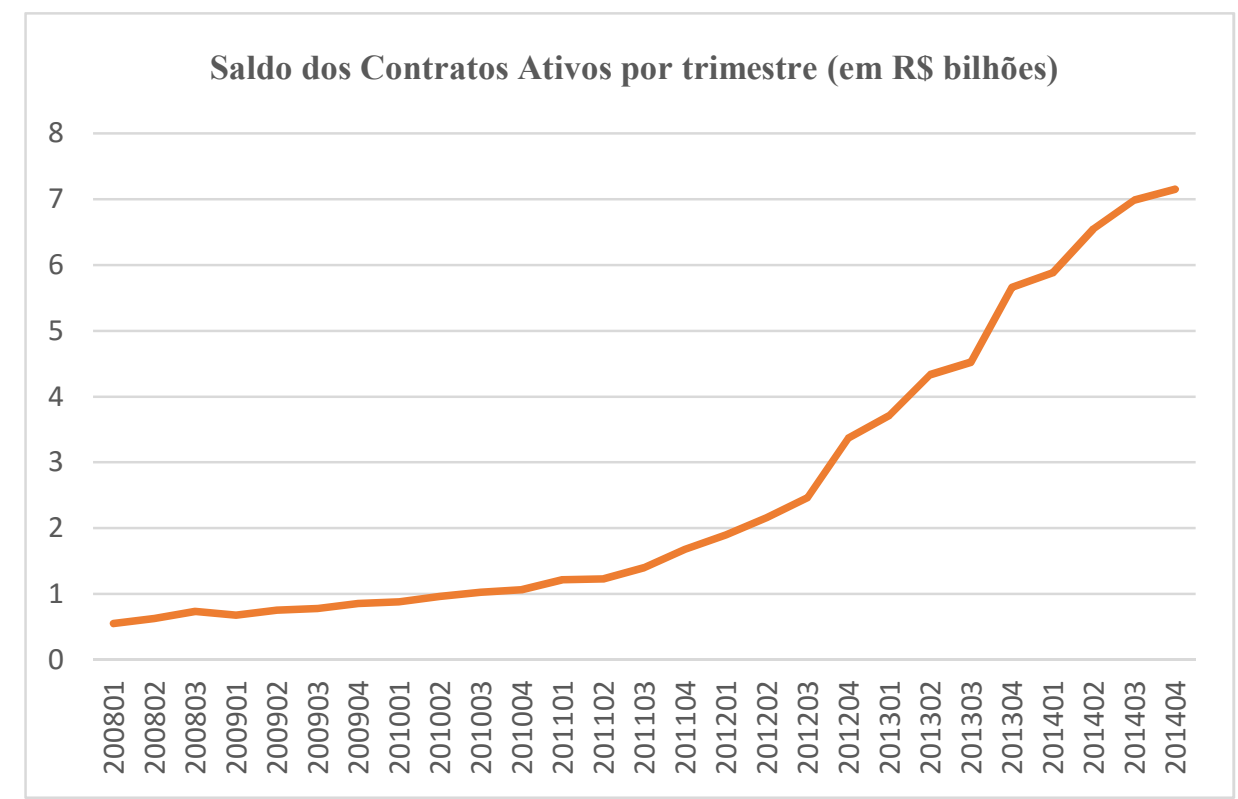

Figura 27: Valor total dos contratos ativos (em R\$ bilhões) - 2008 a 2014 (dados trimestrais) Fonte: Elaboração própria com base nos dados do MTE, 2015.

Nota: $\mathrm{O}$ ano de 2008 está em quadrimestre.

\subsection{APÊNDICE B: Quantidade de contratos ativos (em milhões) - 2008 a 2014 (dados trimestrais)}

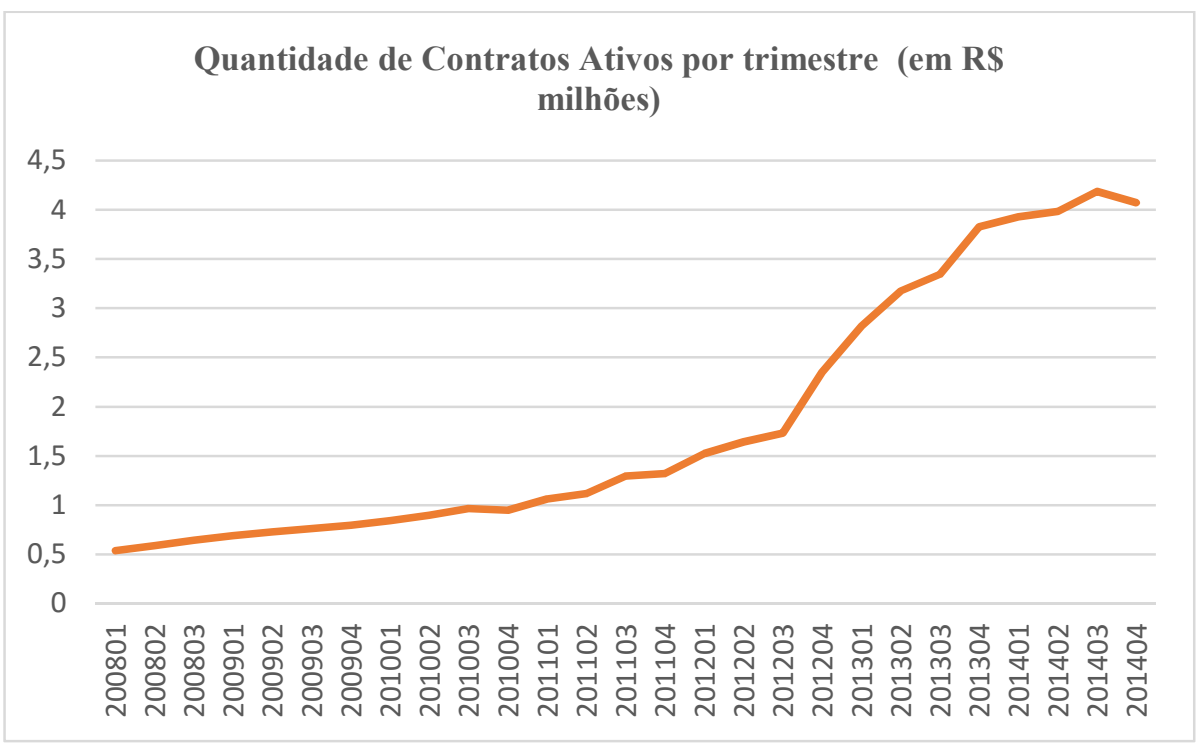

Figura 28: Quantidade de contratos ativos (em milhões) - 2008 a 2014 (dados trimestrais) Fonte: Elaboração própria com base nos dados do MTE, 2015.

Nota: O ano de 2008 está em quadrimestre. 


\subsection{APÊNDICE C: Quantidade de clientes ativos (em R\$ milhões) - 2008 a 2014}

\section{(dados trimestrais)}

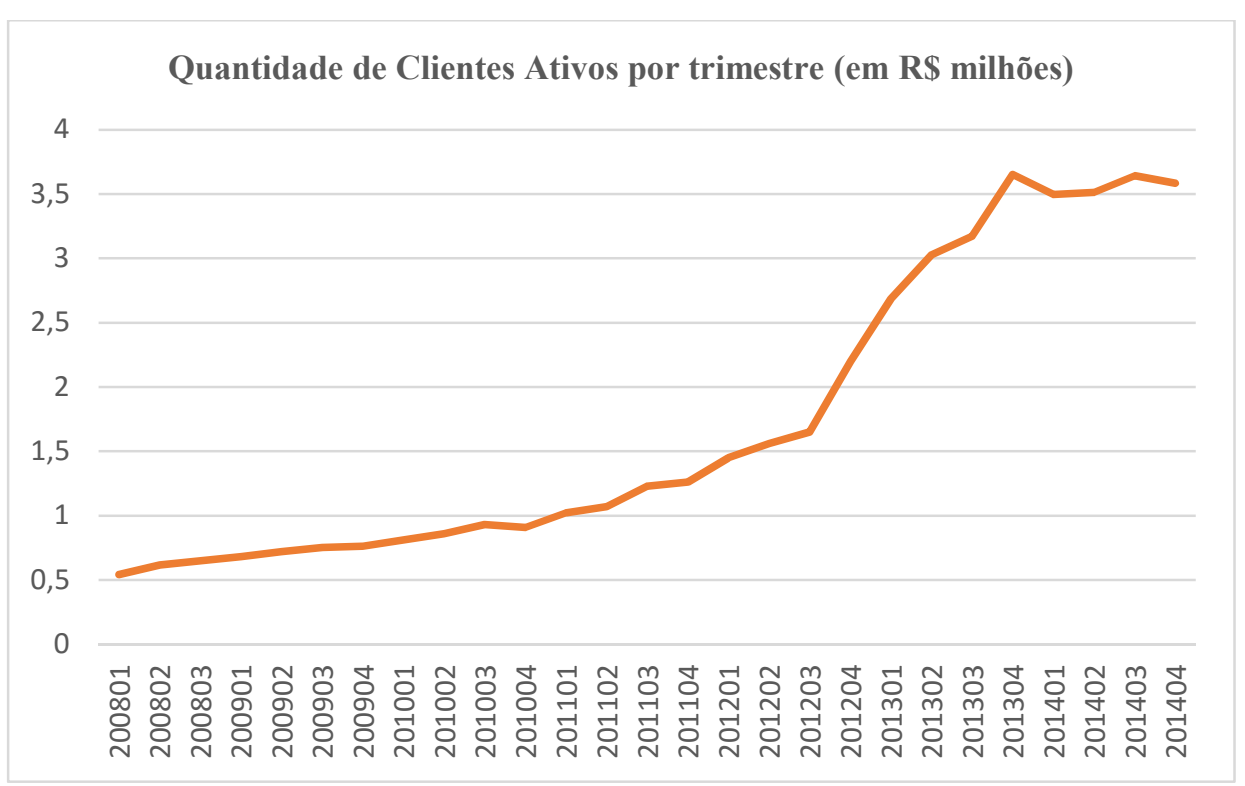

Figura 29: Quantidade de clientes ativos (em R\$ milhões) - 2008 a 2014 (dados trimestrais)

Fonte: Elaboração própria com base nos dados do MTE, 2015.

Nota: O ano de 2008 está em quadrimestre.

\subsection{APÊNDICE D: Valor total dos contratos realizados (em R\$ bilhões) - 2008 a 2014 (dados trimestrais)}

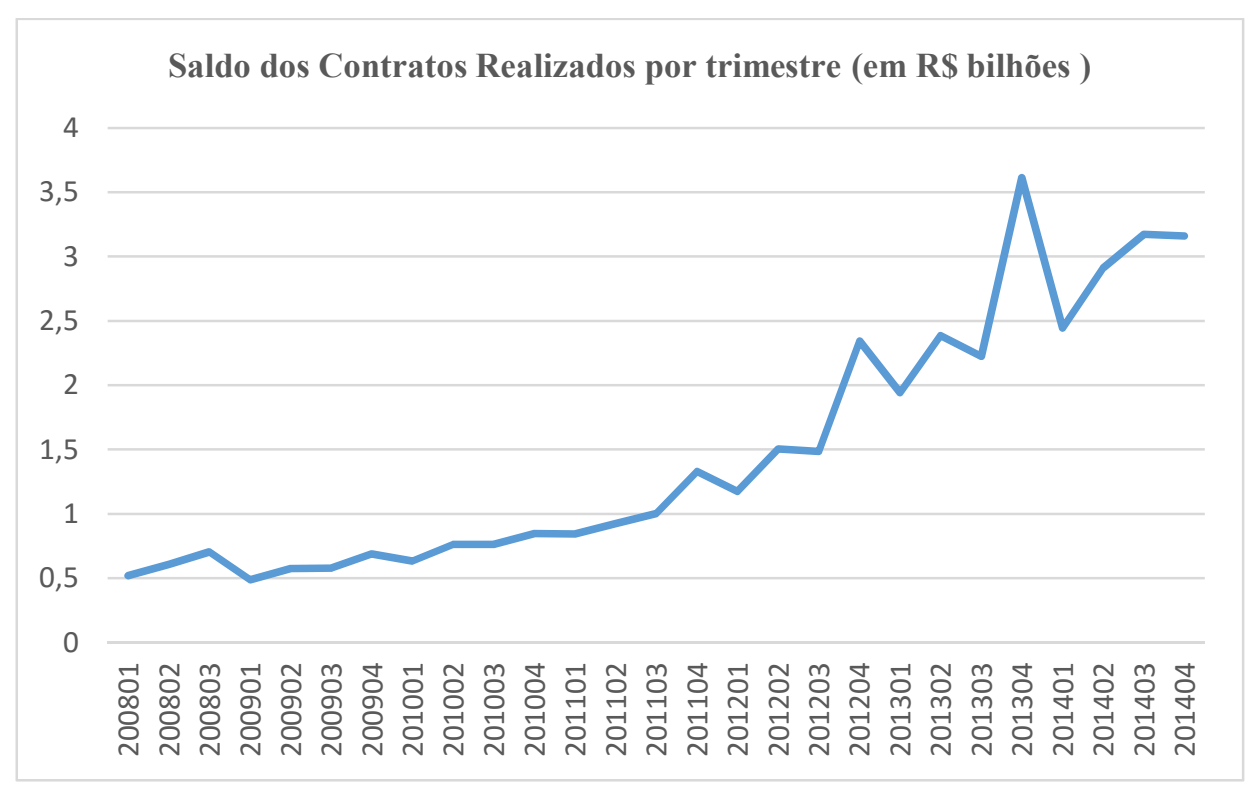

Figura 30: Valor total dos contratos realizados (em R \$ bilhões) - 2008 a 2014 (dados trimestrais) Fonte: Elaboração própria com base nos dados do MTE, 2015.

Nota: O ano de 2008 está em quadrimestre. 
7.5 APÊNDICE E: Quantidade de contratos realizados (em milhões) - 2008 a 2014 (dados trimestrais)

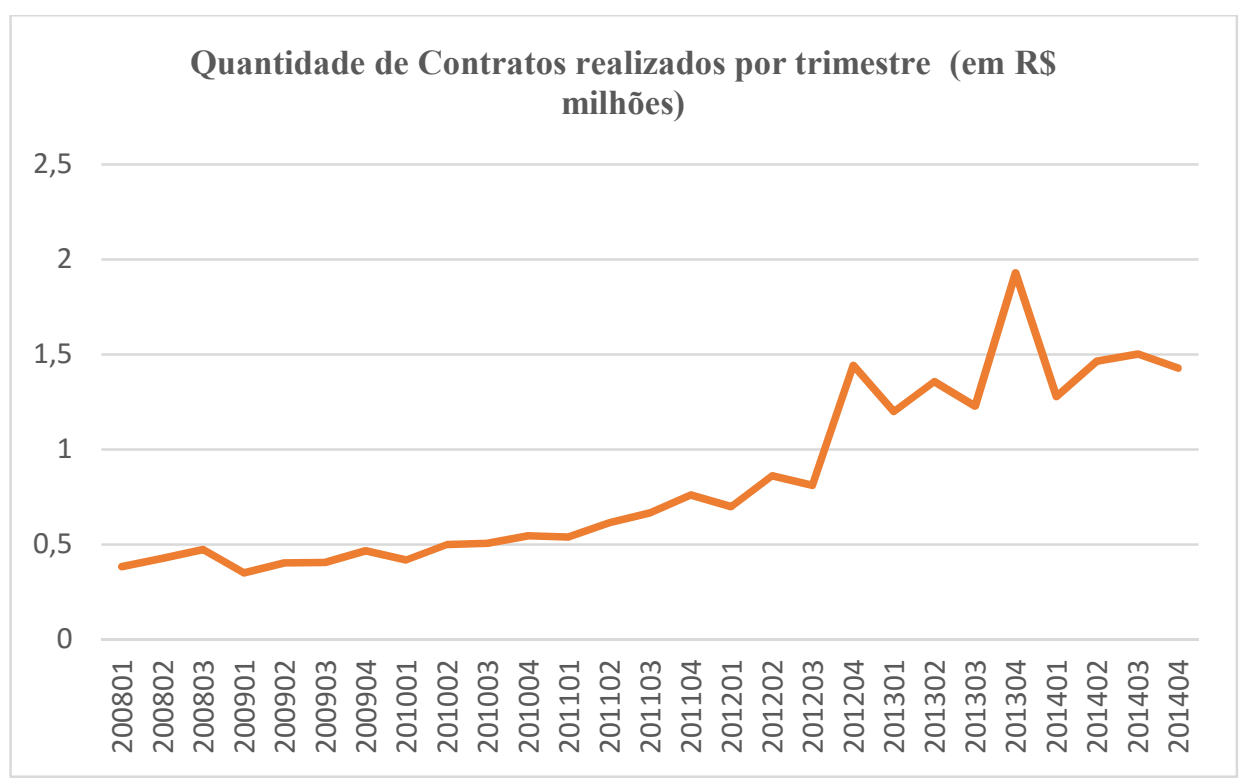

Figura 31: Quantidade de contratos realizados (em milhões) - 2008 a 2014 (dados trimestrais) Fonte: Elaboração própria com base nos dados do MTE, 2015.

Nota: O ano de 2008 está em quadrimestre.

\subsection{APÊNDICE F: Quantidade de contratos realizados por clientes (em RS milhões) - 2008 a 2014 (dados trimestrais)}

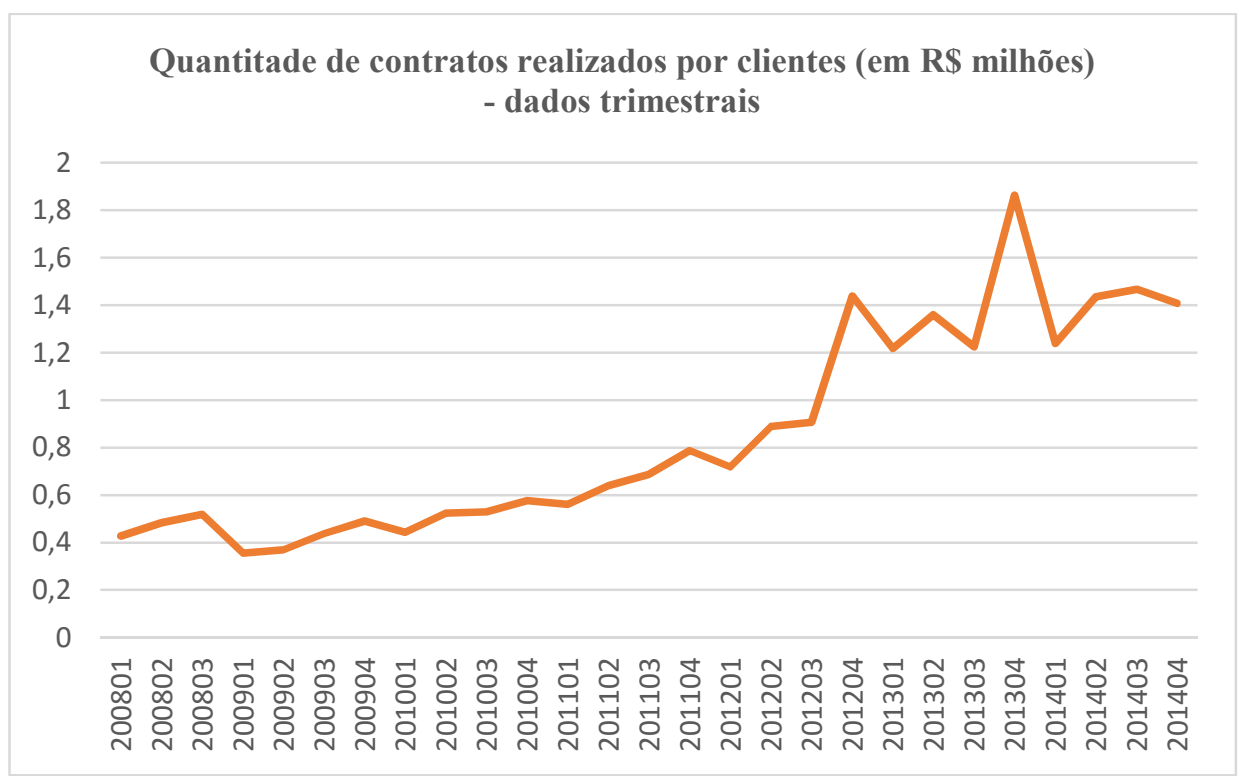

Figura 32: Quantidade de contratos realizados por clientes (em R \$ milhões) - 2008 a 2014 (dados trimestrais) Fonte: Elaboração própria com base nos dados do MTE, 2015.

Nota: $\mathrm{O}$ ano de 2008 está em quadrimestre. 


\subsection{APÊNDICE G: Valor dos contratos ativos - Bancos públicos - 2008 a 2014 (dados} trimestrais) - em R\$ milhões

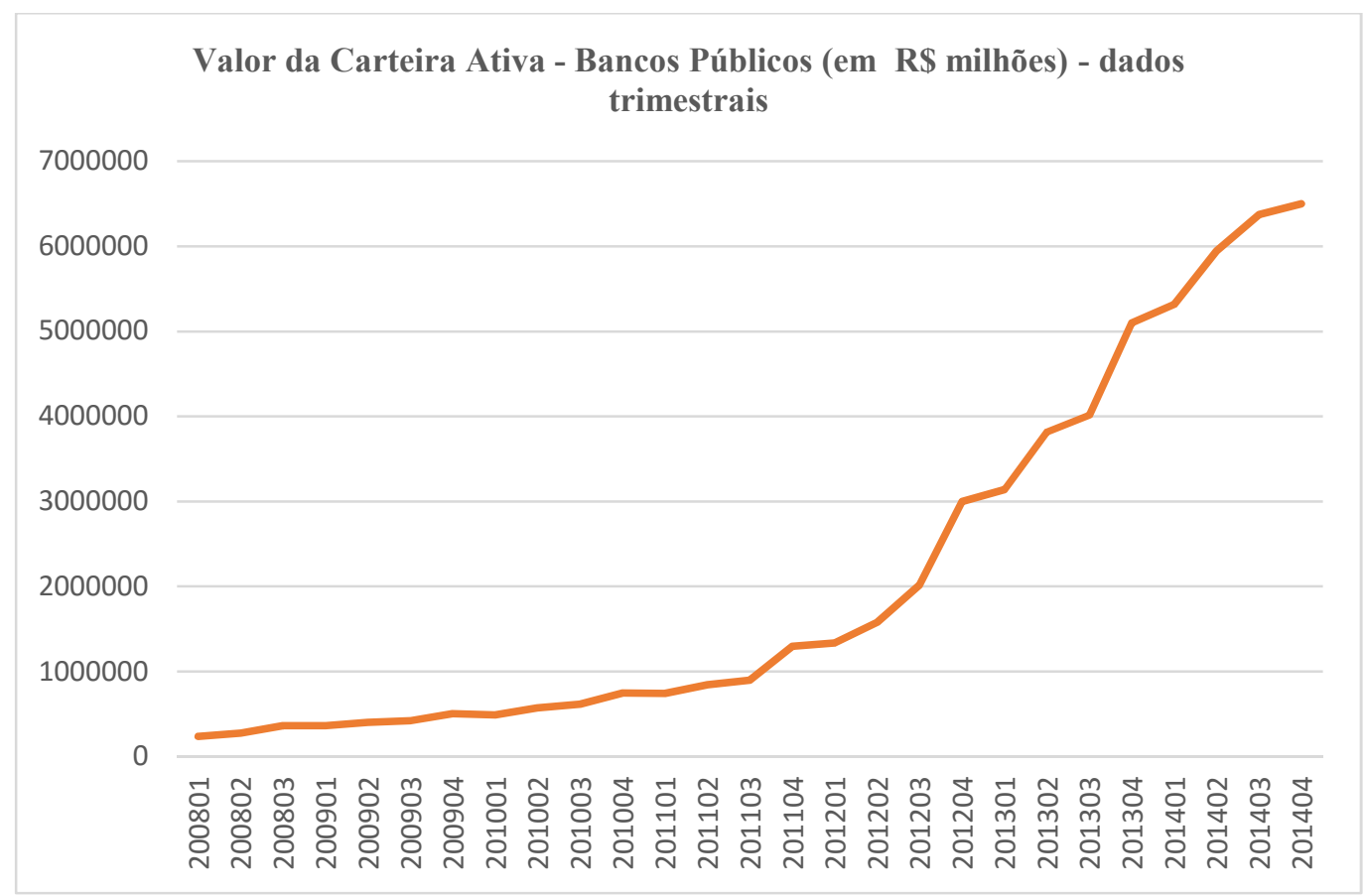

Figura 33: Valor dos contratos ativos bancos públicos - 2008 a 2014 (dados trimestrais) - em R \$ milhões Fonte: Elaboração própria com base nos dados do MTE, 2015.

Nota: O ano de 2008 está em quadrimestre.

\subsection{APÊNDICE H: Valor da Carteira Ativa - Cooperativas de Crédito (em R\$ milhões) - dados trimestrais - 2008 a 2014}

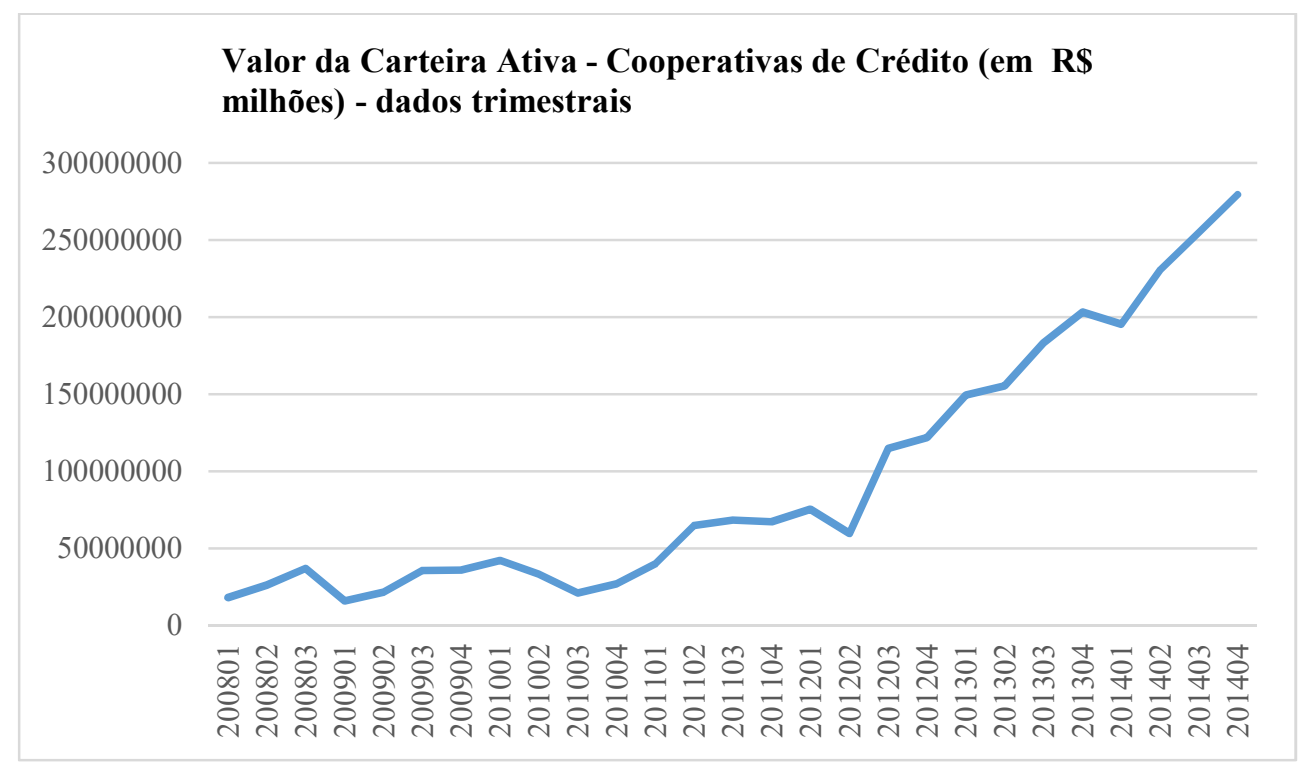

Figura 34: Valor da Carteira Ativa - Cooperativas de Crédito (em R\$ milhões) - dados trimestrais -2008 a 2014

Fonte: Elaboração própria com base nos dados do MTE, 2015.

Nota: $\mathrm{O}$ ano de 2008 está em quadrimestre. 


\subsection{APÊNDICE I: Valor da Carteira Ativa - OSCIPs (em R\$ milhões) - dados} trimestrais- 2008 a 2014

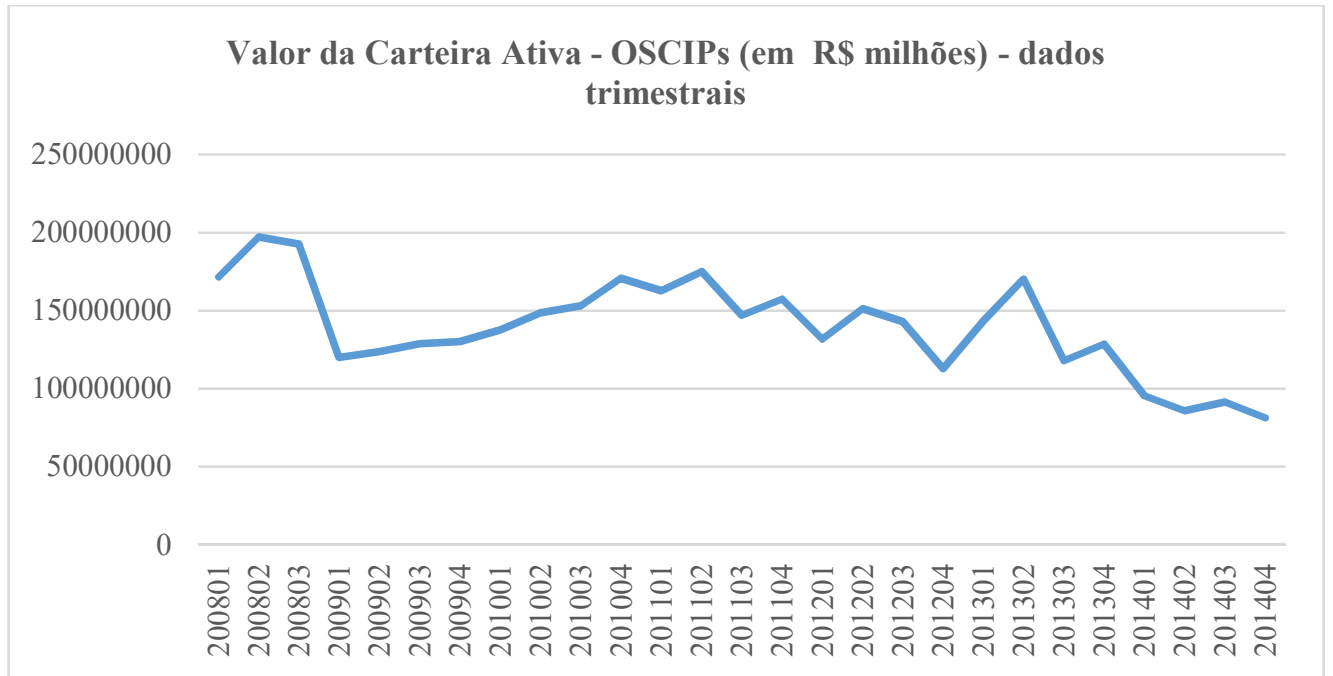

Figura 35: Valor da Carteira Ativa - OSCIPs (em R\$ milhões) - dados trimestrais-2008 a 2014 Fonte: Elaboração própria com base nos dados do MTE, 2015.

Nota: $\mathrm{O}$ ano de 2008 está em quadrimestre. 



\title{
7.10 APÊNDICE J: Termo de Consentimento Livre e Esclarecido (TCLE)
}

\author{
Q FEAUSP \\ UNIVERSIDADE DE SÃO PAULO \\ FACULDADE DE ECONOMIA, ADMINISTRAÇÃO E CONTABILIDADE \\ DEPARTAMENTO DE CONTABILIDADE E ATUÁRIA \\ PROGRAMA DE PÓS-GRADUAÇÃO EM CONTROLADORIA E CONTABILIDADE
}

\section{TERMO DE CONSENTIMENTO LIVRE E ESCLARECIDO}

$\mathrm{Eu}$, concordo em participar da pesquisa para a tese de doutorado intitulada: Efeitos da regulação do microcrédito no Brasil no desempenho financeiro e social das instituições, sob orientação do Professor Dr. Gerlando Lima e coorientação do prof. Dr. Lucas Barros. Declaro que, de livre e espontânea vontade responderei as perguntas da entrevista que será gravada, transcrita e analisada pela pesquisadora. Declaro também estar ciente que, durante a pesquisa, caso tenha dúvidas serei esclarecido(a), assim como terei a liberdade de me recusar a participar ou retirar meu consentimento em qualquer fase da pesquisa, sem penalização alguma. Declaro ainda que minha participação está livre de qualquer remuneração ou despesa. Vale ressaltar que as informações individuais da instituição serão tratadas de forma sigilosa e apenas as informações agregadas serão divulgadas.

Entrevistado (a)

Pesquisadora

Ana Lucia Carvalho Santos

Email: analuciafeausp@usp.br 


\section{11 APÊNDICE K: Roteiro de Entrevista}

1. Cargo/função do entrevistado.

2. Nome da Instituição.

3. Localização da Instituição (Cidade, Estado).

4. Ano de fundação/criação da instituição.

5. Tipo:
( ) OSCIP
( ) $\mathrm{SCM}$
( ) Banco Público
( ) Banco Privado
( ) Cooperativa de Crédito
( ) Crédito Mútuo
( ) Crédito Rural
( ) Coop. Central
( ) Banco Cooperativo
( ) Agência de Fomento
( ) Programa de Governo (Federal, Estadual, Municipal)

6. Qual o conceito de Microcrédito Produtivo Orientado (MPO) utilizado pela instituição?

7. Qual é a diferença, no entendimento da instituição, entre MPO e outras modalidades como crédito para microempreendedor, microcrédito rural, PRONAF etc.?

8. O microcrédito ofertado pela Instituição é exclusivamente urbano ou é também rural?

9. Origem dos recursos do MPO.
( ) Próprios
( ) FAT
( ) $2 \%$ dos depósitos à vista
( ) Agência de Fomento
( ) BNDES
( ) Outro Banco de Desenvolvimento
( ) Outra (especifique)

10. Metodologia adotada.

11. Garantias exigidas:
( ) Aval
( ) Fiança
( ) Aval solidário
( ) Garantia real (garantia com bens, penhor, alienação...)
( ) Outras. Especificar
( ) Não exige garantias

12. Modalidades de microcrédito (empréstimos, financiamentos, capital de giro, investimento etc.)

13. Taxa de juros de captação.

14. Taxa de juros da operação. 
15. Custo da operação.

16. Taxa de Abertura de Crédito (TAC).

17. Valor médio das operações.

18. Prazo médio concedido (meses).

19. Como é feita a análise de crédito?

20. Perfil dos clientes.

○ Formal/informal

- Gênero

- Atividades financiadas

21. Atores/organizações/parceiros envolvidos na operacionalização do MPO.

22. Como vê a participação do Estado na operacionalização do MPO?

23. O que mudou após as medidas adotadas em 2011 e regulamentadas em 2012 (Resoluções do Banco Central $\mathrm{n}^{\mathrm{o}}$ 4.000, de 2011 e $\mathrm{n}^{\mathrm{o}}$ 4.153/2012 que regulamentam a destinação de $2 \%$ dos depósitos à vista para o MPO, sendo que desses $2 \%$, no mínimo $80 \%$ têm que ser direcionado para o MPO, restando apenas $20 \%$ para o microcrédito de consumo)? (melhorou/piorou).

24. Qual foi o impacto da redução mandatória de custo do financiamento (redução da taxa de juros)?

25. Qual a importância do subsídio governamental? É fundamental?

26. O MPO é sustentável sem o subsídio do governo? Se não, poderá ser um dia?

27. Será que o estímulo à entrada mais forte dos bancos públicos no MPO prejudica as demais IMFs?

28. A exigência de aplicação dos $80 \%$ dos $2 \%$ dos depósitos à vista provoca um efeito do tipo 'crowding out' (substituição do microcrédito de consumo pelo produtivo)?

29. Facilidades e/ou entraves para operar o MPO.

30. Quais são as perspectivas para o MPO?

31. Quais são os efeitos das medidas sobre o desempenho financeiro (indicadores de rentabilidade, produtividade etc.) e social (número de mutuários atendidos, número de mulheres atendidas etc.)?

32. Que outra modalidade de crédito é mais comparável com o MPO, mas não sofreu mudança no período (2011 para cá), por exemplo, Pronaf?

33. Na sua opinião, quais instituições foram mais afetadas pelas medidas?

34. As mudanças afetaram a inadimplência para melhor ou para pior?

35. Quais seriam os melhores indicadores para um pesquisador olhar, se quiser avaliar o impacto do MPO e das mudanças de regulamentação no desempenho financeiro e social das Instituições? 